\title{
KIMBERLEY TROPICAL MONSOON RAINFORESTS OF WESTERN AUSTRALIA: PERSPECTIVES ON BIOLOGICAL DIVERSITY
}

\author{
Kevin F. Kenneally \\ School of Agriculture \& Environment, Faculty of Science \\ The University of Western Australia, MOO4, 35 Stirling Highway \\ Crawley, Western Australia 6009, AUSTRALIA \\ Nulungu Research Institute, Notre Dame University Australia, Broome, Western Australia, AUSTRALIA \\ Western Australian Herbarium, Department of Biodiversity \\ Conservation and Attractions (DBCA), Locked Bag 104, Bentley Delivery Centre, Western Australia 6983, AUSTRALIA \\ Western Australian Museum, Department of Terrestrial Zoology \\ 49 Kew St, Welshpool, Western Australia 6106, AUSTRALIA \\ kevin.kenneally@uwa.edu.au
}

ABSTRACT

There are more than 1,500 patches of monsoon rainforest, totaling 7,000 hectares, scattered across 170,000 square km of the tropical Kimberley region of Western Australia. They are small, isolated and embedded within a mosaic of mostly flammable eucalypt savanna woodlands. The status and condition of Kimberley monsoon rainforest biodiversity are assessed based on geographically comprehensive survey data from a total of 100 sites and opportunistic collecting in many others. Monsoon rainforests are rich in species not found in the region's other vegetation communities. Most rainforests and their associated faunal assemblages are not currently reserved and many of the survey sites were found to be severely disturbed by fire and introduced feral cattle. The disturbance impact of fires, introduced animals and weeds is shown to apply generally across the three major forms of land tenure operating in the Kimberley; namely, Aboriginal land (including Indigenous Protected Areas), Crown land (including pastoral leasehold), and national parks and reserves. The implications of these disturbance factors on the conservation and management practices of monsoon rainforest patches in the region are considered. It is concluded that conservation of patches requires active fire and feral animal management. Equally, however, the long-term genetic viability of these small scattered patches and populations requires effective conservation at the landscape scale. Mounting evidence of the Kimberley as a historical and significant center of refugia warrants action from scientists, governments, conservation agencies, Indigenous landholders as well as local communities to protect and conserve its unique biota and the processes responsible for generating and sustaining it.

\section{RESUMEN}

Existen más de 1,500 parches de selva monzónica, que comprenden 7,000 hectáreas, esparcidos a lo largo de 170,000 km cuadrados de la región tropical de Kimberley del Oeste de Australia. Son parches pequeños, aislados e insertados en un mosaico de bosque de sabana de eucalipto inflamable. El estado y las condiciones de la biodiversidad de la selva monzónica de Kimberley se estiman mediante el sondeo de datos geográficos obtenidos de un total de 100 sitios y de la obtención oportunista en otros casos. Las selvas monzónicas son ricas en especies que no se encuentran en otras comunidades vegetales. La mayoría de relaciones entre las selvas y su fauna asociada no se encuentran actualmente reservadas y se observó que muchos de los sitios de sondeo están afectados severamente por el fuego y el ganado salvaje. El impacto de las perturbaciones causadas por fuego, animales introducidos y malas hierbas parece aplicarse generalmente a lo largo de las tres principales formas de tenencia de tierras en Kimberley; concretamente, tierras aborígenes (incluyendo Áreas Indígenas Protegidas), tierras de la Corona (incluyendo alquileres pastorales), y parques nacionales y reservas. Se consideran las implicaciones de estos factores de perturbación en la conservación y prácticas de gestión de los parches de selva monzónica. Se ha concluido que la conservación de parches requiere la gestión de fuegos activos y de animales salvajes. Igualmente, sin embargo, la viabilidad genética a largo plazo de estos parches y poblaciones pequeños y dispersos requiere de una conservación efectiva a nivel de paisaje. La evidencia cada vez mayor de Kimberley como un centro histórico y significativo de refugio justifica la acción de científicos, gobiernos, agencias conservacionistas, terratenientes indígenas, así como las comunidades locales a proteger y conservar su biota extraordinaria y los procesos responsables para su producción y su mantenimiento.

KEY WORDS: Australian monsoon tropics; biodiversity conservation; rainforest floristics, traditional ecological knowledge, Aboriginal natural resource management; biological survey; feral cattle; fire regimes; weeds

\section{INTRODUCTION}

Tropical rainforests are among the most complex and species-rich ecosystems to have existed on the planet although they occupy only $5 \%$ of its land surface (Whitmore 1984). They are characterized by enormous numbers of species and life forms concentrated in relatively small areas. Such luxuriance can usually only be 
sustained by high rainfall and a tropical climate (Grainger 1980). Generally, rainforest canopies are so dense that very little solar radiation penetrates to the ground. As a consequence, a humid and relatively stable microclimate develops in the understory supporting and protecting a myriad of lifeforms. Various regeneration niches are created when fallen trees locally disrupt the integrity of the forest canopy.

Tropical forests store large amounts of carbon, but agreement is lacking on their net contribution to the terrestrial carbon balance. Researchers have discovered that tropical forests in South America, Africa and Asia (between $23.45^{\circ} \mathrm{N}$ and $23.45^{\circ}$, excluding Australia), that have until recently played a key role in absorbing greenhouse gases are now, as a result of disturbance releasing 425 teragrams of carbon annually. This is more than that generated by all the traffic in the United States (Baccini et al 2017). Their study measured the impact of disturbance and degradation, (the thinning of tree density and the culling of biodiversity below an apparently protected canopy), usually as a result of selective logging, fire, drought and hunting, that can reduce biomass by up to $75 \%$. They commented: "As always, trees are removing carbon from the atmosphere, but the volume of the forest is no longer enough to compensate for the losses. The region is not a sink anymore." The researchers concluded that the priority is to protect pristine forests with high carbon density. The most effective way of doing this, they said, was to support land rights for Indigenous people (Watts 2017).

Many rainforests and their associated faunal assemblages across northern Australia face environmental threats from intense wildfires, feral animals, introduced ants, weed invasion, disturbance to rainforest aquifers, climate change and the invasion by cane toads (Russell-Smith \& Bowman 1992a). Management and conservation of these remote and naturally fragmented patches of monsoon rainforest in the Kimberley region of Western Australia is not an easy task. Just recognizing their value in the landscape is not sufficient. They need legislative protection to ensure their conservation and survival. Using the "precautionary principle" we need to balance rainforest conservation with present and emerging uses in the Kimberley (Australian Government 2015a). Many fruit-eating birds and mammals are responsible for the movement of seeds between patches and they require many patches to maintain their populations. Consequently, every patch has value and we cannot afford to lose these "Jewels in the Crown" scattered throughout the savanna grasslands and woodlands that dominate the Kimberley landscape. Significantly, many plant species found in the Kimberley monsoon rainforests have been traditionally utilized by Aboriginal people of the Kimberley and by other cultures in southeast Asia for their food potential as well as the multiple pharmaceutical and medicinal compounds they contain. We have not yet investigated the potential that these plants may hold.

In this paper, I will review what we know of Kimberley monsoon rainforests and why we need to appreciate their value, not only to the biodiversity of northern Australia but also in terms of their conservation value, traditional use and cultural significance to Aboriginal people.

We now know that more than 1, 500 patches of monsoon rainforest totaling 7,000 hectares (ha) are scattered across 170, 000 square $\mathrm{km}$ of the northwest Kimberley region of Western Australia. They are small, isolated and embedded within a mosaic of mostly flammable Eucalyptus/Corymbia (Myrtaceae) dominated forest or woodland savanna (Fig. 1). They are effectively islands in a sea of savanna woodlands. The average patch has an area of less than four hectares, approximately 3\% exceed 20 ha with the largest being 200 ha. Even so, they are rich in species not found in the region's other vegetation communities. Of the 1,500 monsoon rainforest patches in the Kimberley less than 100 have been scientifically surveyed and documented. In order to fully understand the biodiversity of Kimberley monsoon rainforests it is critical that we survey and assemble more pieces of the jigsaw to fully appreciate their complex character.

\section{JUNGLE OR RAINFOREST?-CHANGES IN HUMAN PERCEPTION}

The terms jungle, jungle-like thickets, 'corridor' jungle, and miniature jungle were used in Australia by early explorers (Brockman 1880) and writers such as Ernestine Hill (1933) to describe dense, impenetrable vegetation in the Kimberley and northern Australia. More often than not the term was applied to the dense riparian vegetation growing along creeks and rivers, occasionally to mangroves and rarely to monsoon rainforest patches (Gardner 1944). 


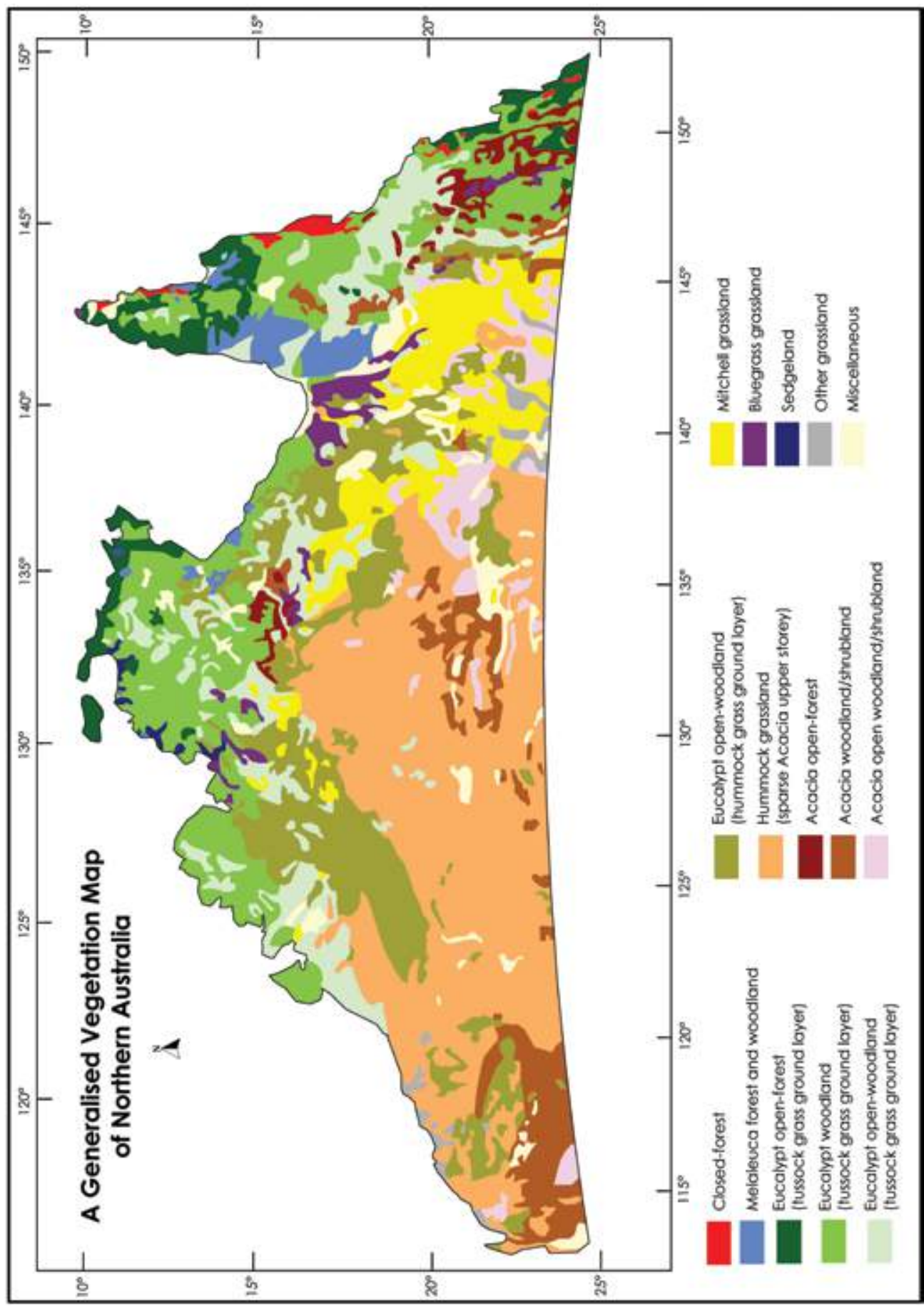

فํ. 
The word jungle conjures up images of Edgar Rice Burroughs' comic hero Tarzan swinging from vine to vine through dense and luxuriant vegetation surrounded by a host of exotic animals. The word jungle originates from Hindi jangal, from Sanskrit jāgala, meaning wilderness or uncultivated land, with the Anglo-Indian interpretation leading to its connotation as a dense tangled thicket (Zimmermann 1999). Mature evergreen rainforest is usually not difficult to penetrate (Richards 1952). However, where light penetrates the canopy the vegetation is sufficiently dense and impenetrable to hinder movement by humans, requiring travelers to cut their way through. In modern usage, the word rainforest has superseded jungle as a more specific and scientific term when referring to tropical forests, although the term jungle is still used. In scientific literature, the evergreen forest is referred to as tropical rainforest, a term introduced by Schimper (1903). The word jungle itself carries connotations of untamed and uncontrollable nature and isolation from civilization, along with emotions that evoke threat, powerlessness, disorientation and immobilization (Slater 2003)—something that those of us who have explored monsoon rainforest will attest to!

\section{TROPICAL MONSOON RAINFORESTS IN AUSTRALIA}

Rainforest is usually associated with the "evergreen" jungles of South America, Africa or southeast Asia, however, Australia has about 1.6 million ha of tropical rainforest and 0.5 million ha of temperate rainforest. As an indication of global modification to rainforest, an area greater than Australia's entire rainforest is cleared in the Amazon River Basin alone every year (McKenzie et al. 1991).

In reality, the tropical rainforest found across northern Australia corresponds to monsoon forest as defined by Schimper (1903), "as more or less leafless during the dry season, especially towards its termination, is tropophilous in character (adapted to a climate characterized by marked environmental changes), usually less lofty than rainforest, rich in woody lianes, rich in herbaceous, but poor in woody epiphytes." In northern Australia, the term includes semi-deciduous monsoon vine thickets that are distinguished from leafy "evergreen" forests (never deciduous) by becoming more or less leafless (deciduous or semi-deciduous) during the dry season and "raingreen" during the wet season.

Monsoon rainforest occurs as small, seasonally sparse, raingreen patches confined to gullies and scree slopes or behind coastal sand dunes. Many monsoon forests occur on sites with enhanced soil moisture (springs, seeps, creek lines, etc.) and in some cases, may be protected from fire by the rock or boulder fields on which they grow (Beard 1976). Their floristic relationships are with evergreen rainforest, although the distinctive structural features of the evergreen (or humid) rainforest are sparse or absent and annual herbs are present (McKenzie et al.1991).

Australia's monsoon rainforests are part of a great corridor of monsoon forests that extend through the areas of Australasia that have strong seasonally wet and dry climates. They are thought to be part of a formerly more widespread palaeotropical flora that has evolved through a series of marked paleoclimates, possibly through the inland adaption of littoral floras (McKenzie et al. 1991).

The vegetation in Kimberley monsoon rainforest patches can be classified structurally and floristically into three types which correspond to those defined by Webb (1959) for the lowland areas of the tropical rainforest region, (i.e. complex mesophyll monsoon forest, semi-evergreen mesophyll monsoon forest and deciduous monsoon vine thicket). They represent three structural levels controlled by availability of moisture.

Only three closed-canopy vegetation communities are found in the wet-dry tropics of Western Australia: monsoon rainforests, riparian stands that fringe watercourses and mangroves.

Scattered throughout the vast areas of savanna in the northwest Kimberley these small patches of monsoon rainforest have floristic affinities to humid rainforests of southeast Asia and northeast Queensland (Russell-Smith \& Lee 1992b). Large tracts of humid evergreen rainforest are now restricted to the northeast coast of Australia and are separated from the monsoon forests of Western Australia and the Northern Territory by the Gulf of Carpentaria and the arid grasslands of the Barkly Tablelands (Bowman et al. 1991) (Figs. 2 \& 3).

Webb and Tracey (1981) point out that Australian rainforests have very few species in common with the adjacent sclerophyll vegetation, and that they are distinguished from other closed forests by the prominence of 


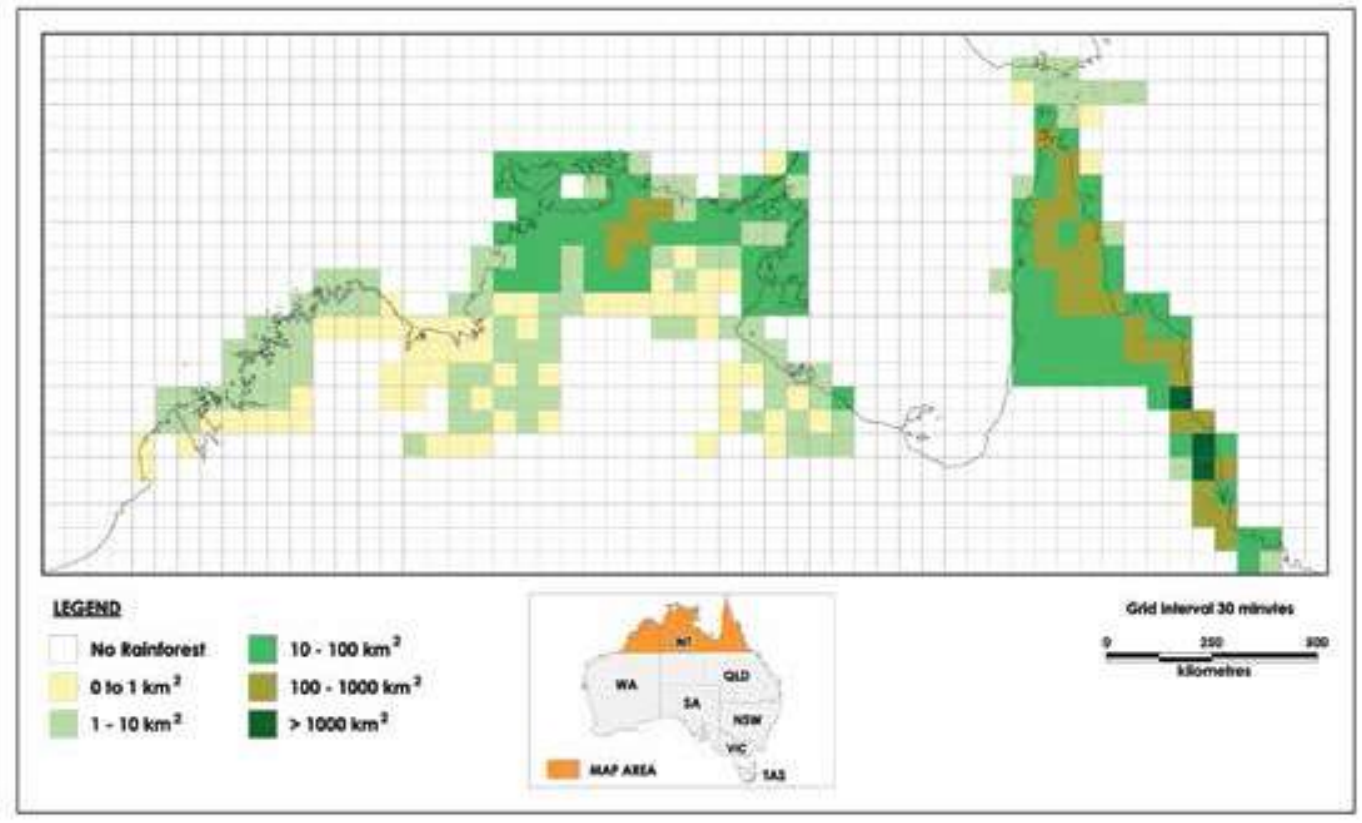

Fig. 2. Distribution and size of monsoon rainforest patches (Russell-Smith \& Stanton 2002) across Northern Australia (reproduced with permission from Savanna Explorer www.savanna.org.au). Rainforests do not dominate the landscape in Northern Australia, but some areas do have patches of "monsoon" rainforest with extensive evergreen rainforest being found in northeast Queensland.

trees, shrubs and vines bearing fleshy fruits, epiphytes, lianas (woody vines), aerial roots and buttress tree trunks.

The high diversity of plant species in the Kimberley monsoon rainforests results from very high numbers of families and genera, each of which is represented by one or several species (Kenneally et al. 1991). This is a contributing factor in the high level of complexity found in this vegetation type. Many of the families and genera of plants found here do not occur outside these rainforest patches, making their conservation a high priority.

These raingreen monsoon rainforests are characterized as much by their relatively high proportion of vagile, cosmopolitan genera as by their largely deciduous canopy. Deciduous trees predominate in most of these forests, and during the dry season a leafless period occurs. Because trees lose moisture through their leaves, the shedding of leaves allows trees to conserve water during the dry season. The deciduous trees open up the canopy layer, enabling sunlight to reach the ground and facilitate the growth of a dense understory. Studies of litter fall in monsoon rainforests and mangroves at Mitchell Plateau have shown that there are pronounced seasonal variations in leaf fall, which was monophasic at Walsh Point rainforest patch (April-July) and biphasic at Lone Dingo rainforest patch (April-July; September-November). However, over the entire year adjacent mangroves had the highest litter fall of all sites sampled (Bradley et al. 1987).

\section{ABORIGINAL TRADITIONAL KNOWLEDGE OF KIMBERLEY MONSOON RAINFORESTS}

Aboriginal occupation of the Kimberley currently is known to extend back ca. 47-50 ka BP (O'Connor 1995; Balme 2000; O'Connor \& Veth 2006). Recent research suggests that Aboriginal people had a particularly complex set of people-plant relationships (Fig. 4). Significantly, Kimberley rock art stands out globally in having an enormous body of direct and indirect depictions of plants, including grasses, trees and yams as well as plantbased material culture such as digging sticks (Ouzman et al. 2017; Veth et al. 2016). Crawford (1982) and 


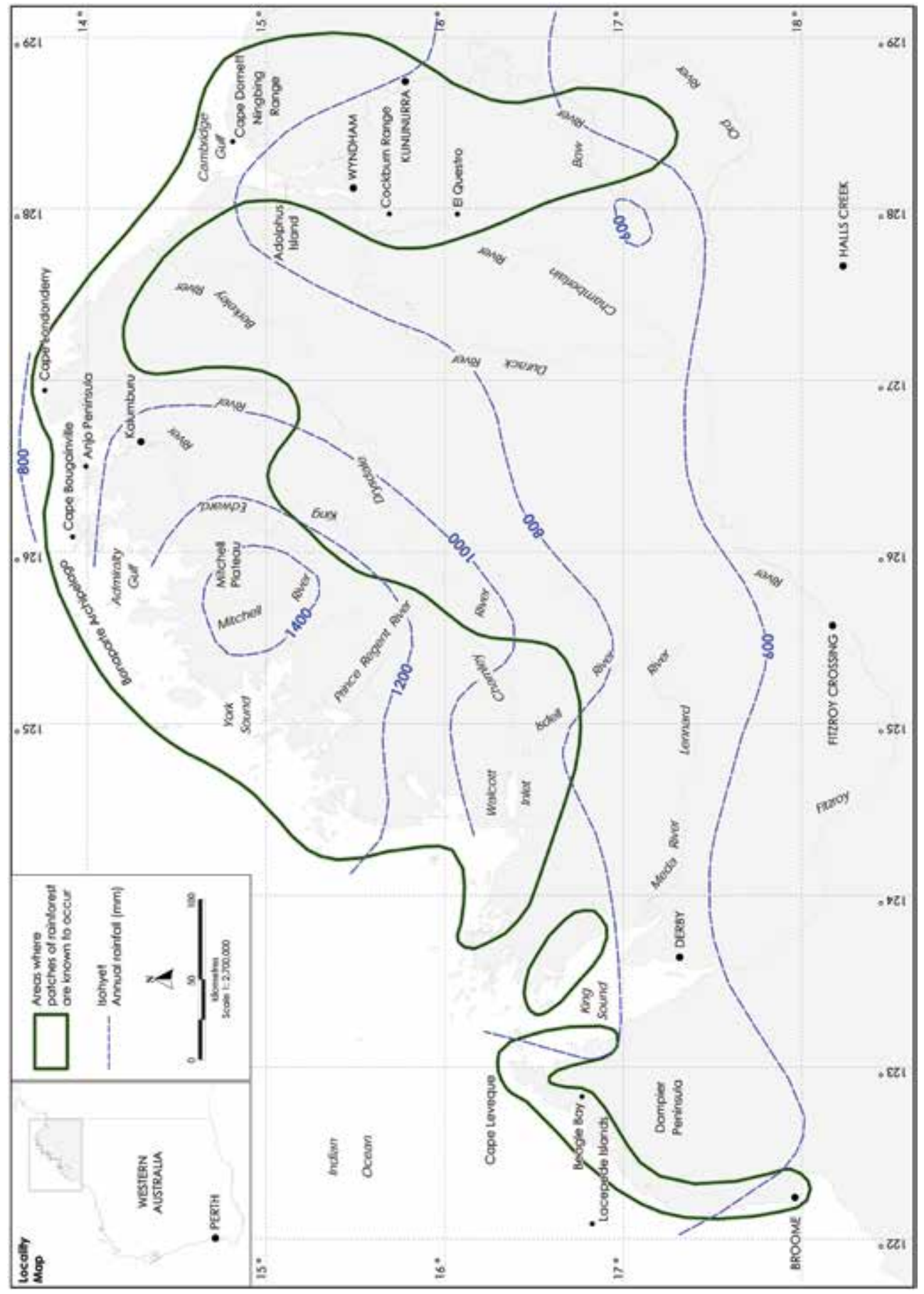

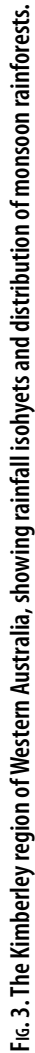




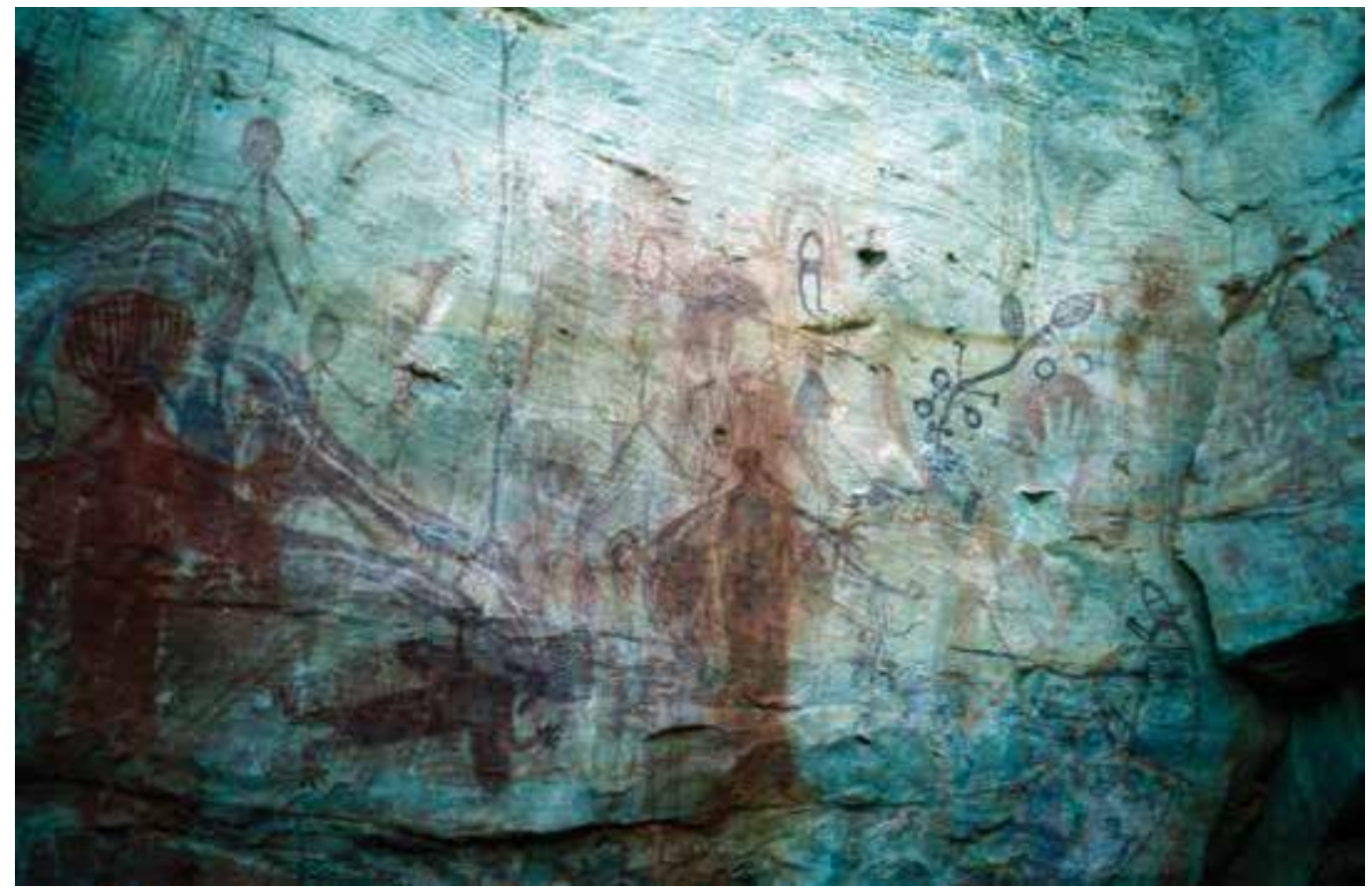

FIG. 4. Depictions of plants are found on Aboriginal rock art galleries across the Kimberley.

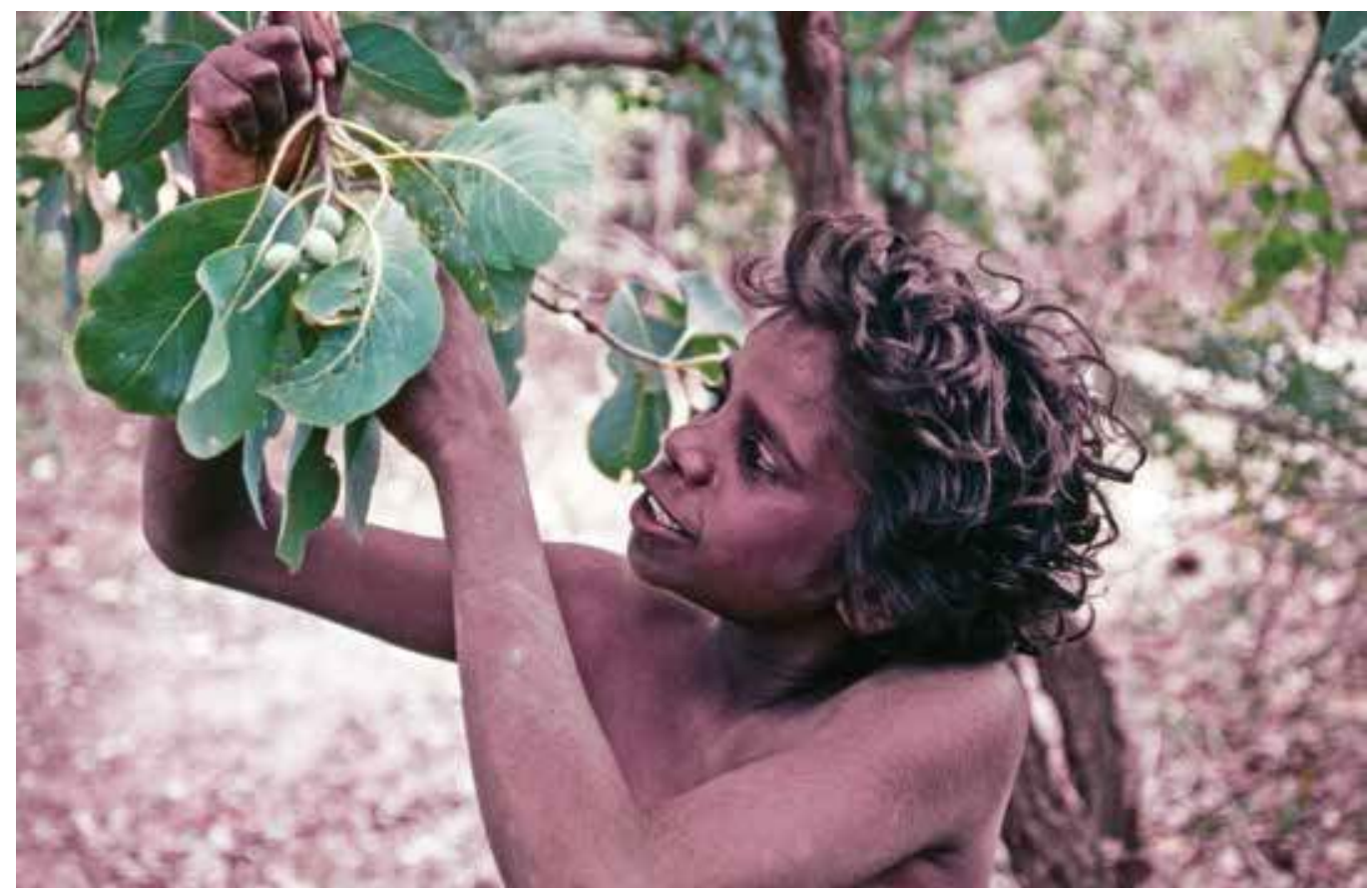

FIG. 5. Graham Donation of Broome harvesting ripe fruits of Gubinge (Terminalia ferdinandiana).

This document is intended for digital-device reading only.

Inquiries regarding distributable and open access versions may be directed to jbrit@brit.org. 
Karadada et al. (2011) describe 96 and 106 plant foods respectively from Kalumburu in the north Kimberley, and Vigilante et al. (2014) recorded 127 plant food species from Kimberley islands. Each study notes that most of these plant foods were used for casual or occasional meals (Fig. 5).

To Aboriginal people "country" is a complex living cultural landscape. The country is therefore embellished with enormous meaning and relevance to their traditional lifestyle. Aboriginal people's connection to country is influenced by their belief systems, long occupation, and an extensive knowledge of natural cycles, all of which relate to both extended and more local stretches of country. As monsoon rainforests were prime food-gathering areas Aboriginals would not burn them and would try to protect them from fires by burning the grassland around a rainforest patch early in the dry season. If these protective fires were lit every year the rainforest would never burn (Mangglamarra et al. 1991). Today, indigenous groups are increasingly combining traditional ecological knowledge and Western scientific approaches to inform management of their lands (Vigilante et al. 2017). Some patches were also culturally sensitive law-grounds (Belfield et al. 2012: Black et al. 2010). At Broome, the Lurujarri Heritage Trail connects to specific sites (Law Grounds) and follows the land of the traditional Song Cycle. Traditional Law was encoded in the Song Cycle and has been passed down unbroken since the Dreamtime (Bugarregarre). The Lurujarri trail traverses $80 \mathrm{~km}$ of saltwater coastal terrain and its path embraces patches of monsoon vine thicket.

The fact that the Bardi and Goolarabooloo languages of the Dampier Peninsula include the word budan, meaning monsoon vine thicket, confirms the importance of this plant community to Indigenous people. Bardi people also call it mayi boordan, meaning "bush fruit country." Yawuru people call it mayingan manja balu, meaning "plenty of fruit trees" (Beames 2013). In the north Kimberley, it is called wulo in the Wunambal and Gaambera languages (Vigilante et al. 2017).

Local Aboriginals understood that the monsoon vine thicket patches function as a system or network and that the occurrence of "bush fruit" differed from patch to patch. Aboriginal concepts of seasonality are more complex than that of a simple wet-dry season pattern. The Bardi and Yawuru people recognize six seasons, distinguished mainly by wind, rainfall direction and intensity, ripening of fruits, and appearance or disappearance and "fatness" of fish or animals.

\section{EUROPEAN DOCUMENTATION OF MONSOON RAINFOREST IN THE KIMBERLEY}

Botanical observation in the Kimberley district began as early as 1688 with the visit of William Dampier, who recorded a general description of some vegetation (Grant-Richards 1906; George 1999). The first contact with the rainforest would appear to have been made by botanical collector Alan Cunningham in 1819-22 when he accompanied the voyages of Lieutenant P.P. King charting the Kimberley coast (King 1827). Many of Cunningham's specimens are derived from the monsoon forest, but he left no published record of vegetation types. In his unpublished journal Cunningham does, however, refer to the monsoon forest. On 16 September 1820, he recorded the following from the Hunter River:

"... steep rocky ridges of hills, furrowed with channels formed by the torrents that doubtless fall from their elevations during the season rains, through interesting bushes which clothe the declivities with a luxuriant verdure. These thickets afforded me some variety of plants...."

And again, on 17 September:

"Thickets clothing the broad bases of the lofty towering boundary cliffs at length become interesting. In them I observed some remarkably fine large trees of Myristica laden with its fruit ..., and a tree of very regular ornamental growth, having dark green opposite leaves, nerves as in Calophyllum.... The Cryptocarya was likewise frequent."

The first recognizable encounter with the monsoon rainforest that has been found in the literature was recorded by Julius Brockman in November 1879. Brockman (1880) made particular note of the dense monsoon vine thickets found behind the coastal sand dunes on the north end of the Dampier Peninsula.

"We turned into the beach again at sunset ... and had hard work to force our way through the jungle that skirts the sea hills, having to get out our knives to cut the tangled masses of the creeper, often as strong as rope."

Sir George Grey was the first to record the Pied Imperial Pigeon (Ducula bicolor) in Western Australia, a bird reliant on fruiting monsoon rainforest patches. Grey collected two specimens on 17 December 1837 at Hanover Bay, near the mouth of the Prince Regent River (Johnstone 1981). In 1910 several rainforest bird 
species including the Orange-footed Scrubfowl (Megapodius reinwardt), and Rose-crowned Fruit-dove (Ptilinopus regina), were recorded by field-collector Gerald Hill in "dense tropical scrubs," composed of "tropical trees, shrubs and creepers" at Parry Harbour in the north Kimberley (Hill 1911).

These early encounters tended to be superficial and inconclusive, and it was not until 1923 that the first general account of the vegetation of the Kimberley was given by C.A. Gardner (1923), who explored the northwest Kimberley botanically in 1921 when travelling with the expedition of W.R. Easton (1923). Even then, however, Gardner failed to observe and record monsoon vine thickets and forests, speaking in his account of the "total absence of rainforests." Unaccountably, he apparently never saw the numerous discrete patches in the Mitchell Plateau area, although his party traversed the plateau end to end. There is no mention of any elsewhere, such as in the Prince Regent River, nor does the list of species found on the expedition suggest that he had collected in them.

In a later work, Gardner (1944) emphasized the prominence in the flora of the Kimberley of an "IndoMelanesian element," equated with the "Palaeotropic element" of the Australian flora defined by Hooker (1860). On scrutiny, however, it is found that Gardner was referring generally to tropical species found in the littoral zone, riverine forest, woodlands and savannas, rather than to the monsoon forest to which the term might more appropriately relate.

Traversing of the north Kimberley by members of the Land Research Division of CSIRO in 1954 was limited by inaccessibility of the country and there was similarly no mention in their report of rainforests (Speck 1960). In fact, Speck stated that: "There are no rainforests, usually considered characteristic of the tropics, and even the monsoon forests described for the Katherine-Darwin region by Christian and Stewart (1953) are absent." However, the existence of monsoon vine thickets at the Mitchell Plateau was eventually brought to light in the course of a geological survey in 1965 carried out jointly by the Bureau of Minerals Resources and the Geological Survey of Western Australia and reported in the explanatory notes to the Montague Sound 1:250 000 geological sheet (Allen 1966, 1971).

In 1965, the Amax Bauxite Corporation began to investigate bauxite deposits on the Mitchell Plateau. A mining camp was established and linked to the outside world by air and by vehicle track. As a result, scientists of many disciplines visited the Plateau and became aware of the monsoon rainforest. The first actual study was made by J.S. Beard in 1974 who published a preliminary description and classification, along with a map showing the more important patches (Beard 1976). Beard also drew attention to the relatively more extensive occurrence of monsoon vine thickets on the Bougainville Peninsula, which no botanist had yet visited. At about the same time, P.G. Wilson and N.G. Marchant of the Western Australian Herbarium examined a number of the islands off the northwest Kimberley coast during biological survey expeditions coordinated by the Department of Fisheries and Wildlife and reported and collected in patches of monsoon vine thicket (Burbidge \& McKenzie 1978).

Also, in 1974, a biological survey of the Prince Regent River Reserve in the north Kimberley was coordinated by the Department of Fisheries and Wildlife (Miles \& Burbidge 1975). This gave no general account of the vegetation; the work being based on the detailed recording of twelve sites. However, the expedition was able to report finding "semi-deciduous monsoon vine thickets" at three of these, and closed forest of Calophyllum sil, Melaleuca leucadendra, Carallia brachiata, and Myristica insipida along river and creek beds. The following year, a similar survey of the Drysdale River National Park (Kabay \& Burbidge 1977) disclosed the presence of three communities of monsoon semi-deciduous vine thicket and one of riverine closed forest as described above.

Related botanical surveys were made by Hnatiuk and Kenneally (1981) of the Western Australian Herbarium in 1976, 1978 and 1979, and their report on the vegetation and flora of the Mitchell Plateau was included in a Western Australian Museum biological survey publication (1981). A list and description of twenty-six communities (one being the monsoon vine thickets) was given, along with an annotated list of the flora of which approximately 80 taxa belonged to the monsoon rainforest. Beard, Clayton-Greene and Kenneally (1984) were at the Plateau conducting a survey for the mining company in 1978 and 1979 when the 
Bougainville Peninsula was also visited. In 1982, Kenneally returned to the Plateau in January, April, October and December. In April and October, he again visited Bougainville Peninsula, during which time extensive helicopter traverses were made and botanical specimens collected. These visits resulted in a private report to the company, a paper on the monsoon vine thickets of the Bougainville Peninsula and another on the fire ecology of the monsoon vine thickets of the north Kimberley (Clayton-Green \& Beard 1985).

The surveys of the Prince Regent River Reserve and Drysdale River National Park in 1974-75 demonstrated that the monsoon vine thickets are not an isolated phenomenon of the Mitchell Plateau area. Aerial inspection on flights to and from the Plateau disclosed that monsoon vine thicket patches are common throughout the northwest coastal region, and subsequent visits by sea to this area confirmed their occurrence at the Walcott Inlet, Sale and Glenelg Rivers, Camden Sound, and St George Basin on the Prince Regent River.

The known range of the monsoon vine thickets was extended to the southwest Kimberley, an area of substantially lower rainfall, when a biological survey of the Dampier Peninsula documented their occurrence behind coastal dunes as foreshadowed by Brockman in 1880 (McKenzie \& Kenneally 1983). The thickets occur in frequent patches, more commonly at the north end of the Peninsula, on the lee side of the coastal dune system. This habitat was not previously known to be occupied by monsoon vine thickets in Western Australia, though it is a common element in the Northern Territory and Queensland (Beard \& Kenneally 1993).

Between 1987 and 1989 the first broad-scale quantitative ecological survey was undertaken of the Kimberley rainforests (McKenzie et al. 1991). Data were collected on compositional patterns of biota, disturbance and physical characteristics of the environment at 95 rainforest patches. The results of this survey provided information on soil and landform, invertebrates and vertebrate fauna, floristics, vegetation structure and spatial distribution of rainforest patches. More recently studies of rainforest patches occurring on a number of Kimberley islands have been undertaken by the State Department of Biodiversity, Conservation and Attractions and by INPEX, (an oil and gas company) on the Bonaparte Archipelago and Browse Basin (Comrie-Greig \& Abdo 2014; Gibson et al. 2014).

\section{CLIMATE SUPPORTING TROPICAL MONSOON RAINFOREST DISTRIBUTION IN THE KIMBERLEY}

The climate of Australia's vast Kimberley region is dominated by the Australian summer monsoon, which forms part of a wider climate system, including the Indo-Pacific Warm Pool (IPWP) which plays a major role as a global heat source driving planetary scale circulation (Keenan et al. 1989, 2000). The tropical monsoon climate is characterized by two distinct seasons, a "wet" and a "dry," with several transition periods within each season. Precipitation in the Kimberley is dominated by the Australian summer monsoon and tropical cyclones, both of which typically occur during the austral summer between November and March associated with the seasonal southward migration of the Inter-Tropical Convergence Zone (ITCZ) (Suppiah 1992). Generally, the wet season lasts from November to March and the dry season from April to October. The dry season is virtually rainless, with easterly winds and cooler nights. The wet season however, can bring torrential rain and widespread flooding associated with cyclones and tropical thunderstorms. The broad average annual rainfall for the region is 950 millimeters $(\mathrm{mm})$, with Mitchell Plateau receiving an annual average of $1,500 \mathrm{~mm}$. Almost all of this rain occurs during the wet season. Temperatures are high throughout the year, with annual averages between $25^{\circ} \mathrm{C}$ and $35^{\circ} \mathrm{C}$ (Beard 1979; Bureau of Meteorology 2016).

Monsoon rainforest is represented in Western Australia only in the tropical portion of the State, (north of Broome at $18^{\circ}$ latitude), an area known administratively as the Kimberley district and biogeographically as the Northern Botanical Province (Beard 1979). Within this region, the monsoon forest is present only in small scattered patches within $150 \mathrm{~km}$ or less of the northwest coast, extending from Broome in the south, where the minimum rainfall is $600 \mathrm{~mm}$ per annum to Cape Londonderry in the north, where the maximum is $1,500 \mathrm{~mm}$. (Fig. 3). Outlying peninsulas and islands are known to be relatively dry, the highest rainfall occurring on elevated ground inland of the main coastline.

The patches of monsoon vine thickets on the Dampier Peninsula, in contrast to other Kimberley and northern Australian rainforests, are at the southern limit of their range and occur in the swales of coastal dunes and are dependent on groundwater from the Broome aquifer (Department of Water and Environmental 
Regulation 2017). Monsoon forests are not known to occur where the annual rainfall drops below $600 \mathrm{~mm}$. On average, Broome receives $540 \mathrm{~mm}$, Beagle Bay $725 \mathrm{~mm}$ and Cape Leveque $718 \mathrm{~mm}$ for these locations, trending northward on the Dampier Peninsula. Survival of these coastal patches may be aided by fog providing a supplementary water source. On average Broome (and the Dampier Peninsula) has 22 foggy days each year from June to September-the "Dry" season (Collins 2012). Fog can persist all day. In July 1986, the author observed at Middle Lagoon, $25 \mathrm{~km}$ northwest of Beagle Bay, that the fog that was so dense, visibility was reduced and the vegetation was dripping wet. The fog extended $30 \mathrm{~km}$ offshore to the Lacepede Islands. The importance of fog water absorption by plants and animals in an arid country has been documented for the Namib Desert (Van Damme 1991: Shanyengana et al. 2002).

\section{KIMBERLEY MONSOON RAINFOREST ENVIRONMENTS}

The landscape in the northwest Kimberley is mostly underlain by sandstones but also partly by basalt (Fig. 6). The sandstone country is generally very rugged, consisting of a high degree of stacks of bare rock with vegetation growing out of crevices and soil cover only in some low-lying places. The country becomes more rugged and barren closer to the coast, but further inland it becomes more even, undulating and soil covered. Sandstone country is typically dissected by narrow gorges formed along joints, so that drainage has a rectilinear pattern. Basalt country on the other hand typically consists of rounded hills of moderate to low relief with a dendritic drainage pattern and richer deeper soils. Outcrops of boulders and sheet rock are a common feature. Near the coast, relief is greater and dissection of individual lava flows from the basaltic ground mass gives rise to a topography of pronounced structural benches and mesas.

Remnants of a duricrusted plateau surface occur on the basalt, the largest of these being the Mitchell Plateau with a surface area of 220 square $\mathrm{km}$, and plateau remnants on the Bougainville Peninsula covering 85 square $\mathrm{km}$ (Allen 1974). The duricrust is bauxite, some two meters thick, and underlain by a kaolinized weathered zone averaging 17 meters in thickness (Amax Exploration Company nd). Remnants of residual plateau take the form of conspicuous mesas bordered by deeply indented scarps.

On the Bougainville Peninsula, monsoon rainforest is widespread on the undulating basalt country and may form semi-deciduous monsoon rainforest on scree slopes of the plateau. Eucalyptus/Corymbia savanna woodland is also found in both cases, either in pure patches or mixed with monsoon vine thicket elements.

Botanical exploration of the northwest coastal country between King Sound and the Admiralty Gulf has disclosed that the typical pattern of the Mitchell Plateau area is repeated, with patches of monsoon vine thicket and forest on benched basalt topography, and also on sandstone scree slopes overlying basalt at the foot of sandstone scarps. This latter habitat recalls the breakaway slope habitat of the Mitchell Plateau and is developed where overlying Warton and King Leopold Sandstone has exposed underlying basalt, a common situation between Doubtful Bay and Prince Frederick Harbor. The occurrence of monsoon vine thicket is by no means confined to the basalt country but occurs less frequently on the sandstone (Beard 1976).

An entirely different habitat not so far encountered in the northwest Kimberley is found on the Dampier Peninsula further south, where the annual rainfall is from 600 to $800 \mathrm{~mm}$. The substrate are deep Holocene dune sands, white except for a superficial dark grey organic layer covered by leaf litter up to six centimeters deep (Beard \& Kenneally 1993).

\section{KIMBERLEY MONSOON RAINFOREST BIO-COMPLEXITY}

Currently four major habitat categories of monsoon rainforest are recognized in the Kimberley: those on hillsides and scree slopes; along swamps and rivers; behind Holocene coastal sand dunes; and in gorges and gullies. In addition, there are depauperate patches containing rainforest elements on the Devonian limestones of the Ningbing Ranges north of Kununurra (N.L. McKenzie pers. comm.) (Fig. 7).

Mangrove communities of southeast Asia are also treated as a special sort of rainforest by Whitmore (1984) as they include not only "true mangrove species" but incorporate plant species normally found in other habitats (Giesen et al. 2007). Kimberley mangrove communities are completely distinct floristically from rainforest but as they are often contiguous or in close proximity to rainforest patches and have served as refugia during sea level change, they are considered as an extension of the closed-canopy community. Many of the bird 


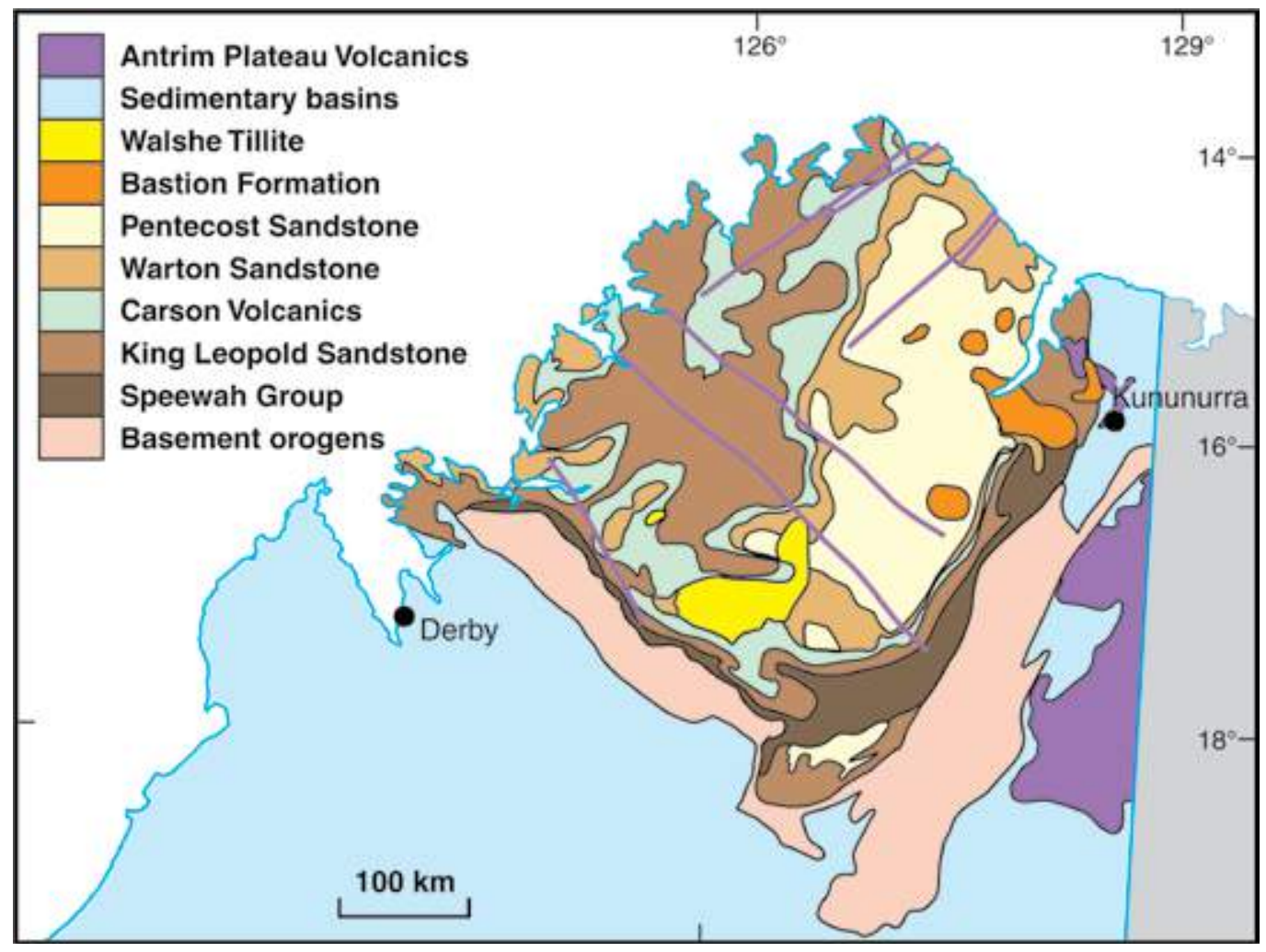

FIG. 6. Geology of the Kimberley (reproduced with permission from Donaldson 2012).

and mammal species of the rainforest also depend on and utilize the vast stands of mangroves that fringe the tidal creeks and coastline (Figs. 8-20).

Australian rainforest communities are believed to contain taxa of both Gondwanic and Laurasian origins (McKenzie et al. 1991). About 49 million years ago, the Australian plate separated from the Antarctic continent and began drifting northward (Truswell 1993), carrying with it part of the Gondwanaland biota. This is thought to have included rainforest vegetation - the autochthonous elements. Following collision with Asia during the Miocene numerous rain forest lineages migrated into northern Australia (Sniderman and Jordan 2011). Fossil evidence suggests that most of the Tertiary Australian continent was covered by rainforest. Rain forests were still widespread in Australia in the late Eocene (35 Ma) including in inland areas that are now arid (Macphail 2007). The loss of rainforests in central Australia around 10 Ma was a consequence of increasing aridity (Byrne 2008). Indomalaysian rainforest species (the intrusive elements) began colonizing the northern part of the Australian Continental plate from the early Tertiary (Kershaw 1988) and "a strong contact between the floras of the Australian and Indomalayan regions...established from Miocene times (Barlow and Hyland 1988). Over the last 20 million years (especially the Miocene and Pliocene), as climates became more variable and, perhaps seasonally arid (Nix 1982), these rainforests were gradually replaced by more open scleromorphic and xeromorphic vegetations (Truswell and Harris 1982). Drying climates resulted in rainforest becoming restricted to areas retaining suitable climate along the Great Dividing Range and east coast (Floyd 1990; Crisp et al. 2004).

Kimberley rainforest species may have survived the Pleistocene fluctuations in mangrove or littoral vegetation near the edge of the exposed continental shelf, in riverine vegetation, or in refuges associated with the 


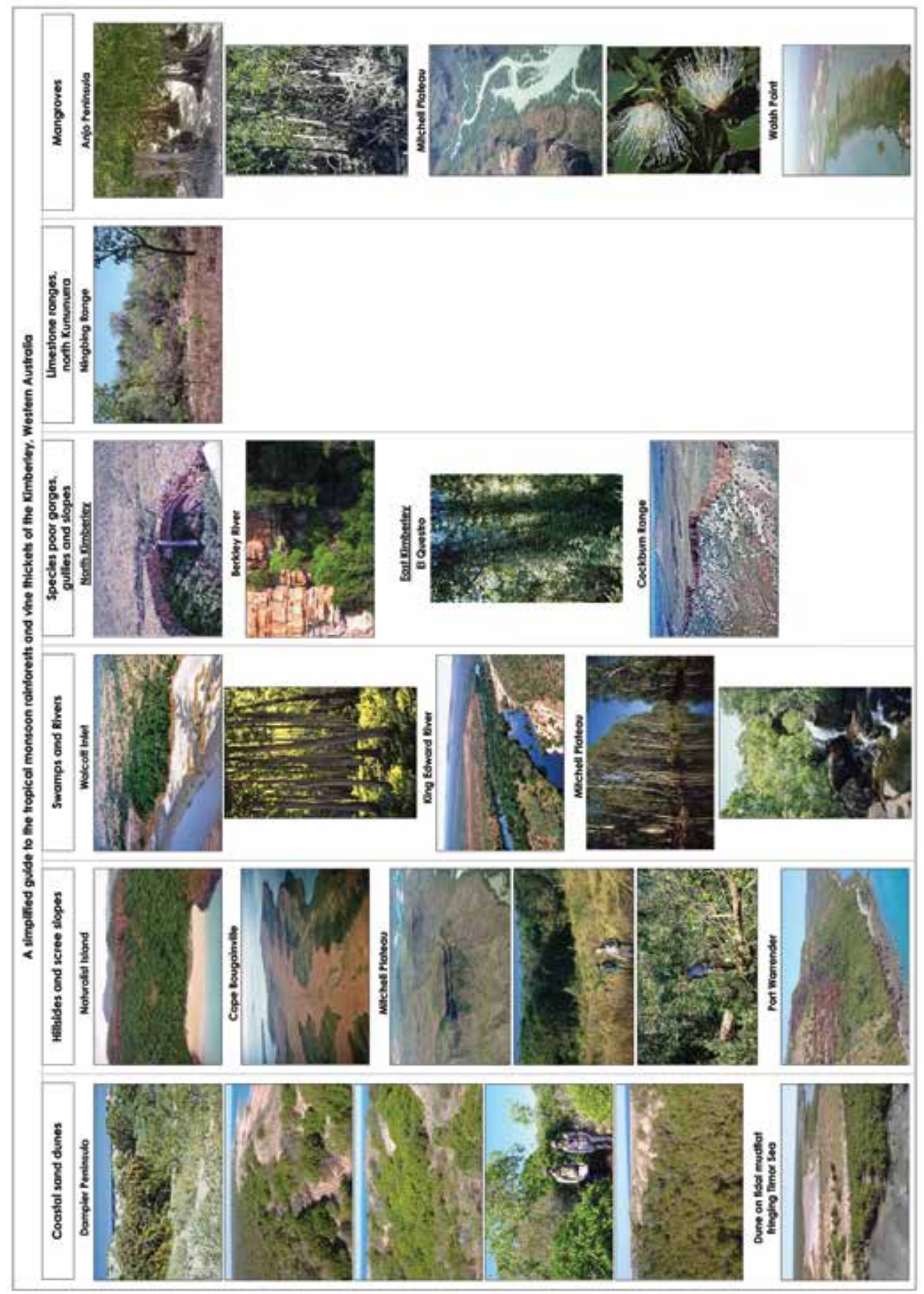

월 


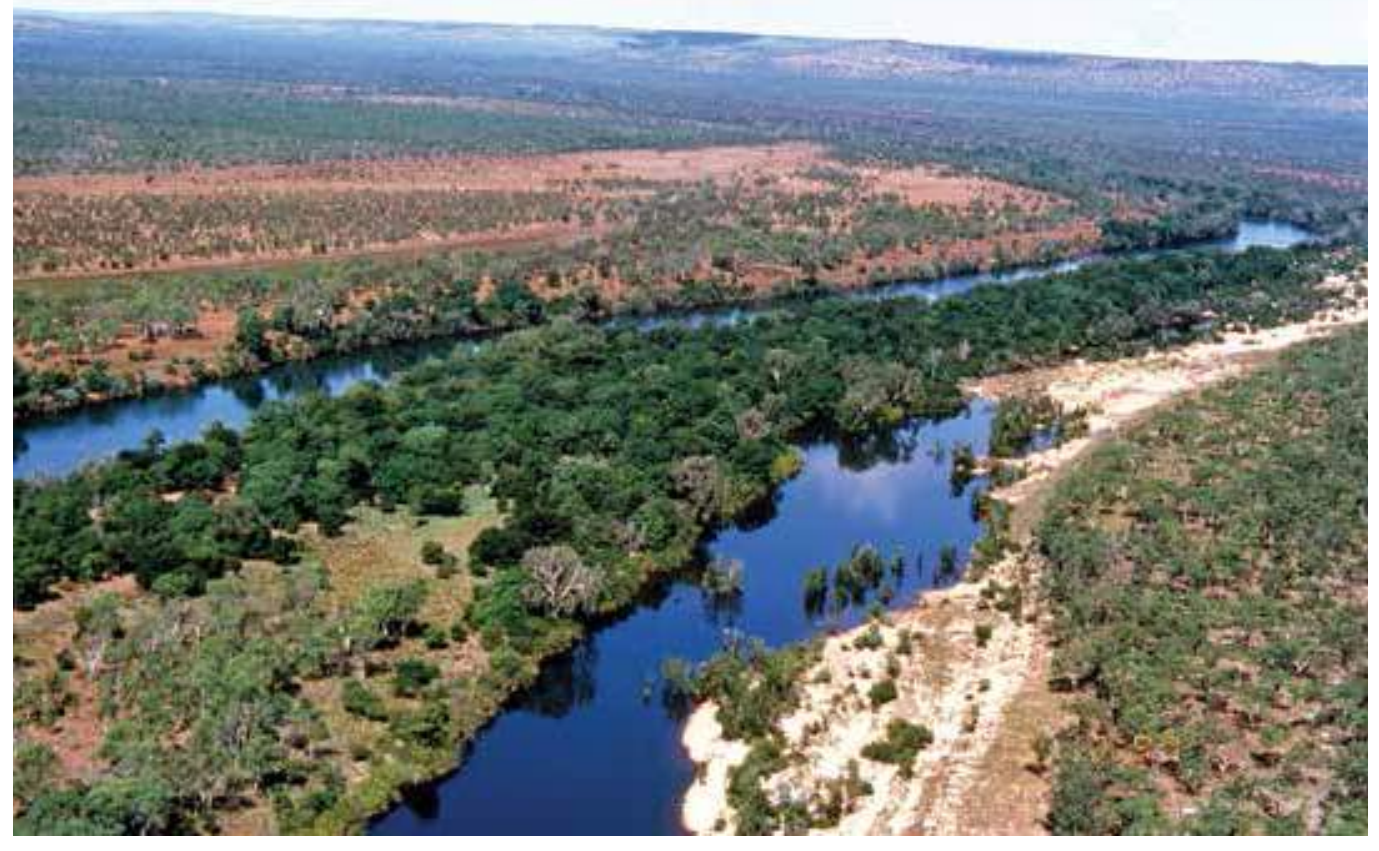

FIG. 8. Rainforest on a levee bank in the King Edward River, south of Kalumburu. Image—N. McKenzie.

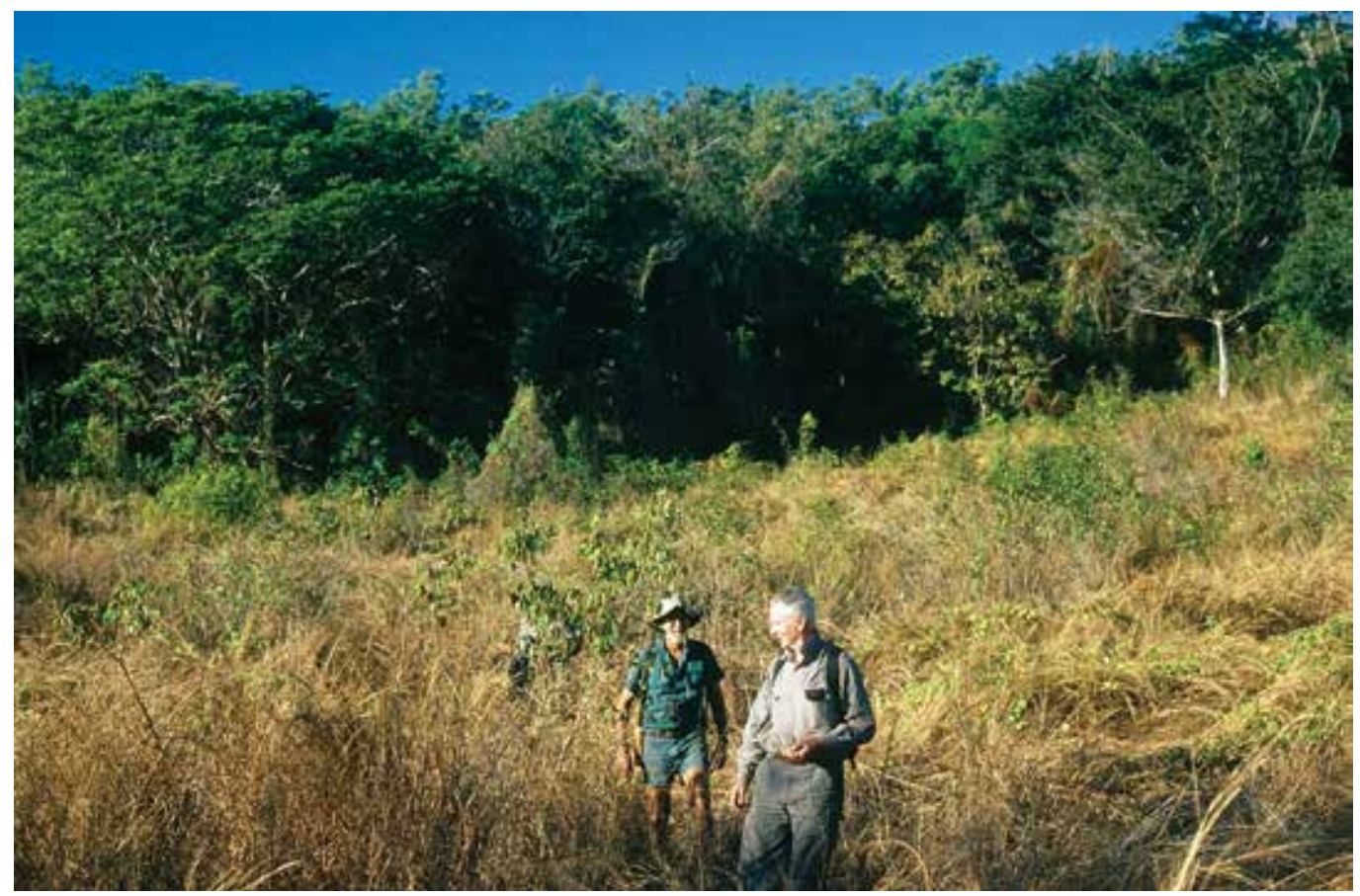

FIG. 9. Patch monsoon rainforest "Crusher Thicket" at Mitchell Plateau.

This document is intended for digital-device reading only.

Inquiries regarding distributable and open access versions may be directed to jbrit@brit.org. 


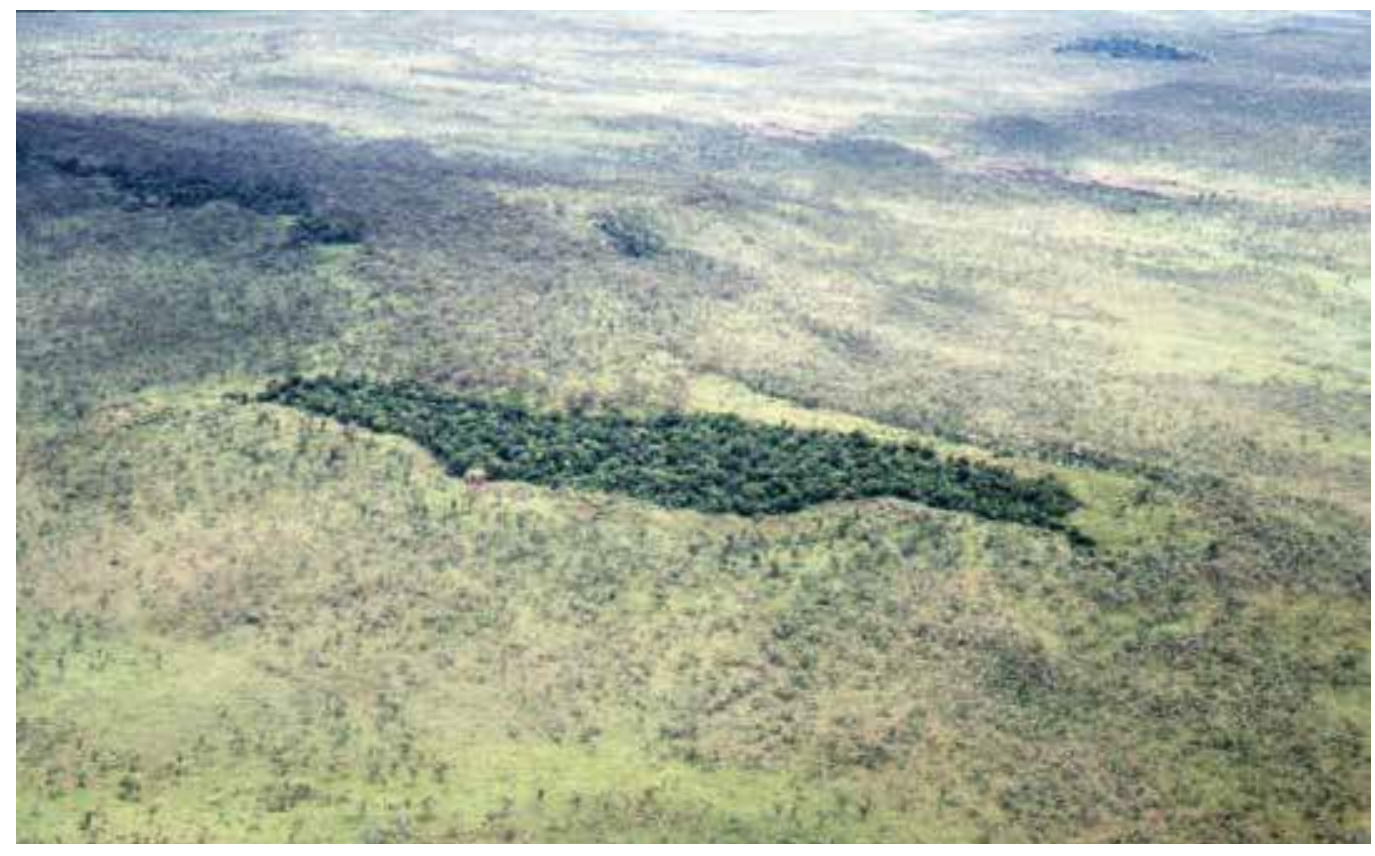

FIG. 10. Isolated patch monsoon rainforest on Mitchell Plateau surrounded by savanna woodland.

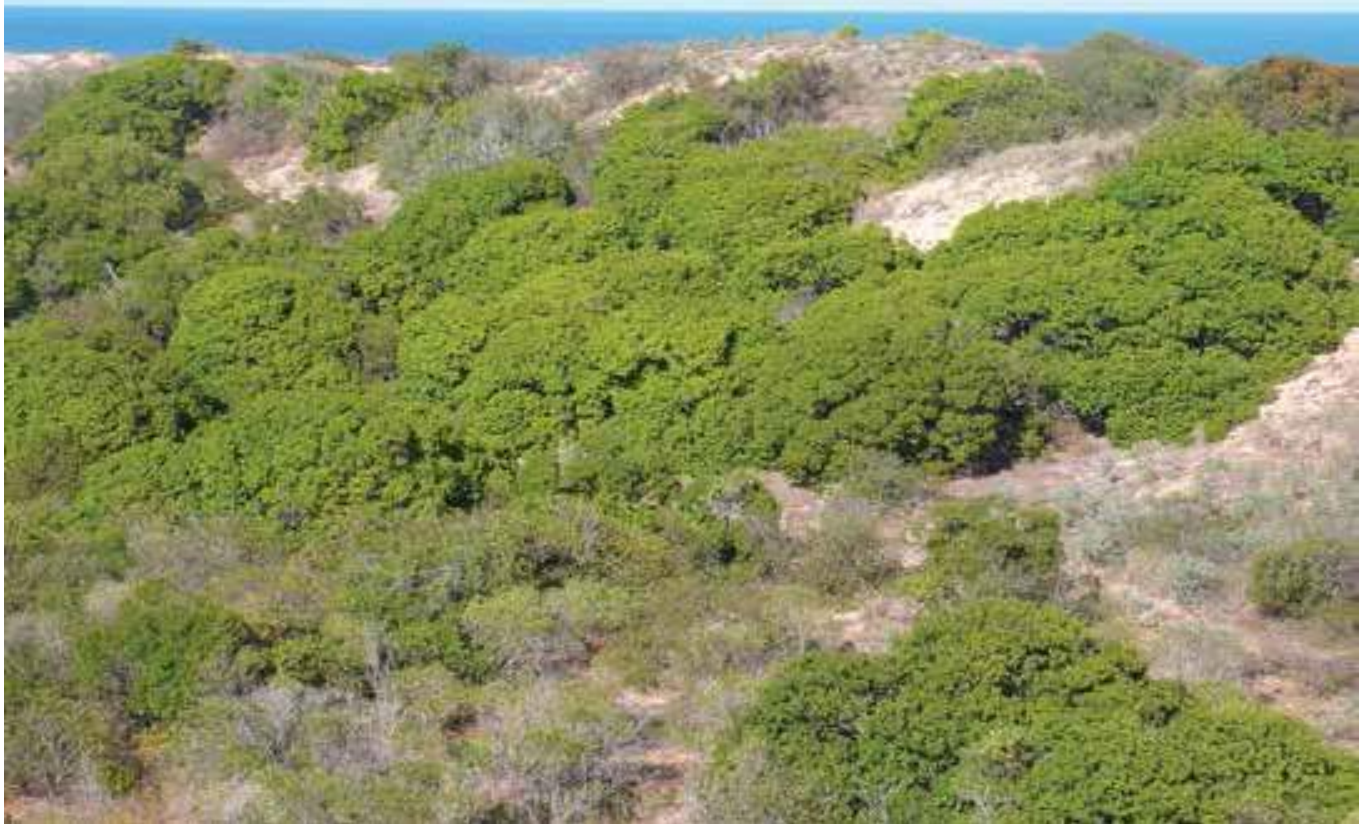

Fig. 11. Southern-most patch monsoon rainforest (vine thicket) behind coastal Holocene dunes at Coulomb Point, north of Broome, Kimberley, Western Australia. 


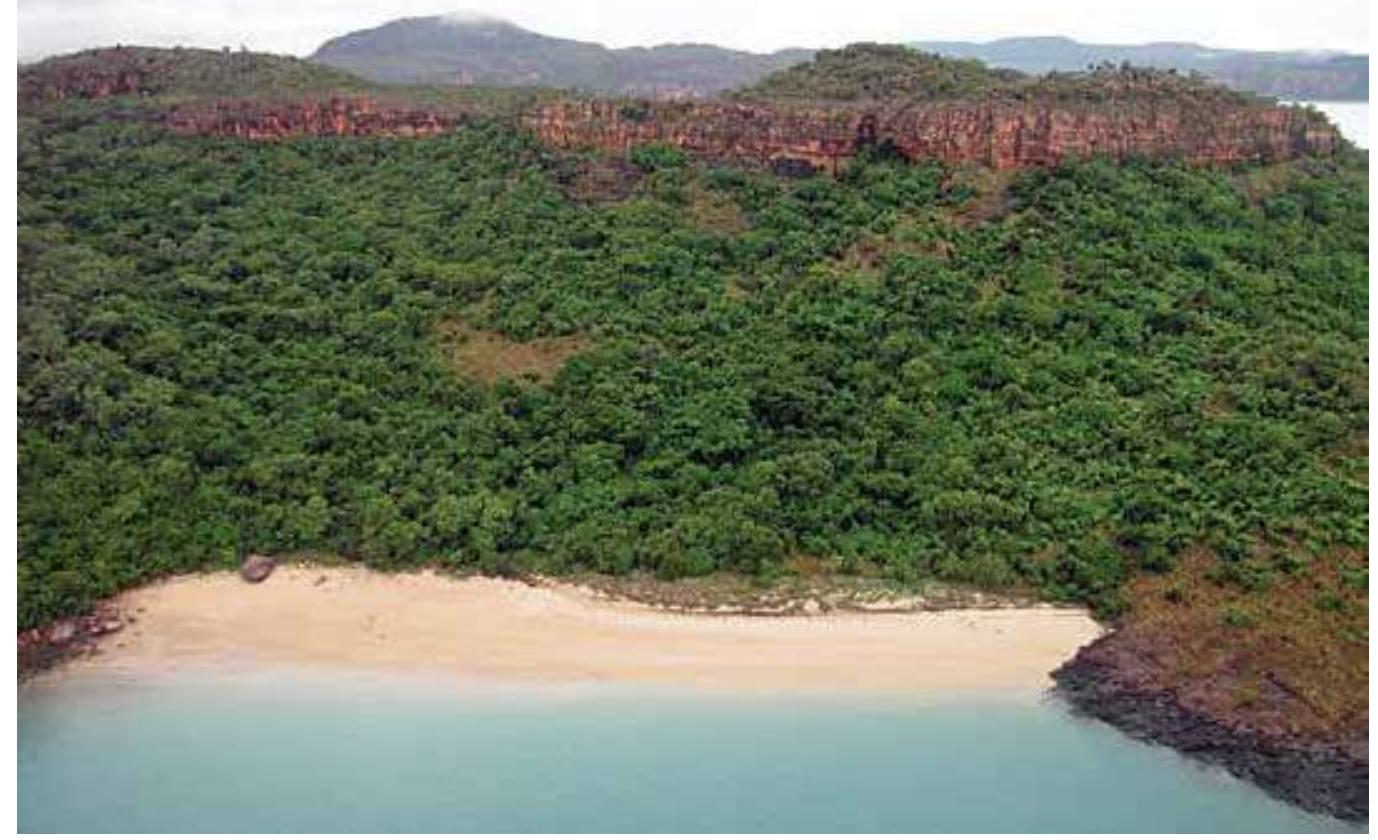

FIG. 12. Monsoon rainforest on scree slope at Naturalist Island at the mouth Hunter River, Kimberley.

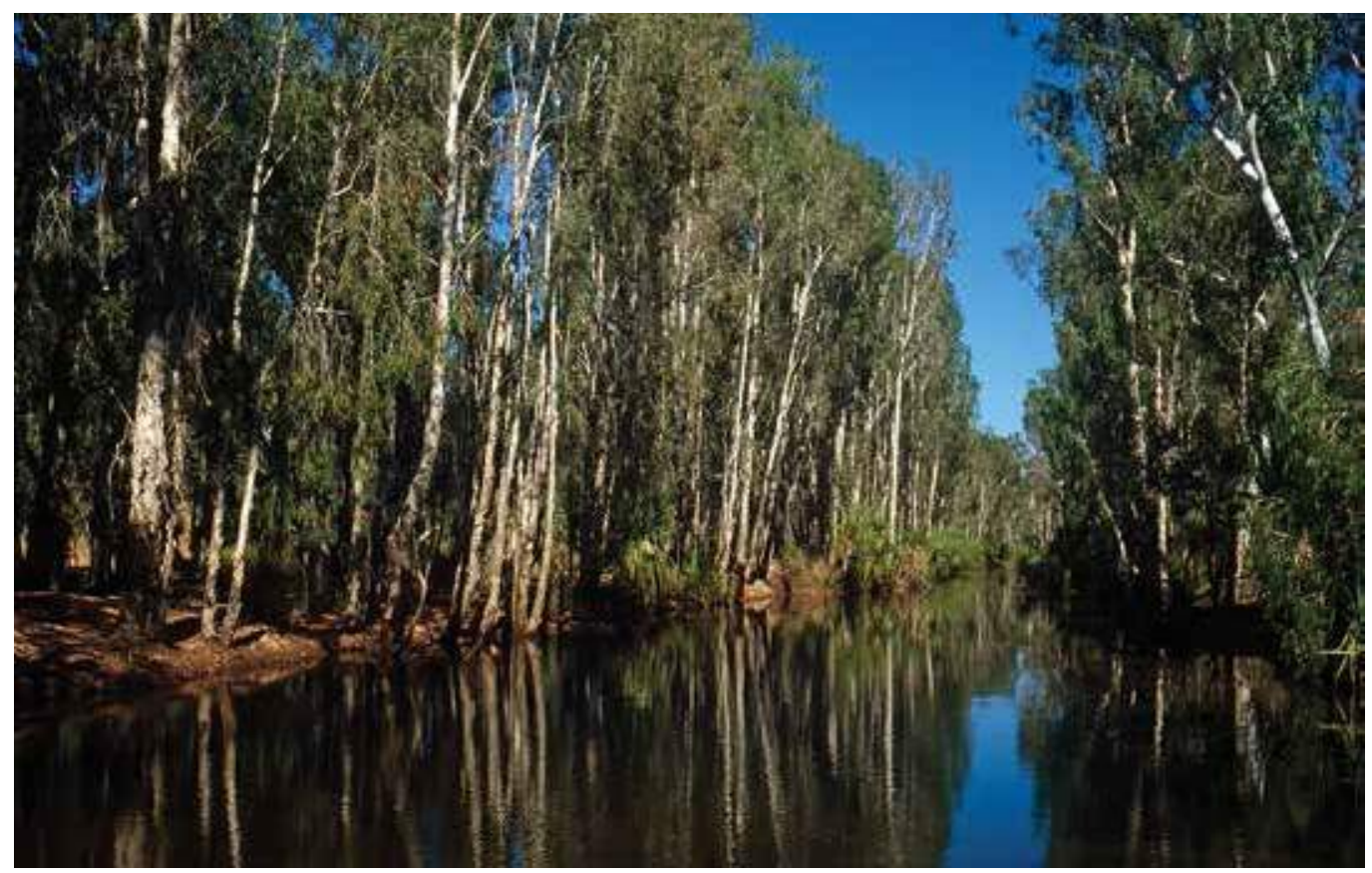

FIG. 13. Riparian forest dominated by paperbarks (Melaleuca leucandendra) and Screwpines (Pandanus aquaticus and P. spiralis). 


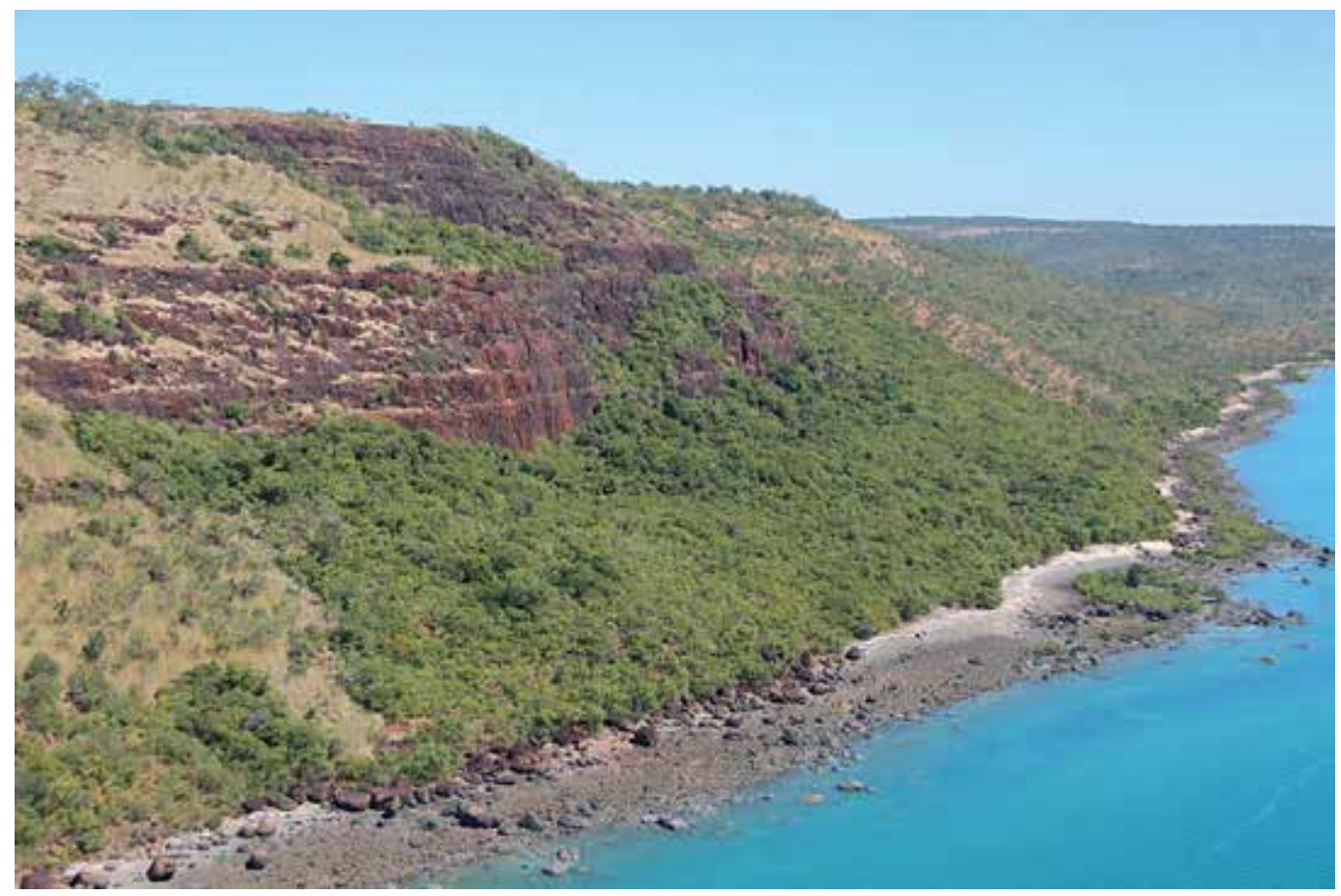

\section{FIG. 14. Monsoon rainforest on Carson Volcanic (basalt) benches at Port Warrender, Mitchell Plateau. Image - T. Willing.}

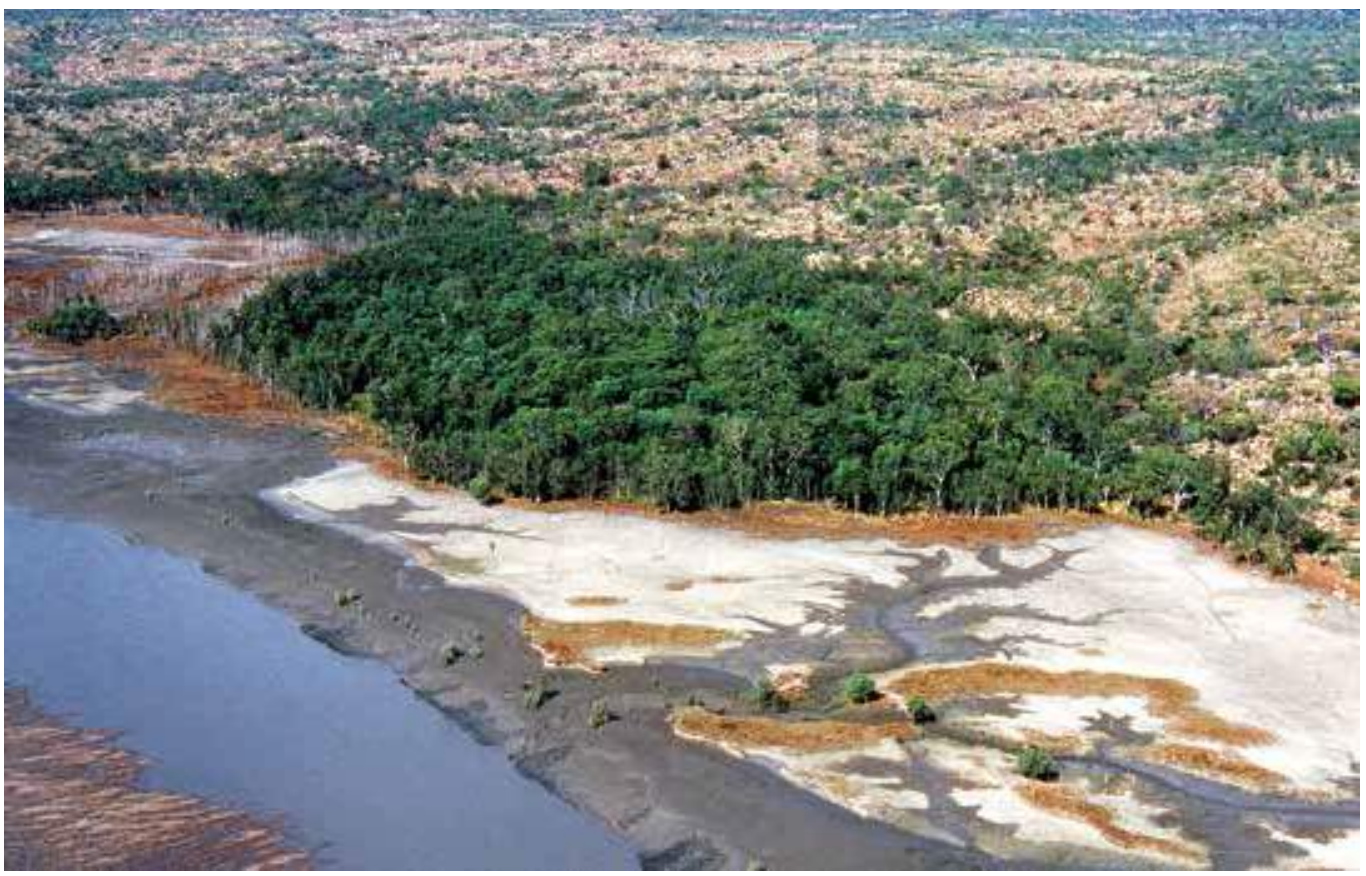

FIG. 15. Tall closed-canopy swamp rainforest on edge tidal mudflat at Walcott Inlet. Image-N. McKenzie. 


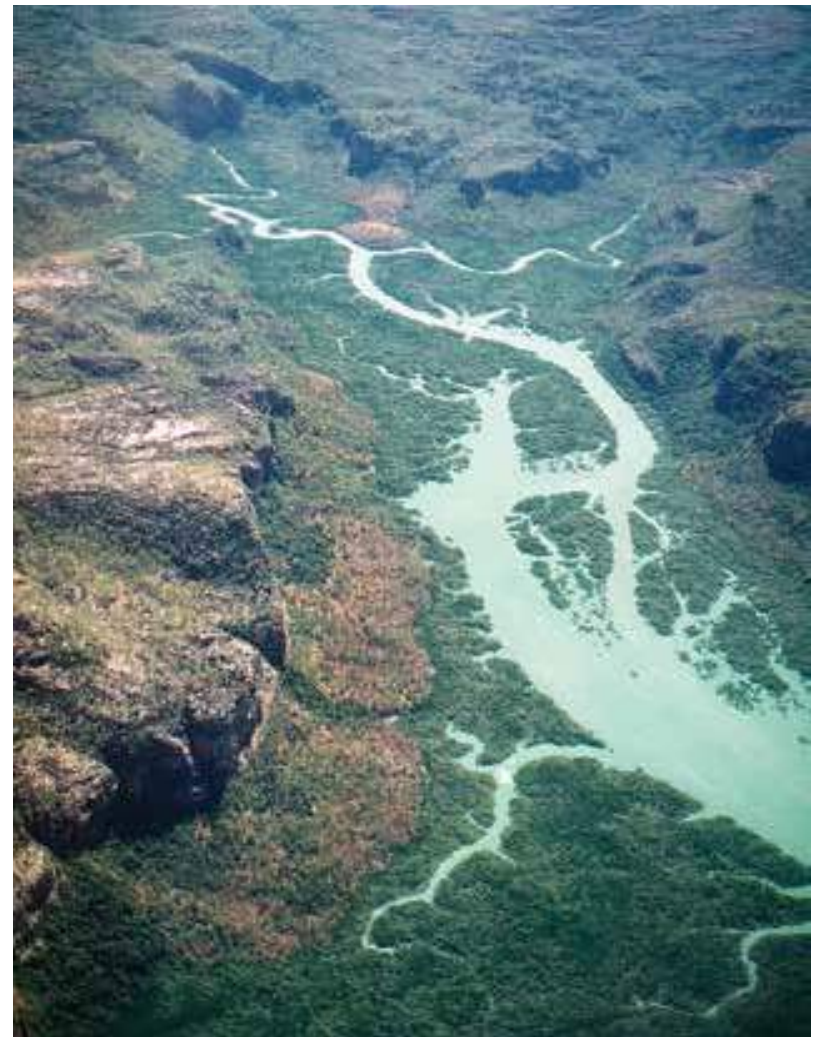

FIG. 16. Tidal creek at Mitchell Plateau showing the close proximity of monsoon rainforest to mangroves.

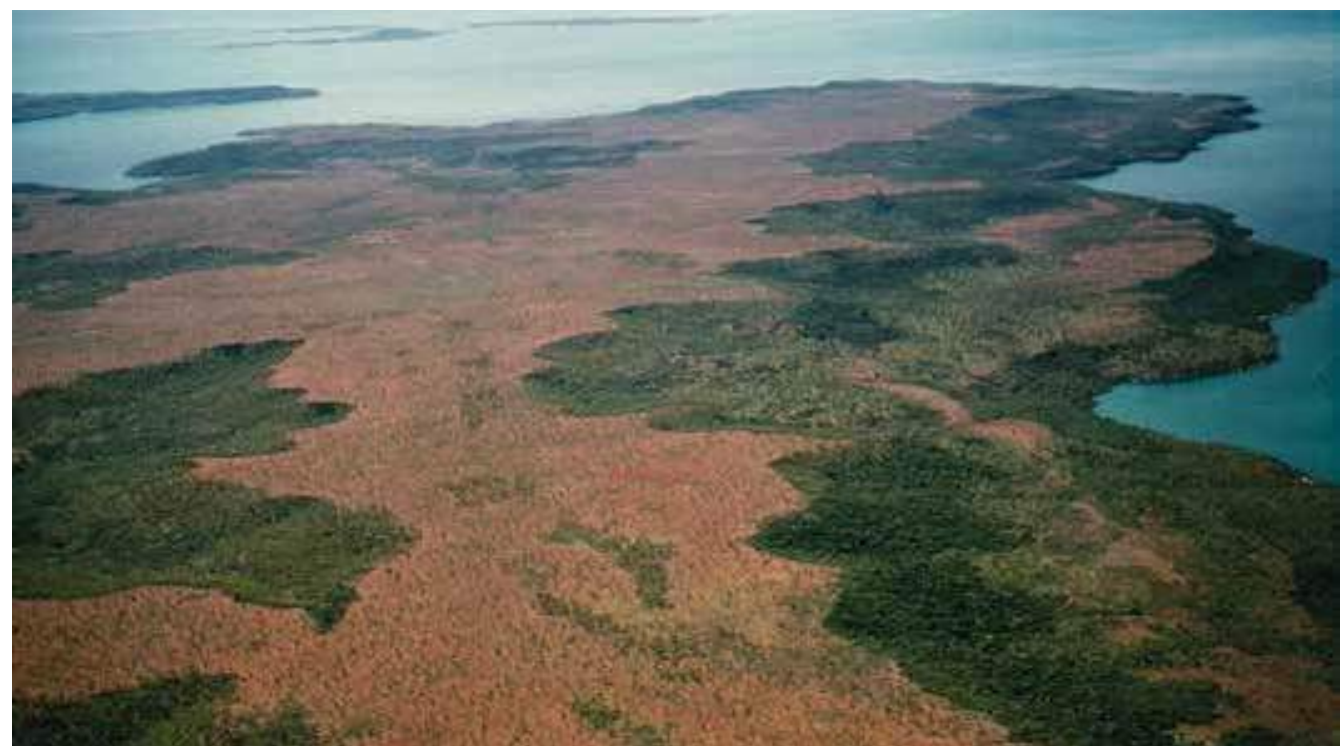

FIG. 17. Monsoon rainforest fringing dissected laterite plateau at Cape Bougainville.

This document is intended for digital-device reading only.

Inquiries regarding distributable and open access versions may be directed to jbrit@brit.org. 


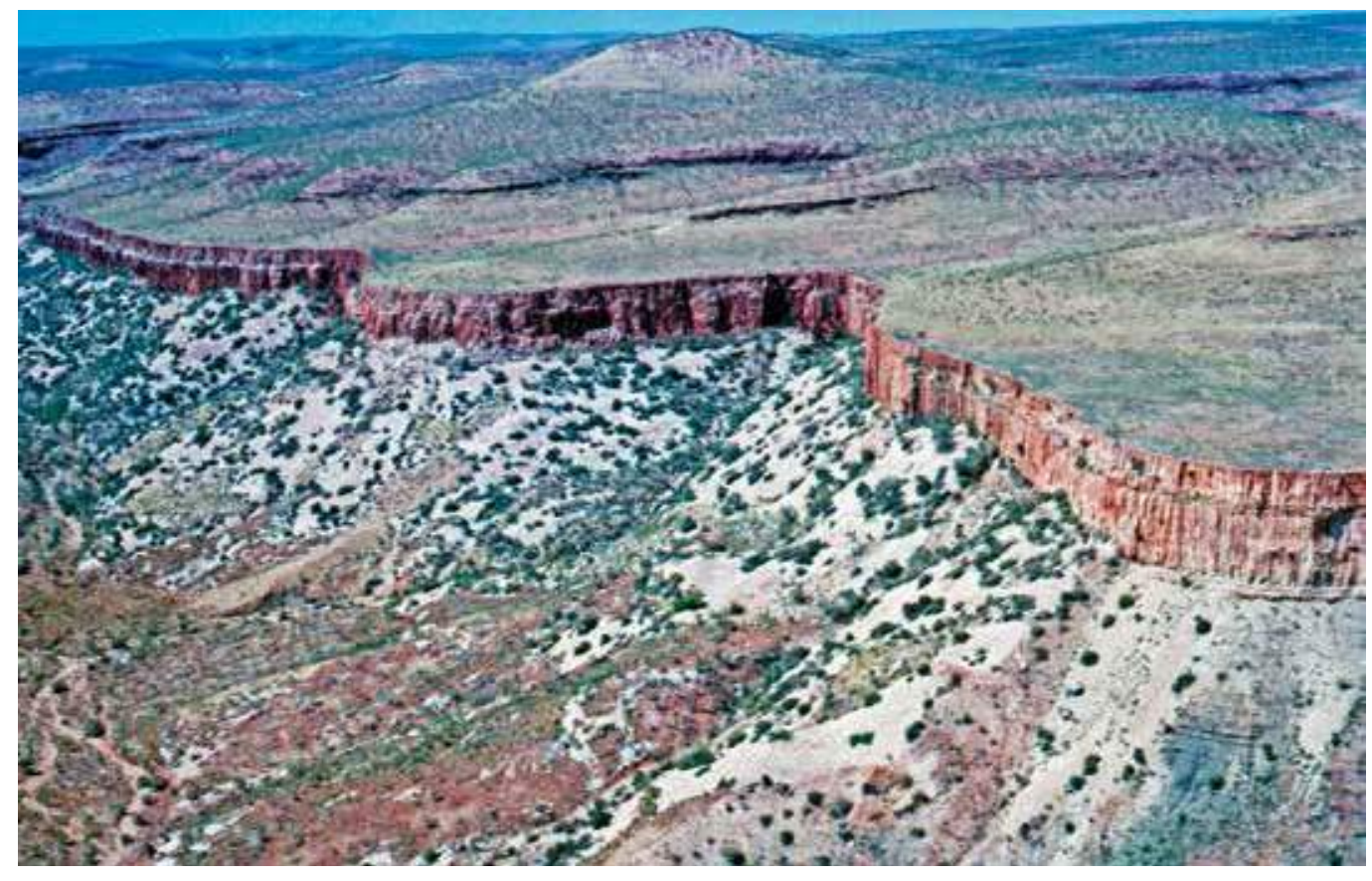

FIG. 18. Patchy monsoon rainforest on exposed scree slopes in the Cockburn Range, East Kimberley.

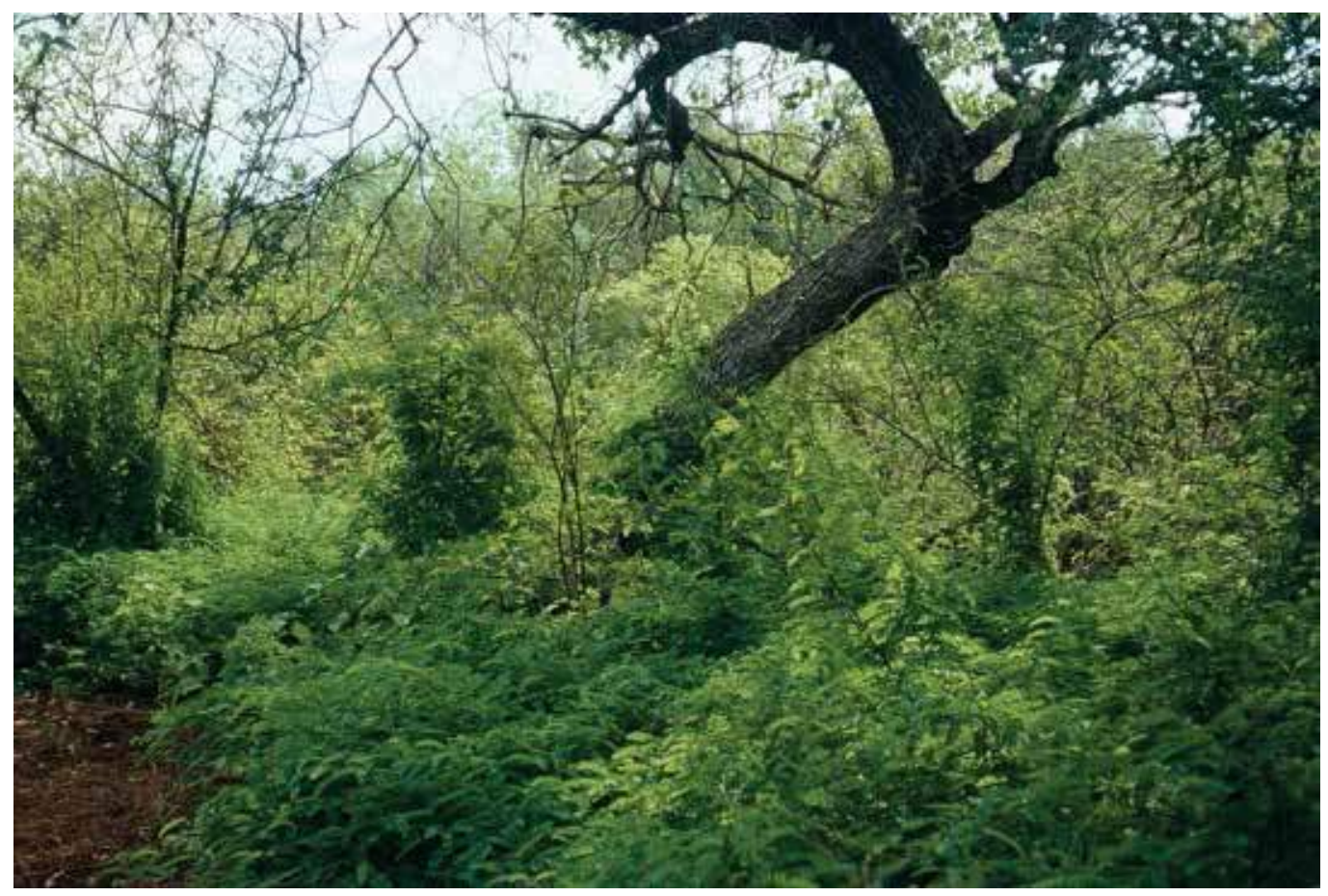

FIG. 19. Monsoon vine thicket near Broome on coastal dunes in wet season. Dominant vine is Crab's Eye Bean (Abrus precatorius). 


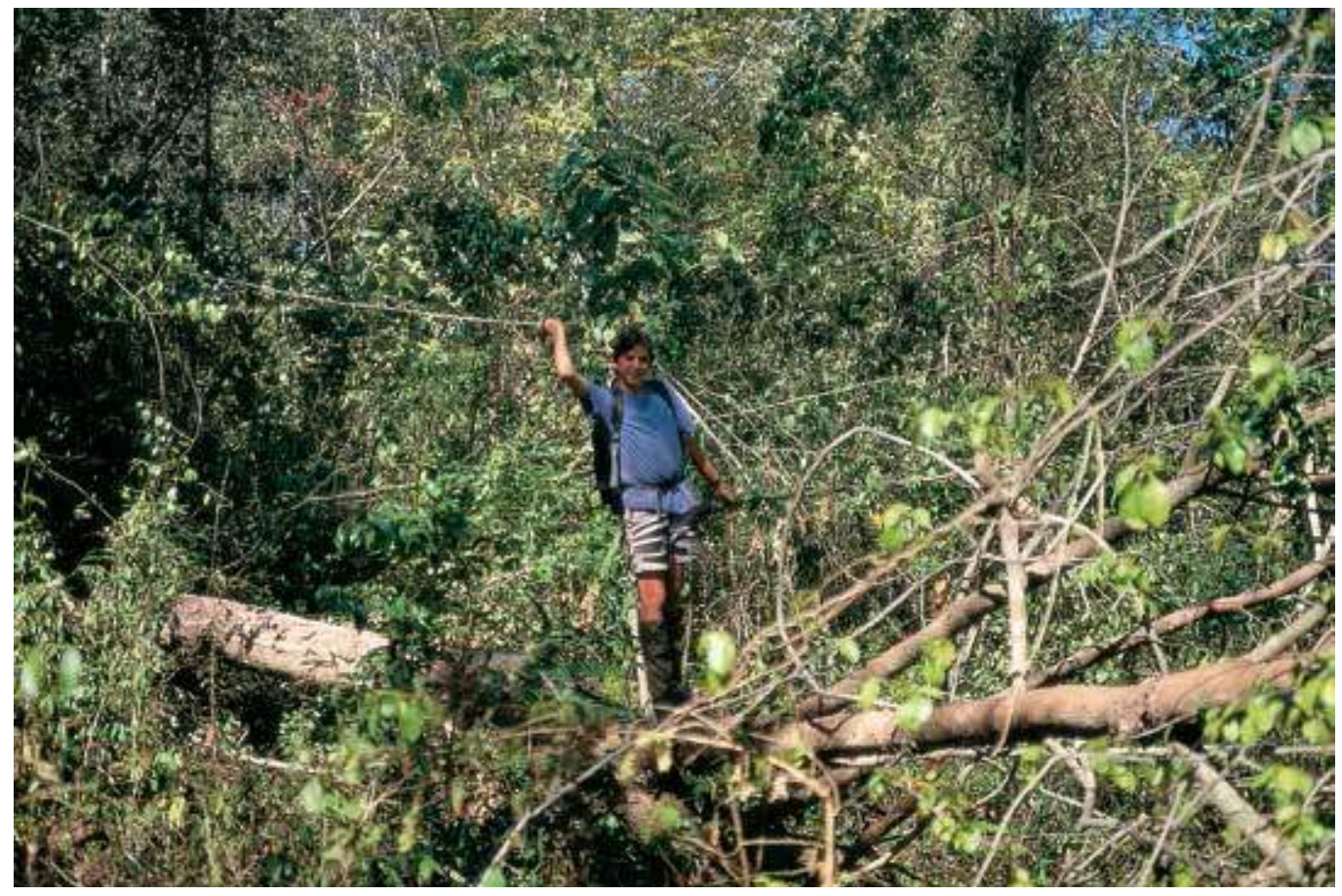

FIG. 20. Tony Raudino on a Landscope Expedition at'Lone Dingo' monsoon rainforest, Mitchell Plateau, showing fallen tree festooned with numerous vines.

Kimberley Plateau (Chappell \& Thom 1977). Pollen, mangrove clays, woods and organic muds from the Kimberley's north suggest extensive mangrove forests were established by $9000 \mathrm{yr}$ BP and were sustained until at least $6000 \mathrm{yr}$ BP, facilitated by increasing sea level, warmer postglacial temperatures and enhanced freshwater input from a more active monsoon (Jennings 1975; Thom et al. 1975; Proske et al. 2014). Pollen from the regions north also reflects woodland expansion at this time, with the occurrence of taxa dependent on moist soils suggestive of increased moisture (Proske et al. 2014).

Investigations by Field et al. (2017) at Black Springs, an organic mound spring in the northwest Kimberley indicates the Pleistocene-Holocene transition was a period of significant climatic and environmental change. During this time, the Australian summer monsoon has varied greatly in intensity, with an increase in monsoonal precipitation from -14,000 yr BP and pronounced drying in the late Holocene. Wetter and warmer conditions in general were experienced across tropical Australia in the early Holocene. Speleothem records from the southwest and eastern Kimberley also indicate wetter monsoon conditions in the early Holocene (Denniston et al. 2013a, 2013b). When local conditions became more mesic during the Pleistocene - early Holocene, rainforest species may have re-colonized the region from the Northern Territory, Queensland or Indonesian islands to the north via dispersal vectors such as frugivorous birds and bats. During the late Holocene, a less active monsoon may have caused rainforests to contract.

The Kimberley monsoon rainforests are part of a great corridor of monsoon forests extending through southeast Asia and into Australia that are important for the seasonal migration of birds such as the Common Koel (Eudynamys scolopacea) and the Channel-billed Cuckoo (Scythrops novaehollandiae). Fruit eating (frugivorous) birds such as the Rose-crowned Fruit-dove, Emerald Dove (Chalcophaps indica) and Pied Imperial Pigeon are nomadic in the Kimberley and move among the patches of monsoonal forest (Table 1). Frugivorous birds require many patches to maintain their populations (Price et al. 1999).

Almost all the plants, birds and non-camaenid land snails (snails that have expansive ranges with 
TABLE 1. Birds that rely on Kimberley monsoon rainforests or closed canopy communities.

\begin{tabular}{lll}
\hline Rainforest only & Rainforest and riverine forest & Rainforest and mangroves \\
\hline Rufous Owl & Oriental Cuckoo & Little Bronze Cuckoo \\
Australian Figbird & Brush Cuckoo & Mangrove Golden Whistler \\
Yellow Oriole & Common Koel & Wood Fantail \\
Cicadabird & Buff-sided Robin & Broad-billed Flycatcher \\
Spangled Drongo & & Shining Flycatcher \\
Rainbow Pitta & & Pied Imperial Pigeon \\
Orange-footed Scrubfowl & Rose-crowned Fruit-dove \\
Varied Triller & & \\
Little Shrike-thrush & & \\
Green-backed Gerygone & & \\
Green-winged Pigeon & & \\
Pied Imperial Pigeon & & \\
Rose-crowned Fruit-dove & & \\
\end{tabular}

geographic distributions extending outside the Kimberley region) recorded in Kimberley monsoon rainforests are also known from the Northern Territory and/or Queensland rainforests (Gibson et al. 2012). These include the majority of canopy trees that protect the rest of the community during the protracted dry season. The biogeographic affinities and lack of endemism in these taxa groups do not suggest prolonged isolation.

However, many of the small organisms are endemic to Kimberley monsoon rainforests, mainly those that are not readily dispersed by other species and have poor mobility. Examples include the majority of the camaenid land snails (Criscione \& Koehler 2014), earthworms, certain lizards, and a few small mammals and birds (Figs. 21-24).

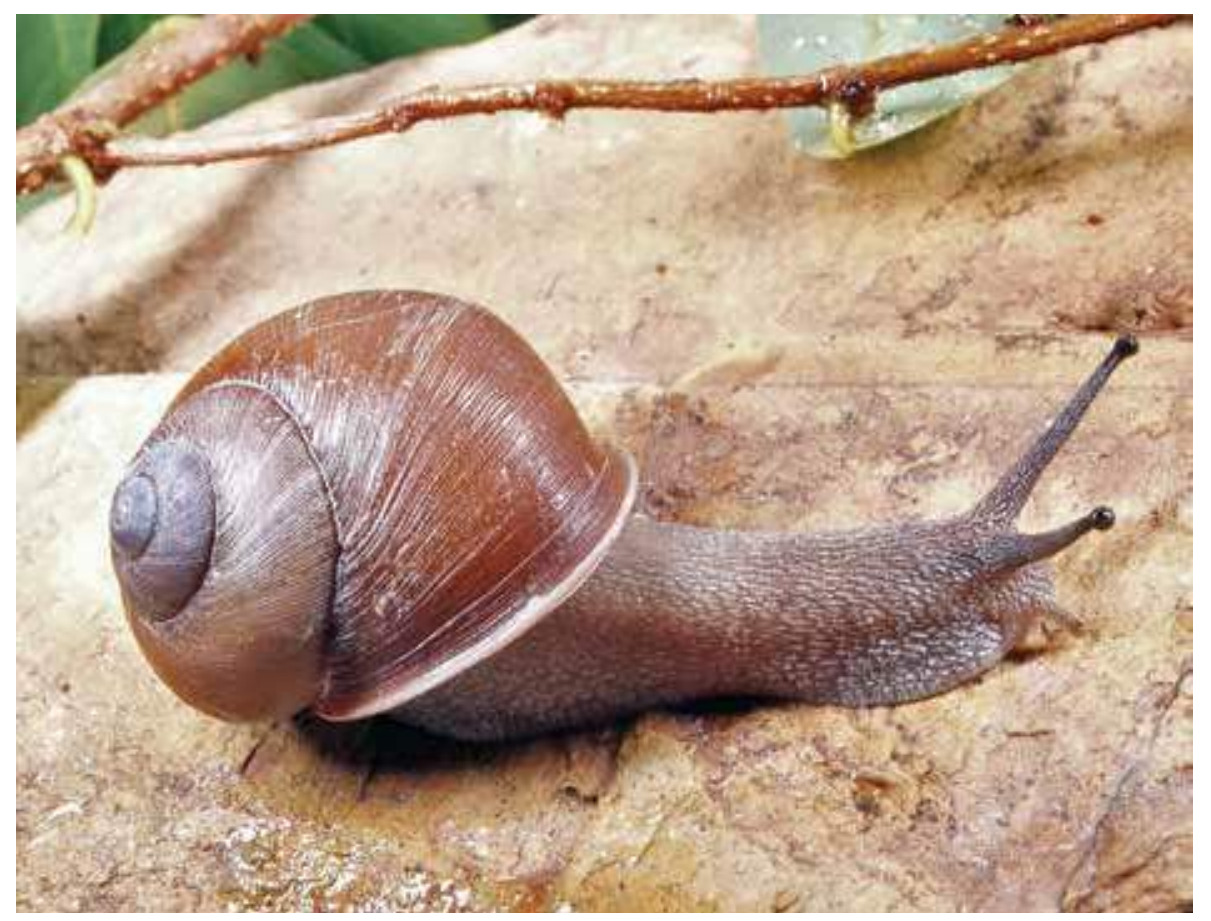

FIG. 21. Kimboraga exanima, Solem 1985. Family Camaenidae, in monsoon rainforest on St Andrew Island, St George Basin, Kimberley. Image —V. Kessner. 


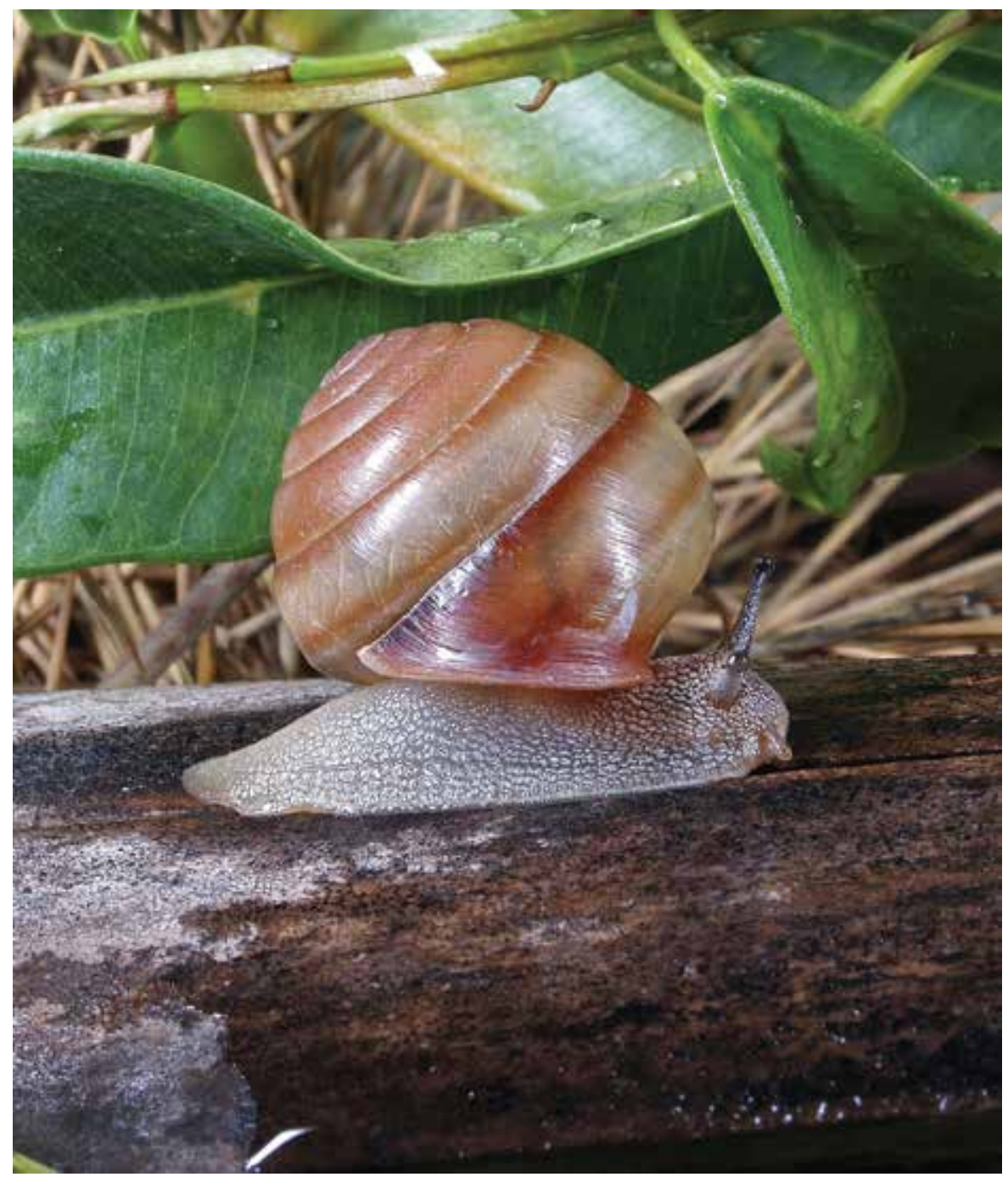

FIG. 22. Amplirhagada camdenensis, Köhler 2010. Family Camaenidae, a species endemic to monsoon rainforest on Augustus Island, Camden Sound, Kimberley. Amplirhagada represents the most species-rich genus of land snails in the world. Image-V. Kessner.

Köhler and Criscione (2013) attempted a molecular clock estimate for one camaenid Kimberley snail genus (Rhagada) and found the oldest two species lineages ( $R$. sheai and $R$. worora) may have originated 3.5 million years ago. The endemic species appear to have survived in Kimberley refugia associated with riverine, mangrove and/or sandstone habitats. For the snails, this process of fragmentation created an exceptional diversity with similar processes occurring in other groups of animals as well. For instance, the Buff-sided Robin (Pocilodryas cerviniventris) and the lizard Carlia johnstonei inhabit monsoon rainforest and riverine vegetation, the Lemon-breasted (Kimberley) Flycatcher (Microeca flavigaster) and the rodent Melomys burtoni are confined to the mangroves and monsoon rainforest, and the White-lined Honey-eater (Meliphaga albilineata) favors sandstone escarpments that are peripheral to rainforest patches (McKenzie et al. 1991).

Rainforest plants are species that can readily invade areas of suitable habitat because they have seeds that 


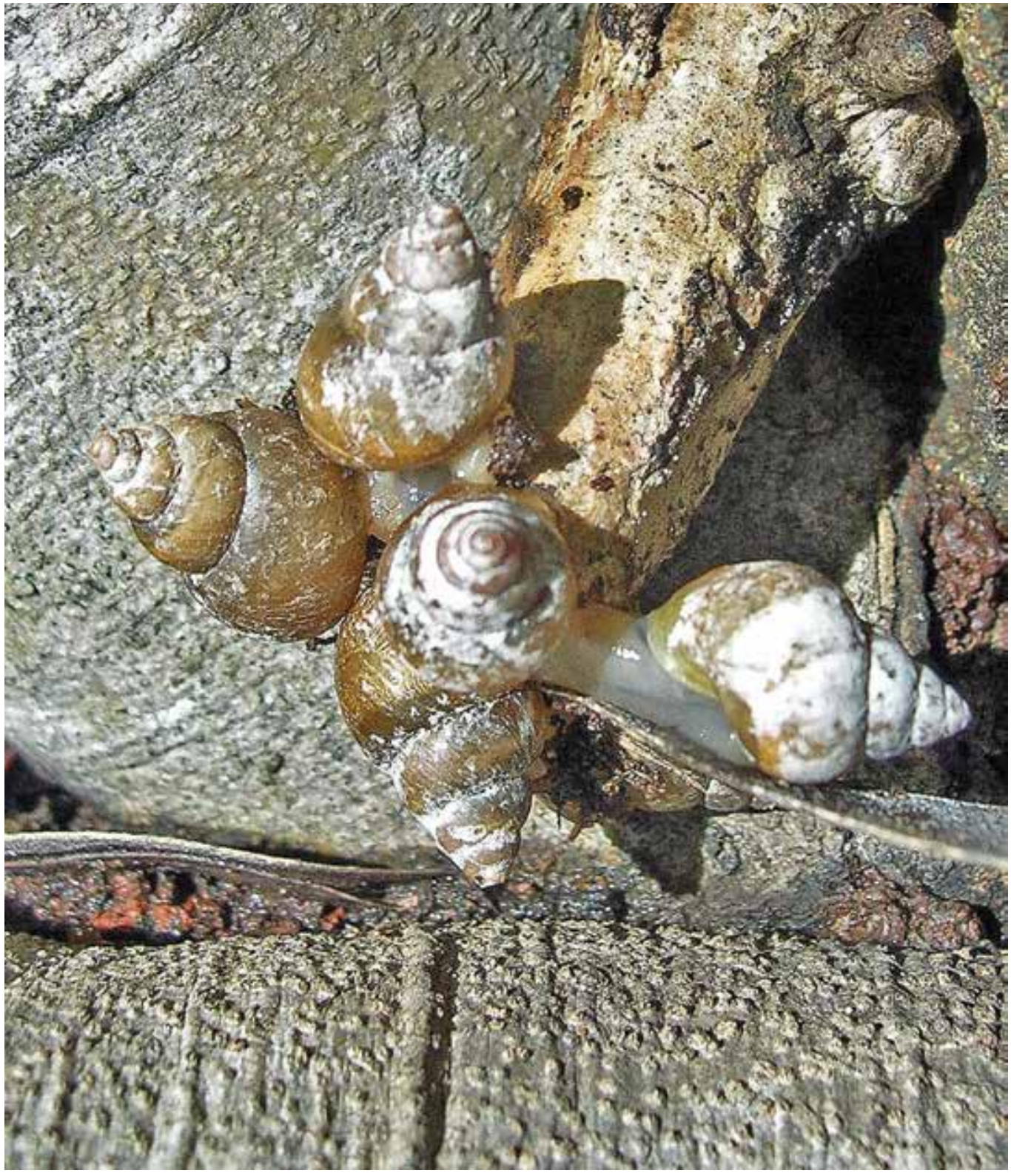

FIG. 23. Amimopina macleayi, Brazier 1876. Family Cerastidae, showing a group of mating non-camaenid snails in monsoon rainforest on Bigge Island, Kimberley. Image - V. Kessner.

are transported by birds and fruit bats. These plants can maintain their population in the isolated patches and even colonize new patches, to provide persistent as well as additional habits for animals (Fig. 25).

North Kimberley monsoon rainforest patches are typified by tall emergent crowns of tree species such as Aglaia elaeagnoidea, Albizia lebbeck*, Brachychiton* (B. diversifolius, B. xanthophyllus), Bombaxceiba*, Dysoxylum latifolium, Ficus* (F. congesta, F. geniculata var. insignis, F. hispida var. hispida, F. racemosa var. racemosa, F. 


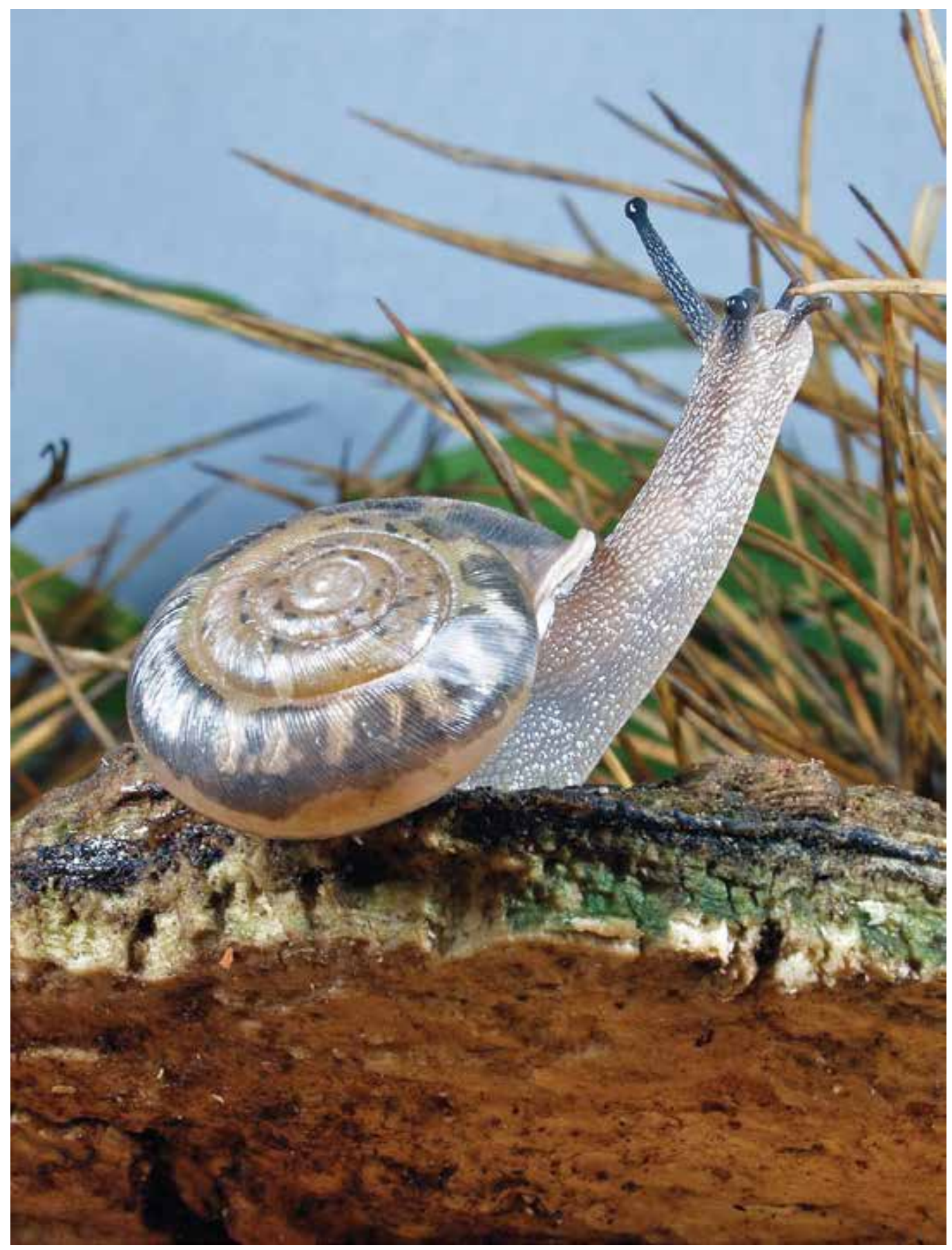

FIG. 24. Torresitrachia hartogi, Köhler 2011. Family Camaenidae, in monsoon rainforest on scree slopes on the islands of Buccaneer Archipelago, Kimberley. Image - V. Kessner. 


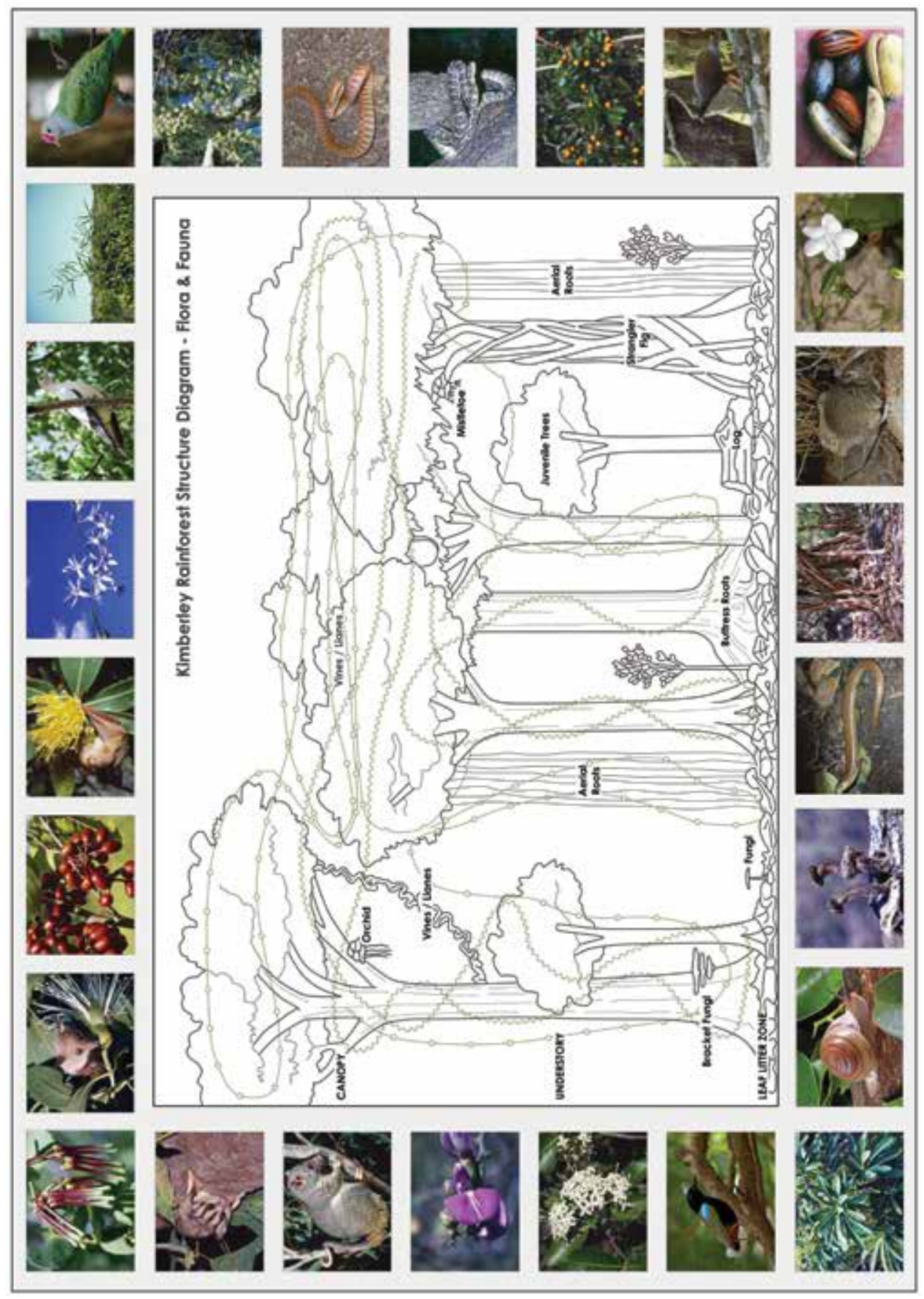

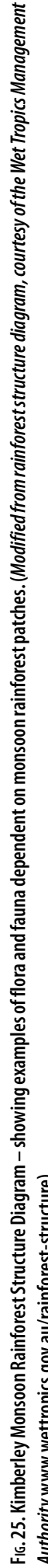


virens var. virens), Ganophyllum falcatum, Garuga floribunda*, Grewia breviflora*, Litsea glutinosa*, Miliusa brahei*, Mimusops elengi, Monoon australe, Myristica insipida, Sterculia quadrifida*, Terminalia* (T. ferdinandiana, T. microcarpa, T. petiolaris), Wrightia pubescens ${ }^{*}$, and Ziziphus quadrilocularis*, reaching to more than 15-20 +meters in height (* indicates deciduous or semi-deciduous during the dry season). The profile of the canopy is characteristically very irregular in height and appears to consist (in the Wet Season) of vine foliage as much as tree foliage. The understory is dominated by small trees and shrubs such as Alectryon kimberleyanus, Denhamia obscura, Glycosmis (G. microphylla, G. trifoliata), Grewia glabra, Micromelum minutum, Murraya paniculata, Strychnos lucida, and Trema tomentosa. Common edge species include Acacia holoserica, the Boab (Adansonia gregorii), Helicopter Tree (Gyrocarpus americanus), and Antidesma ghaesembilla.

Only one epiphyte, a tree orchid (Dendrobium affine), has been recorded from the northern Kimberley monsoon rainforests. This species also occurs in the Northern Territory but is not known to occur in Queensland. However, the Channel-leaved Tree Orchid (Cymbidium canaliculatum) occurs only in the coastal monsoon vine thickets of the Dampier Peninsula. It is the most xerophytic orchid with thick leaves that resist desiccation. It grows in branch and tree hollows resulting from termite and fungal attack. The plants have an extensive root and rhizome system which extends deep into decaying heartwood in the host tree and may reappear from other hollows meters away from original clump. Dixon (2002) considers that it is not a "true" epiphytic orchid as it requires composted material for its growth. The hemi-parasitic mistletoe (Amyema benthamii) and the hemi-parasitic Love Vine (Cassytha filiformis) occur on a variety of host species.

Creepers, vines and lianas (woody vines) are abundant in the canopy and make up a significant proportion of rainforest vegetation. Despite their obvious importance in the rainforest flora, the ecology of vines and lianas in Kimberley monsoon rainforests is poorly understood. Vines form impenetrable tangles with many having adaptations that enable them to climb into the canopy. Modifications include prickles, spines or hooks (Asparagus, Caesalpinia, Capparis, Luvunga, Senegalia, and Smilax); tendrils (Adenia, Ampelocissus, Cayratia, and Cissus); modified tendrils (Clematis and Flagellaria) and stem twiners or scramblers (Aristolochia, Canavalia, Cassytha, Grewia, Meiogyne, Miliusa, Pachygone, and Tinospora). Other adaptations include pods with irritant hairs (Mucuna diabolica subsp. kenneallyi) or stems that exude a milky exudate such as the Fire Vine (Trophis scandens) that can cause painful "burns" or dermatitis on skin contact.

During the wet season, the abundant vine foliage envelops the canopy of the trees, effectively reducing sunlight and increasing humidity. Vines and lianas often begin life on the ground as small self-supporting shrubs and rely on other plants to reach the light-rich environment of the upper canopy. Upon reaching the canopy, vines and lianas spread from tree to tree. This creates important pathways for canopy-dwelling animals. Vines and lianas produce abundant leaves, flowers and fruits that provide food resources for animals as well as producing abundant flowers, making them important for pollinators. Bright, fleshy fruits and their consumption by a variety of animals is a distinctive feature of the wet tropics rainforests (Figs. 26-68).

The understory consists of low trees, shrubs and vines. There is virtually no ground flora apart from young seedlings. Leaf litter is seldom more than $2-3 \mathrm{~cm}$ thick. Many forms of fungi (wood rotters, mycorrhizal etc.) occur in the rainforest, with fruiting bodies often appearing in the wet season (Figs. 69-72). Of the other non-vascular plants, the bryophytes (mosses, liverworts, hornworts) and lichens are poorly known and described from Kimberley monsoon rainforests. Almost all of the specimens are corticolous, recorded living or growing on the bark of rainforest trees and shrubs. Bryophytes collected from patches on the Mitchell Plateau include the liverworts (Frullania ericoides, F. falciloba, F. probosciphora, F. squarrosula, and Riccia multifida) and the mosses (Calymperes tenerum, Fissidens brassii var. hebetatus, F. curvatus var. curvatus, Octoblepharum albidum, and Trachyphyllum inflexum). Lichens recorded include Anisomeridium americanum, Collema coccophorum, Graphis sp., Hemithecium implicatum, Lithothelium nanosporum, Melanelia fuscosorediata, Pyrenula nitida, and Pyxine cocoes. Ferns are rarely encountered in Kimberley monsoon rainforest with the Oak-leaf Fern (Drynaria quercifolia), Maidenhair Ferns (Lygodium flexuosum and L. microphyllum) and Swamp Climbing Fern (Stenochlaena palustris) more typically found growing in moist sandstone gorges and swamp forest that support rainforest tree species.

Not every monsoon rainforest patch contains the same suite of species; some species are very restricted or 


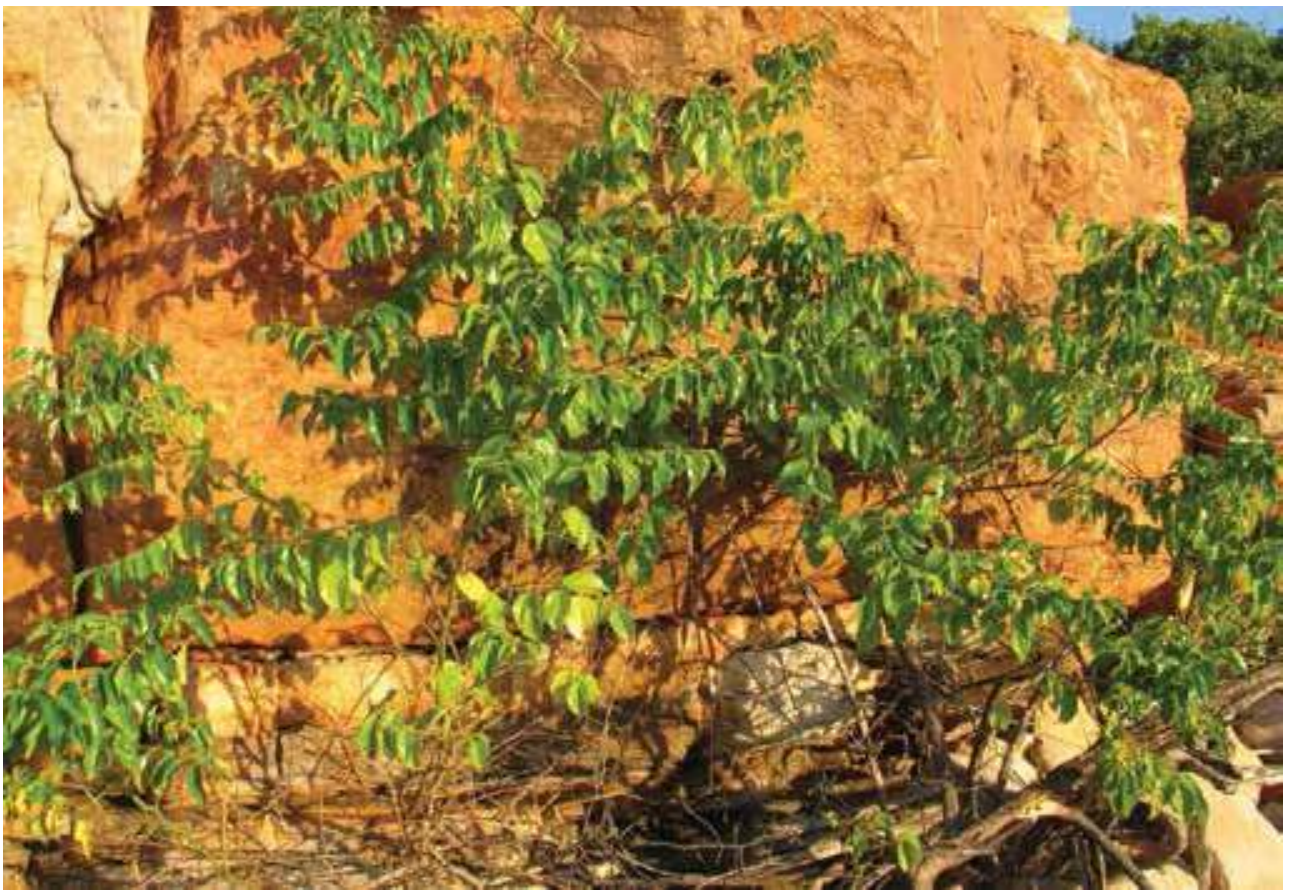

FIG. 26. Beach Berry Bush (Colubrina asiatica), a widespread species across N. Australia, also New Guinea. Image-T. Willing.

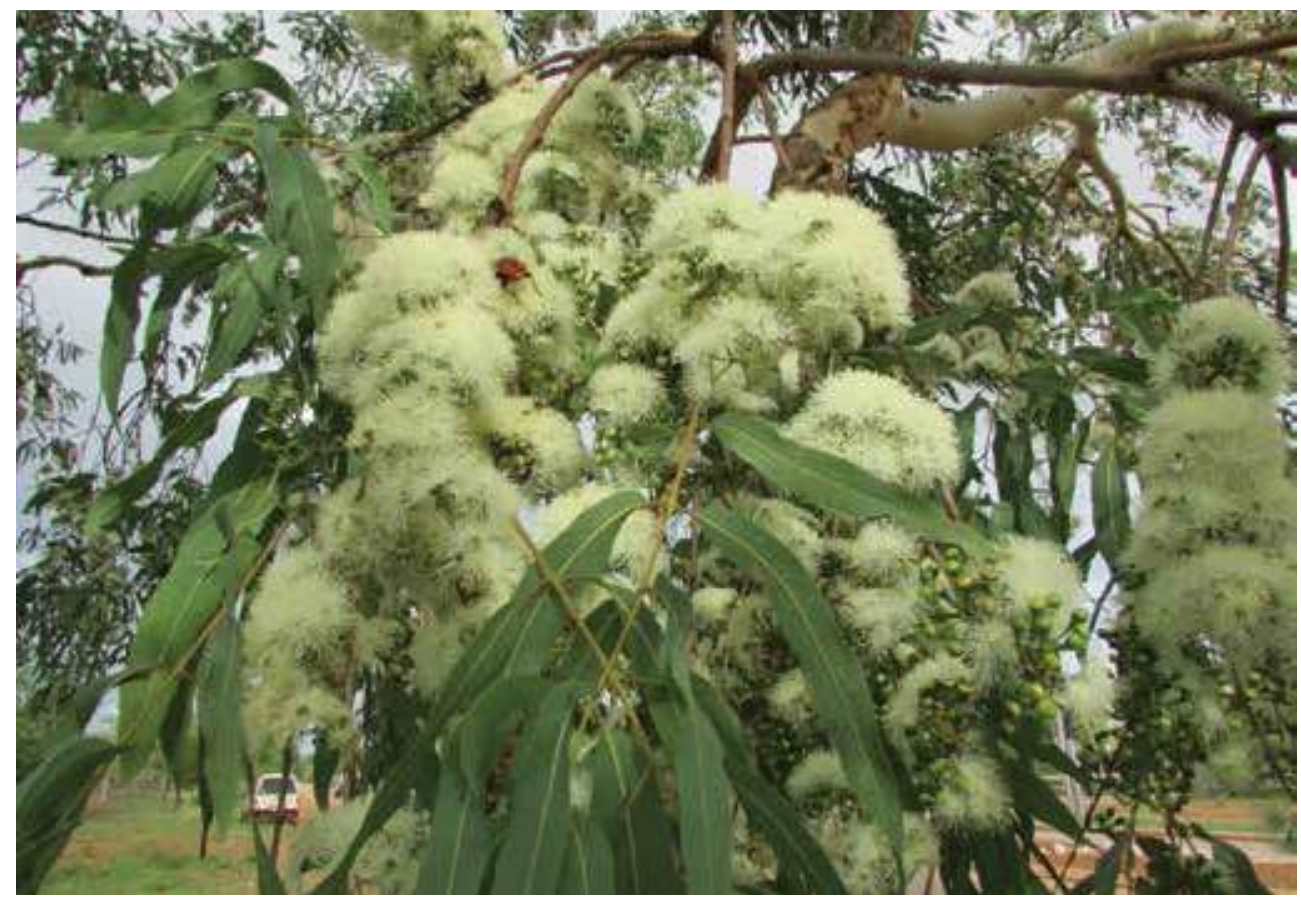

Fig. 27. Cable Beach Ghost Gum (Corymbia paractia), an endemic species restricted to the Cable Beach area at Broome. Image-T. Willing. 


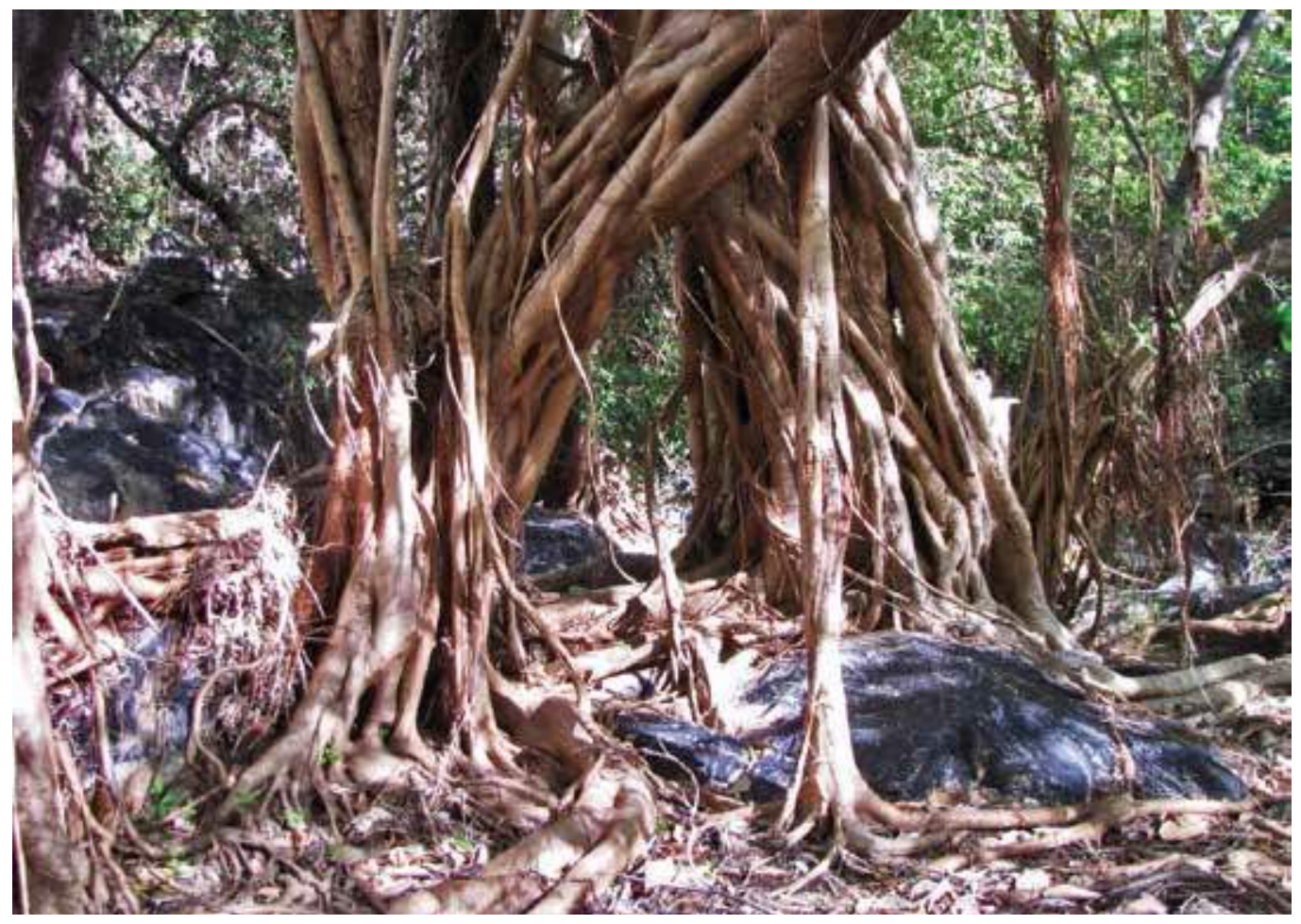

Fig. 28. Banyan Fig (Ficus virens), showing aerial and strangling roots. Widespread in monsoon rainforests across N. Australia, also Asia and Malesia. Image-T. Willing.

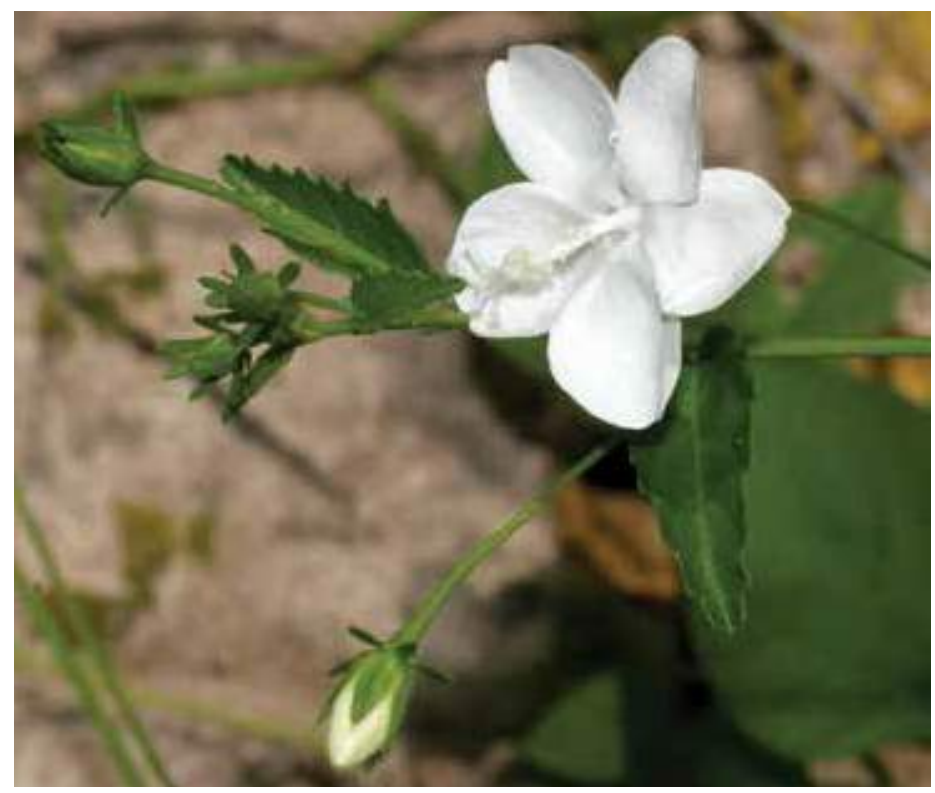

FIG. 29. Monsoon Hibiscus (Hibiscus peralbus), an endemic species restricted to Kimberley monsoon rainforests. Image—Russell Barrett. 


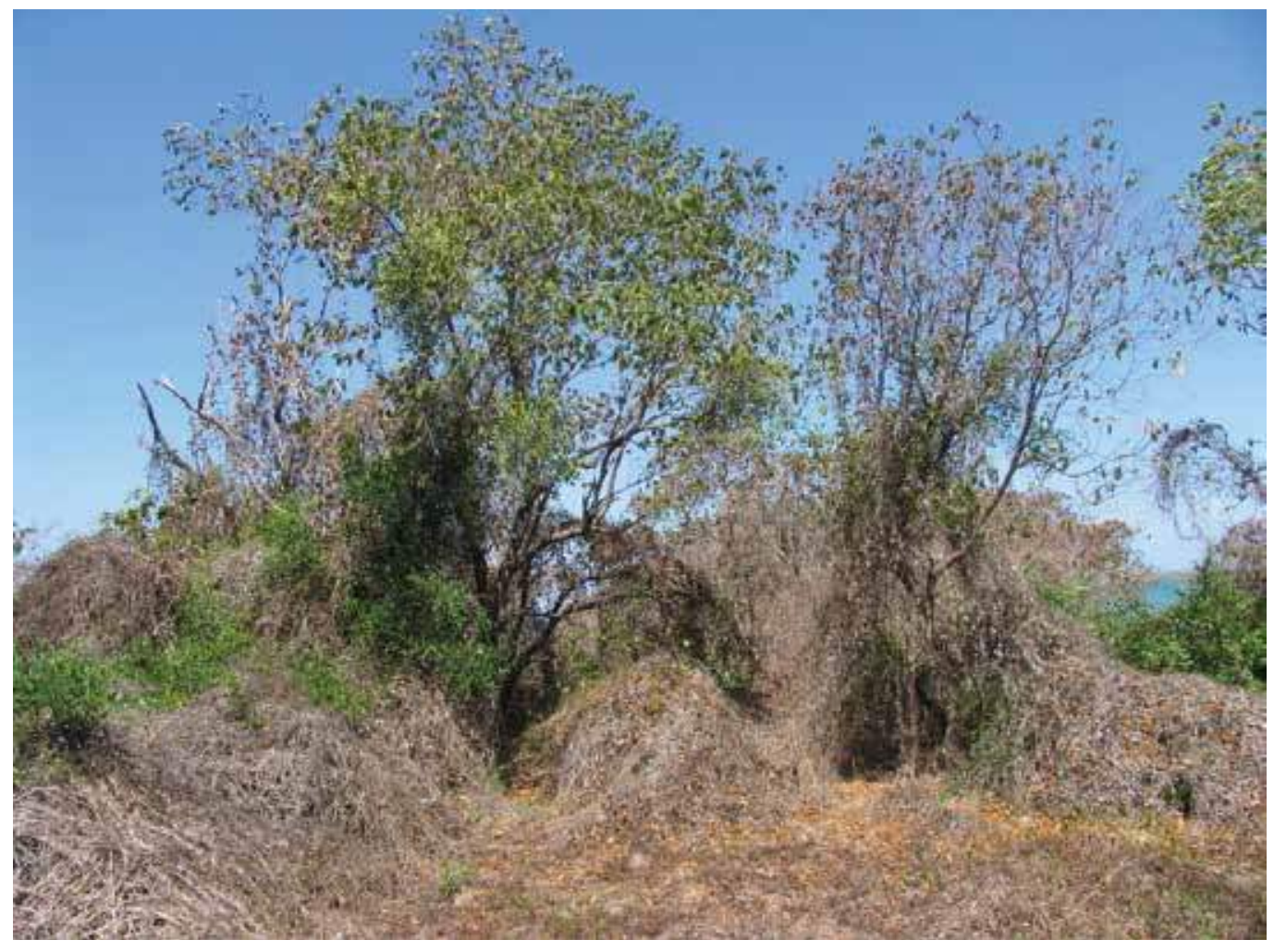

FiG. 30. Loofah Vine (Luffa saccata), on Marool (Terminalia petiolaris). Image-T. Willing.

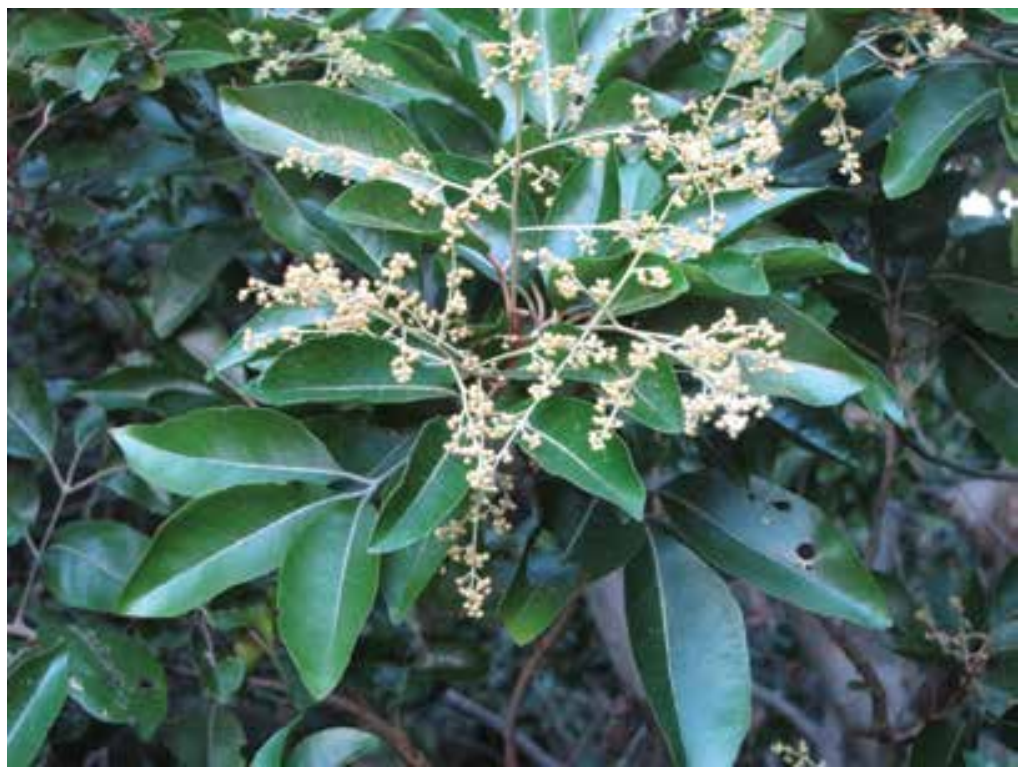

FIG. 31. Droopy Leaf (Aglaia elaeagnoidea), occurs in Kimberley, Cape York and Queensland, also India, Asia, Malesia, Taiwan and New Caledonia.

This document is intended for digital-device reading only. 


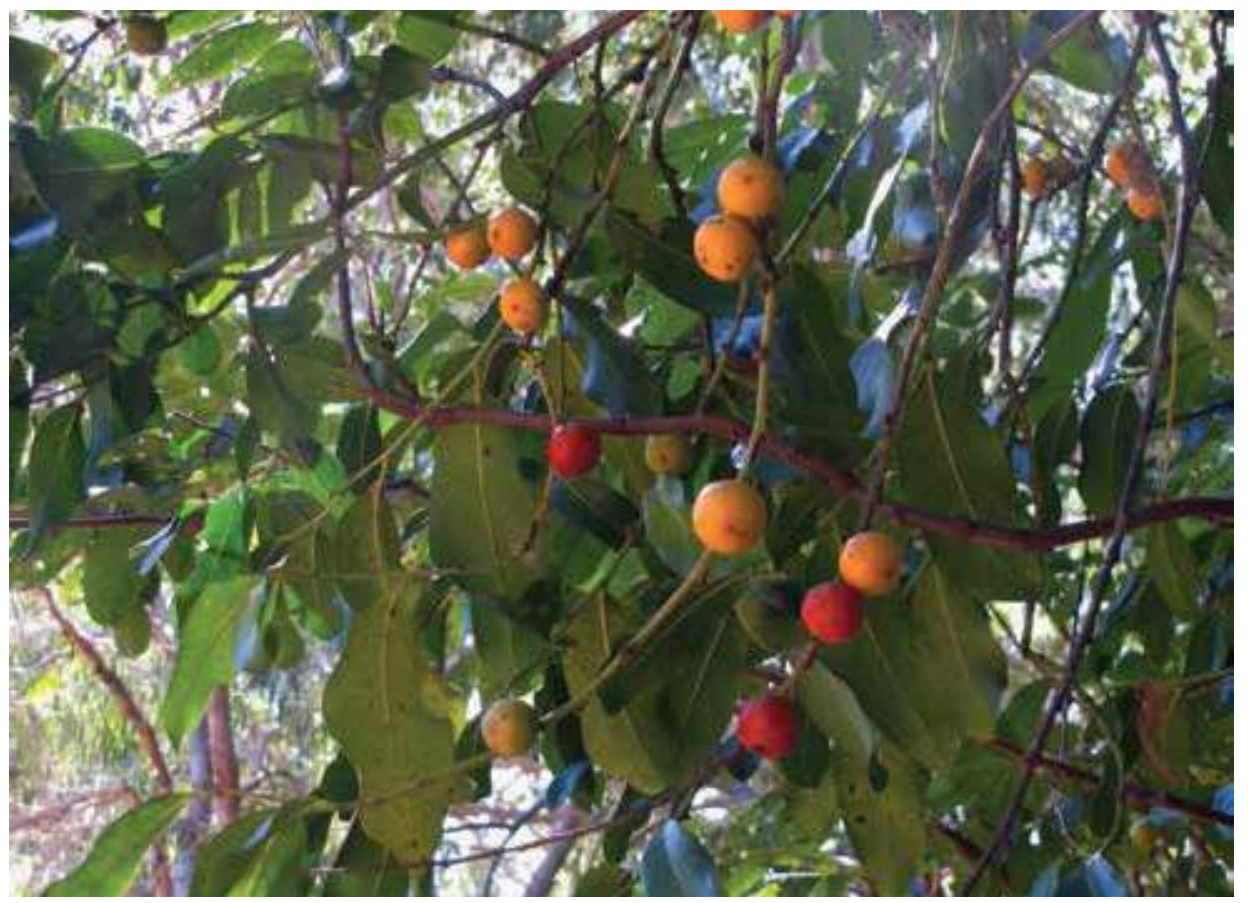

FiG. 32. Broad Leaved Ebony (Diospyros maritima), widespread across N. Australia, also Asia and New Guinea. Image-T. Willing.

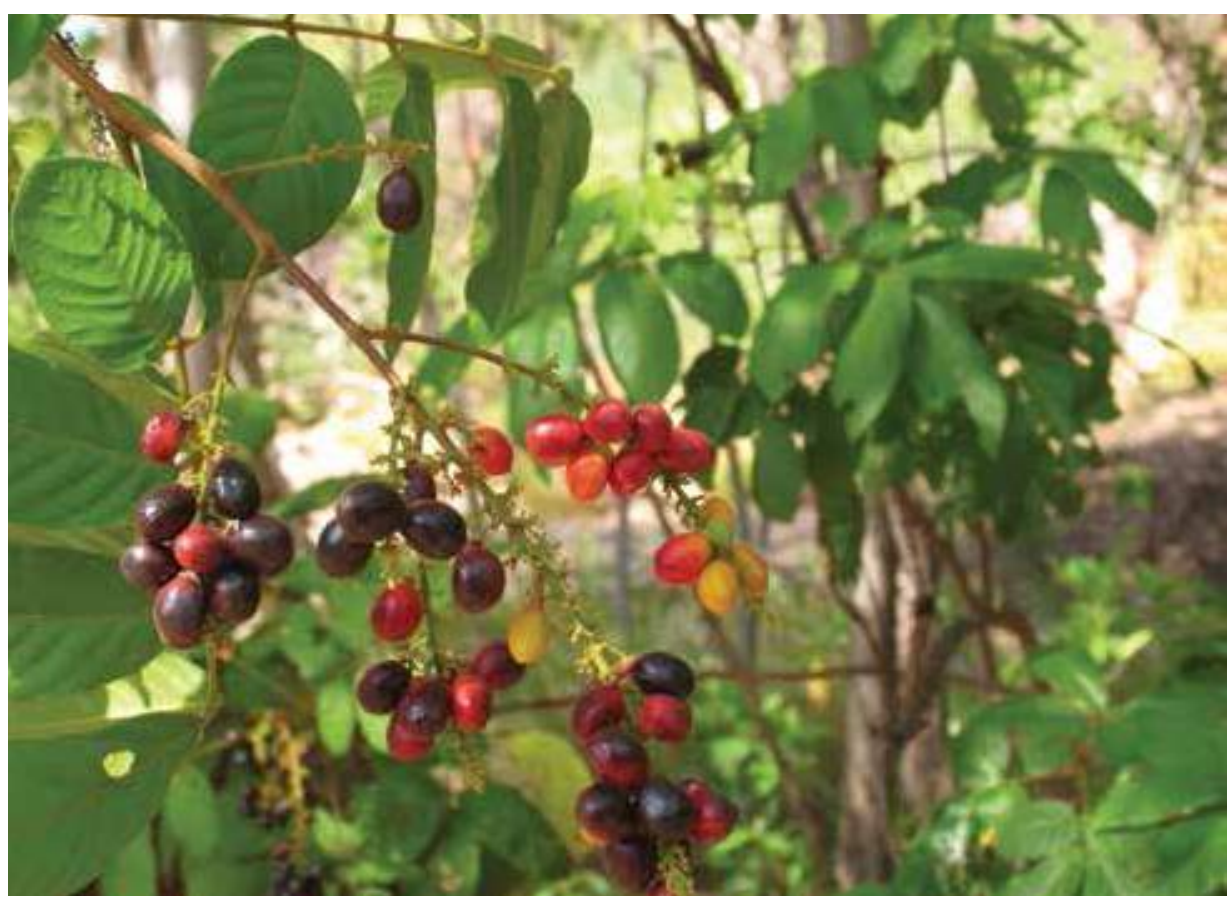

FIG. 33. Lepisanthes rubiginosa, in Australia only recorded from Kimberley monsoon rainforests, also Asia and Malesia. Image-T. Willing. 


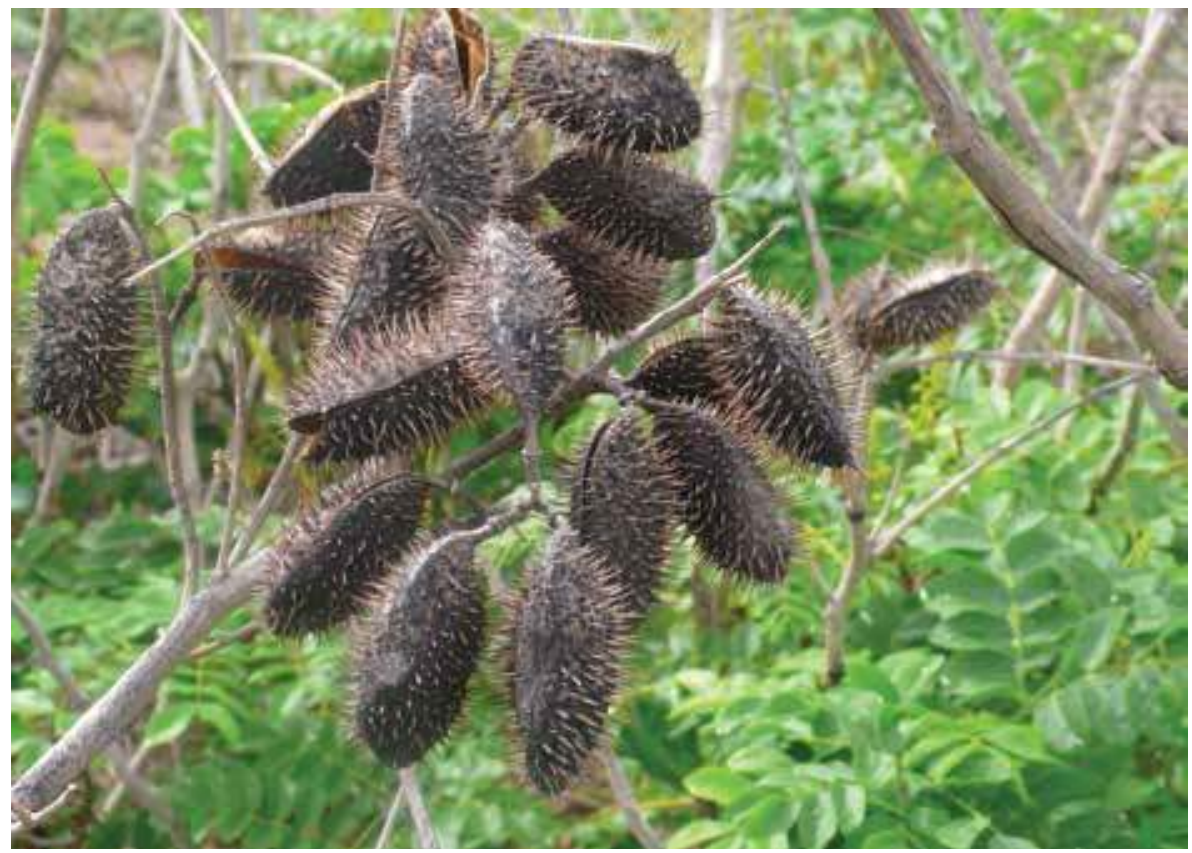

FiG. 34. Goolyi (Caesalpinia major), vine, seed pods, only found in N. Australia.

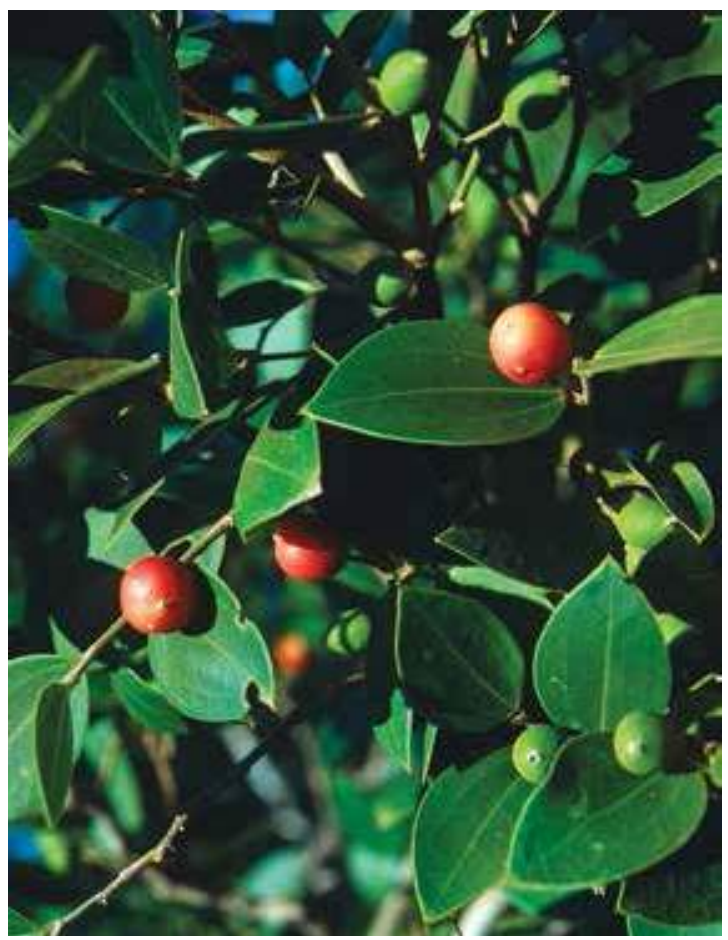

FIG. 35. Goonj (Celtis philippensis), widespread in N. Australia, also Americas, Madagascar, Malesia, Pacific Islands.

This document is intended for digital-device reading only.

Inquiries regarding distributable and open access versions may be directed to jbrit@brit.org. 


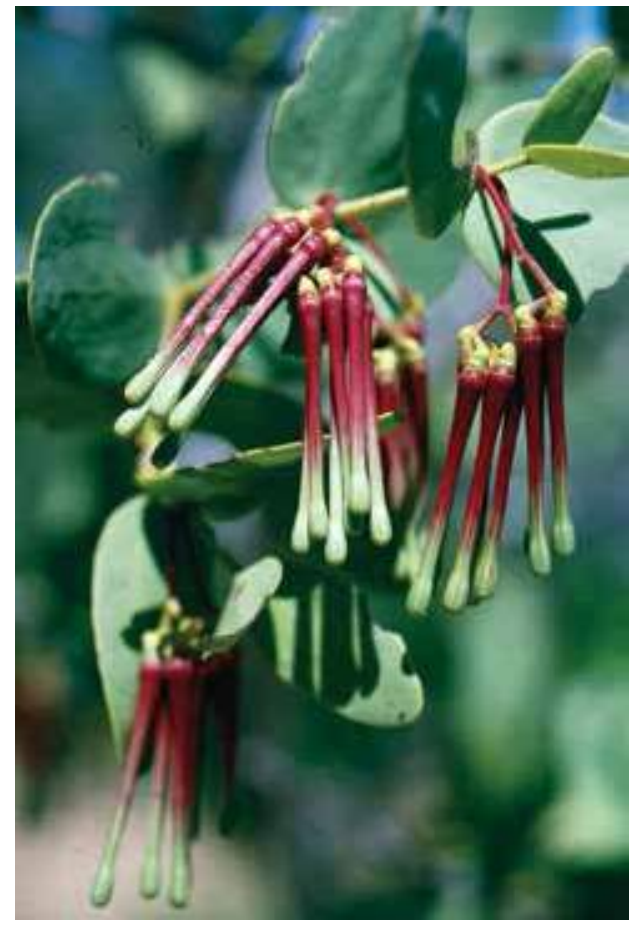

FIG. 36. The mistletoe Nyilinyil (Amyema benthamii), occurs in WA and Northern Territory. Image —B. Carter.

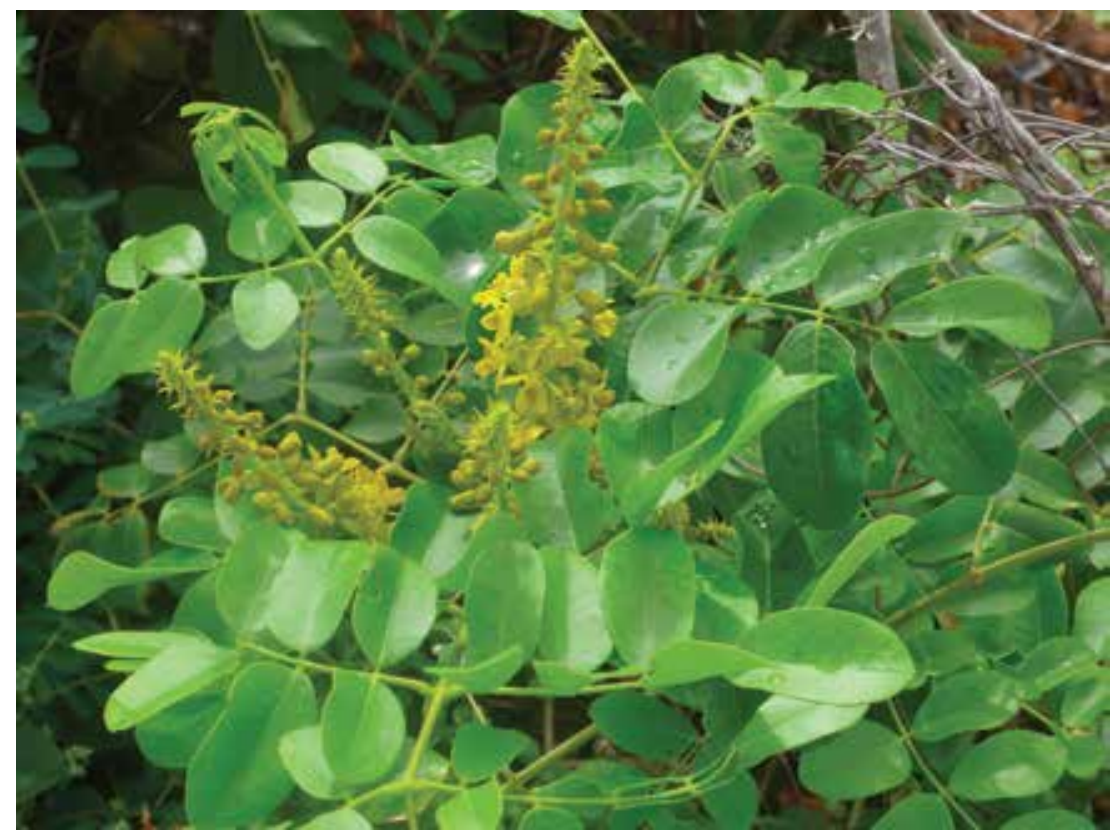

FIG. 37. Goolyi (Caesalpinia major), flowers. In Australia only found in Kimberley. Also occurs in the Americas, Madagascar, Asia, Malesia, and the Pacific Islands. 


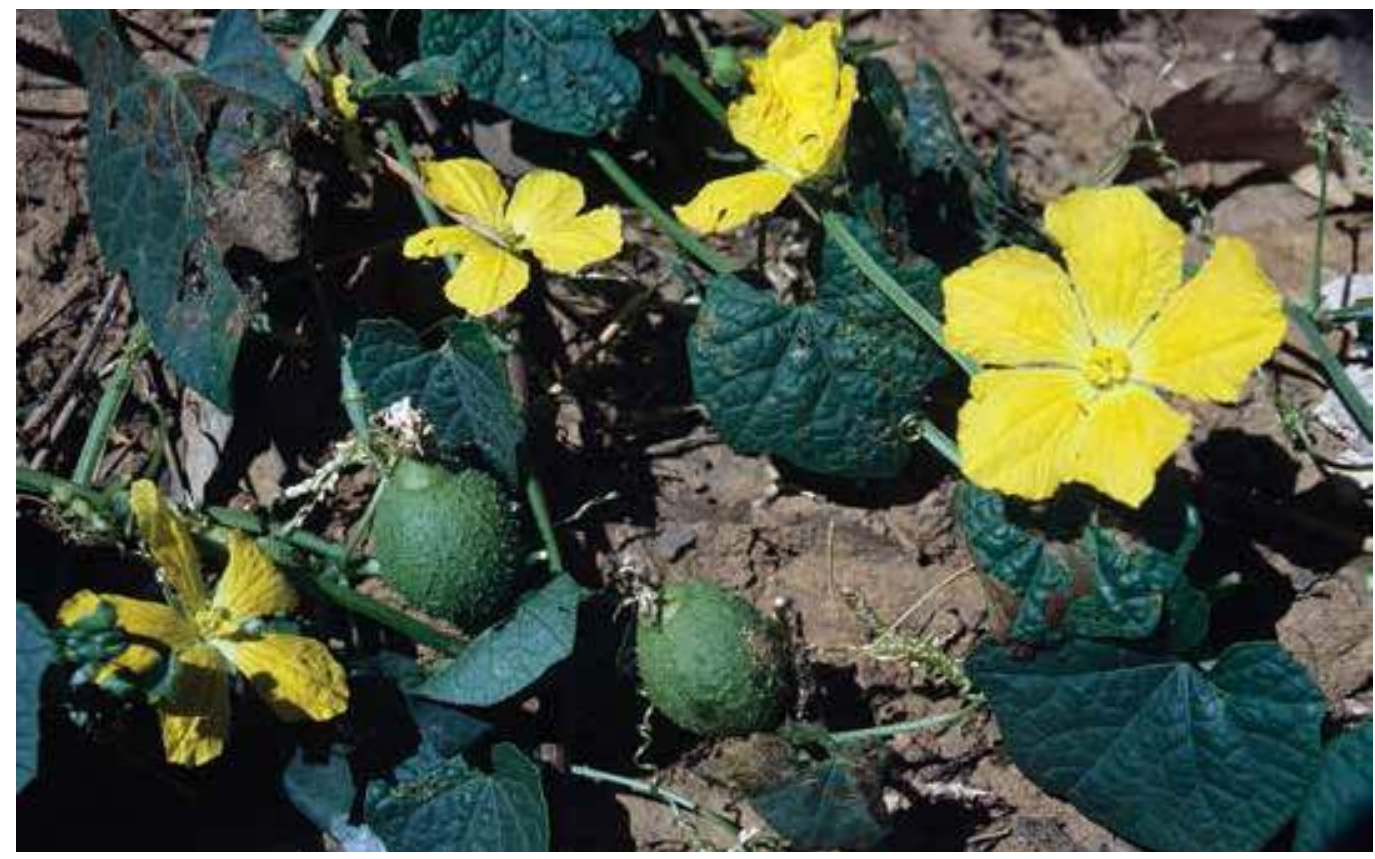

FiG. 38. Loofah Vine (Luffa saccata), an Australian endemic, widespread in the Kimberley, Western Australia and the adjacent north-western Northern Territory, with a disjunction to the McArthur River area of the Northern Territory. Image-T. Willing.

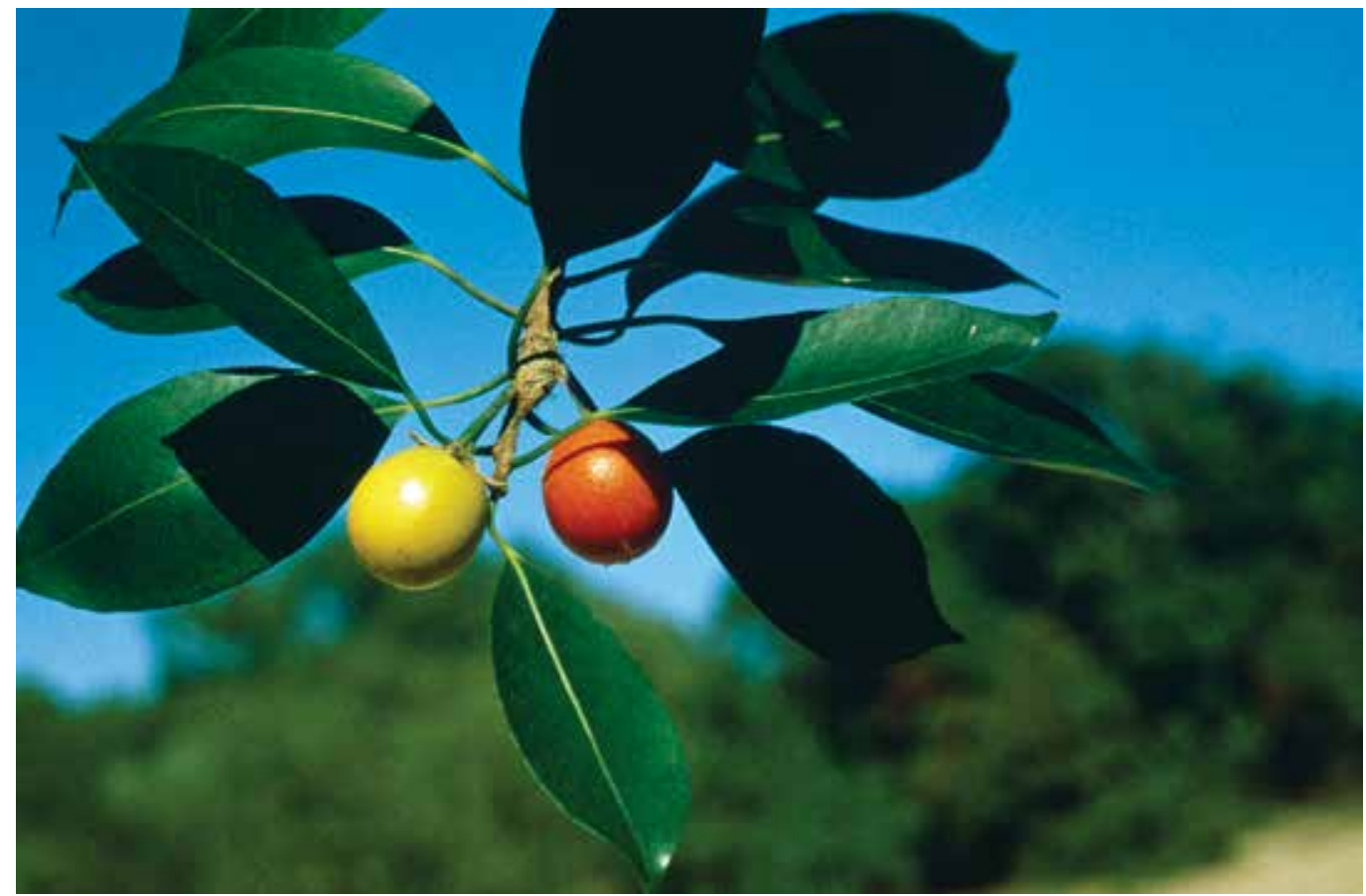

FIG. 39. Mamajen (Mimusops elengi), widespread in monsoon rainforest across northern Australia. 


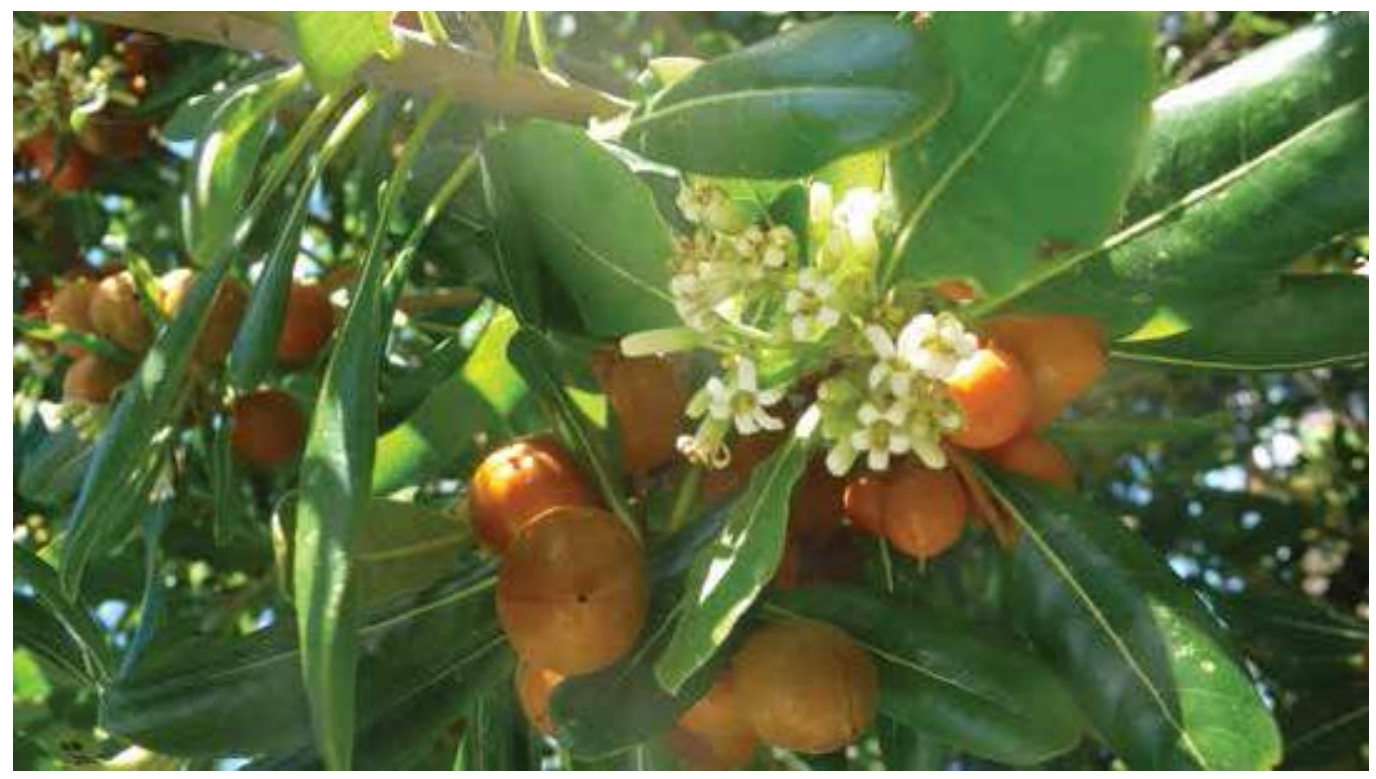

Fig. 40. Pittosporum moluccanum, a species restricted to coastal beach monsoon rainforests in Kimberley, also Northern Territory, NE Queensland and Asia.

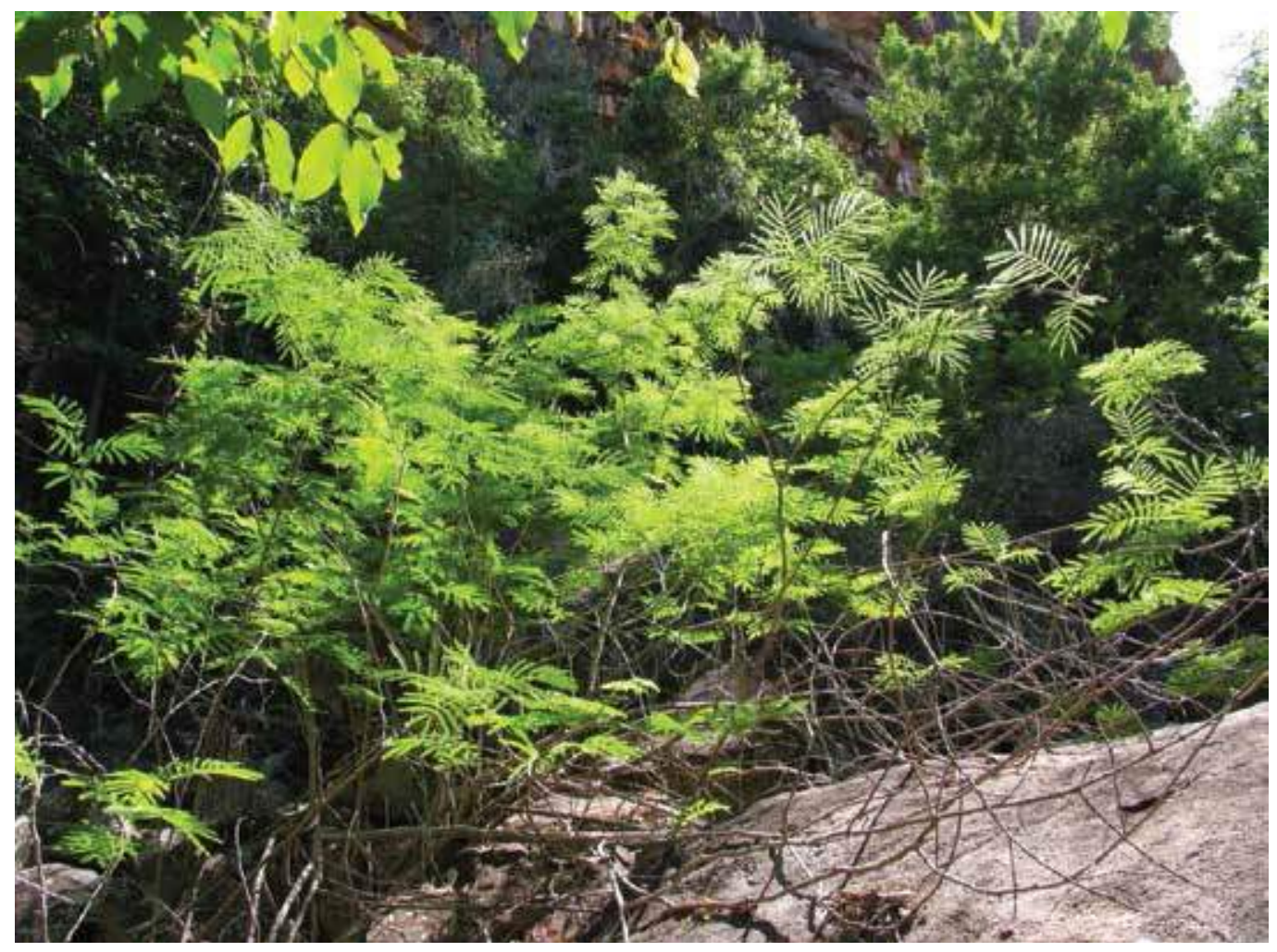

FIG. 41. Climbing Wattle (Senegalia albizioides), vine, a new generic record for Western Australia, also Cape York, Queensland. Image-T. Willing. 


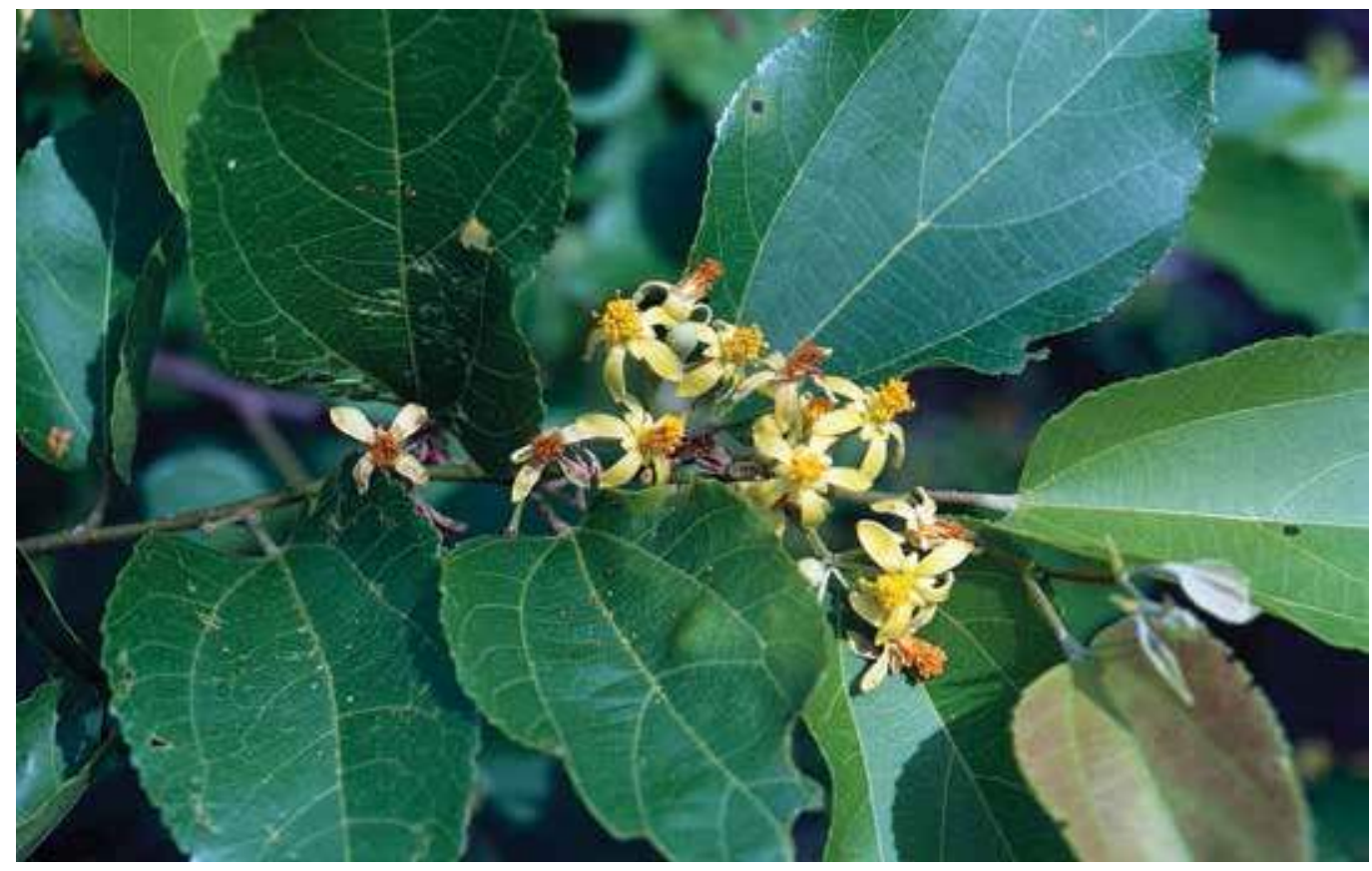

Fig. 42. Goolmi, Currant or Coffee Bush (Grewia breviflora), flowers, widespread in northern Australia, also Northern Territory, Cape York, Timor and New Guinea.

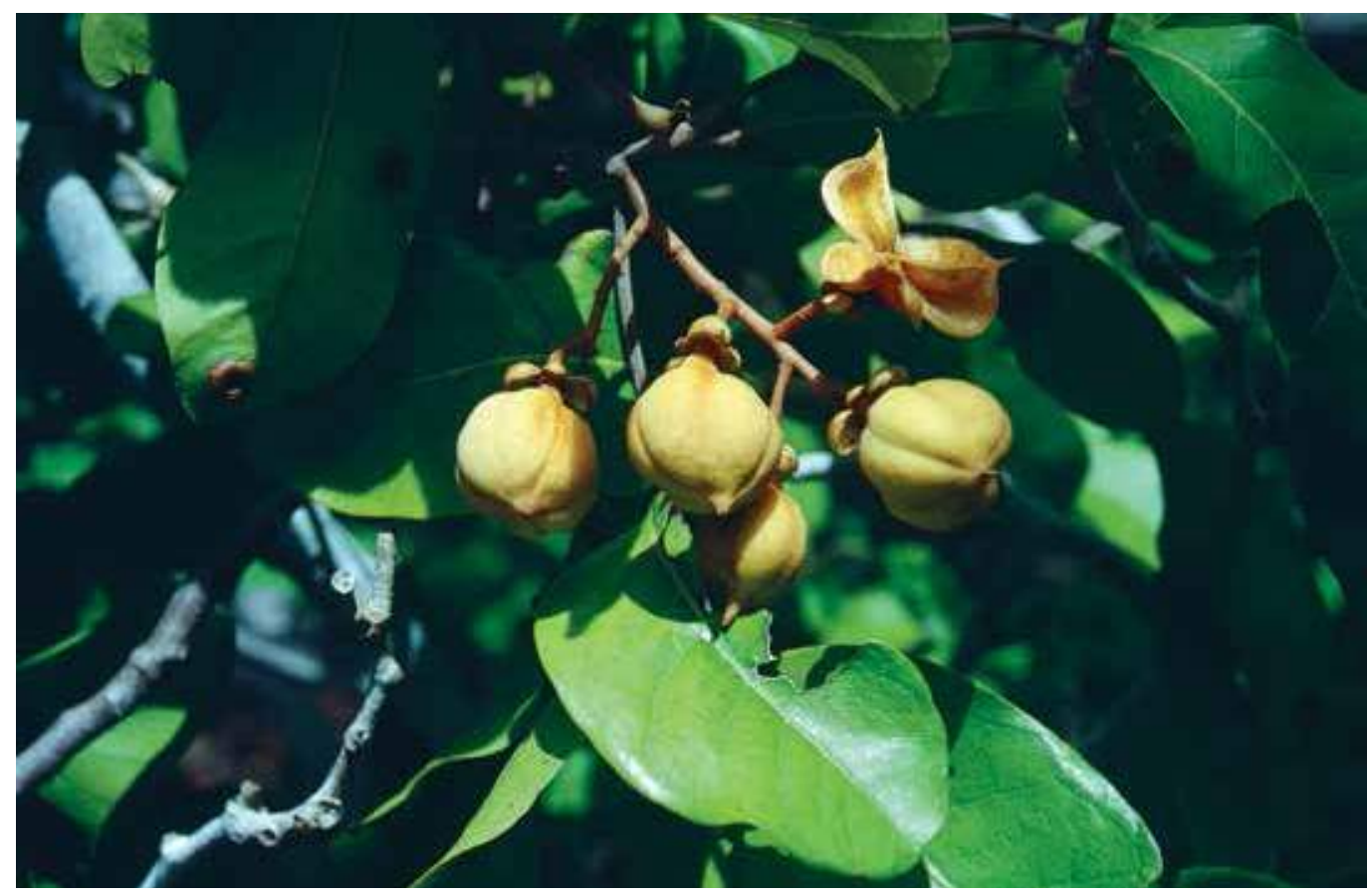

FIG. 43. Tuckeroo (Cupaniopsis anacardioides), endemic to northern Australia. 


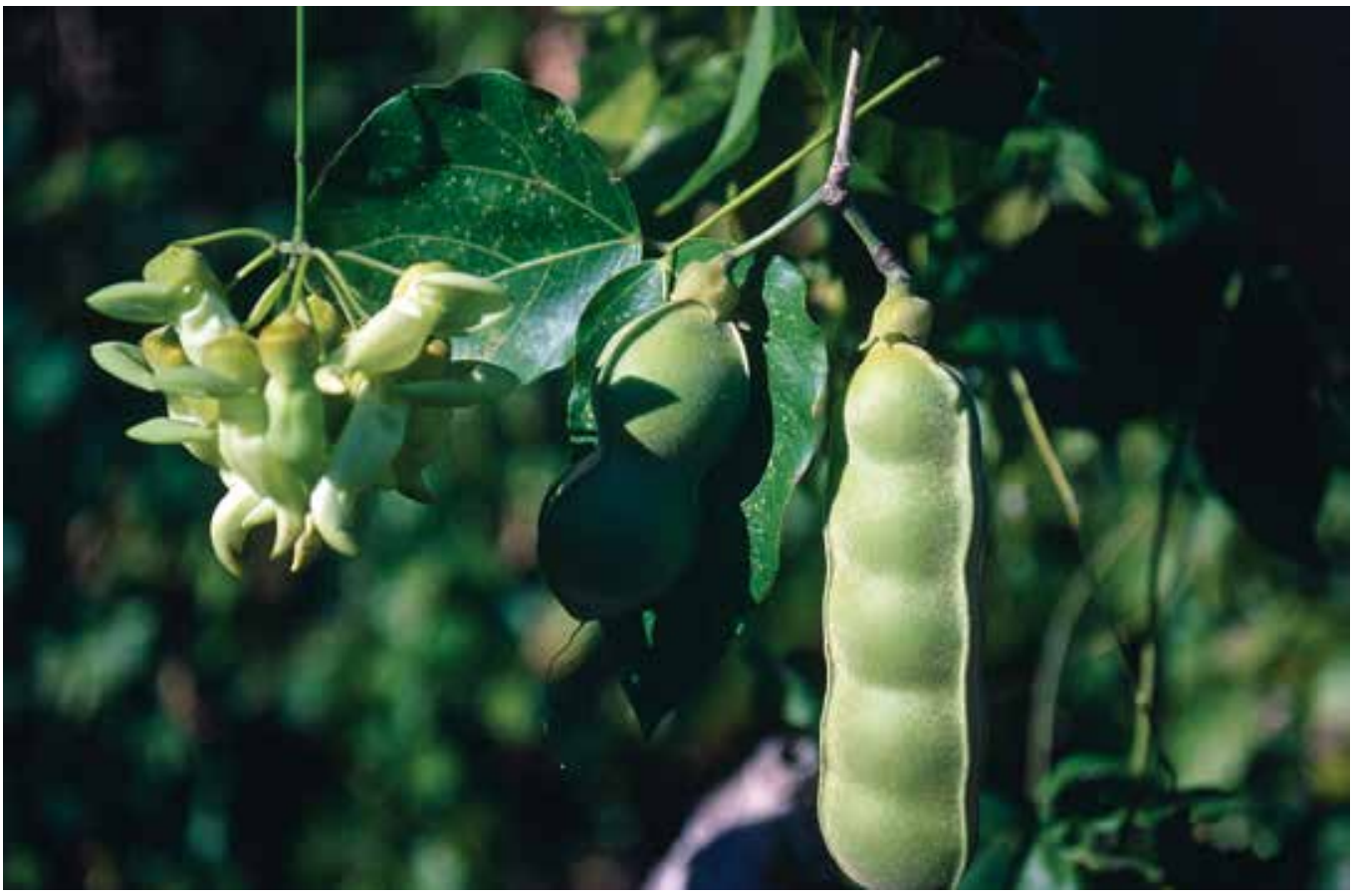

FIG. 44. Black Bean (Mucuna gigantea), vine, across northern Australia extending south into New South Wales.

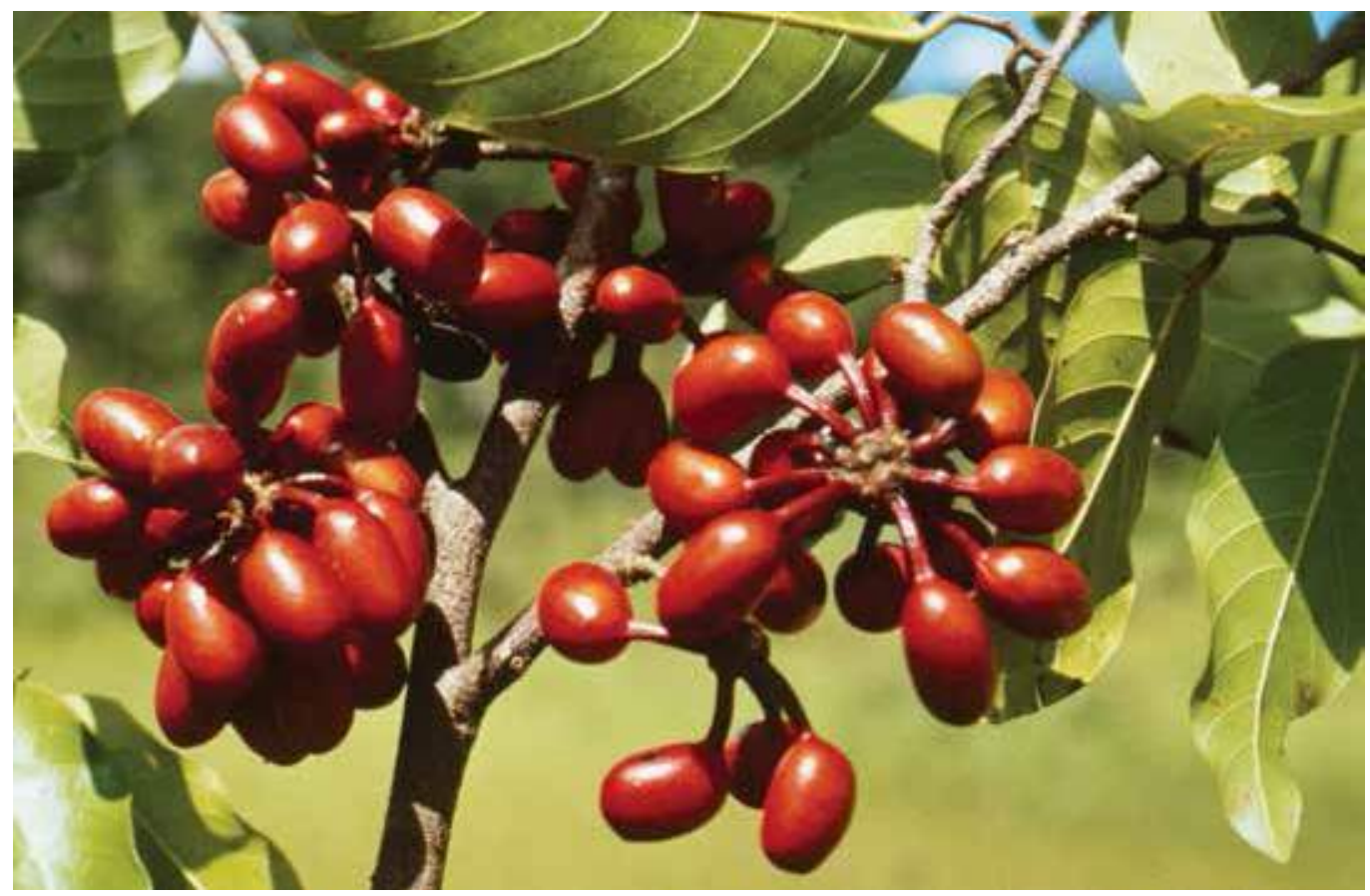

FIG. 45. Canary Beech (Polyalthia australis), endemic to Australia widespread across the north.

This document is intended for digital-device reading only.

Inquiries regarding distributable and open access versions may be directed to jbrit@brit.org. 


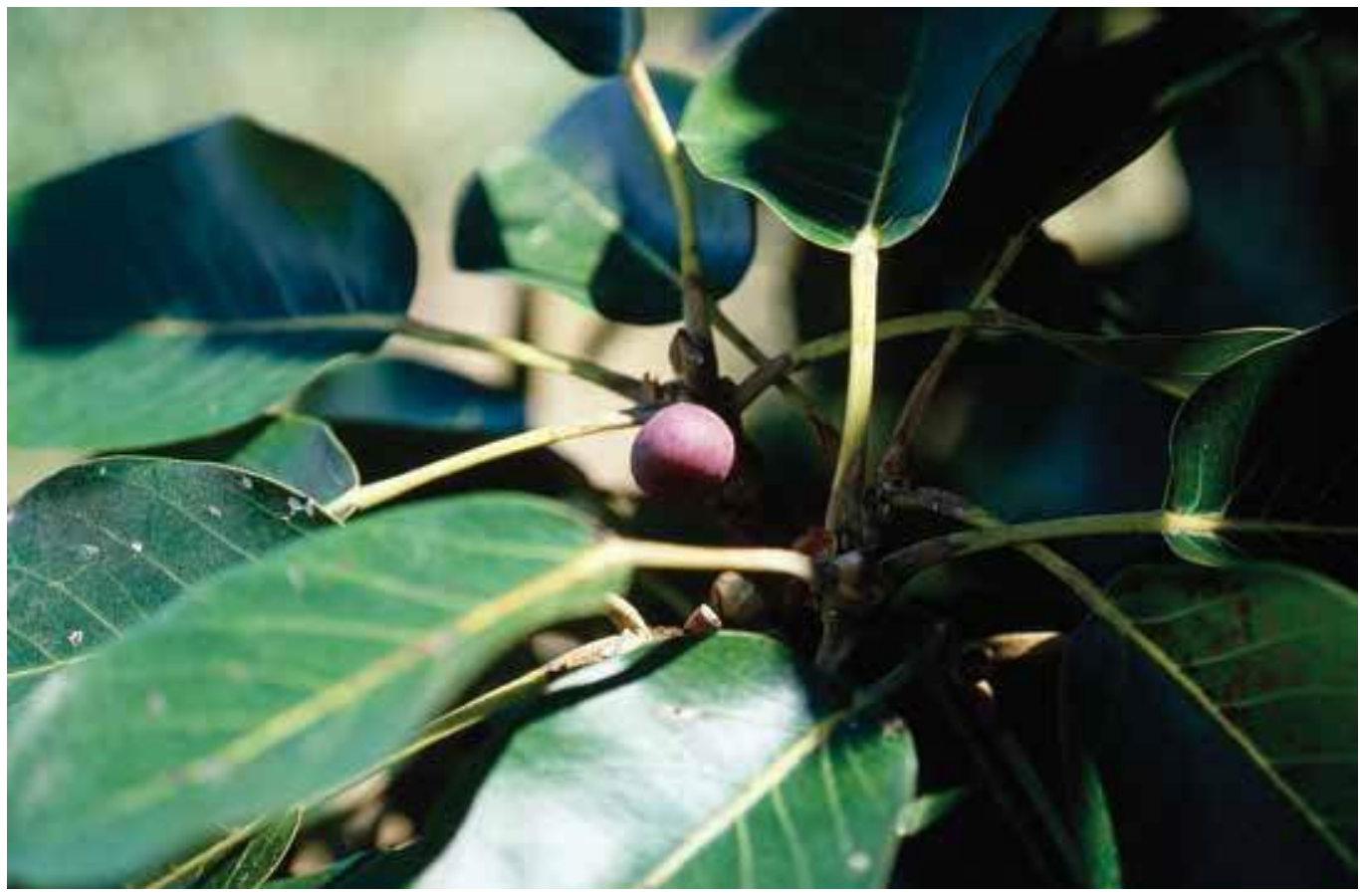

FIG. 46. Banyan (Ficus virens), fruiting, widespread across northern Australia, also Asia and Malesia.

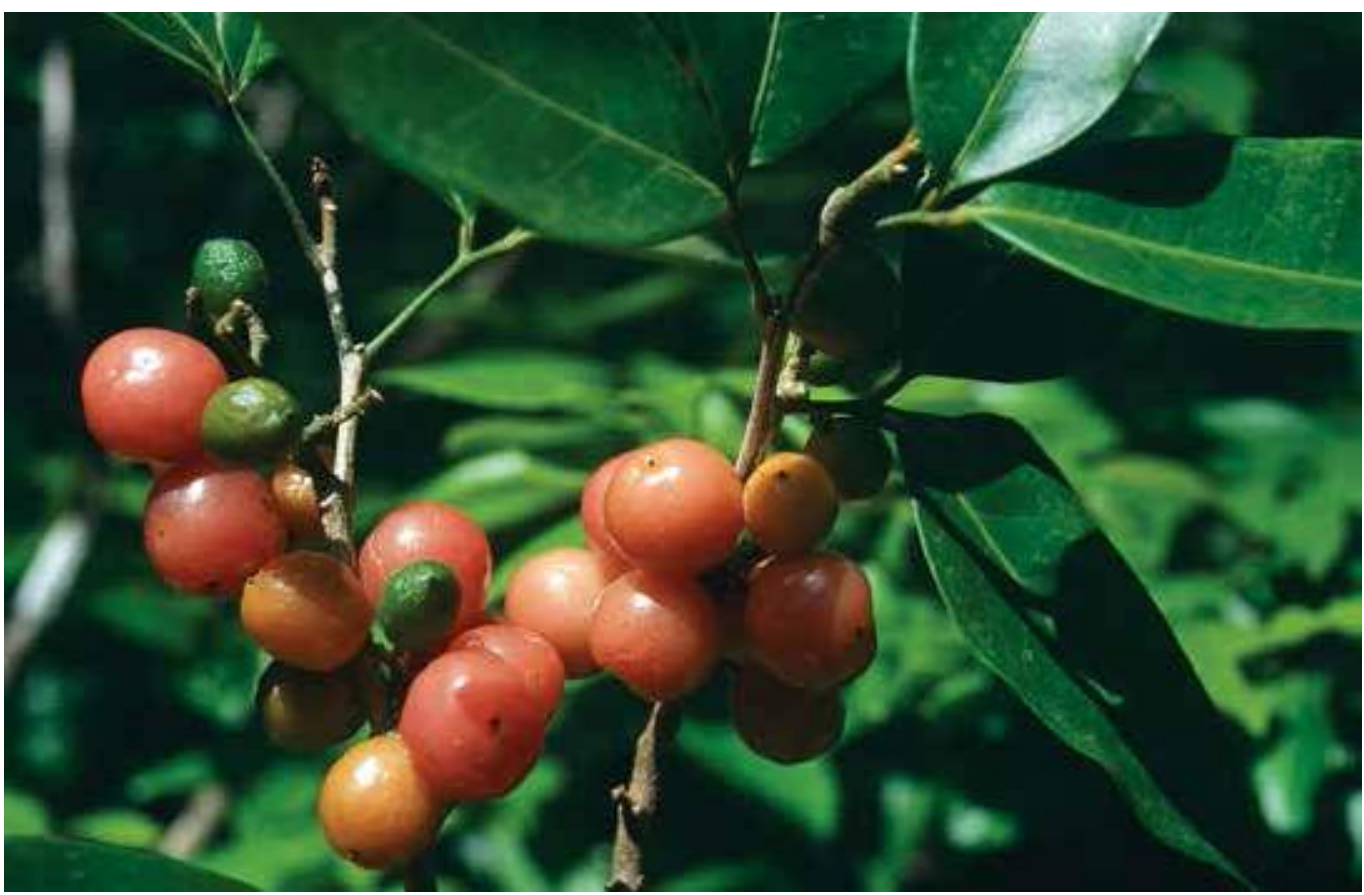

FIG. 47. Moolinyj (Glycosmis trifoliata), widespread across northern Australia, also Asia and Malesia.

This document is intended for digital-device reading only. 


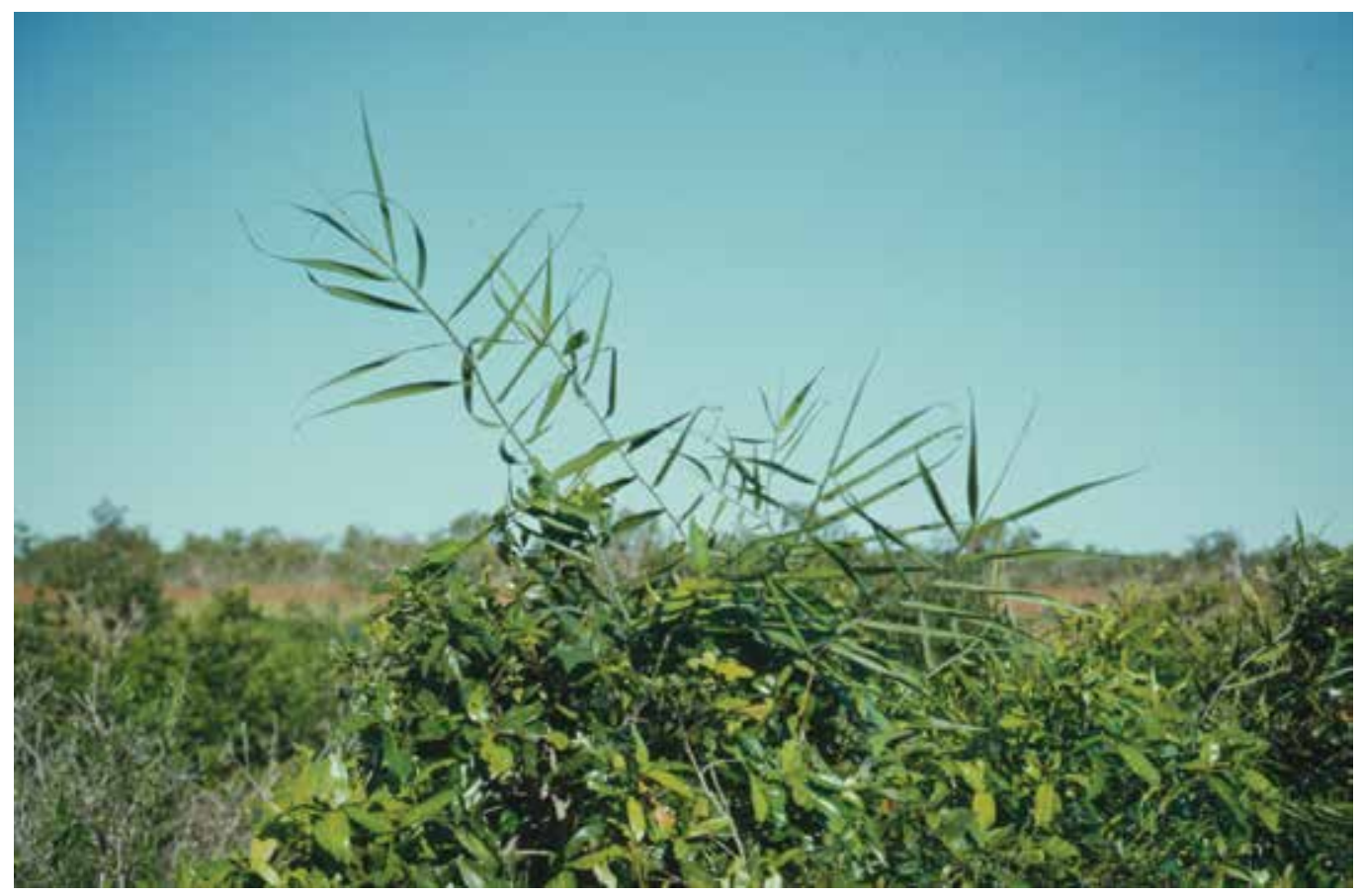

FIG. 48. Balbal, Supplejack or Lawyer Vine (Flagellaria indica), widespread across N. Australia, also Asia, Malesia, and Pacific Islands.

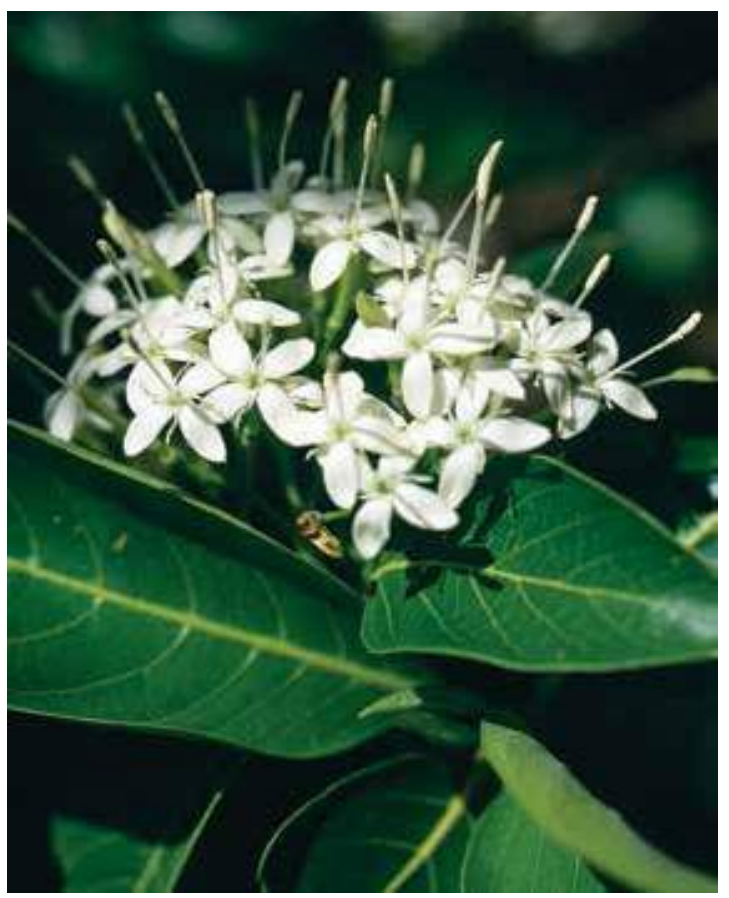

FIG. 49. Midingaran (Pavetta kimberleyana), endemic to Kimberley.

This document is intended for digital-device reading only. Inquiries regarding distributable and open access versions may be directed to jbrit@brit.org. 


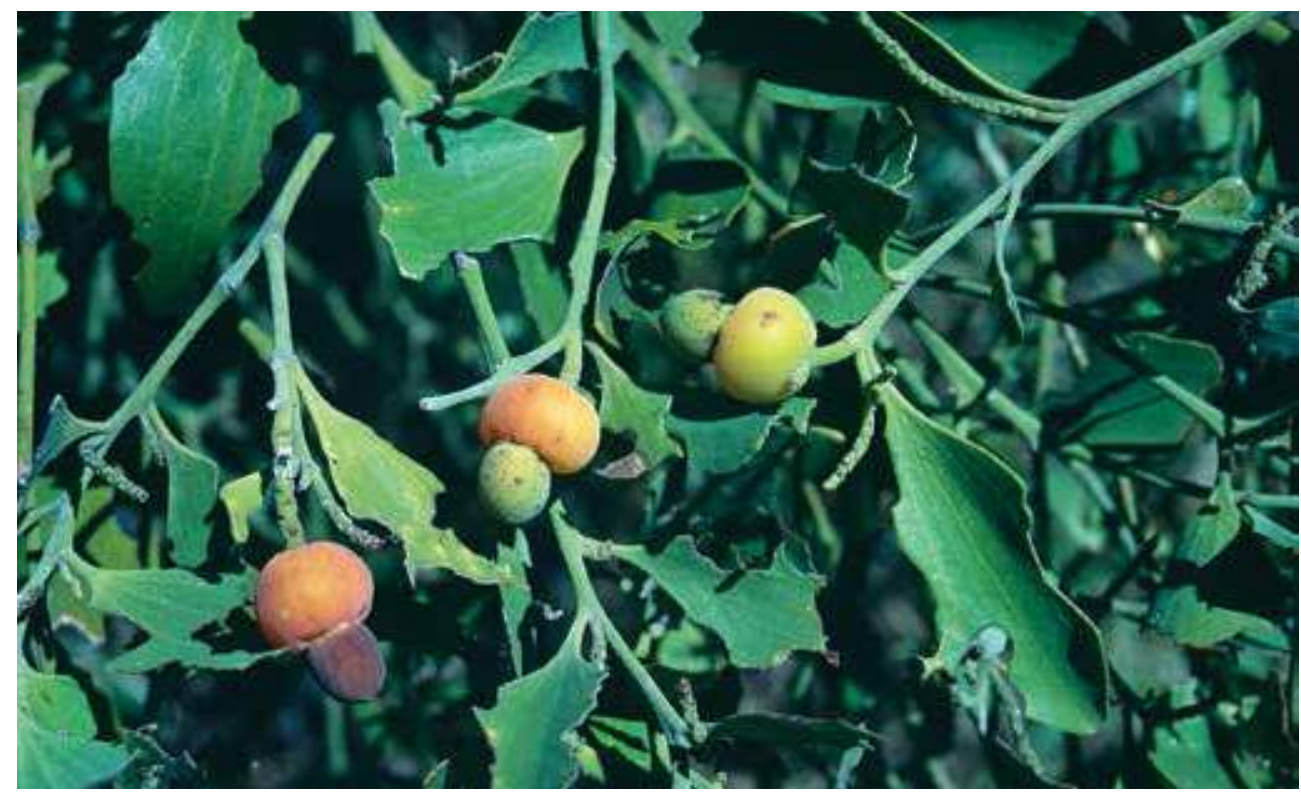

FIG. 50. Mistletoe Tree or Jarnba (Exocarpos latifolius), widespread across northern Australia, also Malesia.

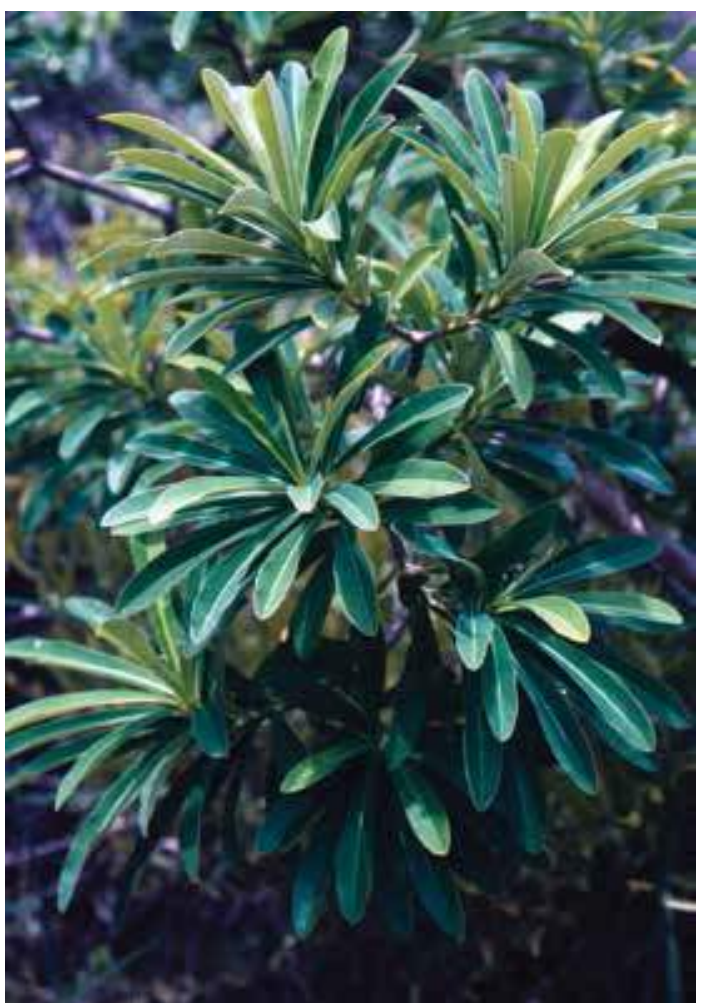

FIG. 51. Euphorbia plumerioides, occurs in WA, Cape York Peninsula, NE Queensland, also Asia and Malesia.

This document is intended for digital-device reading only.

Inquiries regarding distributable and open access versions may be directed to jbrit@brit.org. 


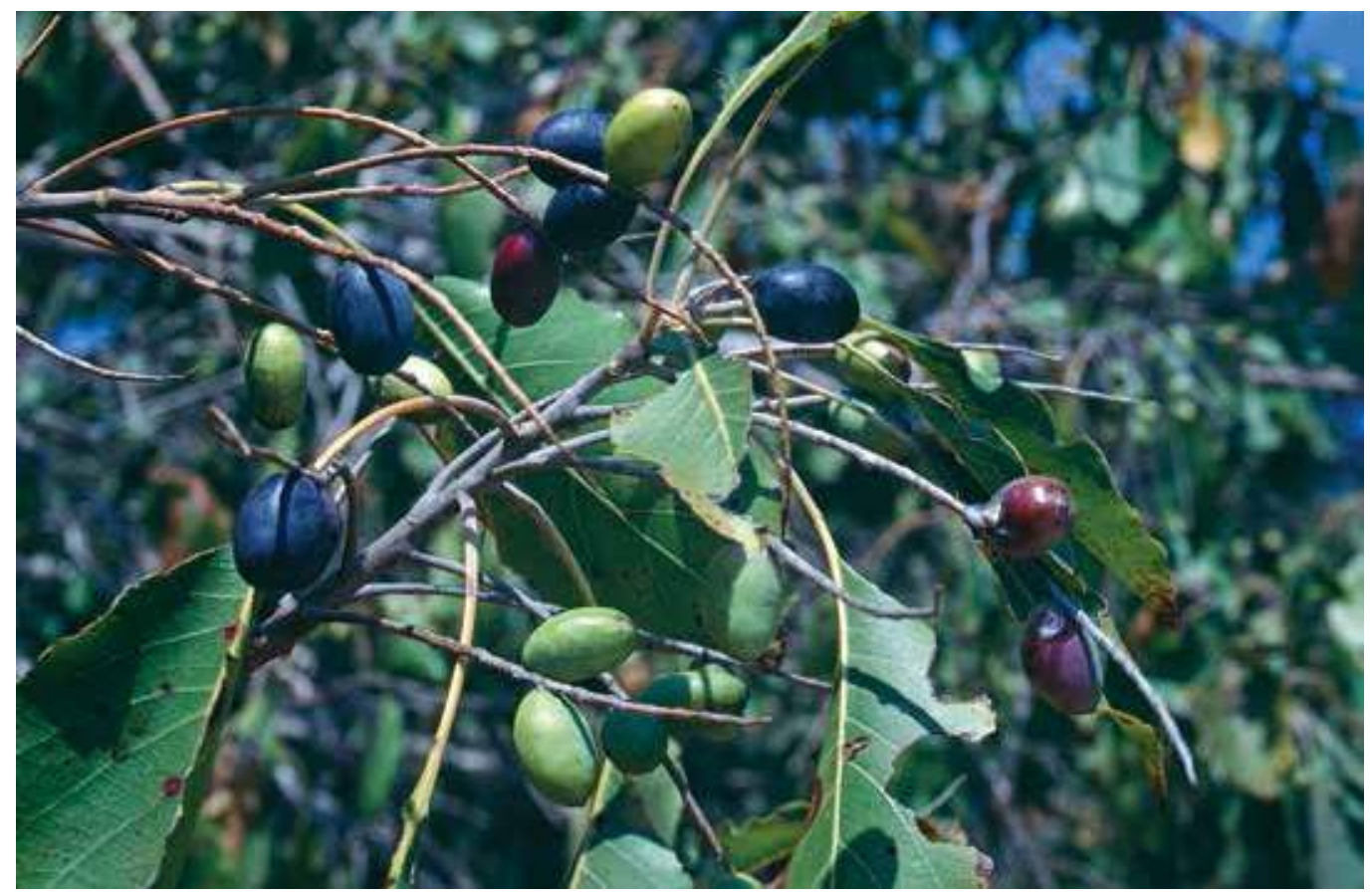

FIG. 52. Marool or Blackberry Tree (Terminalia petiolaris), endemic to coastal areas of Kimberley.

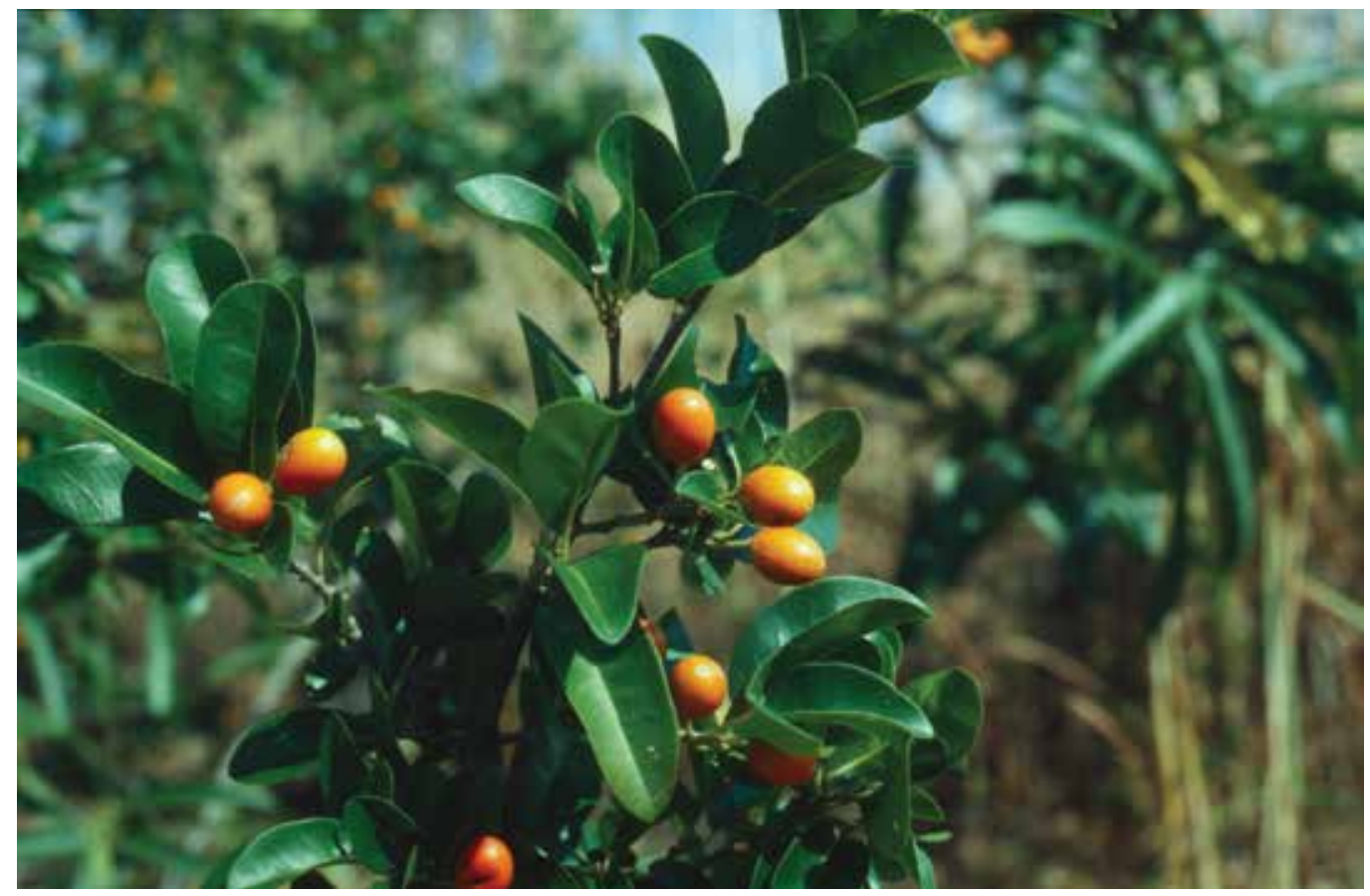

FIG. 53. Drypetes or Yellow Tulip Wood (Drypetes deplanchei), widespread across northern Australia, also New Guinea and New Caledonia. 


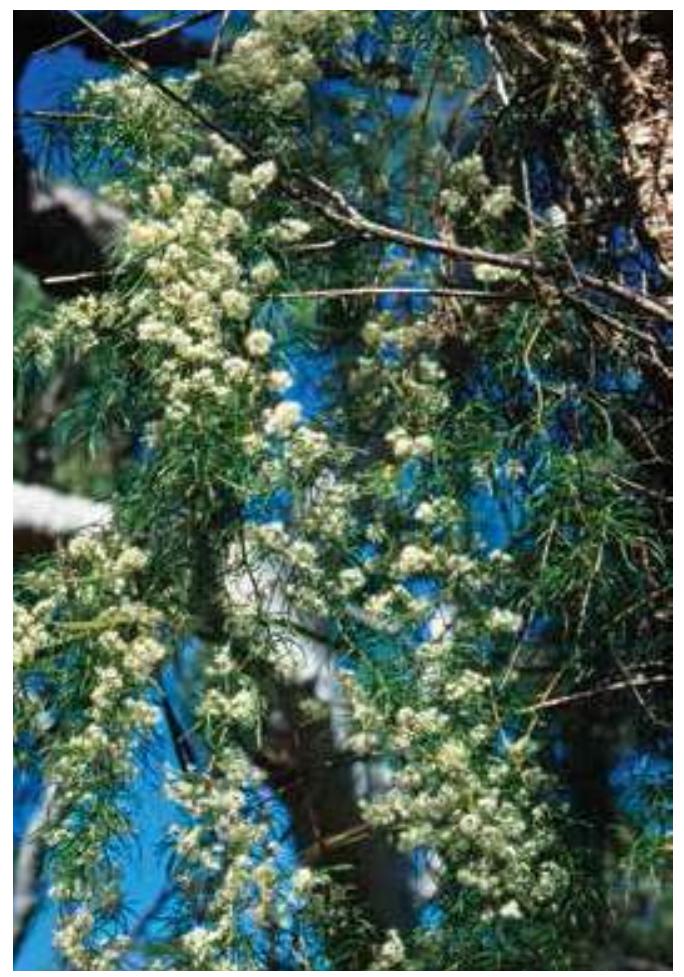

FIG. 54. Asparagus Fern (Asparagus racemosus), vine, widespread across northern Australia, also Asia and Malesia.

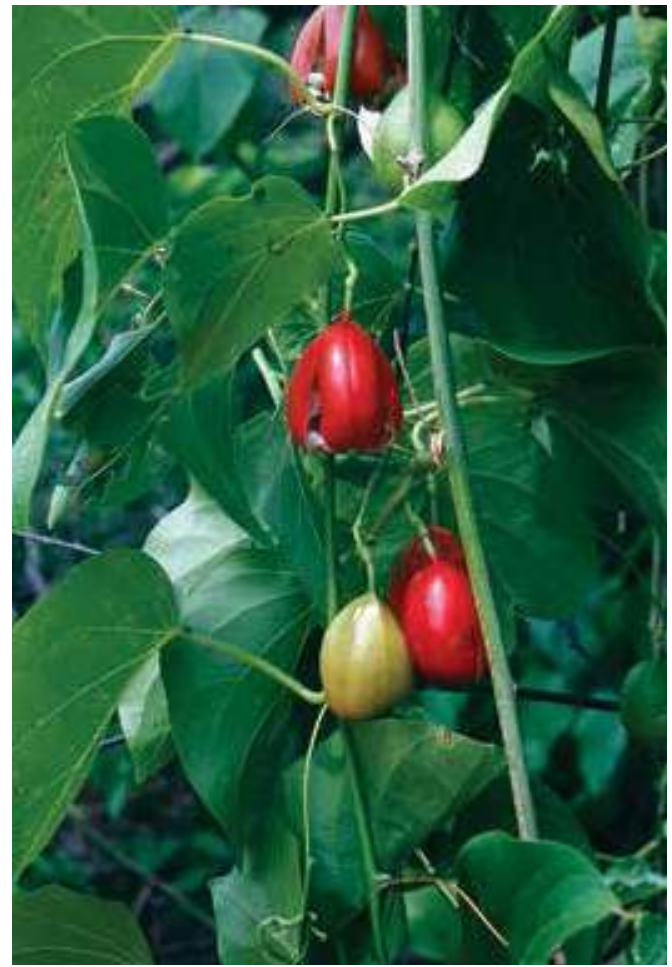

FIG. 55. Lacewing Vine (Adenia heterophylla), widespread across northern Australia, also Malesia.

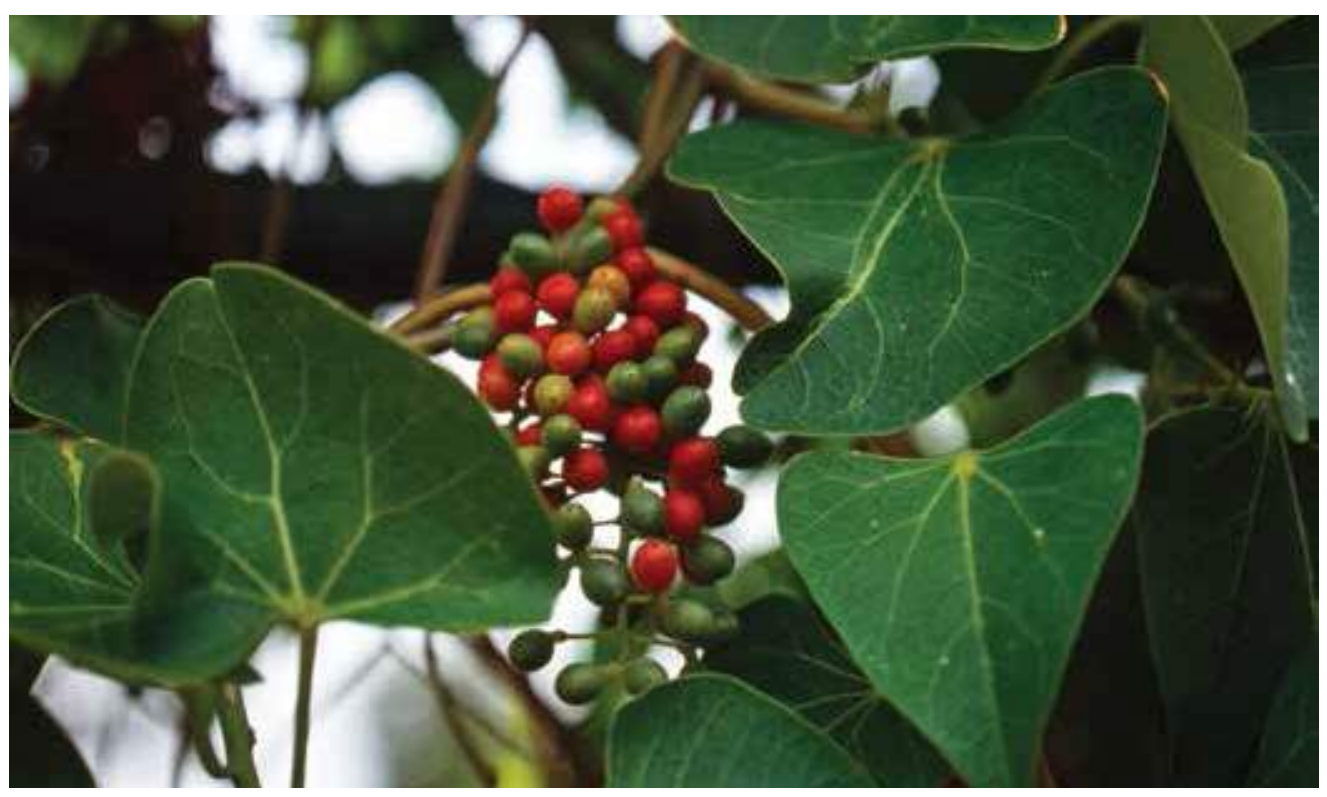

FIG. 56. Snake Vine (Tinospora smilacina) endemic to Australia, widespread across northern Australia. 


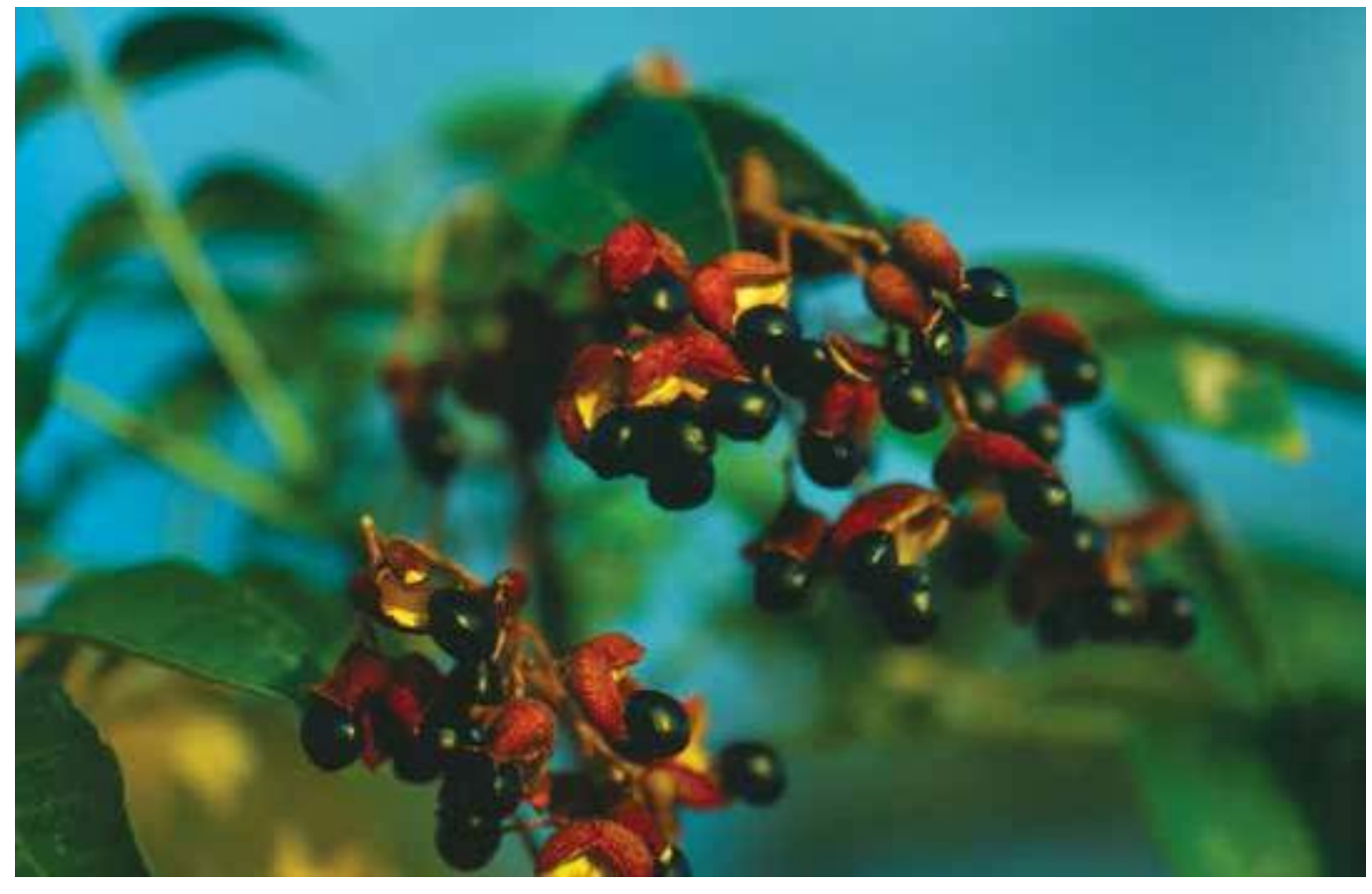

FIG. 57. Indian Prickly Ash (Zanthoxylum rhetsa), occurs in Western Australia, Cape York Peninsula and NE Queensland, also Asia and Malesia.

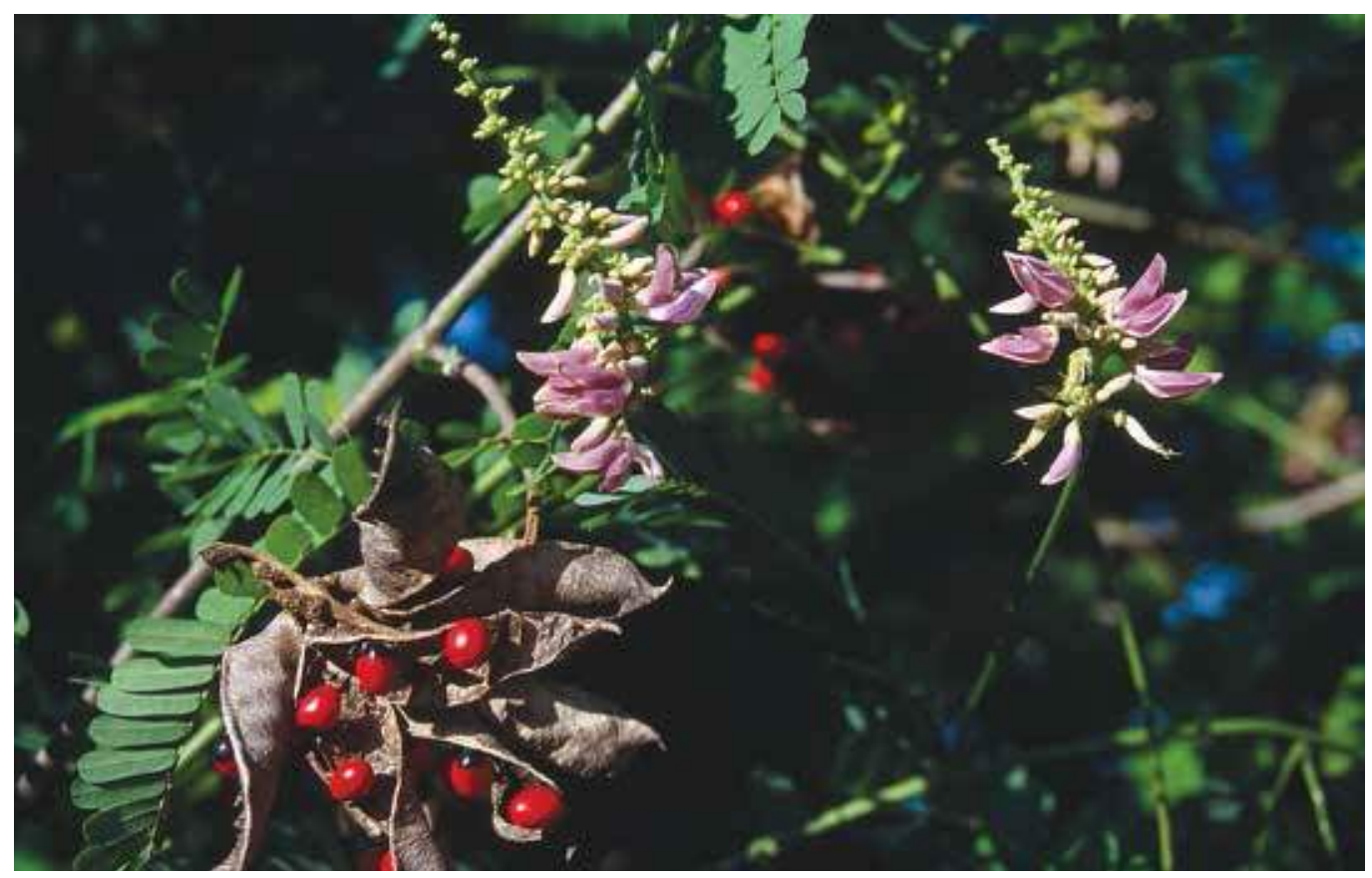

FIG. 58. Ngaming or Crab's Eye Bean (Abrus precatorius), flowers and fruits, widespread across N. Australia, also Africa, Asia, Malesia and Pacific Islands. Image-B. Carter. 


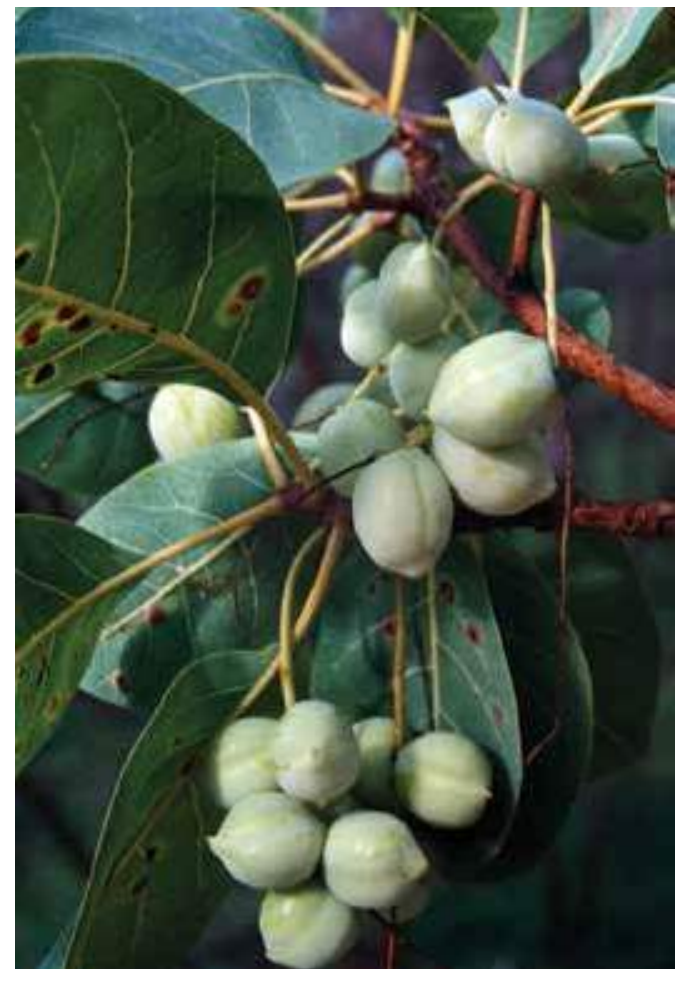

FIG. 59. Gubinge (Terminalia ferdinandiana), widespread across northern Australia.

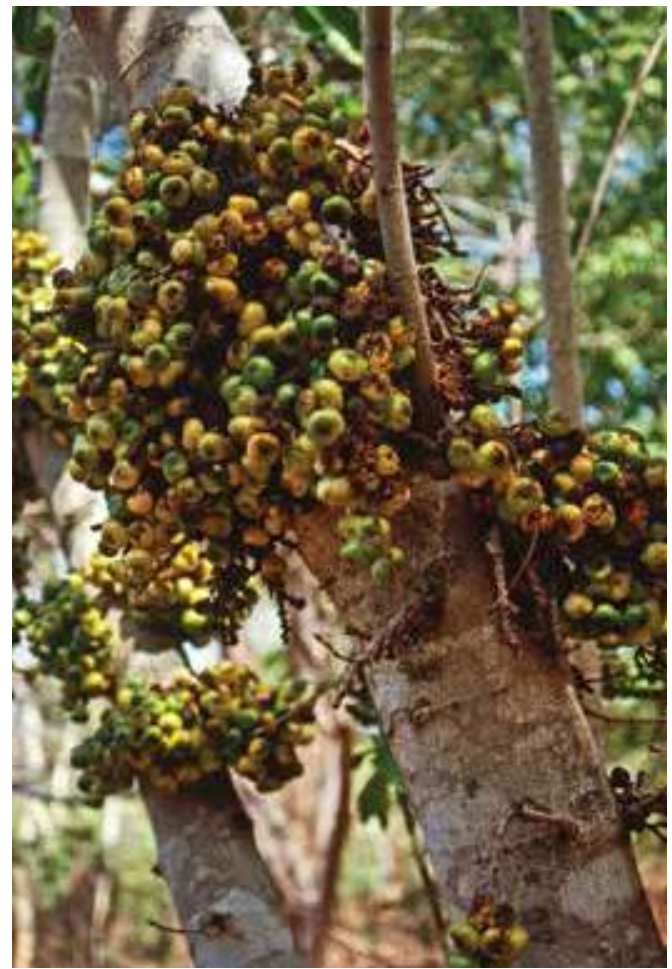

Fig. 60. Cluster Fig (Ficus racemosa), widespread across northern Australia, also Asia and Malesia.

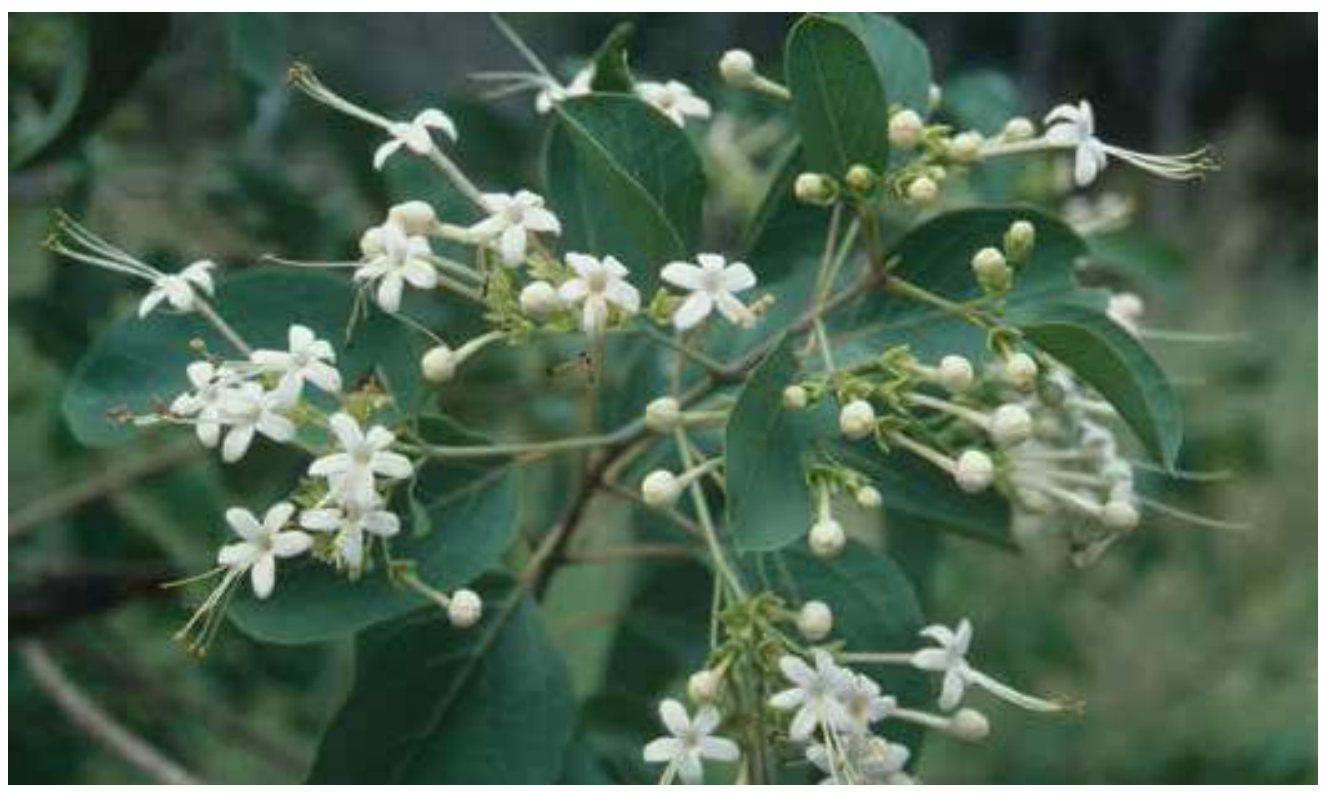

FIG. 61. Lolly Bush (Clerodendrum floribundum), widespread across northern Australia, also Timor and New Guinea. 


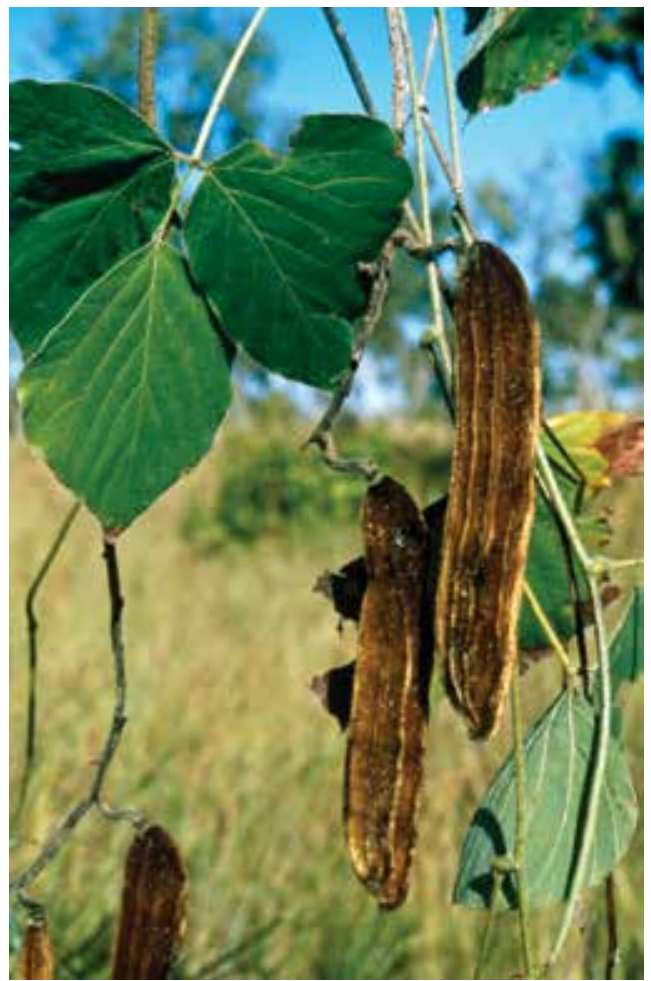

Fig. 62. Itchy Bean (Mucuna diabolica subsp. kenneallyi), vine, endemic to Kimberley monsoon rainforests.

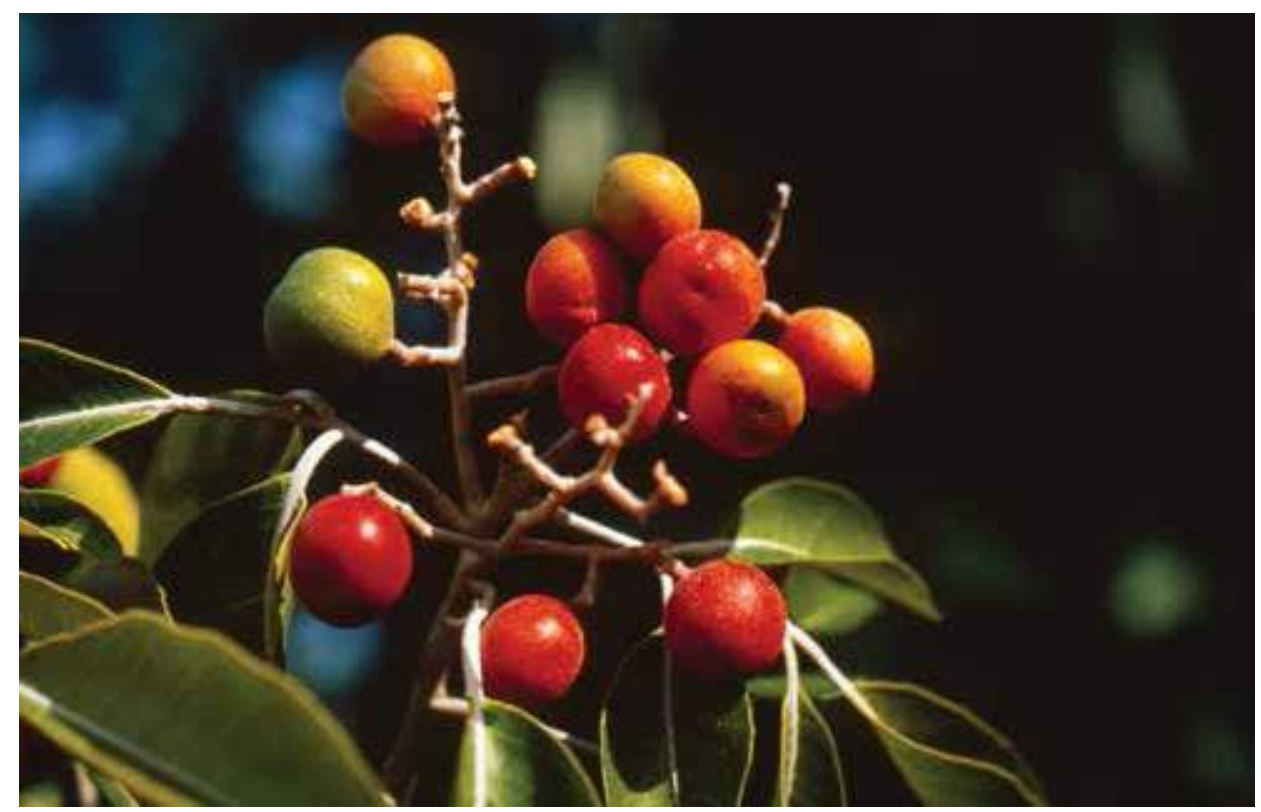

FIG. 63. Droopy Leaf (Aglaia elaeagnoidea), fruits, occurs in Kimberley, Cape York and Queensland, also India, Asia, Malesia, Taiwan and New Caledonia.

This document is intended for digital-device reading only.

Inquiries regarding distributable and open access versions may be directed to jbrit@brit.org. 


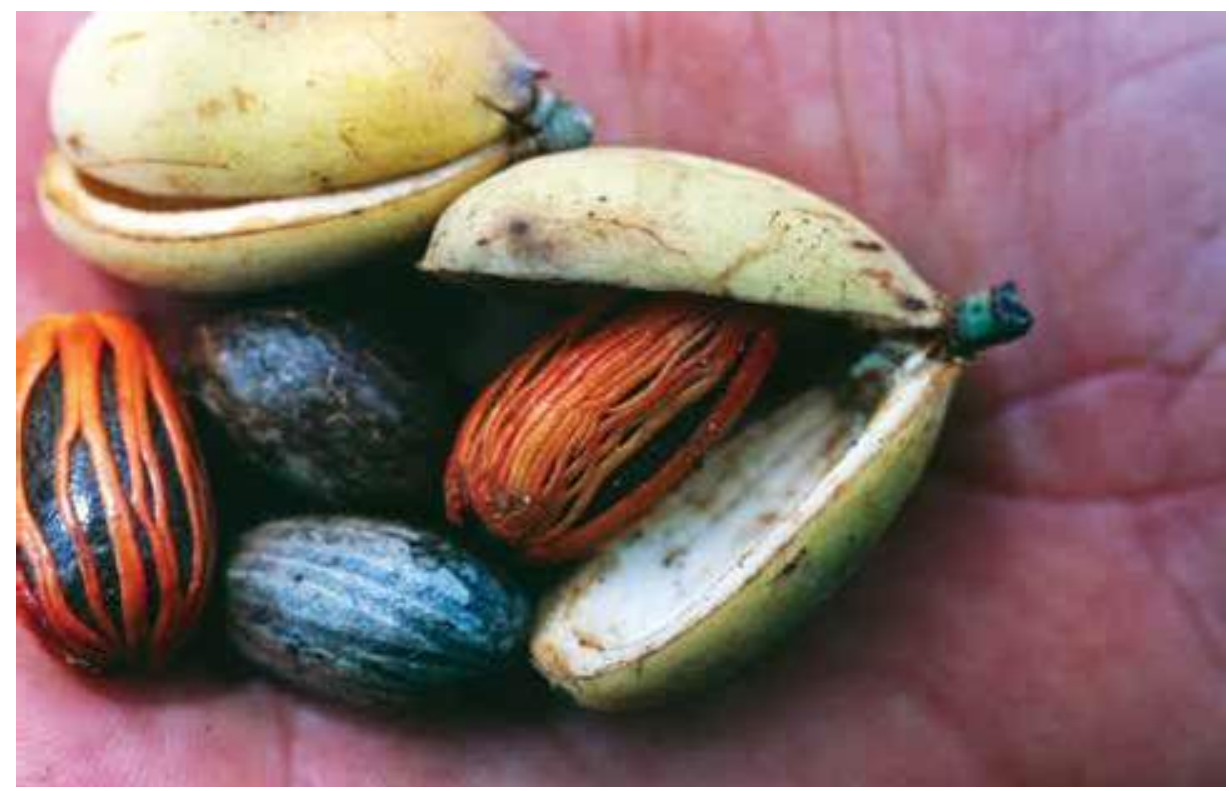

FIG. 64. Fruit of Australian Nutmeg (Myristica insipida) showing reddish 'lacy' covering or aril covering the seed. The fruit is a favoured food of the Pied Imperial Pigeon. Widespread across northern Australia, also Malesia and Solomon Islands.

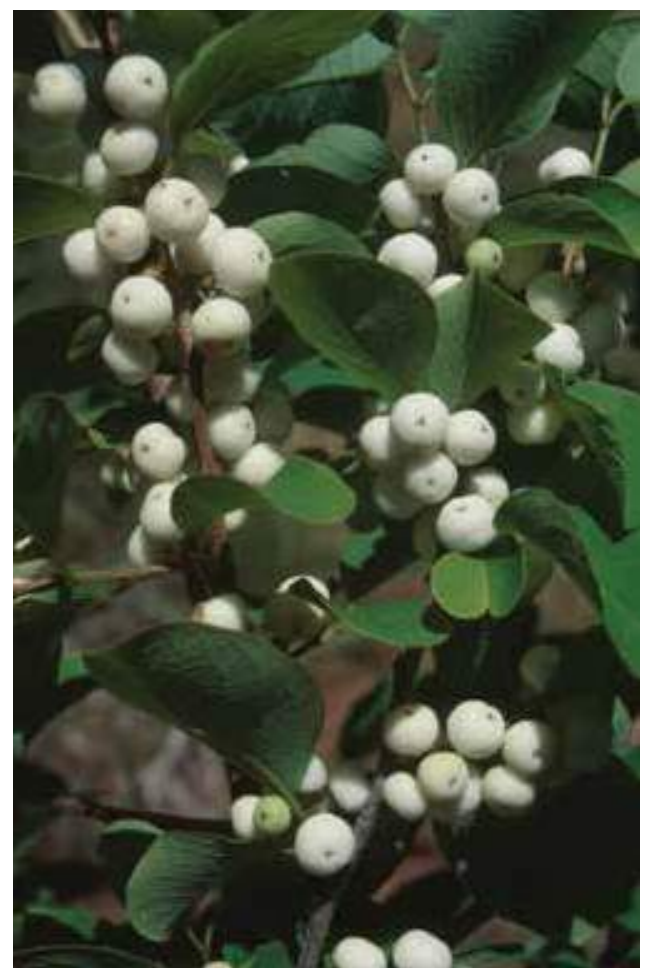

FIG. 65. Gooralgarr or Snowball Bush (Fluegea virosa), widespread across northern Australia, also New Guinea.

This document is intended for digital-device reading only.

Inquiries regarding distributable and open access versions may be directed to jbrit@brit.org. 


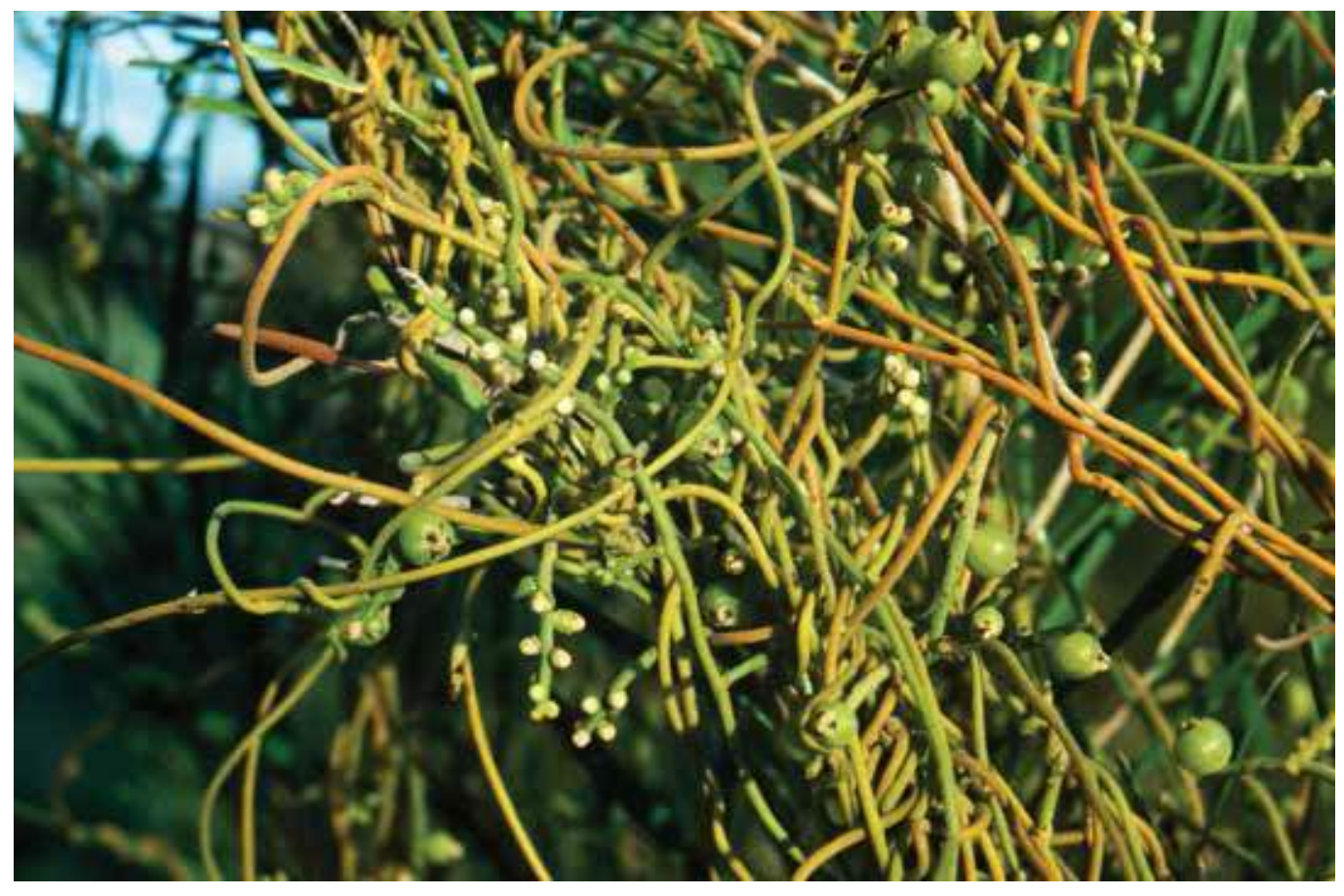

FIG. 66. Love Vine or Yugulu (Cassytha filiformis), a pantropical species widespread across northern Australia.

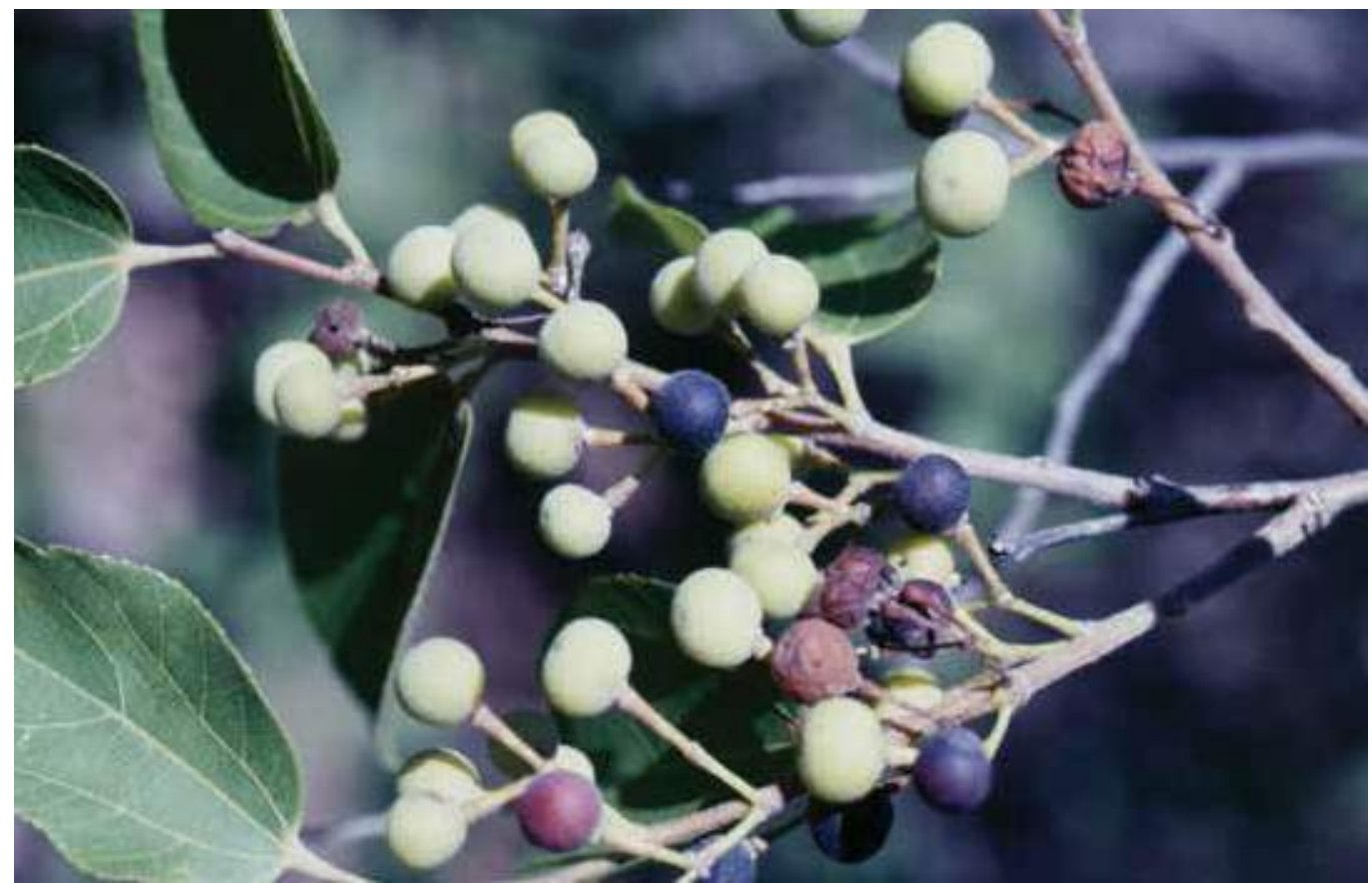

FIG. 67. Goolmi, Currant or Coffee Fruit (Grewia breviflora), fruits, widespread in N. Australia, also Northern Territory, Cape York, Timor and New Guinea. 


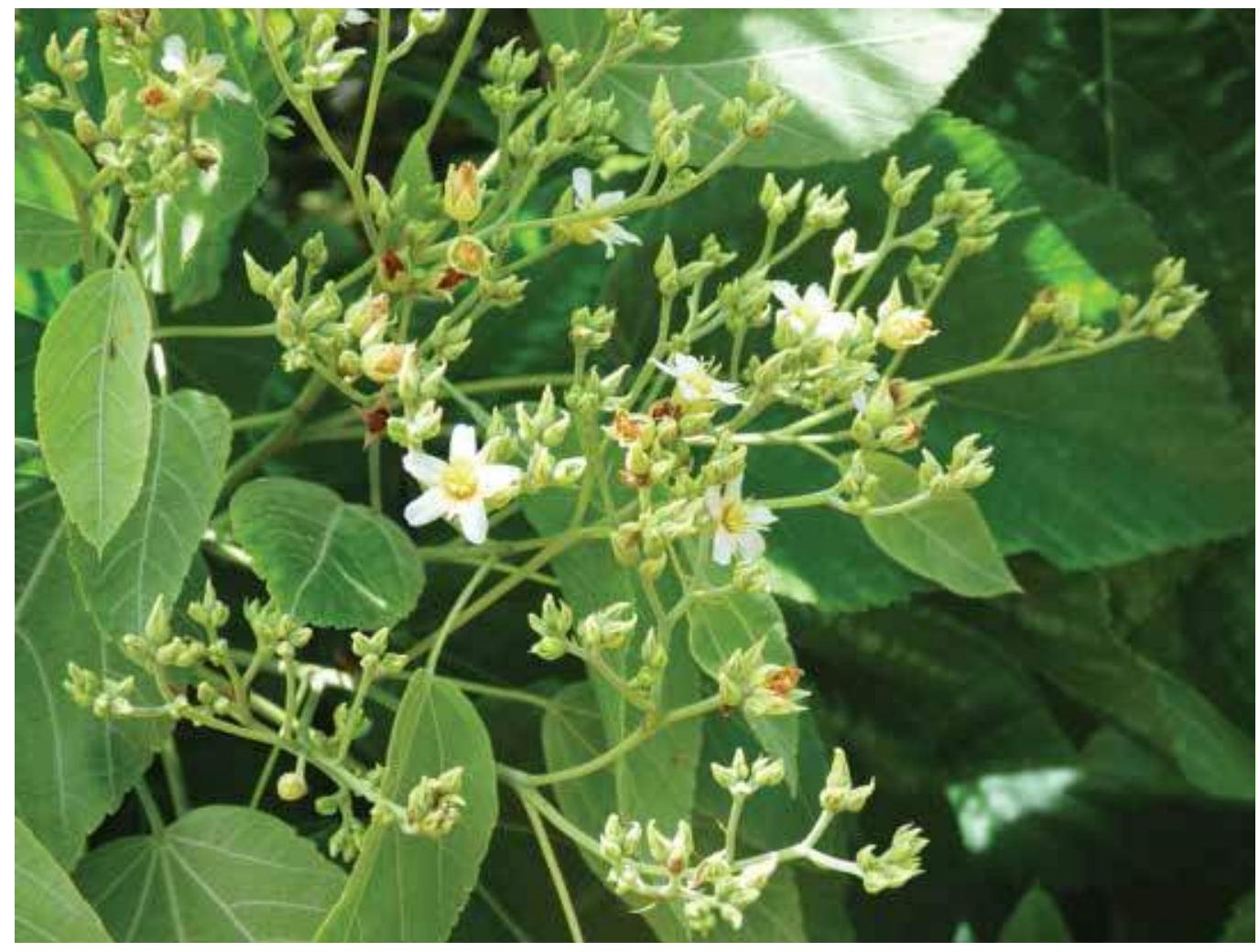

FIG. 68. Melochia umbellata, a tree restricted in Australia to Kimberley monsoon rainforests and extending into SE Asia.

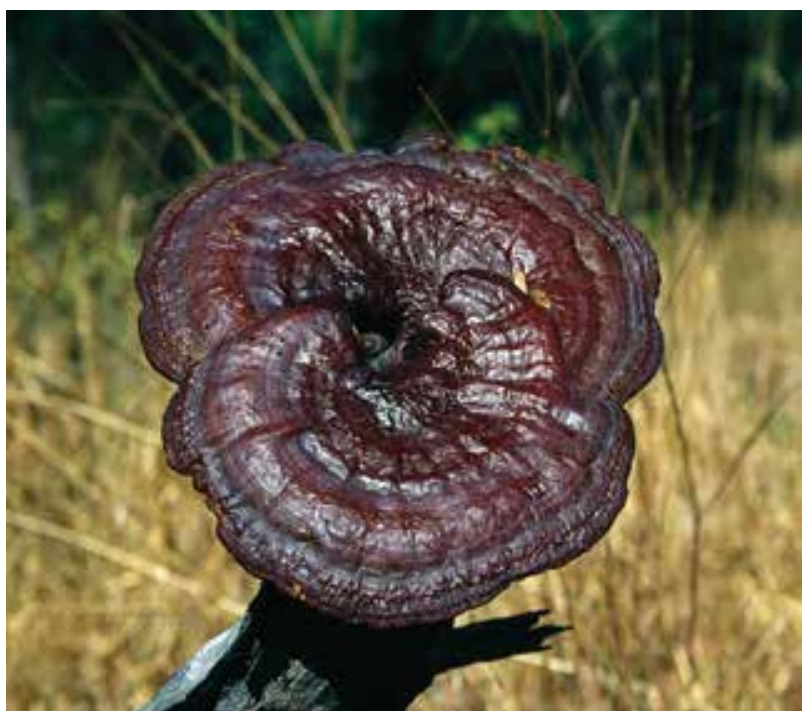

FIG. 69. The wood decaying bracket fungi (Ganoderma sp.), a genus of polypore fungi. For centuries, laccate (varnished or polished) Ganoderma species have been used in traditional medicine in many parts of Asia. 


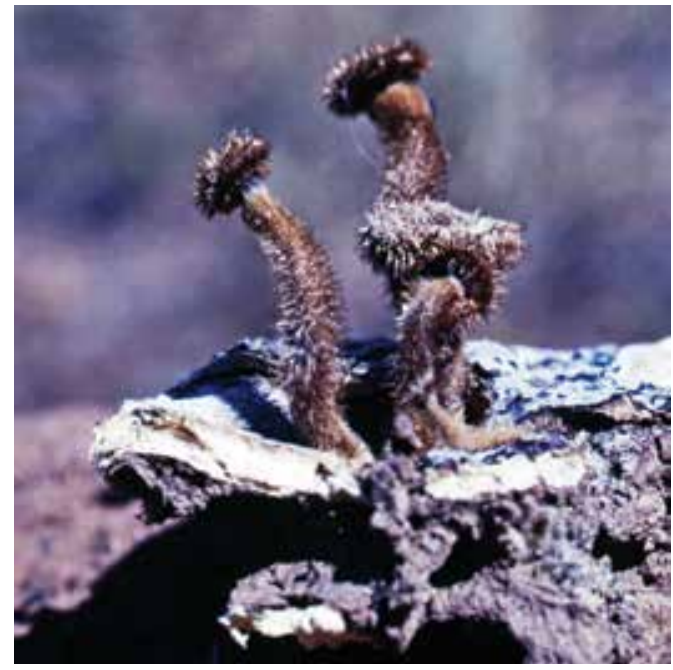

Fig. 70. The Hairy Trumpet (Panus sp.) a common wood decaying fungus.

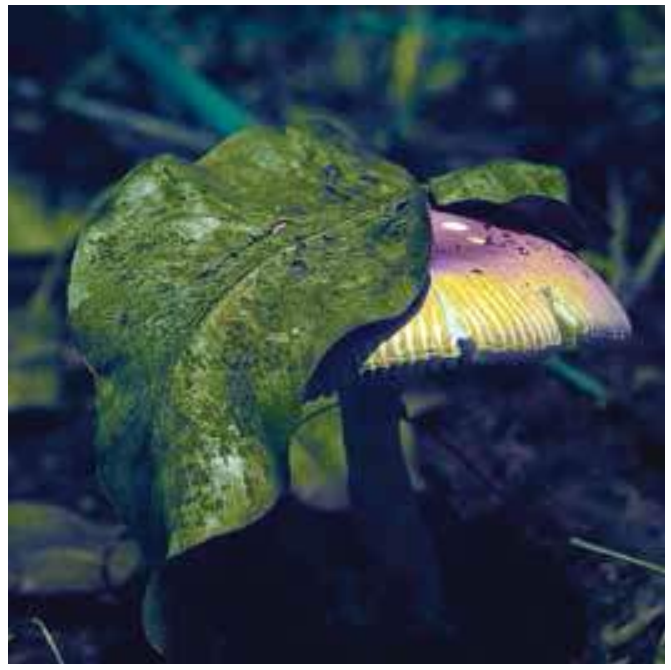

FIG. 71. Amanita aff. hemibapha, a widespread tropical fungus mycorrhizal with monsoon rainforest trees.

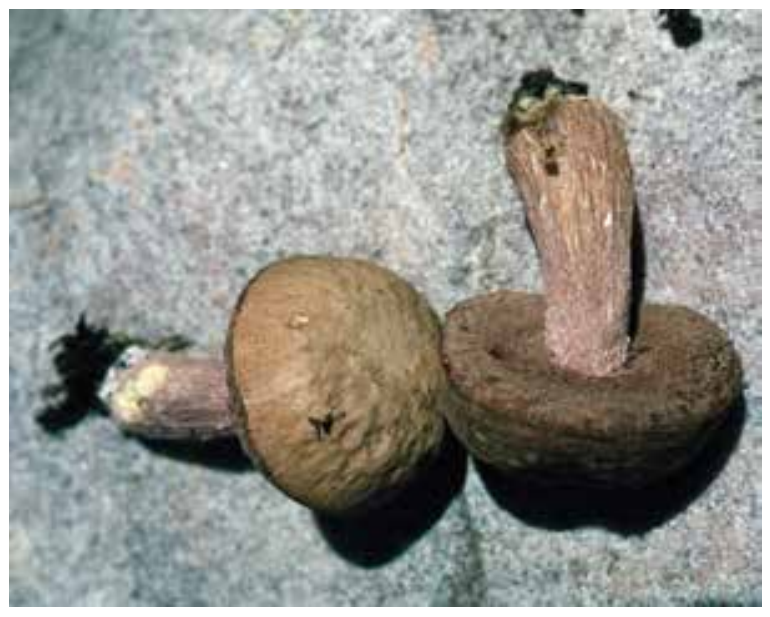

FIG. 72. Boletus (?Tylopilus sp.), a bolete fungus mycorrhizal with monsoon rainforest trees.

have disjunct distributions. The Mangarr or Wild Plum (Sersalisia sericea) appears to be endemic to Australian rainforests. Colubrina asiatica, a shrub that is common in rainforest across northern Australia (extending into New Guinea), is only known from three Kimberley rainforest patches and Margarita dubium-traceyi, common in rainforests in the Northern Territory and Queensland, has only been collected from one rainforest patch on the Bougainville Peninsula in the Kimberley. The trees Lepisanthes rubiginosa and Mellochia umbellata are species that occur in southeast Asia and Malesia, but in Australia have only been recorded from monsoon rainforest in the Kimberley. The trees Alectryon connatus, Euphorbia plumerioides, Garuga floribunda, Lagerstroemia archeriana, and the Climbing Wattle (Senegalia albizioides) are five examples of disjunct species that are common in Kimberley and north eastern Australian rainforests but do not occur in the Northern Territory (Clarkson \& Kenneally 1988; Kenneally et al. 1991). The morning glory vine Ipomoea trichosperma is restricted 
to Kimberley rainforests and Timor. The Snake Vine (Tinospora smilacina) is endemic to Australian rainforests. The Australian Jujube (Ziziphus quadrilocularis) and Alectryon kimberleyanus are endemic Australian species found in the Kimberley and Northern Territory but not in Queensland.

There are currently six plant species recognized as being endemic to Kimberley rainforest patches, but more remain to be collected and classified (Barrett 2015; Hyland et al. 2003). Also, the taxonomy of many pantropical plant groups is still unresolved. The Monsoon Hibiscus (Hibiscus peralbus), is widespread in rainforest patches and belongs to Hibiscus section Bombicella, a pantropical and subtropical group extending from the Americas through Africa, Asia and Australia with some species extending into the temperate zones (Fryxell 1987). The small tree Myrsine kimberleyensis, and the shrub Pavetta kimberleyana are well represented in rainforest patches. The aromatic shrub Backhousia gundarara, found only in one rainforest patch at the southern end of the Jameson Massif in the northwest Kimberley, is widely disjunct from the remaining Backhousia species that occur in the eastern Australian rainforests. It appears to be a lineage isolated by increasing aridity during the Miocene (Harrington et al. 2012). The vines Mucuna diabolica subsp. kenneallyi from the Mitchell Plateau and Parsonsia kimberleyensis from Cape Leveque on the Dampier Peninsula are endemic to Kimberley monsoon rainforest.

Another rainforest plant of interest that occurs in the same area as Backhousia gundarara, is Kalanchoe spathulata, a succulent that is only known in Australia from Kimberley rainforest but has a widespread distribution extending through Malesia, Indo-China, the Indian subcontinent, Japan and China (Kenneally 1983; Ohba 2003).

Native figs (Ficus spp.) are one of the most important groups of plants in rainforests for tropical frugivores. Figs possess diverse habits, many of which are characteristic of tropical rainforest plants such as hemiepiphytes, a group that includes strangler and banyan figs (Ficus virens var. virens), large woody climbers, and cauliferous trees (inflorescences borne on the trunk). The ecological advantages of cauliflory are numerous. In many cases clusters of heavy fruits are produced which, if not attached to strong woody stems, would easily be broken off. The famous tropical naturalist Alfred Russell Wallace argued that the condition arose in the dark understory of the tropical forest as a result of selection for trunk flowers, which are more apparent to pollinators than canopy flowers (Warren et al. 1997). Figs provide an abundance of food all year and may be critically important to wildlife when other fruits are unavailable. Many fig species are pioneer colonizers and play a significant role in the establishment of rainforest patches (Shanahan et al. 2001). Native figs have been shown to be high in calcium, yielding nearly three times more calcium than non-fig fruits (Kinnaird 2000).

Under the Western Australia's newly proclaimed Biodiversity Conservation Act 2016 (BC Act), individual species of plants and animals are protected. Two "Objects" included in the State Act are the same as those in the International Convention on Biological Diversity (1993). They are: "To conserve and protect biodiversity components in the State;" and "To promote the ecologically sustainable use of biodiversity components in the State." The BC Act also includes provision for the protection of threatened species and ecological communities; collapsed ecological communities; threatening processes and critical habitat; and the control of environmental pests.

The monsoon rainforest on the coastal Holocene sand dunes of the Dampier Peninsula is listed as a vulnerable ecological community on the Western Australian Government's list of "Threatened Ecological Communities," along with the rainforest swamps at Theda, Walcott Inlet and the Roe River. In 2013, the Dampier Peninsula monsoon rainforest was recognized by the Australian Commonwealth Government as "Nationally Endangered" under Section 184 of the Environment Protection and Biodiversity Conservation Act 1999 (EPBC Act).

Directly within and behind the swales of the coastal Holocene dunes system north of Broome, on both the west and east coasts of the Dampier Peninsula, are 79 discontinuous but discrete pockets of monsoon rain forest, that occur as long narrow patches with exposed edges (Beames 2013). Between 2000-2002 Broome Botanical Society members, Sally Black, Tim Willing and Dave Dureau, identified and mapped the monsoon vine thicket patches on the Dampier Peninsula (Black 2010). The "Environs Kimberley West Kimberley Nature 
Project" is located in Broome and involves Indigenous rangers, communities and traditional owners. Their survey work has shown that these monsoon rainforest patches vary from a few trees over a small area, with most patches not exceeding $10 \mathrm{ha}$. Six patches were unusually large with one of 90 ha and five others greater than 100 ha in size. The largest patches occur at One Arm Point at the far northern end of the Peninsula above the $750 \mathrm{~mm}$ per annum rainfall zone and include the most floristically species-rich patches. The total area of the 79 patches is less than 2,600 ha and although they represent less than 0.001 percent of the total land area of the Dampier Peninsula, they contain almost a quarter of the total plant species recorded for the Peninsula (Fig. 73).

These patches are allied to monsoon rainforest but are floristically different from the rainforest patches in the wetter northwest Kimberley. They range from semi-deciduous monsoon vine thicket to closed semi-deciduous monsoon rainforest. Patches around Broome also include the endemic Cable Beach Bloodwood (Corymbia paractia). North of Weedong Well, on the west coast of the Dampier Peninsula, trees species can include Goonj (Celtis philippensis), Croton habrophyllus, Mistletoe Tree (Exocarpos latifolius), Garnboorr (Melaleuca dealbata), Marool or Blackberry Tree (Terminalia petiolaris), and Mamajen (Mimusops elengi). In these coastal thickets, vines are more evident from inside the patch rather than in the canopy and include Capparis lasiantha, Gymnanthera oblonga, the Kimberley endemic Parsonsia kimberleyensis, Stinking Passionflower (Passiflora foetida), Snake Vine (Tinospora smilacina), and Secamone elliptica.

The monsoon vine thicket communities are best developed on the northern end of the Dampier Peninsula, especially along the western coastline. Emergent trees are up to 12 meters tall and are principally the Marool or Blackberry Tree (Terminalia petiolaris), Mangarr (Sersalisia sericea) and on the landward fringe Gubinge (Terminalia ferdinandiana). Other trees include the Banyan Fig (Ficus virens var. virens), Ficus geniculata var. insignis, and the Wild Apple (Syzygium eucalyptoides subsp. bleeseri). Species confined to localized populations include Cupaniopsis anacardioides, Diospyros maritima, D. rugulosa, Pittosporum moluccanum, Trophis scandens, and Vitex glabrata.

Plant species and fruiting times vary between patches of monsoon vine thicket along the coast. The reliability of food helps birds, bats and the Boorroo or Agile Wallaby (Macropus agilis) move between the monsoon vine thicket patches eating fruits and spreading seeds, keeping the patches ecologically connected (Figs. 74-77). The Dampierland Burrowing Snake (Simoselaps minimus) and the Dampierland Limbless Slider (Lerista apoda), are both Kimberley endemic species found only within and adjacent to monsoon vine thicket patches on the Dampier Peninsula.

Small patches of monsoon rainforest have also been recorded from coastal dunes on North Maret Island (and adjacent Berthier Island) off the Kimberley coast. Pittosporum moluccanum, a species known from the Dampier Peninsula and restricted to coastal dune monsoon forest, has been recorded in both locations. Small patches of monsoon rainforest also occur on Holocene marine dunes on the seaward edge of tidal mudflats, fringing the Timor Sea, east of Cape Domett on the far north coast. Coastal sand dunes are a very common habitat for the monsoon forest in tropical Australia and its near-absence from the northwest Kimberley is most likely due to the rarity of coastal dunes.

Riparian or gallery forests fringe the banks along the major creeks, rivers and sandstone gorges in the Kimberley. These closed-canopy communities provide biological corridors for wildlife and include plant species found in the rainforest patches. They are often only a few trees wide but contain plants that provide fleshy fruits. The dominant tree species include Alphitonia, Calophyllum, Canarium, Cryptocarya, numerous figs (Ficus spp.), Nauclea, Melaleuca, Myristica, Syzygium, and Terminalia. The understory is dominated by Antidesma, Drypetes, and screw pines (Pandanus spp.). There are usually fewer vine species present, with the exception of the ubiquitous Stinking Passionflower (Passiflora foetida).

The Mitchell Plateau area consists of the most diverse landforms and habitats in northwestern Australia and it also has the highest diversity of vertebrate fauna recorded for any comparable area in Western Australia. Open forests, particularly on the laterite plateau surfaces, have the richest and most diverse mammal assemblage. In contrast, the monsoon forest patches and sandstone contain relatively large stable populations but of fewer species, while several other habitats have seasonally variable populations and species (Bradley et al. 


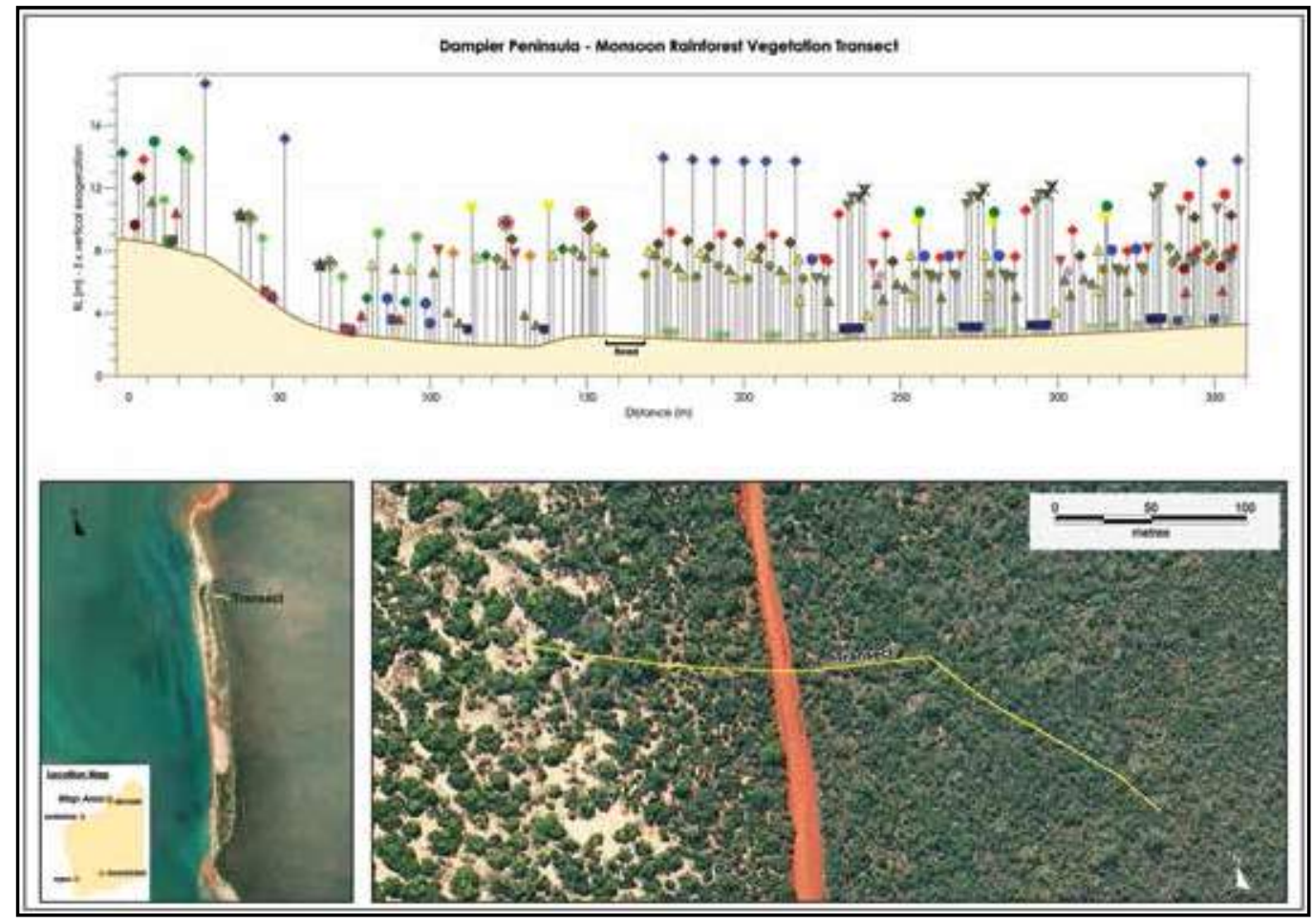

FIG. 73. Transect north of Broome extending through a coastal monsoon rainforest vine thicket (left-hand side of track) extending into pindan Acacia shrubland (right- hand side of track).

\begin{tabular}{|c|c|c|c|}
\hline \multicolumn{2}{|c|}{ Grasses } & \multicolumn{2}{|c|}{ Trees } \\
\hline bw & Cenchria cilom & $\bullet$ & Boptink ountinghers \\
\hline$\Delta$ & Combopogen ip. & $\Leftrightarrow$ & Celliphifgoencis \\
\hline 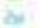 & finteopogen petitus & 8 & Cosonseomin cotwilotur \\
\hline bs & Enteopogonsp. & $\bullet$ & Conpribia beda \\
\hline as & Entercopogon dalchostactivis & 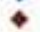 & Cormata dompiei \\
\hline as & Gochne sp nov: & 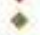 & Crotos haprephysus \\
\hline \multicolumn{2}{|c|}{ Medium to Large Shrubs } & $\bullet$ & alosores numing \\
\hline $\mathbf{7}$ & acocia solei & $\Leftrightarrow$ & 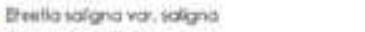 \\
\hline $\boldsymbol{\gamma}$ & Acosia eriopoda & $\Leftrightarrow$ & Exocorpos kototus: \\
\hline $\boldsymbol{v}$ & Acocio monsicala & $\Leftrightarrow$ & Griwio orevasers \\
\hline 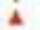 & Bevria cemua & $\bullet$ & 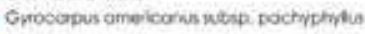 \\
\hline A & Bsdolatomentova & $=$ & Waxea rtogocorpa \\
\hline A & Coenoiphia molor & e & Mmasps elengi \\
\hline$\vec{A}$ & Colmox extipuiato & 8 & Povelta invberbyona \\
\hline 4 & Cospora bavonthe & $\theta$ & Premno ocuminata \\
\hline $\bar{A}$ & 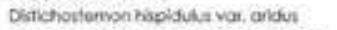 & 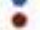 & Santalum kanceoplaturs \\
\hline $\boldsymbol{A}$ & Ruecopa viota verep, mintanthelickstei & 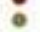 & Terminole ferdinandona \\
\hline 4 & Giscosma so. & $\bullet$ & feminalo pellokat \\
\hline $\mathbf{A}$ & Senollia vericed & & \\
\hline \multicolumn{2}{|c|}{ Small Shrubs } & \multicolumn{2}{|c|}{ Cllmbers } \\
\hline$=$ & Nurlion indicum vor, oultrolenve & & Abrus precatonis subsp pencotorin \\
\hline in & $\begin{array}{l}\text { Achinonther arpera } \\
\text { Bushavio sp. }\end{array}$ & 0 & Arsymono benthama \\
\hline$=$ & Clecene Nieosa & $\hat{A}$ & Coppors bilantho \\
\hline a & 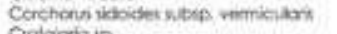 & Q & Consythosp. \\
\hline 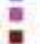 & $\begin{array}{l}\text { Golojovia is } \\
\text { Gomprema pusila }\end{array}$ & $\theta$ & jocquemontia pankaboto \\
\hline 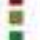 & Hyponsten norkunda vas vora & $\otimes$ & Manderie vidistons ubsp. Hotice \\
\hline in & $\begin{array}{l}\text { Ridaclera colvtea } \\
\text { indigotera innani }\end{array}$ & $\Delta$ & Pawkora fonticia ver. Fiteide? \\
\hline 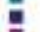 & jesminum mele & 0 & Tnoupera urtiocine \\
\hline a & Jeseptinic auponicis & $\theta$ & Tyephoid cheraicena \\
\hline 要 & Sida hacketticra & & \\
\hline : & 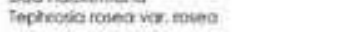 & $x$ & Deod \\
\hline
\end{tabular}




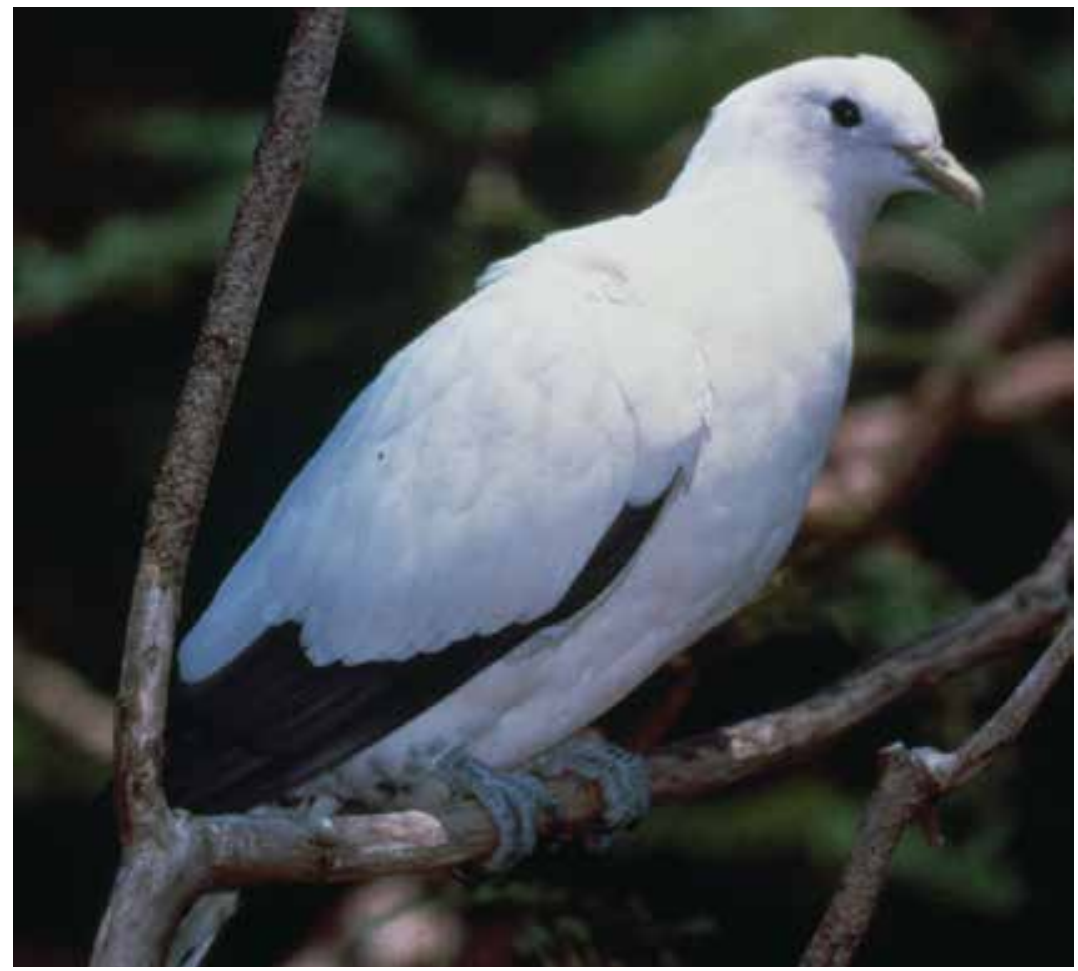

Fig. 74. Pied Imperial Pigeon (Ducula spilorrhoa). Image—R. Johnstone, WA Museum.

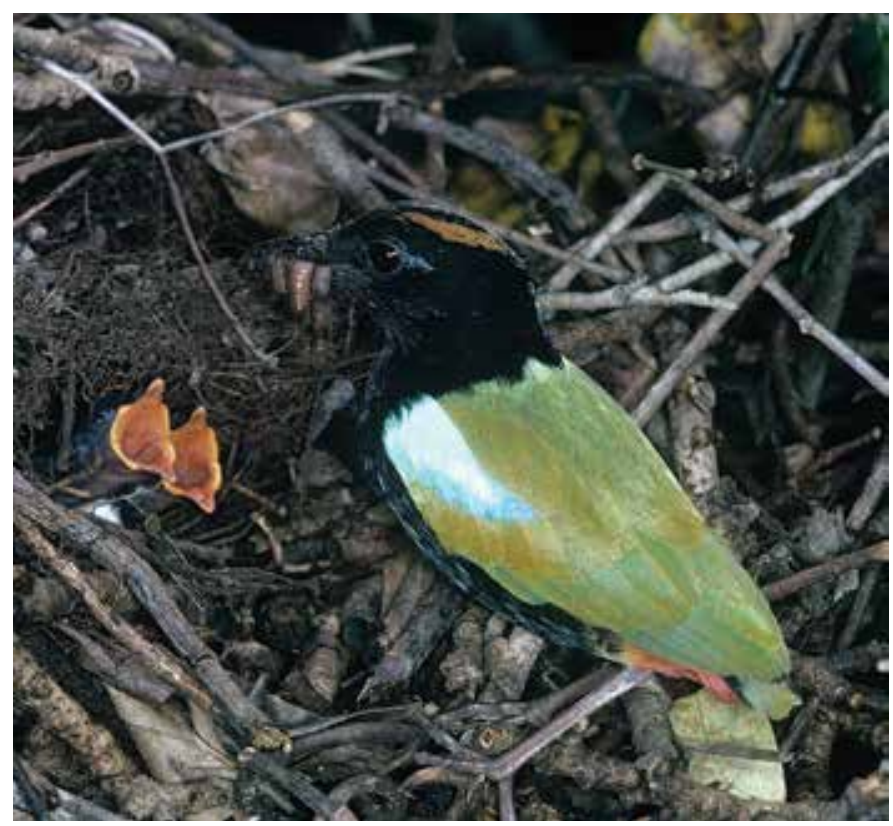

FIG. 75. Rainbow Pitta (Pitta iris johnstoneiana) feeding chicks. Image—Lochman Transparencies.

This document is intended for digital-device reading only.

Inquiries regarding distributable and open access versions may be directed to jbrit@brit.org. 


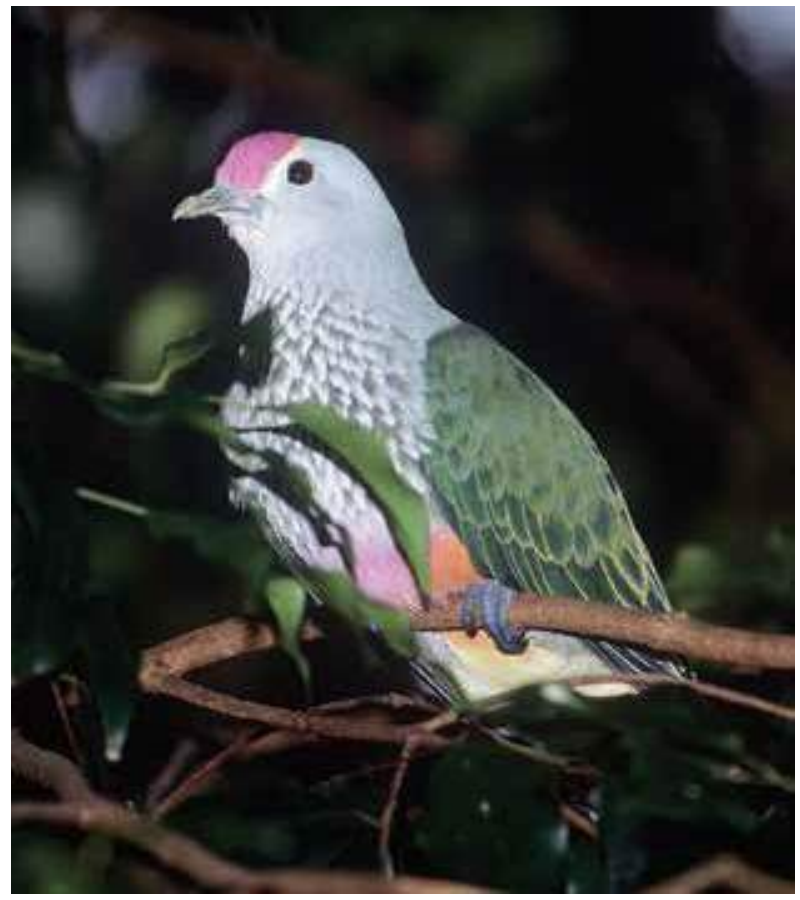

Fig. 76. Rose-crowned Fruit-dove (Ptilinopus regina). Image — Lochman Transparencies.

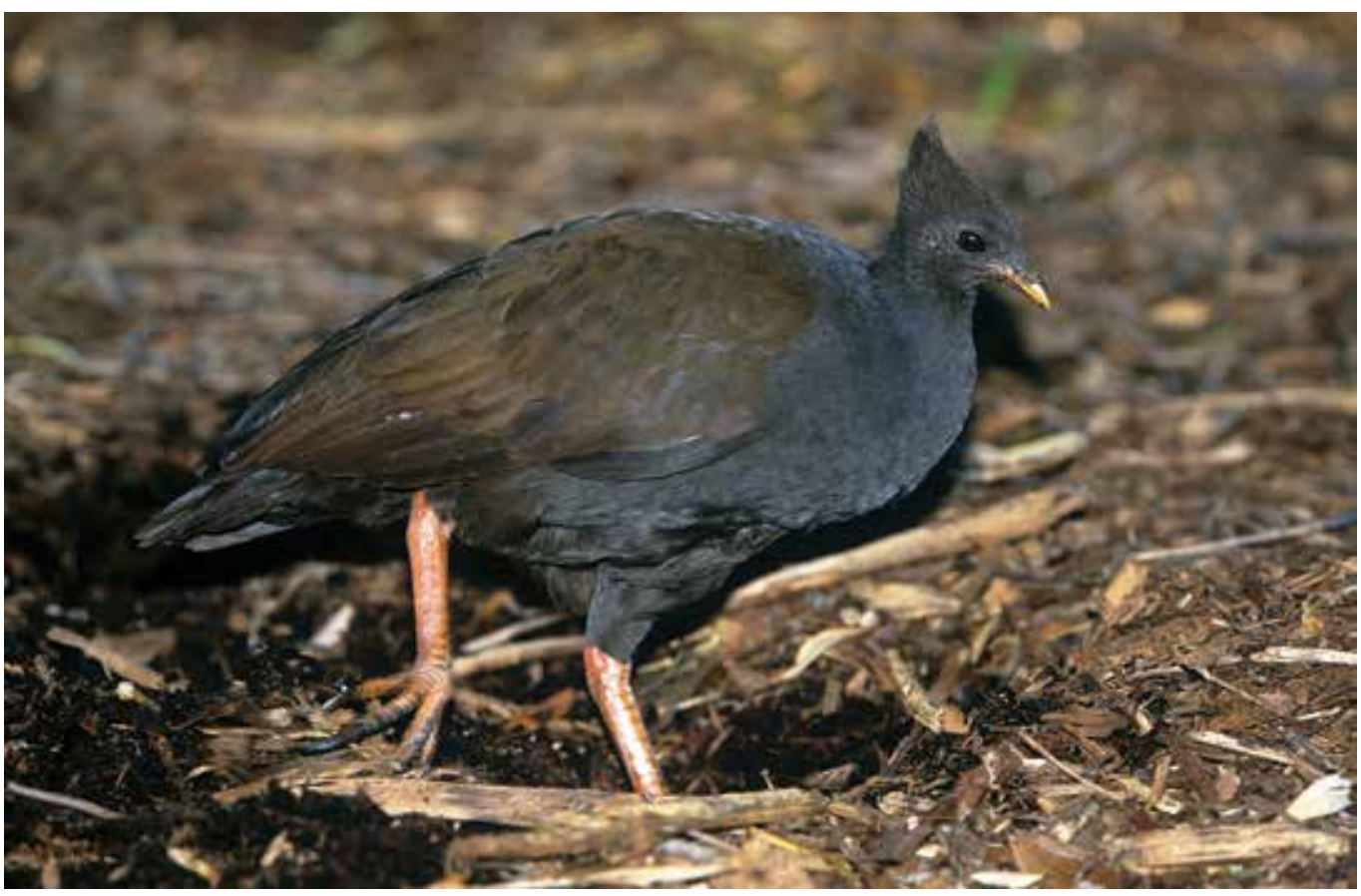

FIG. 77. Orange-footed Scrubfowl (Megapodius reinwardt). Image—Lochman Transparencies.

This document is intended for digital-device reading only.

Inquiries regarding distributable and open access versions may be directed to jbrit@brit.org. 
1987; Kenneally et al. 2003). The biological surveys undertaken on and around the Mitchell Plateau during the 1970s highlighted this diversity of species. Intensive ecological studies commenced in the early 1980s and showed, clearly, the advantages of an intensive seasonal and habitat-focused approach to sampling.

Several vertebrate groups in tropical Australia have recently undergone marked population declines (Burbidge et al. 2008). These declines are variously postulated as arising from climate change and lowered groundwater levels or from a combination of habitat alteration resulting from pastoral grazing by large herbivores (as well as feral cattle, donkeys and pigs), changed fire regimes (particularly the removal of the shrub layer of tropical savannas) and predation by feral cats (Russell-Smith et al. 1992).

The lack of rainforest specialist fauna in northwestern Australia is believed to be due to the lack of large tracts (> 1,000 ha) of monsoon rainforest habitat, the possible substantial contraction of these habitats in the past and the limited extent of well-developed gallery forest. No mammal species has been recorded as confined to Kimberley monsoon rainforests, which is not surprising considering their relatively small total area, but they are utilized by eutherian habitat generalists (murids and bats) that most commonly occur in surrounding savanna habitats. The mammal assemblages in monsoon rainforests across northern Australia (Cape York Peninsula, Northern Territory and the Kimberley) are essentially regional subsets of the local savanna and mangrove mammal assemblages, and consequently share only a limited number of species in common, most of which are bats (Bowman \& Woinarski 1994).

However, at Mitchell Plateau the endemic Kimberley Rock-rat (Zyzomys woodwardi) as well as the Grassland Melomys (Melomys burtoni) were frequently trapped in monsoon rainforests. These patches with their relatively closed-canopy and sheltered situations are utilized by a wide range of mammals including the Sugar Glider (Petaurus breviceps), Northern Brown Bandicoot (Isoodon macrourus), Little Northern Native Cat (Dasyurus hallucatus), Tunney's Rat (Rattus tunneyi), Golden-backed Tree Rat (Mesembriomys macrurus), and Common Rock Rat (Zyzomys argurus). The Scaly-tailed Possum (Wyulda squamicaudata), also a Kimberley endemic, is nocturnal and feeds on leaves, flowers and fruits. It occurs in rugged sandstone, feeding in adjacent woodland or closed forest, as well as patches in sandstone gorges that support monsoon rainforest plant species. Bats such as the Black Flying-fox (Pteropus alecto), Little Red Flying-fox (Pteropus scapulatus), Northern Blossom-bat (Macroglossus minimus), and the Yellow-lipped Cave Bat (Vespadelus douglasorum) have all been recorded feeding in rainforest patches. It is worth noting that the Grassland Melomys and the Northern Brushtail Possum (Trichosurus arnhemensis), both arboreal feeders, were observed at night in the seaward fringe of mangroves at Walsh Point on the Mitchell Plateau (Bradley et al. 1987) (Figs. 78-85).

The Kimberley has a rich herpetofauna with approximately 42 reptiles and about half that number of frogs endemic to the region. However, no herpetofauna species are entirely restricted to monsoon rainforest habitat. Only one species Carlia johnstonei seems to occur at higher density in rainforest patches than in other habitats (Kendrick \& Rolfe 1991). Other species recorded from rainforest include the Kimberley endemics the Rough-scaled Python (Morelia carinata) and Giant Slender Blue-tongue (Cyclodomorphus maximus). The Carpet Python (Morelia spilota variegata), Olive Python (Liasis olivaceus), and Brown Tree Snake (Boiga irregularis) have a more widespread distribution in the tropics but are commonly encountered in rainforest and riparian patches (Figs. 86-90).

Green Tree Ants (Oecophylla smaragdina), sometimes called Weaver Ants, build balloon-shaped nests among the foliage of trees and shrubs. Green Tree Ant workers are aggressive and defend their nests by swarming onto any unfortunate intruder and attacking with great ferocity, several ants biting at the same time (Fig. 91). They cannot sting, but bite with their jaws and squirt a burning fluid onto the wound. Research on the ant fauna of the monsoon vine thickets of the Dampier Peninsula has shown that frequent fire promotes vegetation structural changes, including a more open canopy, favoring arid-adapted ant taxa. Long-term fire exclusion encourages more shade-tolerant forest associated species, with a different ant fauna developing as succession proceeds to rainforest (Fisher et al. 2014).

Many insects pass the relatively inhospitable season as dormant immature stages concealed in the soil, in nests, or within plant tissue (Naumann et al. 1991). It has been noted during the dry season that low 


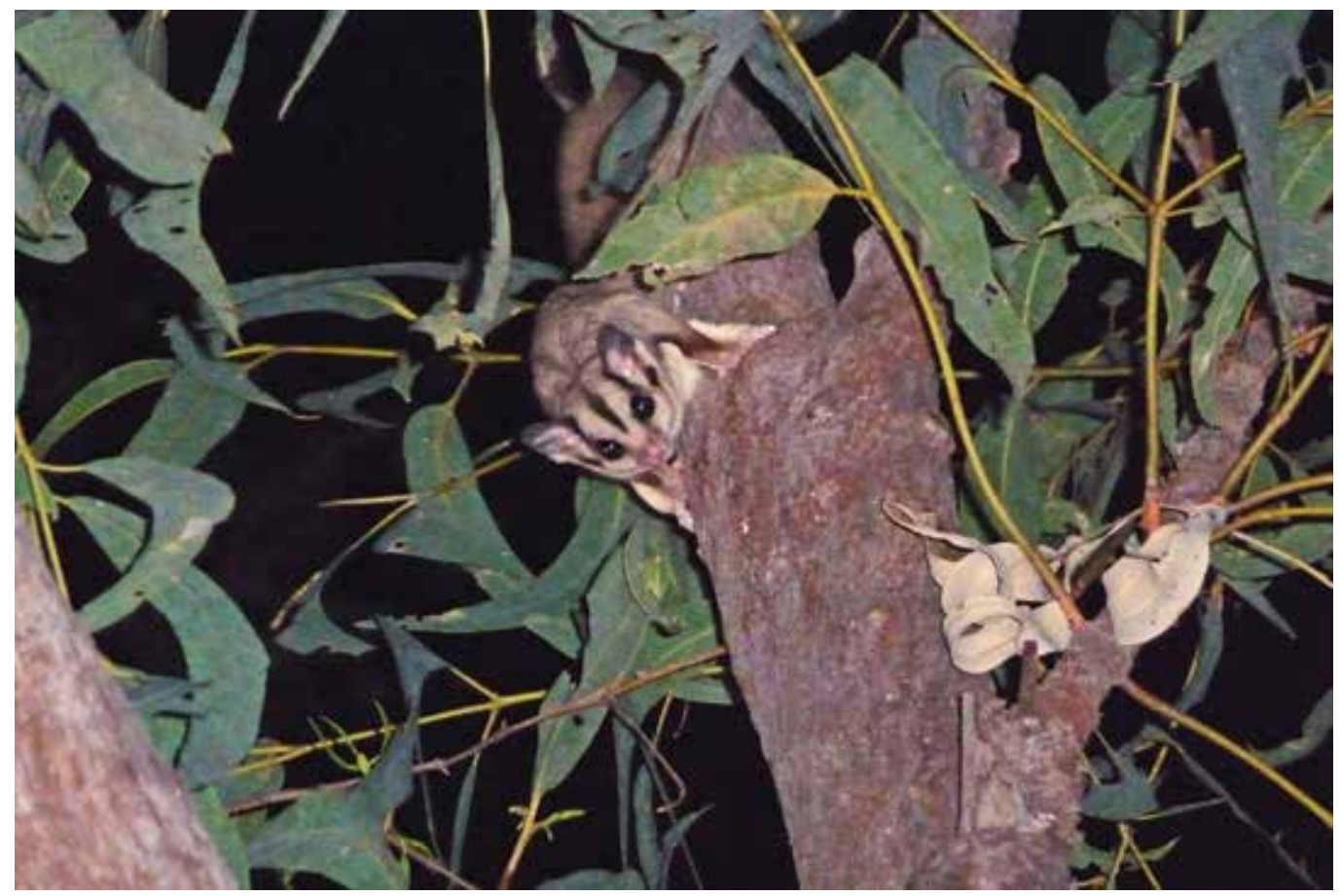

FIG. 78. Sugar Glider (Petaurus breviceps). Image-N. McKenzie.

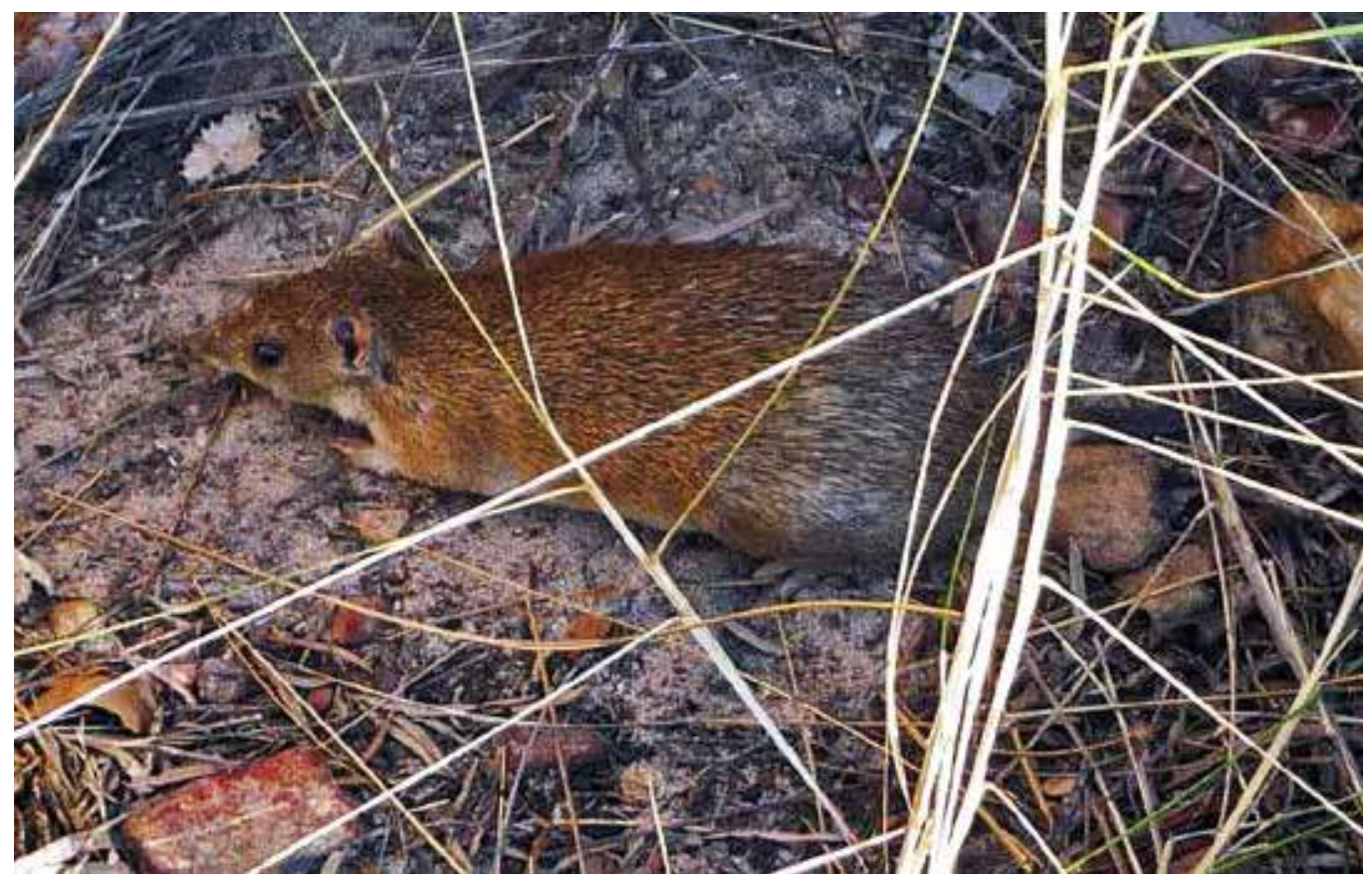

Fıg. 79. Golden Bandicoot (Isoodon auratus). 


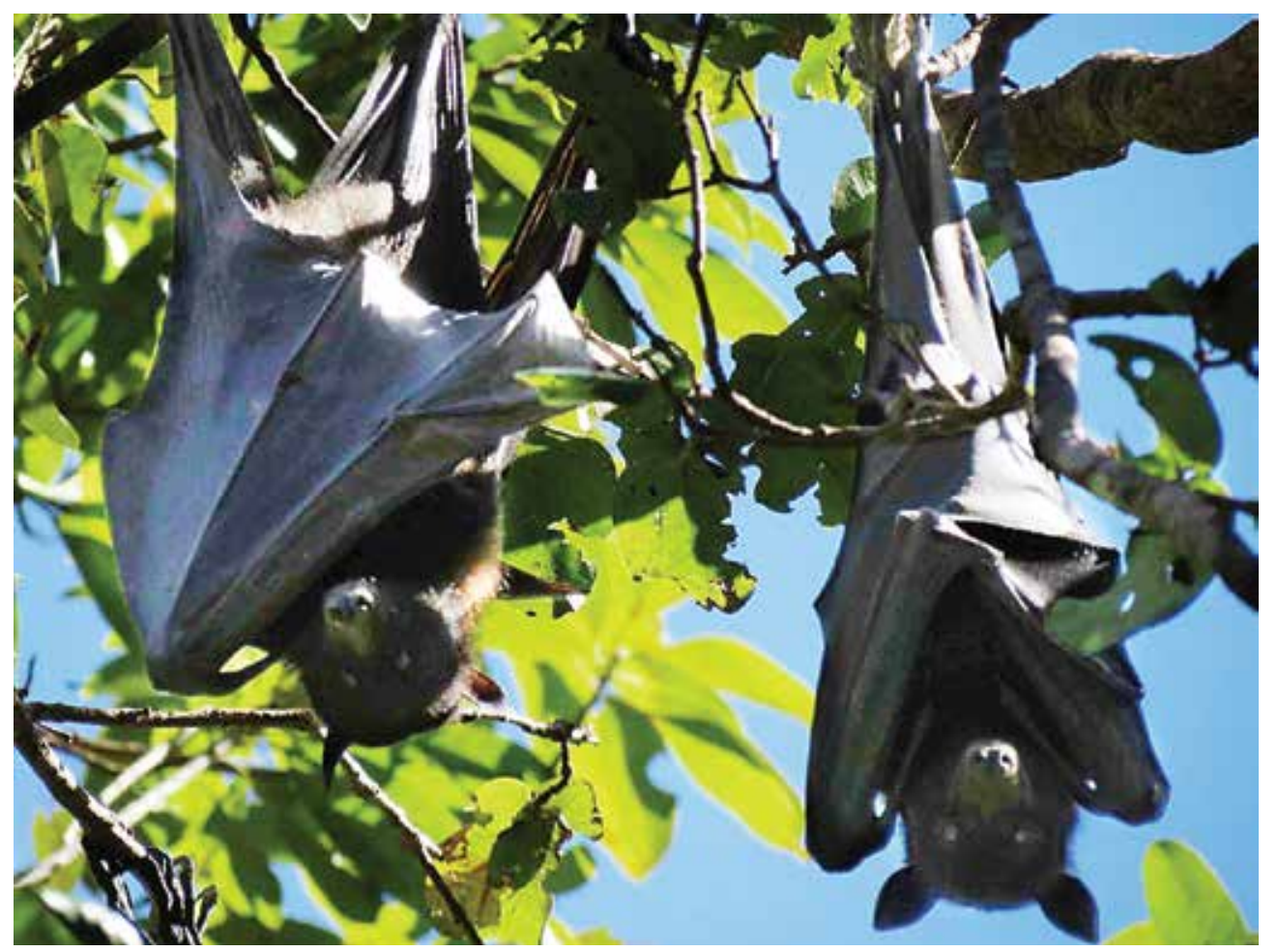

FIG. 80. Black Flying Fox or Niimanboorr (Pteropus alecto).

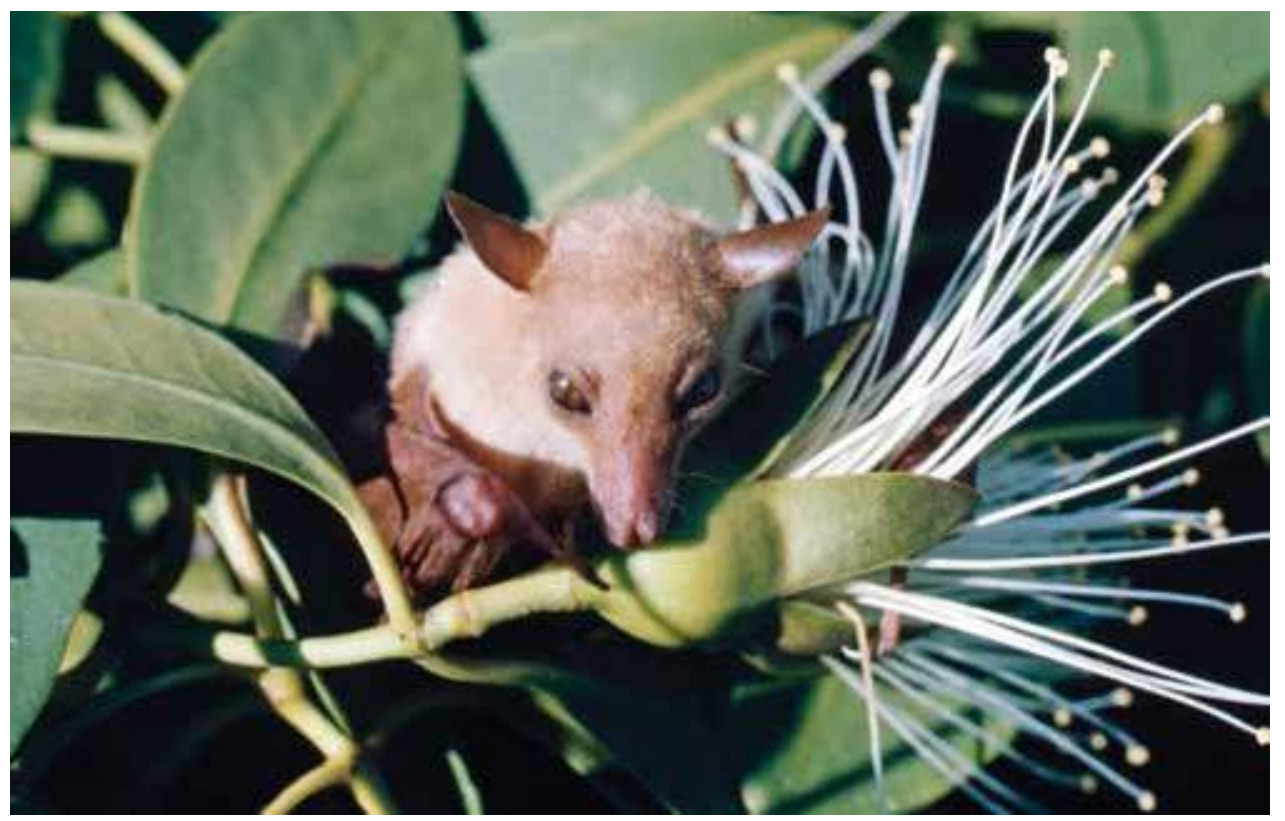

FIG. 81. Blossom Bat (Macroglossus minimus) feeding on flowers of the mangrove, Sonneratia alba. 


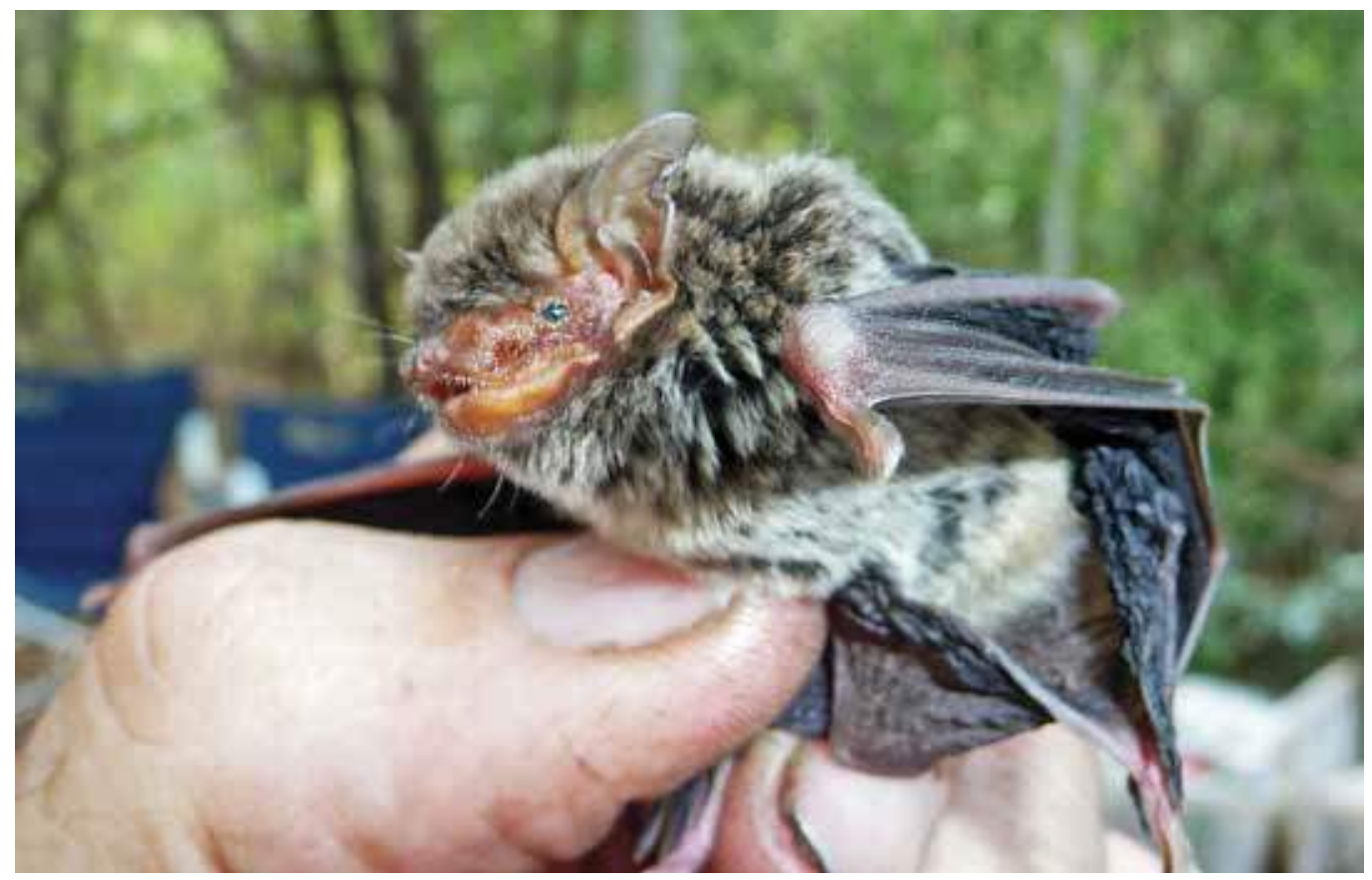

Fig. 82. Yellow-lipped Cave Bat (Vespedelus douglasorum). Image - N. McKenzie.

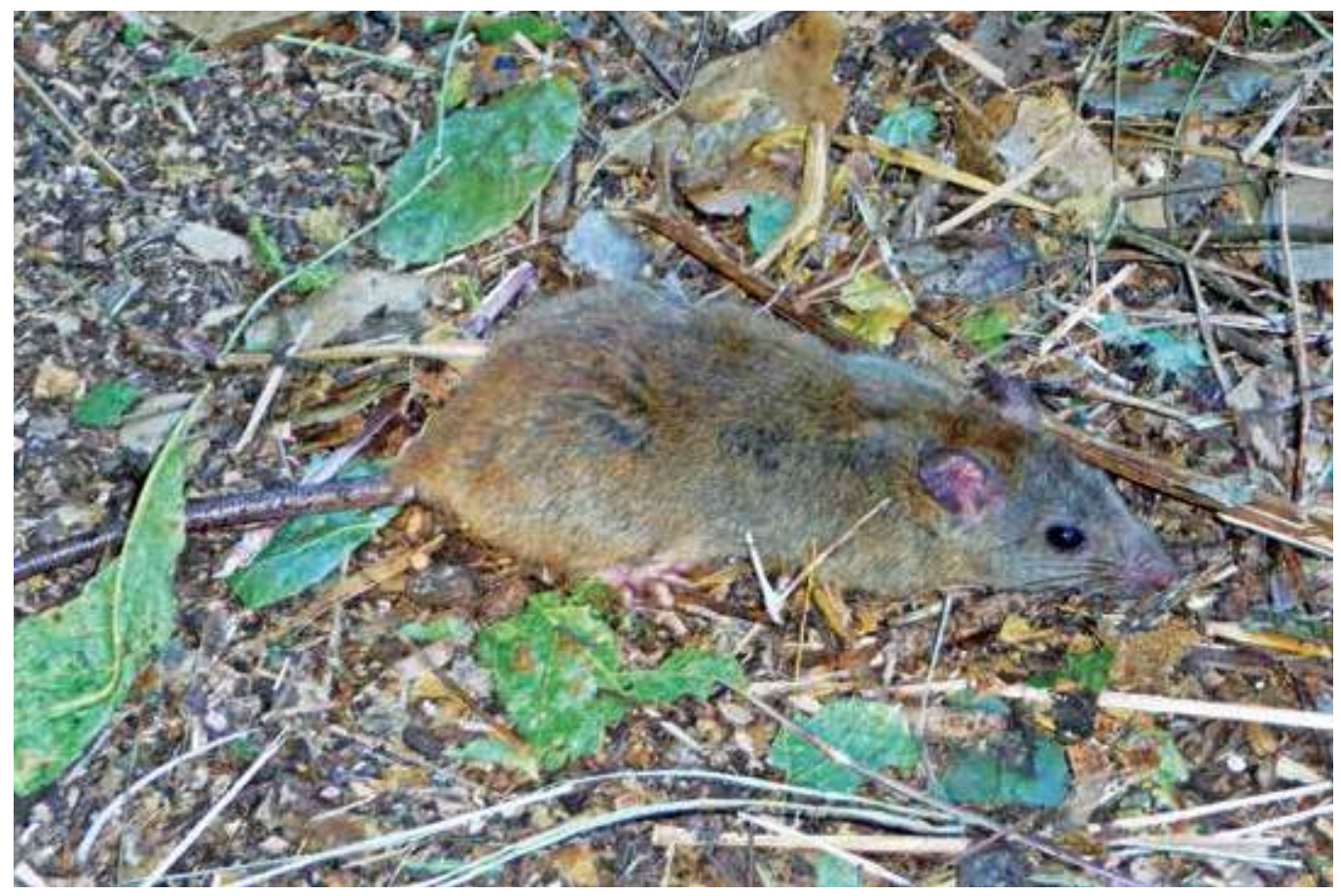

FIG. 83. Grassland Melomys (Melomys burtoni). Image—N. McKenzie. 


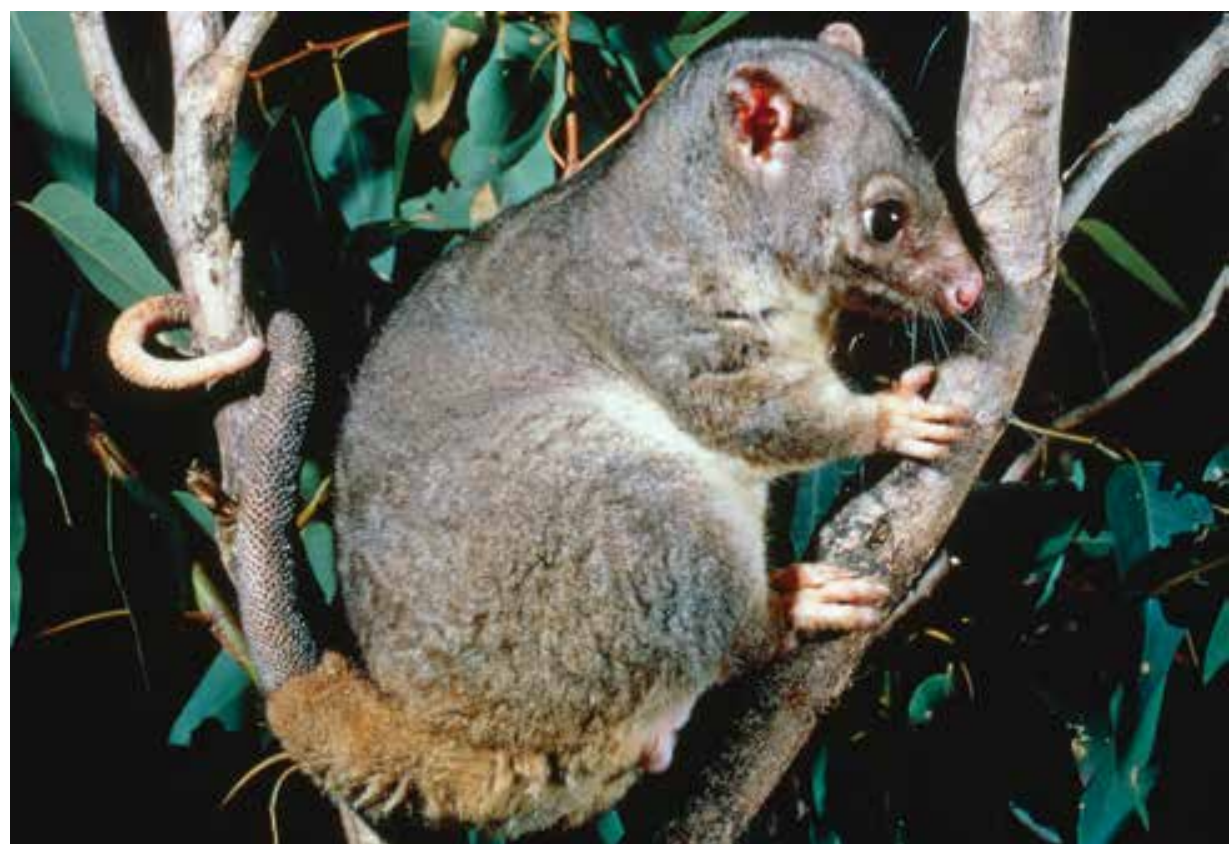

FIG. 84. Scaly-tailed Possum (Wyulda squamicaudata). Image-B. Wells/DBCA.

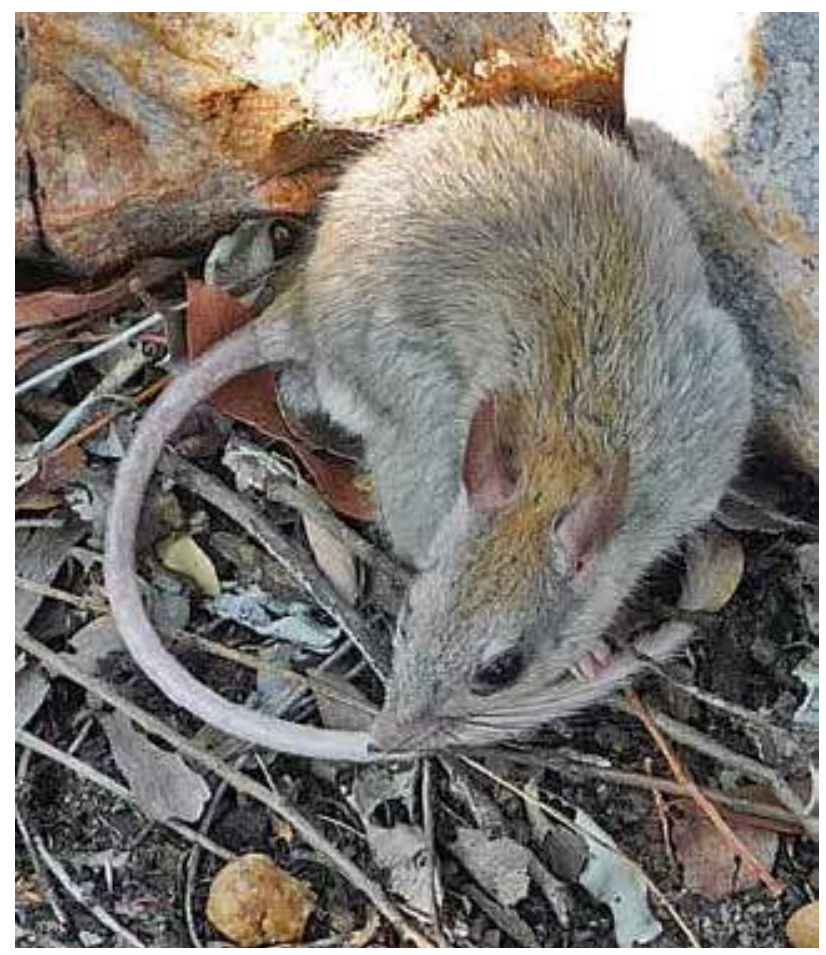

FIG. 85. Golden-backed Tree Rat (Mesembriomys macrurus). Image—N. McKenzie. 


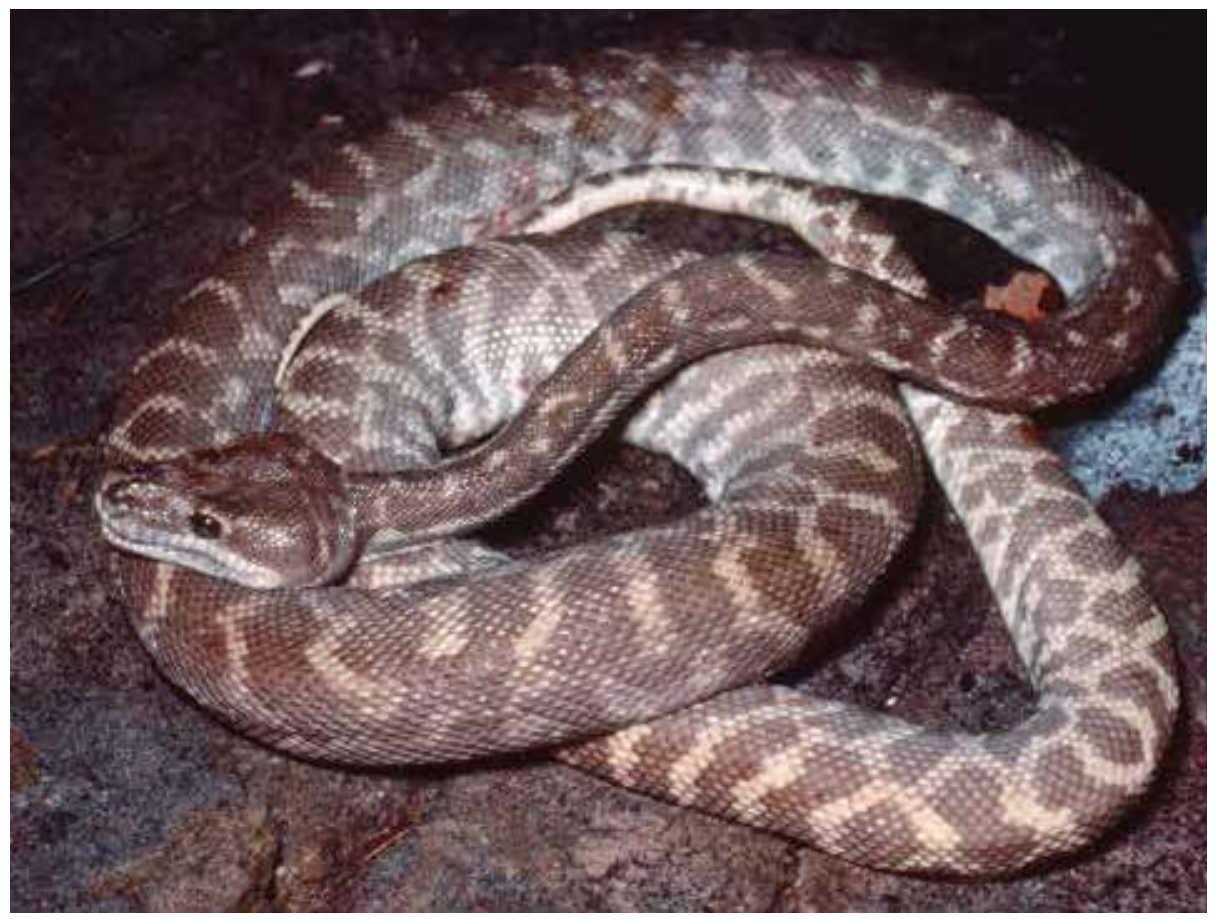

FIG. 86. Rough- scaled Python (Morelia carinata), a species endemic to the rainforest patches of Kimberley. Image—R. Johnstone, WA Museum.

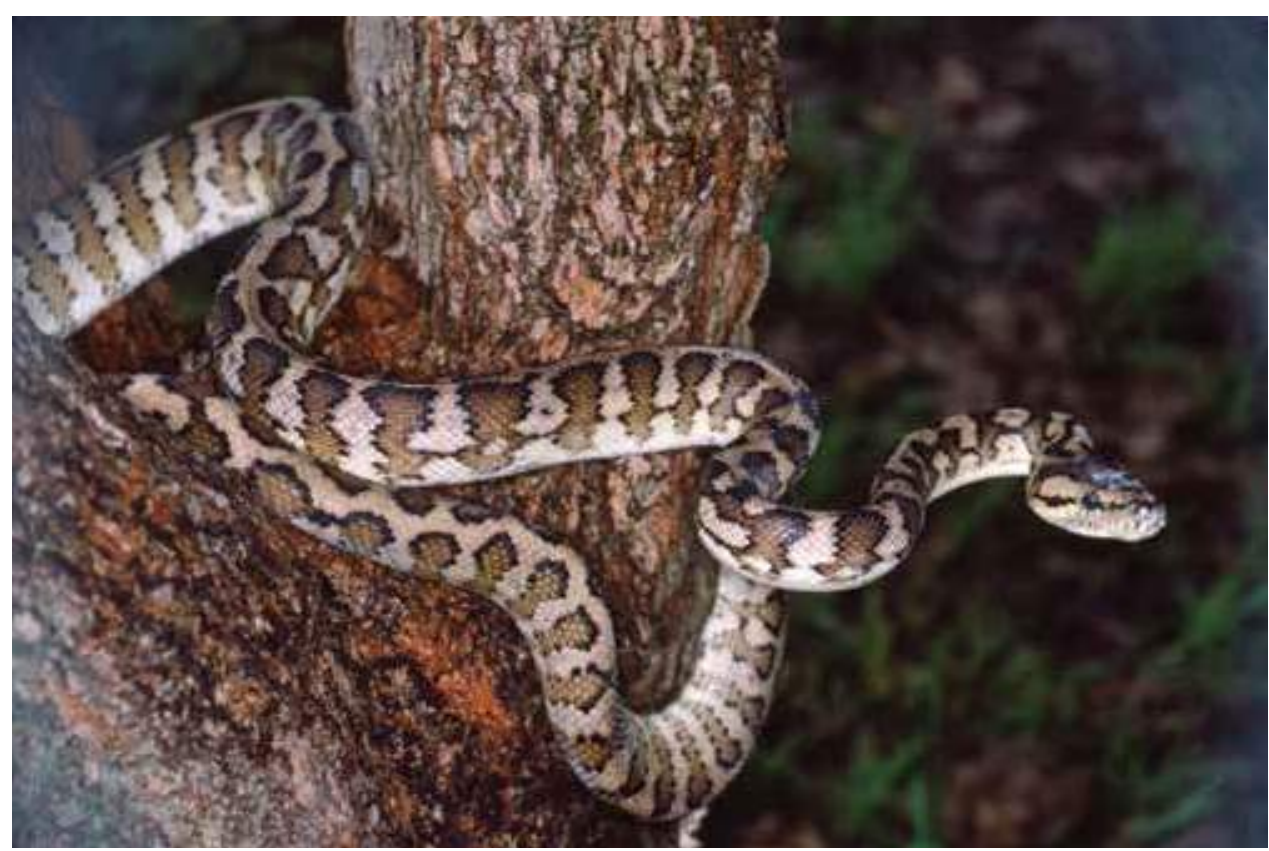

FIG. 87. Carpet Python (Morelia spilota variegata), common in rainforest across northern Australia and extending into New Guinea. Image - R. Johnstone, WA Museum. 


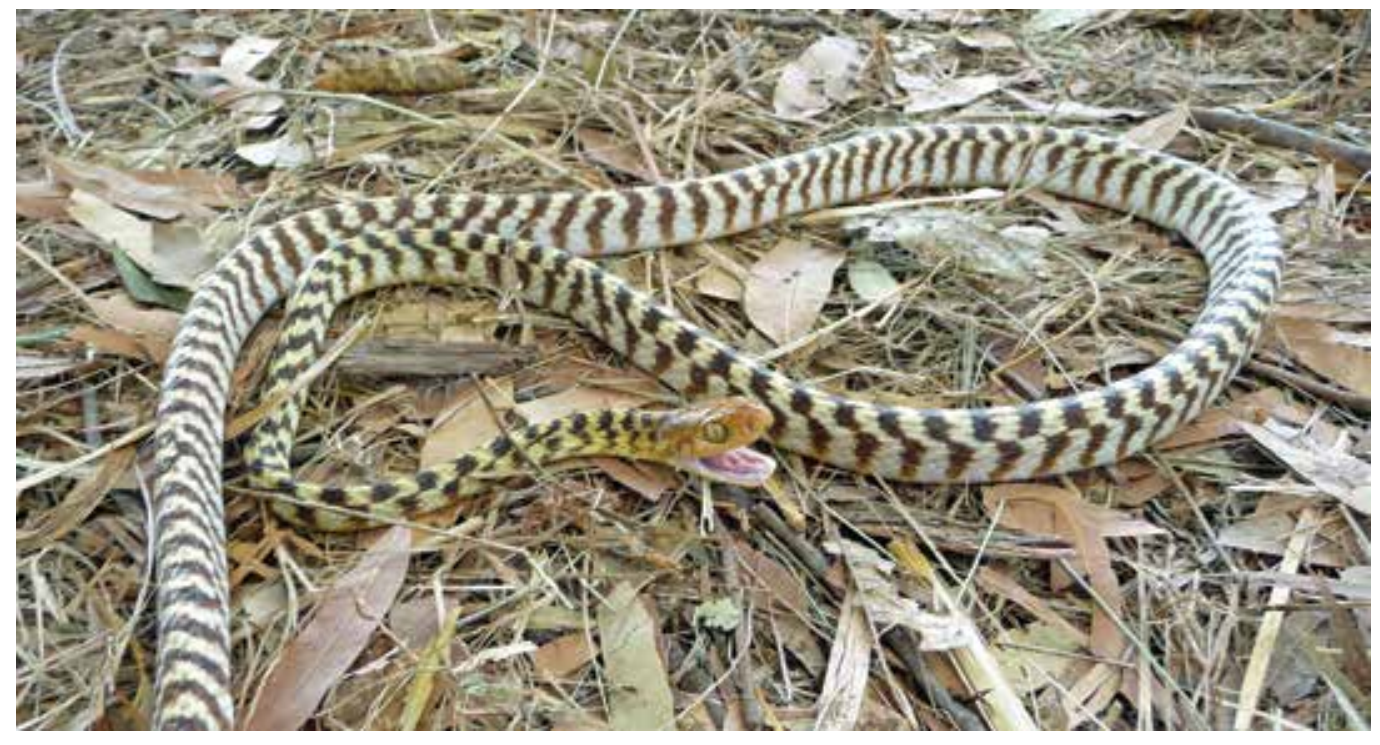

FIG. 88. Brown Tree Snake (Boiga irregularis), widespread species common in rainforest across northern Australia, extending into New Guinea and Indonesia. Image-N. McKenzie.

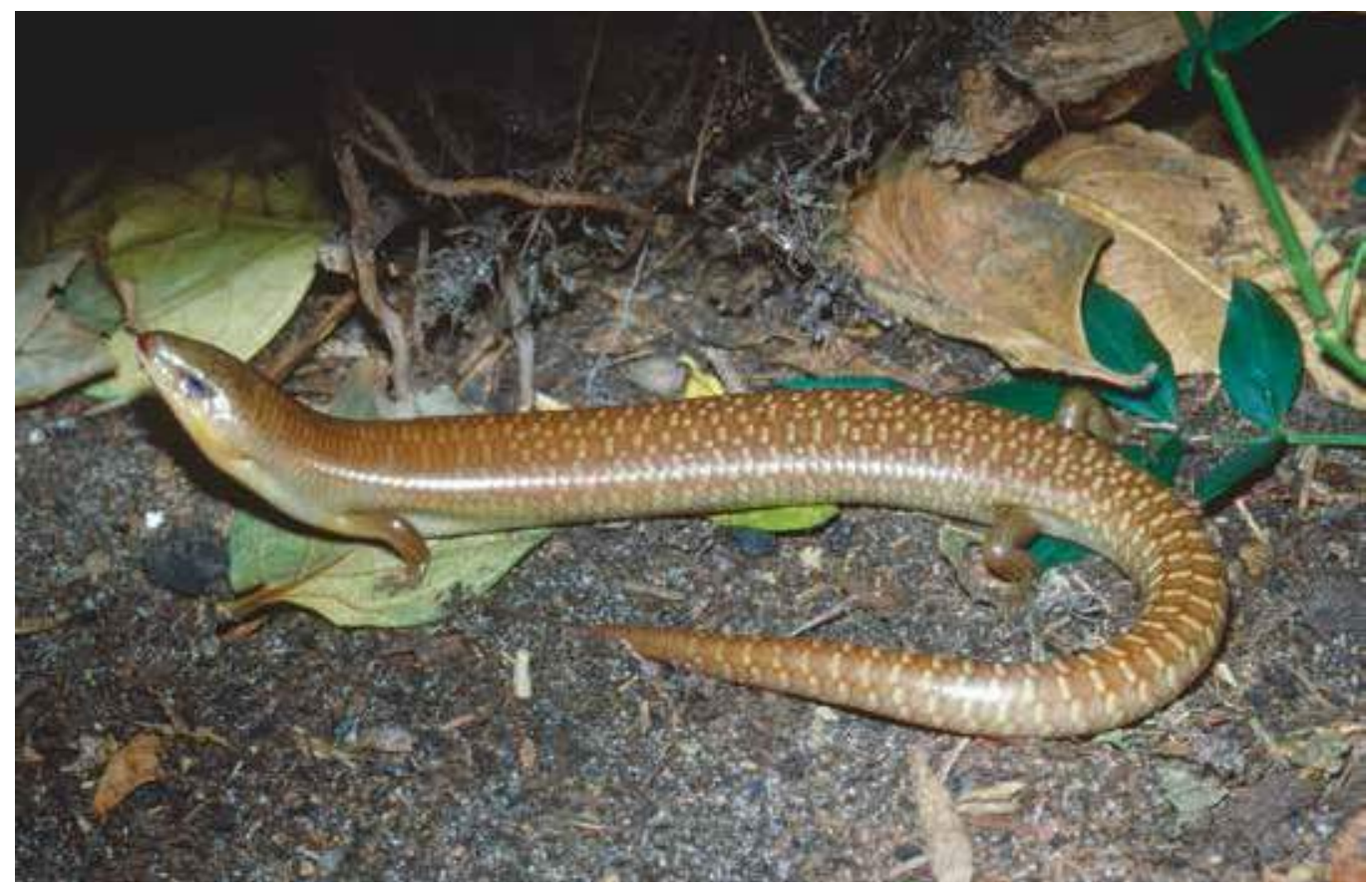

FIG. 89. Giant Slender Blue-tongue (Cyclodomorphus maximus), a skink found in rainforest patches in the far north Kimberley. Image-R. Johnstone, WA Museum. 


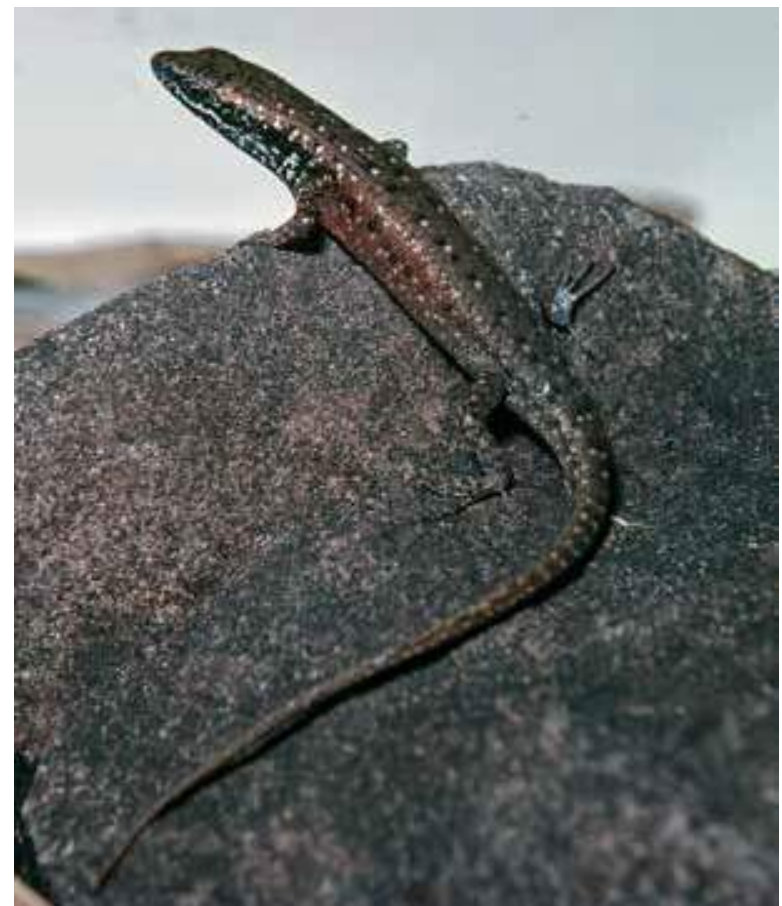

FIG. 90. Rough Brown Rainbow Skink or Johnstone's Carlia (Carlia johnstonei), is a Kimberley endemic, very common in Kimberley rainforest patches. Image-N. McKenzie.

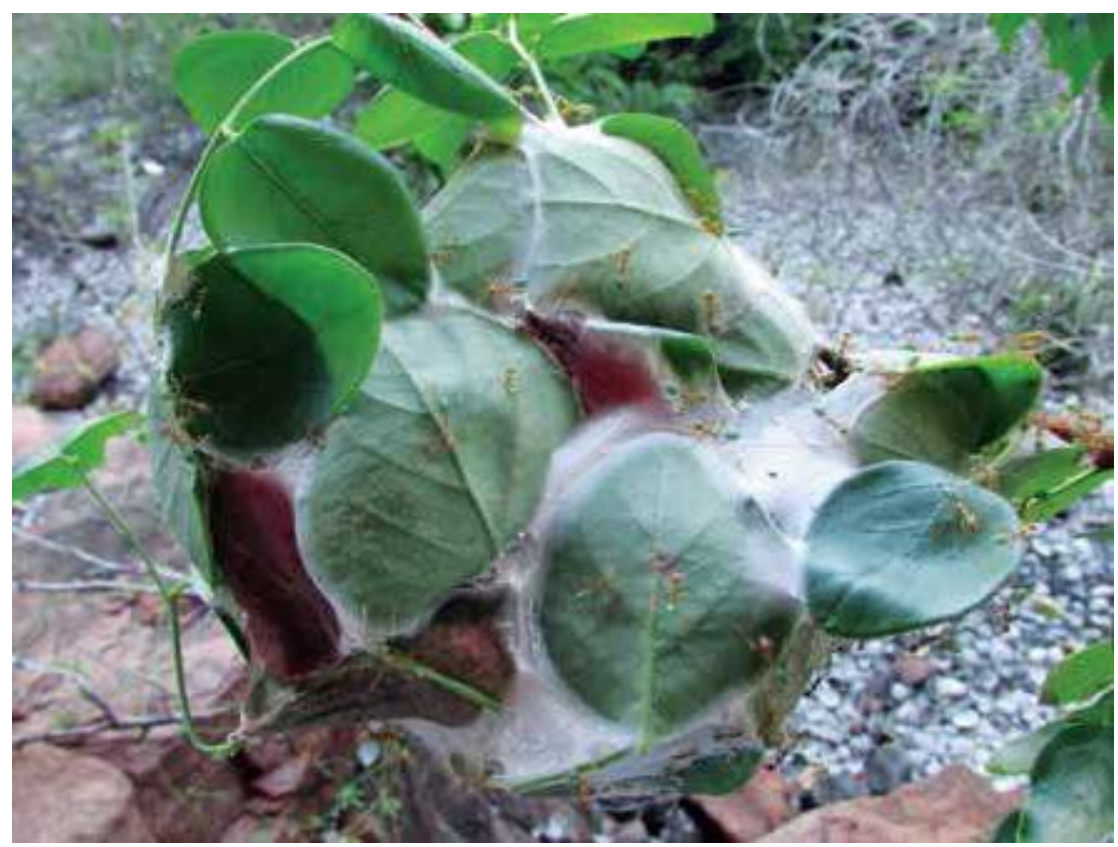

FIG. 91. Balloon-shaped nest of Green Ants (Oecophylla smaragdina). Image-T. Willing. 
atmospheric and forest floor humidity, the drying up of freshwater streams and pools, diminished plant growth, scarcity of flowers and fruits, and cooler temperatures (especially at night in inland areas) all combine to suppress insect activity.

\section{THE LARDER IN THE KIMBERLEY MONSOON RAINFOREST LANDSCAPE}

For Aboriginal people rainforests are important sources of seasonal fruits, berries, yams and timber for carving as well as traditional medicines (Kenneally et al. 1996). Nyul Nyul, Yawuru, Bardi Jawi, and Bardi Jawi Oorany women ranger groups are being taught to collect, store and propagate culturally significant seeds and endangered plants to help protect the biodiversity in the Broome and Dampier Peninsula region (Jones 2016). The project is bringing western science and traditional knowledge together. Bardi Jawi Oorany ranger coordinator Debbie Sibosado was quoted as saying "It's really important so we learn to know what to do in the Kartiya (white-fella) way, learn the common names, scientific names, so that when we're speaking to people, we all know what we're talking about." After decades of indifference, Australians are looking more favorably on native rainforest plants as food sources (Lethlean 2017). Examples include Finger Lime (Citrus australasica), Gubinge (Terminalia ferdinandiana), Macadamia (Macadamia spp.), and the Peanut Tree (Sterculia quadrifida).

The purpose of both ex situ and in situ conservation of plants and their genetic resources is that they may be used now and into the future (Stoutjesdijk 2013). Some rainforest plants are a rich source of various medicinal chemicals such as alkaloids, amides, flavonoids, lignans, sterols and terpenes etc. The genus Zanthoxylum, represented in the Kimberley by the Indian Prickly Ash (Z. rhetsa) has been described as "a stockpile of biological and ethno-medicinal properties" and has been popularly used traditionally (outside Australia) in different ethno-medicines for different ailments (Medhi \& Bhau 2013). The native Dutchman's Pipe (Aristolochia acuminata), a vigorous scrambling vine, is common in the rainforests across northern Australia extending north into the tropics. Although used widely in SE Asia, the Philippines and China for medicinal purposes its use in Australia is prohibited for supply, sale, or use in therapeutic goods. Aristolochia species and its particular components known as "aristolochic acids" have been linked to severe kidney damage and urinary tract cancer (Australian Government 2017).

However, some of the bush foods in the monsoon rainforest thickets in the Broome area are claimed to have been subjected to bio-piracy. Bio-piracy occurs where people have not sought consent and have not agreed to share benefits where they have used both a biological resource and/or a traditional knowledge from an indigenous group. It has been claimed by Daniel Robinson (Mills 2015) that in 2007 a major cosmetic company in the United States applied for a patent on the compounds found in Gubinge (Terminalia ferdinandiana). The Texan cosmetics company, Mary Kay Inc., claimed that the combination of extracts from Kakadu Plum and acai berry produce "synergistic effects" that benefit the skin, due primarily to the high concentration of vitamin C in the plum extract (https://www.google.com/patents/US20130149401). Robinson filed a formal challenge to the patent with IP Australia (https://www.ipaustralia.gov.au/) but pointed out the company had not contravened any legislation (Powell \& Murdoch 2010). In 2011 Mary Kay withdrew its patent application. The Protocol to the Convention on Biological Diversity (1993 Article 8j) requires companies that use flora or fauna in their products to acknowledge their origin and share the profits with Indigenous peoples and local communities whose knowledge made the development of these products possible. Interestingly, the United States is not a signatory to the Convention, so American companies such as Mary Kay are not subject to the obligations created by the Protocol.

\section{MANAGEMENT OF THREATS TO KIMBERLEY MONSOON RAINFORESTS}

The northwestern Kimberley, to date, has not been heavily impacted by human development. However, the Kimberley has vast geological resources, being endowed with oil, gas and rich mineral deposits of bauxite, lead, zinc, nickel and diamonds (Tyler et al. 2012). With any resource projects, there are concerns about the environmental impacts of these extractive activities, including impacts on natural systems, human health, scenery, recreational enjoyment, and other "ecosystem services." Exploiting these could have adverse impacts on the biota of the region and present an ever-increasing challenge for conserving biodiversity in the Kimberley (Carwardine 2011; Jackson 2017). 
The north Kimberley is recognized as a stronghold for declining native mammals and an Australian biodiversity hotspot for endemic plants, snails, reptiles, frogs and mammals. To maintain this biodiversity "The Kimberley Science and Conservation Strategy" (McKenzie et al. 2009) was released in 2011. An important part of the strategy is the "Landscape Conservation Initiative" being implemented through partnerships between the Department of Parks and Wildlife, now Department of Biodiversity, Conservation and Attractions (DBCA), traditional owners, pastoralists and other key land managers including the Australian Wildlife Conservancy (AWC). This initiative aims to:

"Retain the current near pristine biodiversity and landscape values of the north-west Kimberley by preventing significant impacts from introduced animals, weeds, inappropriate fire regimes and other identified threats."

European settlement in the Kimberley brought large changes to the ecology and fire regimes as well as a complete decline in traditional Aboriginal land management practices, particularly burning.

There is little doubt that too-frequent, extensive and hot fires have had a strong influence on the localized distribution and boundary characteristics of monsoon rainforests across northern Australia (Figs. 92-96). Tropical savannas constitute the world's most fire-prone biome, and they support a biota with a high degree of resilience in relation to fire. The high frequency of periodic lightning strikes in October and November (the end of the dry season and the onset of the wet season), when little rain has fallen and most of the ground vegetation is very dry and flammable, suggests that fires occur naturally in the region during these months. Periodic large fires are a feature of extensive, fire-prone landscapes, and such landscapes are not only highly resilient to them but the fires can be important in promoting biodiversity (Bradstock 2008; Keane et al. 2008). The size and shape of persisting patches often reflects the level of protection offered by surrounding landforms and vegetation. Patches surrounded by rock outcrops, creeks, rivers or bordered by ocean are less frequently burned than those adjacent to savanna woodlands, with their abundant seasonally dry grasses. Regular or

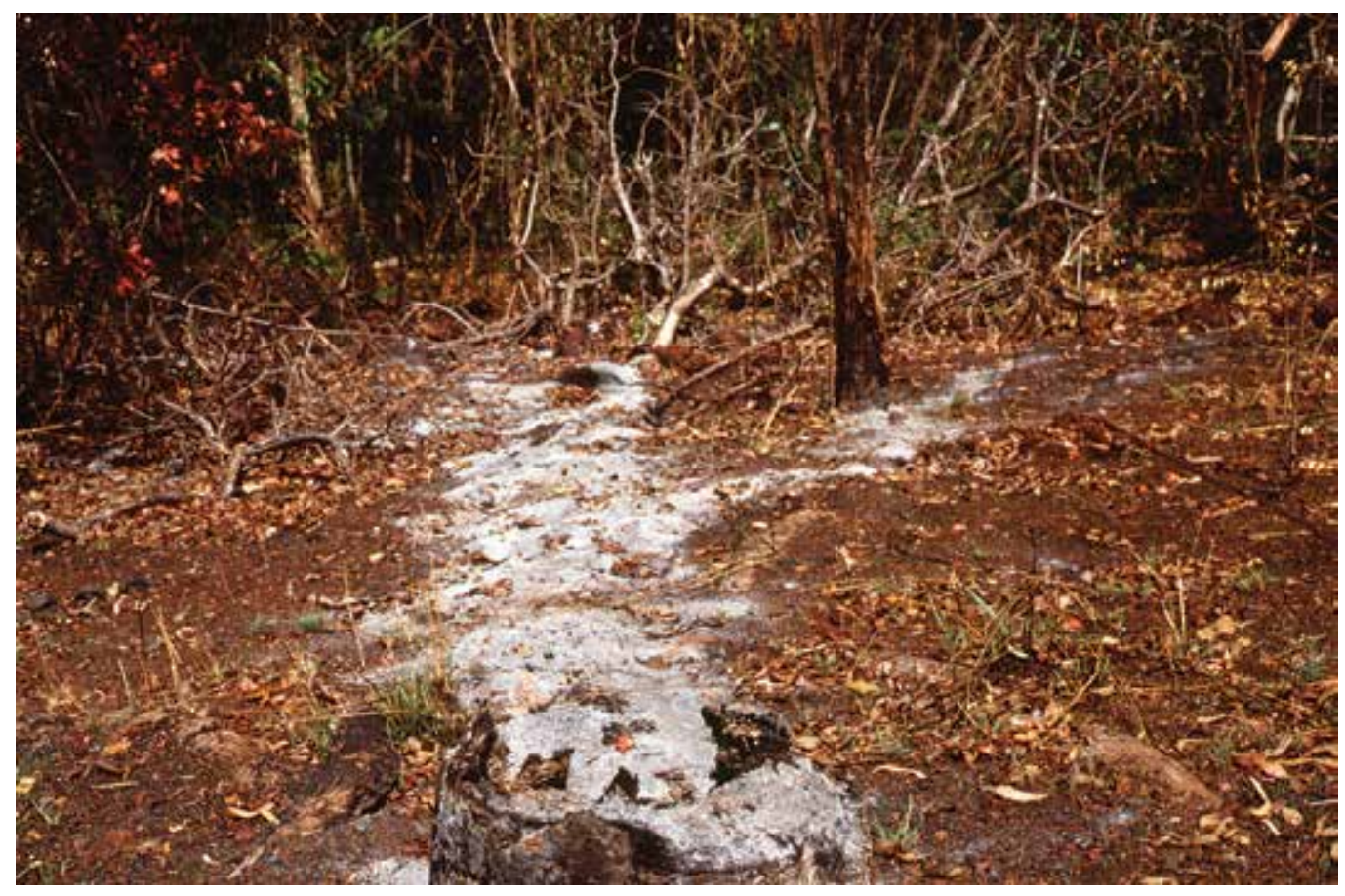

FIG. 92. Ash trail from burnt tree leading into monsoon rainforest patch at Lone Dingo, Mitchell Plateau, north-west Kimberley. 


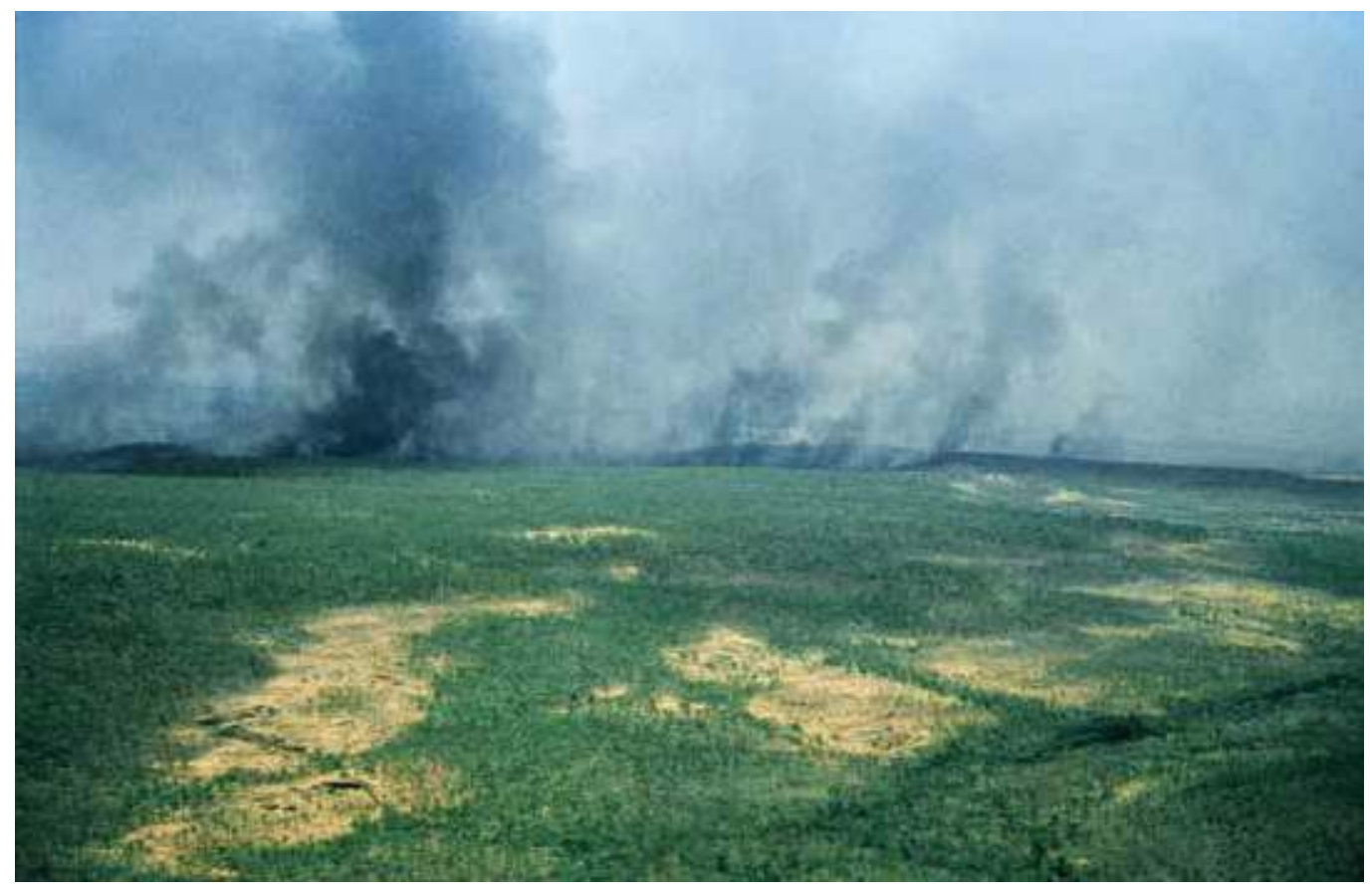

FIG. 93. Uncontrolled wildfires burn across the Kimberley landscape.

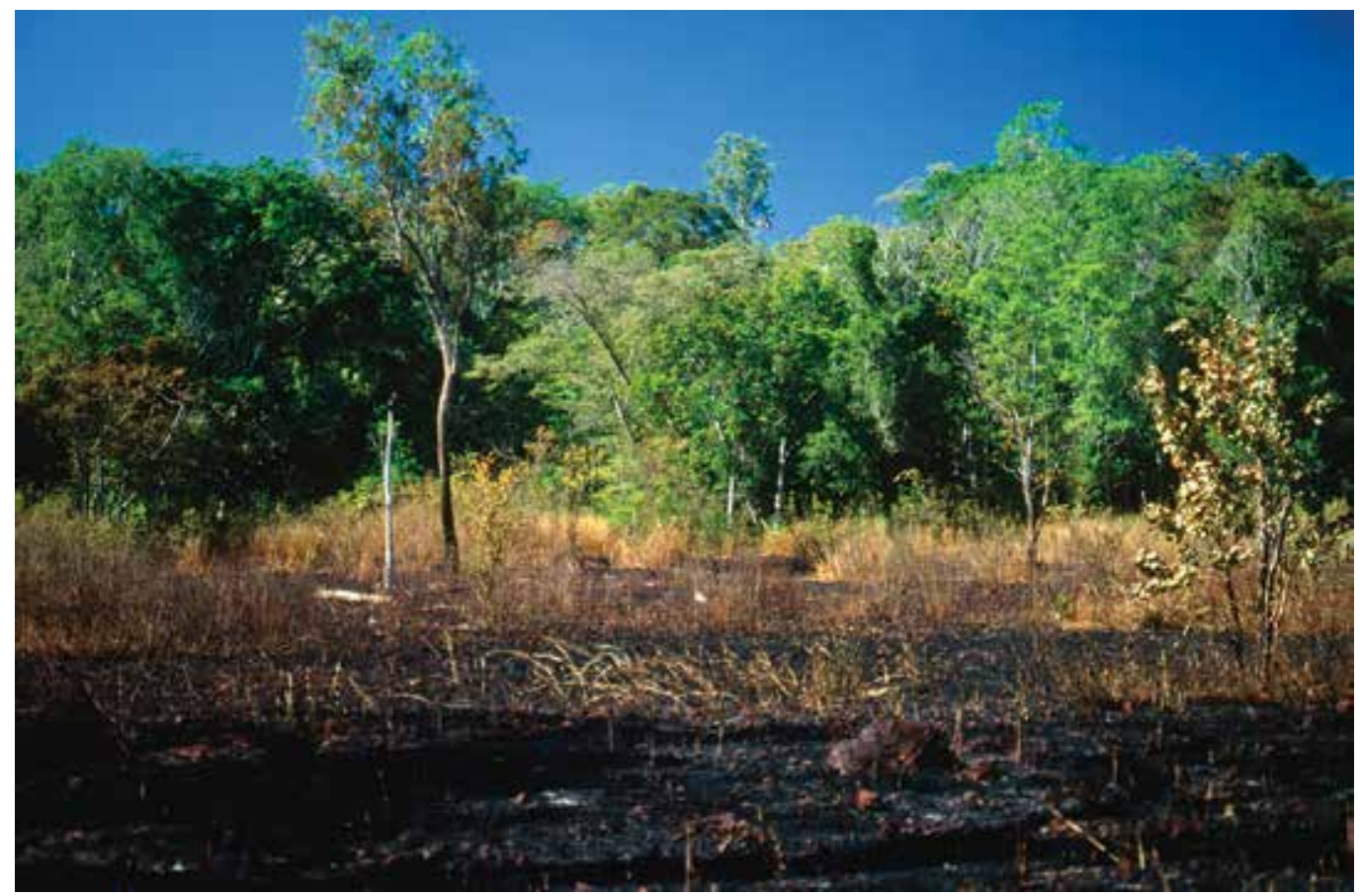

FIG. 94. Edge of a monsoon rainforest patch showing the result of a hot fire in the surrounding savanna woodland, Crusher vine thicket, Mitchell Plateau.

This document is intended for digital-device reading only.

Inquiries regarding distributable and open access versions may be directed to jbrit@brit.org. 


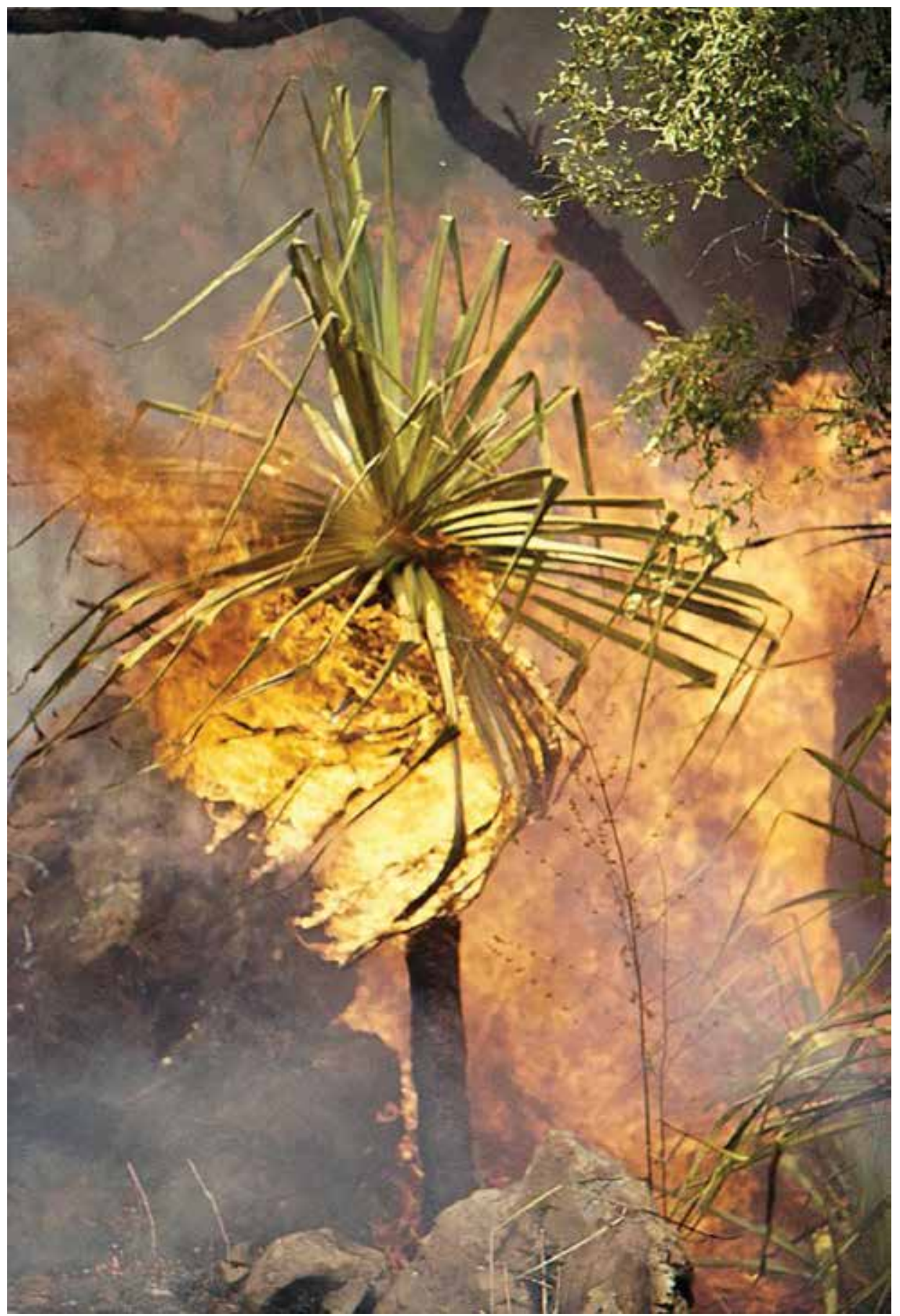

FiG. 95. Repeated hot fires can cause enormous damage to savanna and monsoon rainforest vegetation. 


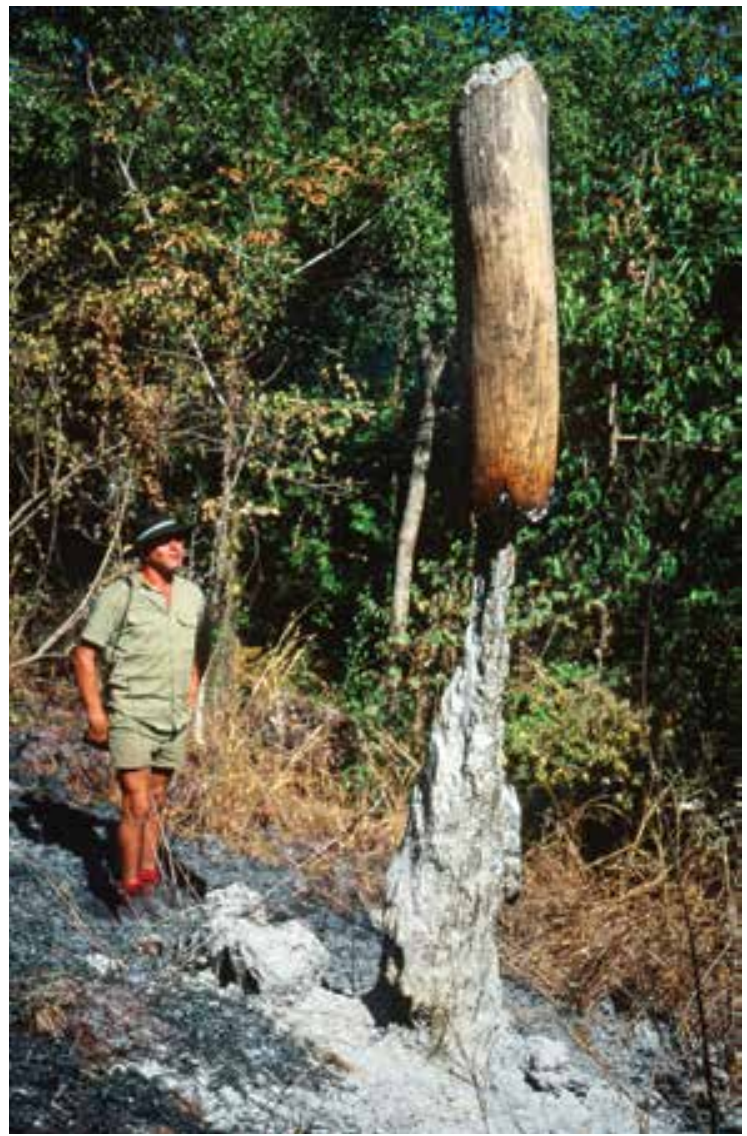

FIG. 96. The late Joe Raudino on a Landscope Expedition at Mitchell Plateau showing where fire has intruded into a monsoon rainforest patch. The fire can smolder for sometime and then reignite, causing more damage.

intense wildfires break the dense cover of foliage that helps to maintain the moisture balance and local environment for rainforest species.

Although officially banned by government regulations in many countries, use of fire in Australia plays an important role in a range of savanna livelihood and biodiversity management applications (Russell-Smith et al. 2013). Prescribed burns are being conducted in the late wet and early dry season to create a mosaic of burnt and unburnt areas across almost 20 million ha of the north Kimberley. The resulting patchwork effect from these prescribed burns reduces the amount of fuel available and has resulted in fewer large, intense and damaging fires later in the dry season in recent years. By managing the landscape-scale threats we can also protect many of the plants and vegetation communities, including monsoon rainforest (Keighery 2014). Research by Ondei et al. (2017) using historic and recent aerial photos (1949, 1969, and 2005) found that most rainforest patches on the Mitchell Plateau had expanded by $10 \%$ in the last 50 years despite the severe wildfire events of that period. During that same period, monsoon rainforest on the Bougainville Peninsula had expanded by $60 \%$. This was attributed to the absence of cattle on the Peninsula and less frequent fire. At a narrow isthmus on the Bougainville Peninsula (now part of the Uunguu Indigenous Protected Area) a boundary fence has been constructed to keep straying feral cattle and donkeys from the area. This is helping to conserve one of the largest continuous patches of monsoon rainforest in the Kimberley. The cattle-free and rarely-burnt Bougainville 
Peninsula may be important for biodiversity, by offering more long-unburnt habitats for large numbers of threatened small to medium-sized mammals and fire-sensitive floristic elements rarely found elsewhere in northern Australia (Ondei et al. 2017).

The observed expansion of some rainforests into savannas suggests that rainforest saplings could have traits that enable them to survive in the savanna environment, including recovering from infrequent fires (Ondei et al. 2016a). They hypothesized that rainforest expansion has occurred in the north Kimberley in response to the wetting trend in northern Australia over the last century, together with increasing atmospheric carbon dioxide, but that the expansion is strongly influenced by the combined effects of fire and feral cattle. Cattle use rainforest patches for shade, resulting in the understory being trampled opening them up to invasion by both flammable savanna grasses and introduced grasses (McKenzie et al. 2009). Climate change resulting in severe heatwaves, could result in further pressure on rainforest patches by promoting more severe fires. As temperatures increase more cattle will be driven to seek shade (Vogel et al. 2017). Studies by Ondei et al. (2016b) have corroborated previous studies that suggest moist climate, infrequent fire and geology are important stabilizing factors that allow rainforest fragments to persist as islands in a sea of savanna.

Concerted efforts to better manage fire and feral animals (cattle in particular) by DBCA, the Kimberley Foundation (on Theda and Doongan pastoral stations) and the AWC are improving the status of threatened and other species in the Kimberley. There are several fire projects in the Kimberley that implement prescribed burning and which have substantially reduced the scale of late dry season wildfires. These include ECOFire run by the AWC on Central Kimberley pastoral lands and the Fire Abatement projects run by four Native Title groups (Wunambal Gaambera, Dambimangari, Willinginn, and Balanggarra) together with Kimberley Land Council. Indigenous ecological knowledge and science are increasingly combined to inform land management decisions. Many of these projects generate Australian Carbon Credit units through application of Australia's formal savanna burning methodology (Russell-Smith et al. 2009; Russell-Smith et al. 2013; Australian Government 2015b \& Vigilante et al. 2017). Monitoring and evaluation has found there was a very strong relationship between mammal abundance and diversity with fire frequency, with areas being burnt more than once every two years having far fewer animals. Sites in which the fire frequency was less than one in five years (such as parts of Prince Regent National Park) had the highest rates of mammal trap success. There are still areas of high cattle density and high fire frequency, such as the King Edward River area, where improvements need to occur (Radford et al. 2013). Rainforests are generally considered as refugia from the extensive savanna fires of the Kimberley and are thus critical to providing an avenue for recolonization after fire (Figs. 97-98).

Six years after it was first found in Western Australia in 2009, the invasive Cane Toad (Rhinella marina) has become established in the East Kimberley. Cane Toads are toxic as eggs, tadpoles and adults, and threaten to poison a wide range of Kimberley wildlife. They can impact on native species via poisoning through ingestion, predation and competition for habitat. The species is listed by the World Conservation Union as one of the world's worst 100 invasive alien species. There is minimal natural predation of Cane Toads in Australia and their movement across the Kimberley cannot be stopped using any of the methods currently available (Department of Parks \& Wildlife 2014).

Rapid urban expansion at Broome has resulted in domestic dogs harassing wildlife and this has led to a decline in the number of Agile Wallabies (Macropus agilis) feeding in the monsoon rainforest at Minyirr Coastal Park, located behind the sand dunes at Cable Beach (Tim Willing, pers. comm.) (Fig. 99).

Weeds are a major threat to Australia's biodiversity as they can result in hotter, more frequent fires, modify soil characteristics or compete directly with native species (Keighery 2015). In the coastal monsoon vine thickets of the Dampier Peninsula the most serious weed is Siratro or Purple Bean (Macroptilium atropurpureum), a fast-growing climber that grows over the trees and shrubs, smothering most species and creating a fire hazard. More widespread in the Kimberley and also of concern is the Stinking Passionflower (Passiflora foetida), which smothers rainforest patches and can lead fire into the canopy causing tree deaths. These vines can form "sails" in the upper canopy that result in trees being uprooted during high winds associated with cyclones and other tropical storms, as well as providing fuel for subsequent fires (Figs. 100-101). 


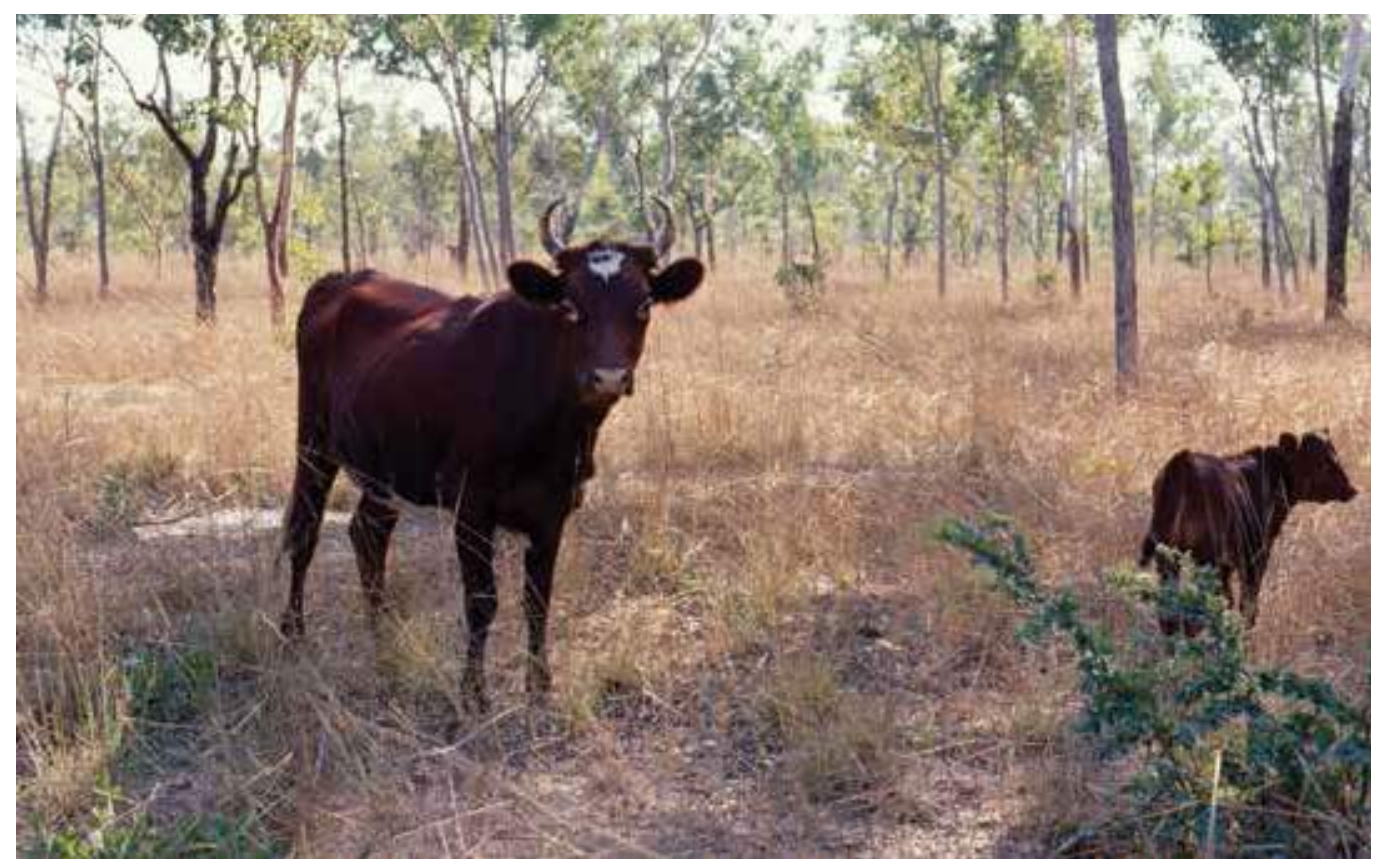

FIG. 97. Feral cattle have destroyed monsoon rainforest patches in the Kimberley.

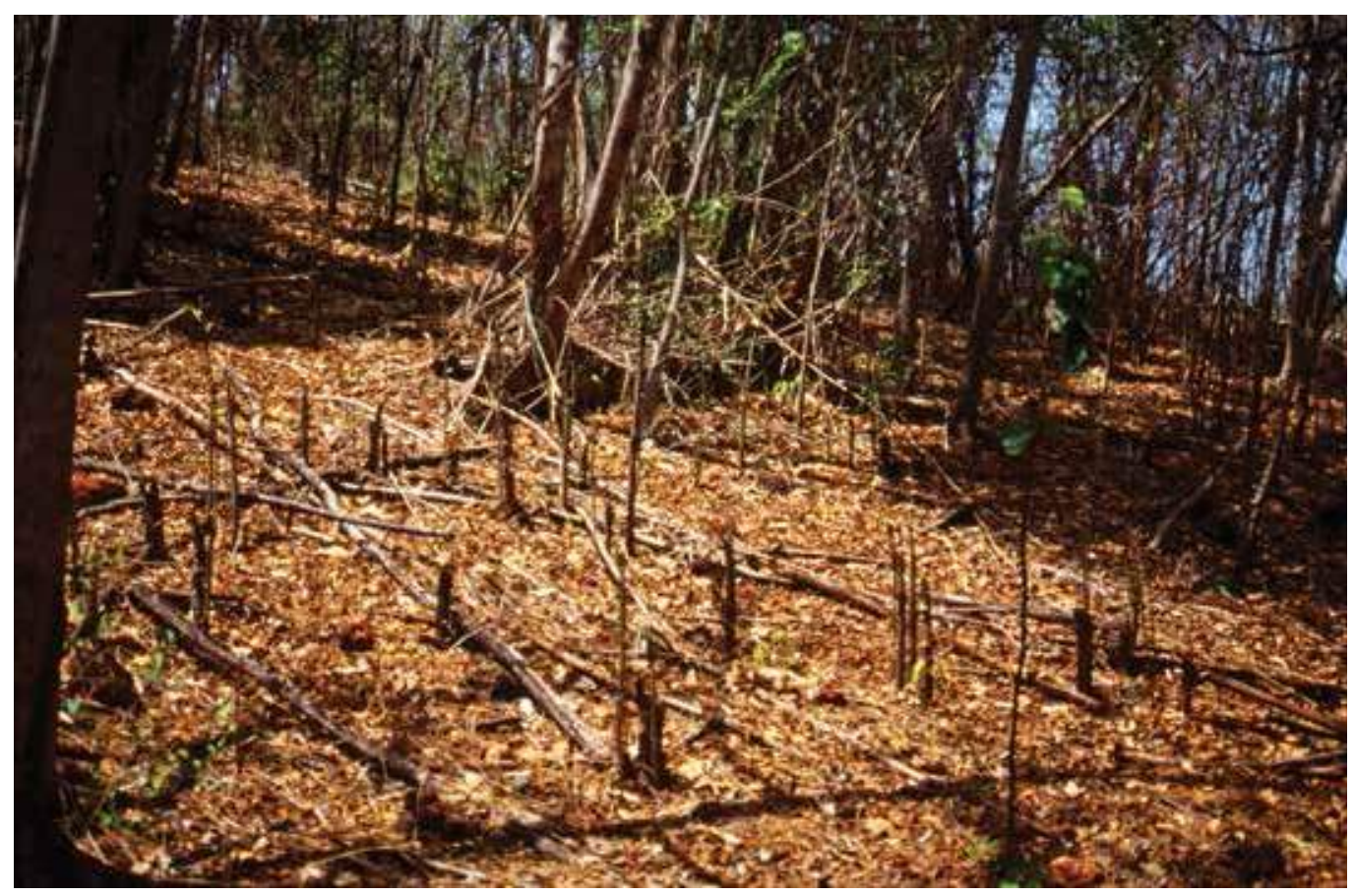

FIG. 98. Damage to a monsoon rainforest patch on Mitchell Plateau caused by cattle trampling and grazing. Cattle were first recorded on the Mitchell Plateau in 1976, moving in from adjacent pastoral leases established from the 1950s. 


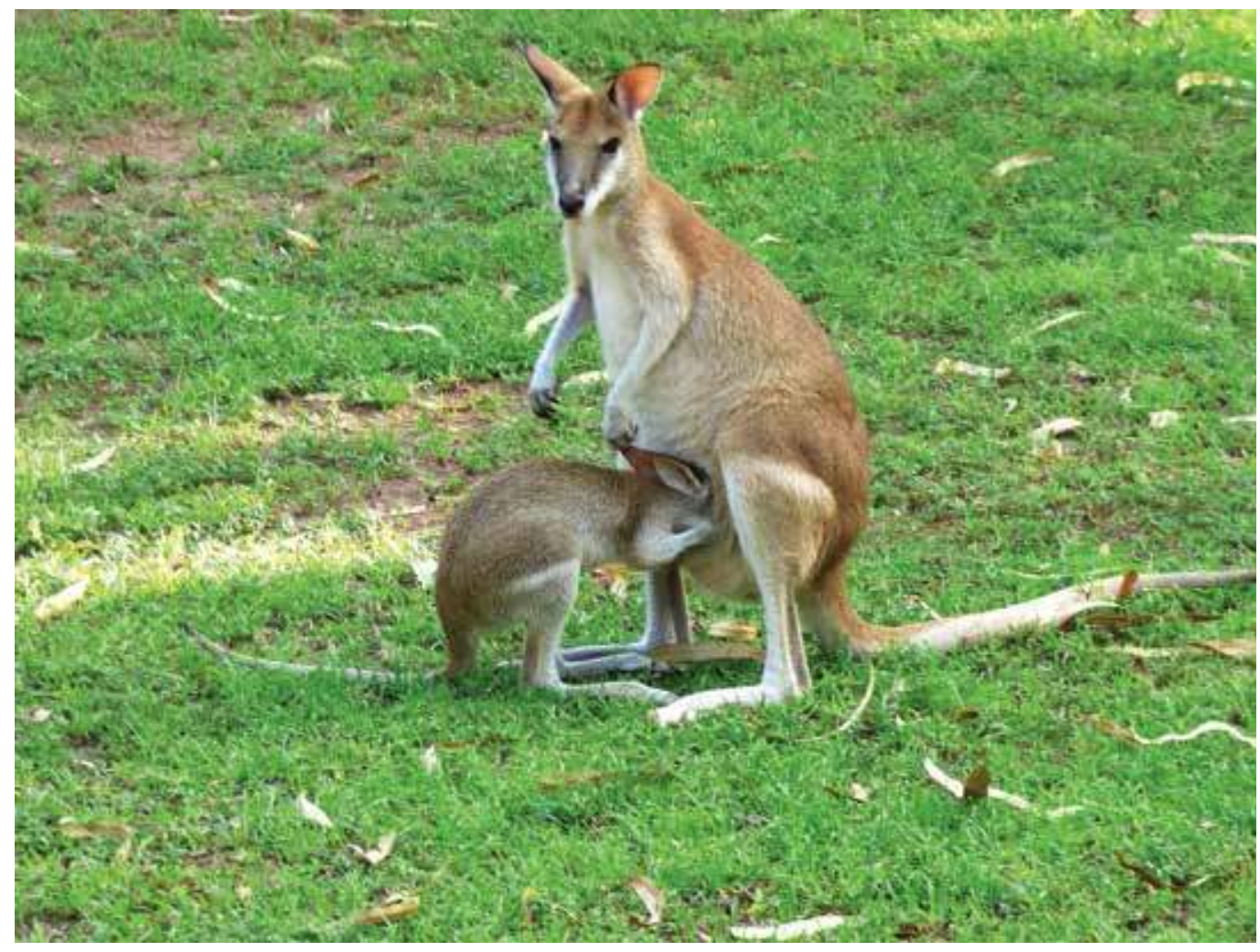

FIG. 99. The Boorroo or Agile Wallaby (Macropus agilis) with a joey. Their numbers have declined in the Broome monsoon forest due to harassment from domestic dogs.

On the Mitchell Plateau, the introduced Grader Grass (Cenchrus quadrivalvis) and Annual Mission Grass (Cenchrus pedicellatus subsp. unispiculus), are of concern. Annual Mission Grass and Grader Grass are listed as weeds of potential national significance. Annual Mission Grass is also listed as a high impact weed in the "Field Guide to Assessing Australia's Tropical Riparian Zones" and a key threatening process to biodiversity in Northern Australia. The main impact of both grasses is through high fuel loads, which are substantially greater than those of most native grasses (Australian Government 2012a).

\section{CONSERVING THE BIODIVERSITY OF TROPICAL MONSOON RAINFORESTS IN THE KIMBERLEY}

Mounting evidence of the Kimberley as a historical and ancient center of refugia warrants action from scientists, government, conservation agencies, Indigenous landholders and local communities to protect and conserve its unique biota, as well as the processes responsible for generating and sustaining it. In October 2014, the State Government Minister for Environment and Heritage, the Hon. Albert Jacob stated that "Biodiversity surveys assist Kimberley land management." He further went on to say "Surveys of animals and plants in key locations throughout the Kimberley are providing important information to help conserve the region's biodiversity" (Jacob 2014).

The Kimberley's extensive land-and seascapes provide a magnificent setting for a vast array of plant and animal species and the northwest Kimberley is acknowledged as one of 15 Australian biodiversity hotspots and widely regarded by researchers as one of the world's last great botanical frontiers (Department of Environment 2014). However, such a diverse and extensive region as the Kimberley also poses a formidable hurdle for scientists in determining the first among many questions that are essential to effective research and 


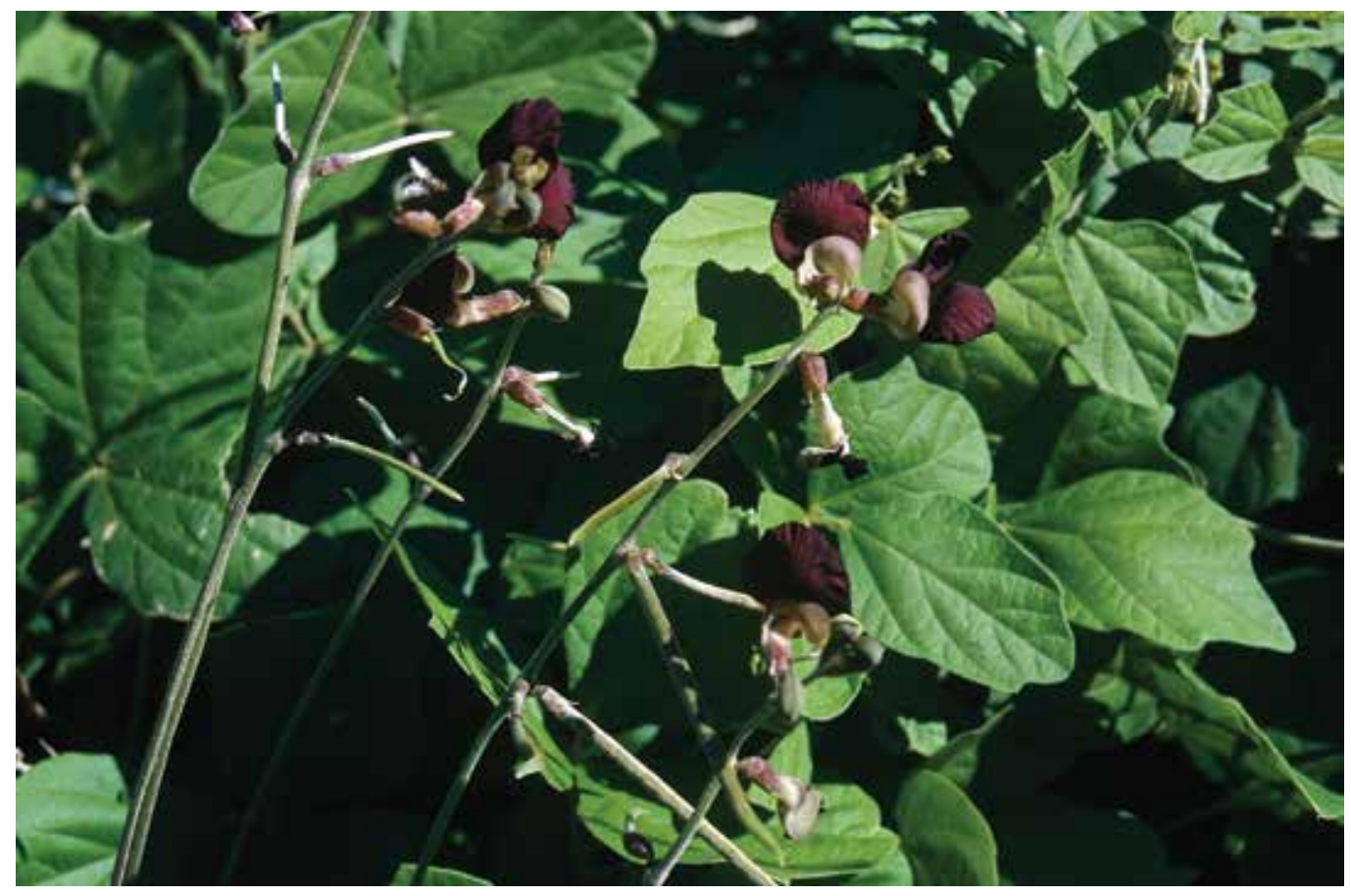

FIG. 100. The most serious weed affecting monsoon rainforest on the Dampier Peninsula is the legume Siratro or Purple Pea (Macroptilium atropurpureum), a fast-growing creeper that smothers vegetation and provides biomass for hotter fires.

conservation- "What occurs where?" A major emphasis of scientific research undertaken in the region by various organizations has been directed toward answering this pivotal question.

The high rainfall, near-coastal region of the northwest Kimberley has experienced no known extinctions to date (McKenzie et al. 2007), but several mammal species with formerly wider distributions have now contracted to this area including three of the Kimberley's four endemic species (Burbidge et al. 2008).

The Kimberley is currently recognized as a center of mega-diversity and micro-endemism, with the distributions of taxa undoubtedly shaped by changing climates, landscape and geomorphology. However, the lack of fine-scale sampling across the Kimberley and surrounding bioregions has hindered the development of our understanding of the biogeographical history of the region. Flooding in the wet season results in roads being closed for many months at a time. Much of the region is only accessible by helicopter or by boat from the sea. Limited access to this topographically rugged and remote area has largely restricted comprehensive assessments of its biodiversity, and only in recent years has the compositional complexity of its flora and vertebrate fauna been fully appreciated (Carwardine 2011). The major impediments to carrying out fine-scale sampling in the Kimberley are its remoteness, limited access and the lack of funding to carry out long-term monitoring. Cost-effective solutions to monitoring rainforest patches include technologies such as satellite monitoring, remote instruments (including camera traps), remotely piloted aircraft (RPAs or drones) and enlisting the power of citizen science to help fund research as demonstrated by the very successful Landscope Expedition to the Mitchell Plateau area in 2002 (Kenneally et al. 2003). Most important are the collaborative projects currently being undertaken with Aboriginal Traditional Owners.

Plants provide the structural and nutritional basis for habitats and ecosystems. The monsoon rainforest patches in the northwest Kimberley exist as fragmented islands in a sea of fire-prone savanna. It has been recognized that a predictive understanding of extinction might be obtained from island biogeography, since 


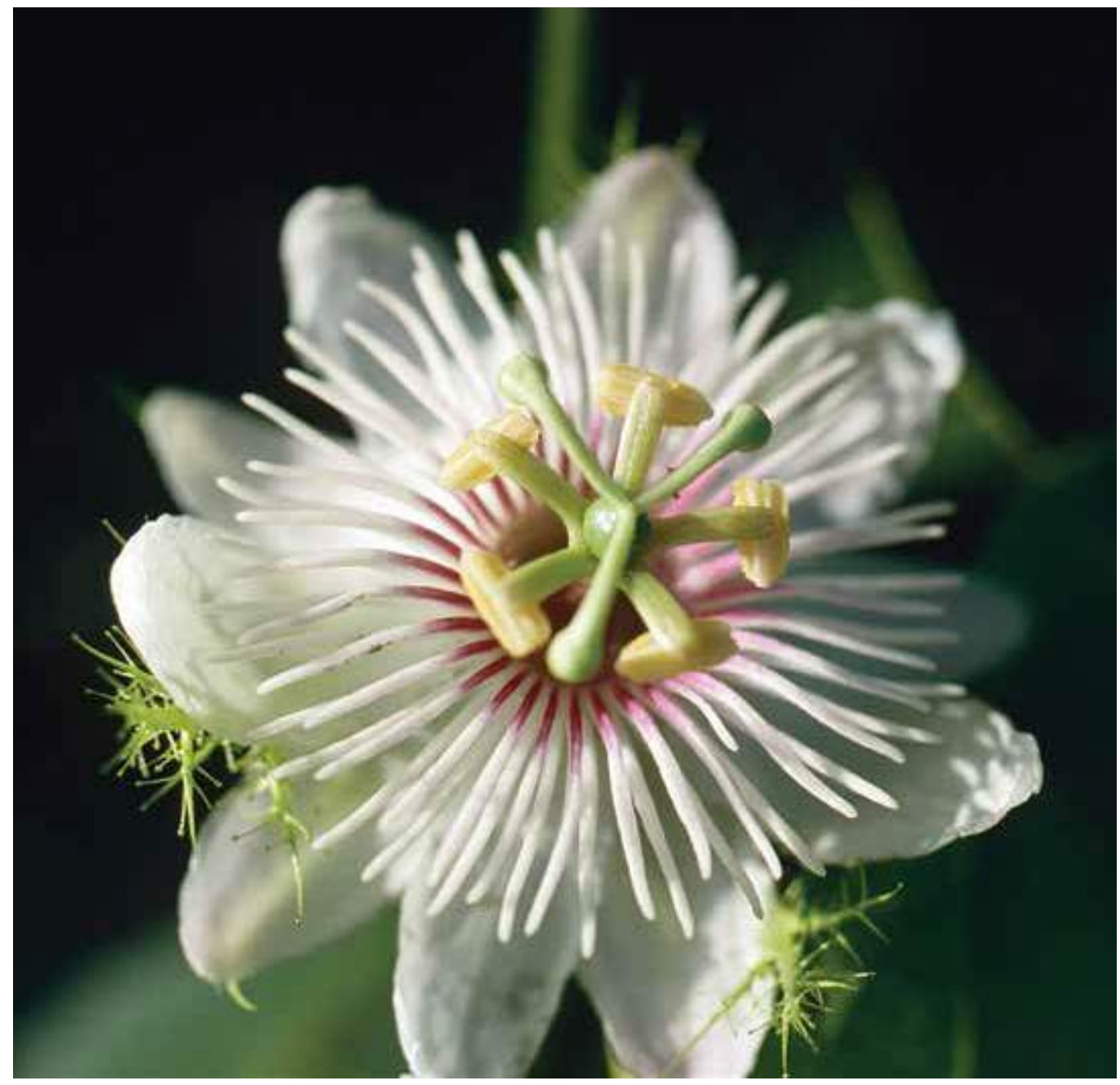

FIG. 101. Stinking Passionflower (Passiflora foetida) is an aggressive climber that smothers monsoon rainforest canopy and provides biomass for hotter fires. Its seeds are spread by birds and other animals.

refugia behave as islands for species dependent on natural habitat (Diamond 1976). Scientists have looked to islands for insights into the forces that shape biological diversity which include dispersal, invasion, competition, adaption and extinction (Mcarthur \& Wilson 1967). The importance of dispersal is increasingly being recognized for its fundamental role in the generation of biodiversity on islands (Cowie and Holland 2006). Much of island biogeography, and much of contemporary ecology, deals with changing distributions, patterns and interactions of flora and fauna communities. Until recently most references to diversity involved species level diversity and not the integrity of biological communities. Resource management has increasingly focused on the community level. These analyses and principles are not directed merely at saving endangered species, but rather at keeping the full complement of species and assemblages from becoming endangered (Davies 1984).

We have only intensively studied less than $10 \%$ of the 1,500 rainforest patches in the Kimberley. From these we have a reasonable understanding of the flora and vertebrate fauna assemblages but as previously 
noted all patches have their own unique mix of species. What we do not have a good understanding of is the non-vascular plants (lichens, bryophytes and fungi), and the majority of the invertebrate groups, particularly the less mobile species. What we do know, however, from research into land snails and earthworms is that species can be endemic within their own patch of rainforest.

The "Landscape Conservation Initiative" established by the State Government in 2011 as part of the "Kimberley Science and Conservation Strategy" aims to retain and enhance the high biodiversity and landscape values of the north Kimberley, an area of more than 65,000 square $\mathrm{km}$. Some of the key achievements of this strategy have been the removal of feral cattle, pigs, cats and horses from areas with high biodiversity values as well as undertaking prescribed early dry season burning to greatly reduce destructive late season fires (Department of Parks \& Wildlife 2014). Some Kimberley monsoon rainforests are located within National Parks or other Conservation Reserves and are therefore afforded some protection. Others are located within Aboriginal Reserves and it may be appropriate to establish Indigenous Protected Areas (IPAs) for these sites. An IPA is an area of land/or sea country which has been voluntary declared to be a protected area by its Indigenous Traditional Owners. IPAs are managed by Indigenous peoples according to international guidelines and are recognized by Commonwealth, State and Territory Governments as part of Australia's National Reserve System. The establishment of IPAs could avoid past practices where Indigenous peoples' rights and interests were either overlooked or forced to fit with the structures and processes promoted by government (Kerins 2016).

The focus of conservation should be to protect monsoon rainforest patches across the Kimberley and they need to be managed across different tenures, both within and outside any reserves that might yet be established. Remote does not always imply pristine. At first glance, the size of these ancient, often massive Kimberley landscapes can mask their fragility (McKenzie et al. 1991). In the past, much of the management of this vast area was one of "benign neglect." The monsoon rainforests of the Dampier Peninsular have protection under State and Federal biodiversity legislation. The larger, more complex patches in the northwest Kimberley have limited legislative protection when, in 2011, the West Kimberley was included on the National Heritage List, pursuant to section 324J of the Environment Protection and Biodiversity Act 1999 (Commonwealth of Australia 2011). Monsoon rainforests of the northern Kimberley coast and islands were specifically cited for their outstanding heritage value to the nation for their evolutionary refugial role that has resulted in high invertebrate richness and endemism. The National Heritage listing does not change land ownership and does not affect Native Title. Management of National Heritage Listed places remains with the current landowner or manager. The listing of the West Kimberley as a National Heritage place helps ensure that heritage values are part of the decision-making, and that heritage protection will be balanced with the social and economic aspirations of the Kimberley community (Australian Government 2012b).

Only the monsoon thickets of the Dampier Peninsula and the Theda Swamp, Walcott Inlet and Roe River rainforest swamp forests are listed in Western Australia as "Threatened Ecological Communities." Rainforests at Point Spring, Napier and Ningbing Ranges as well as "Vegetation Association 717," defined by John Beard (1979) as "mixed tropical deciduous forest," are listed as Priority Ecological Communities. In Western Australia, the Environmental Protection Agency (EPA) has issued a guidance statement for the protection of mangroves along the Pilbara coastline. Guidance Statements are generally developed by the EPA to provide advice to proponents, and the general public, about the minimum requirements for environmental management which the EPA would expect to be met when the Authority considers a proposal during the assessment process (Environmental Protection Authority 2001). Such a guidance statement could be prepared for Kimberley monsoon rainforest patches.

\section{THE VALUE OF A KIMBERLEY TROPICAL BIODIVERSITY RESEARCH CENTRE}

After nearly five decades of investigating monsoon rainforests and their complexity it has become apparent to me that there is a fundamental need to continue to investigate their biogeographic relationships, biodiversity and potential for bioprospecting as well as ensuring their effective conservation and management. There is an urgent requirement to instill an appreciation of their natural and cultural values within the landscape and 
across the wider tropics in partnership with Aboriginal Traditional Owners. Until we fill-in these missing pieces of the jigsaw, we will not have a comprehensive picture of Kimberley monsoon rainforest or a comprehensive understanding of their contribution to this biodiversity hotspot.

The lack of a dedicated Kimberley research center for integrated tropical studies limits the ability of scientists to carry out long-term projects. Large areas of the Kimberley are private lands managed by traditional Aboriginal owner's and require special collecting permits and protocols administered by the Kimberley Land Council (KLC) on behalf of the traditional owner's or direct negotiation with the traditional owner's themselves (Pepper 2014). The opportunity to conduct research with traditional owners is both respectful and appropriate and can lead to productive outcomes for both researchers and Indigenous communities. Aboriginal Elders' knowledge of the natural environment comes from acute observation in the course of their daily lives (Laurie 2010).

An appropriate research center, jointly managed and with the agreement and cooperation of traditional owners would give scientists the ability to carry out effective year-round monitoring in an area prone to wetseason cyclones with destructive winds and flooding rains. Approaches have been made in the past to the Western Australian State Government for the establishment of such a center. In October 1983, when Conzinc Riotinto of Australia (CRA) planned to mothball its bauxite project on the Mitchell Plateau, the Western Australian Naturalists' Club wrote to the responsible minister and requested the government purchase the site and establish a tropical studies center. The Club pointed out that the Mitchell Plateau was an important location offering a diversity of habitats, an all-weather airstrip and had access to the sea at Port Warrender. The government considered the request but due to what it then described as "serious financial hurdles" no action was taken and the opportunity was lost (Harris 1983a). In December 1983, the present author again raised the need for a research facility in the Kimberley to help build up a continental perspective of Australia's rainforests (Harris 1983b). Again, no action was forthcoming. There is a serious need for a tropical research center in the northwest Kimberley to be established so that scientists from a range of disciplines and institutions can undertake long-term research projects in partnership with Traditional Owners.

\section{ACKNOWLEDGMENTS}

I would particularly like to acknowledge and thank the following people for their assistance, guidance and advice in the preparation of this paper.

The Aboriginal Traditional Owners of the Kimberley who have been extremely generous over many decades in conducting me through country and sharing their vast wisdom, knowledge, culture and beliefs that has allowed me to have a far greater appreciation of this ancient landscape.

Professor Ric How (former Curator of Biogeography, Western Australian Museum) for his invaluable discussions, comments and advice on the fauna of the Kimberley and for providing faunal images; Vince Kessner for his devotion and zeal to Kimberley snail collecting and providing outstanding snail images; Ron Johnstone (Curator of Ornithology, Western Australian Museum) for advice on the avifauna of rainforests and access to images; Norm McKenzie AM (former Senior Principal Research Scientist, Department of Parks and Wildlife) for sharing his encyclopedic knowledge of Kimberley rainforests; John Dell PSM, for reviewing the manuscript and making valuable comments; Matt Barrett (Kings Park and Botanic Garden) and Russell Barrett (National Herbarium of New South Wales, Royal Botanic Gardens and Domain Trust, Sydney), the former for advice on rainforest fungi and the latter for an image of Hibiscus peralbus; Tom Vigilante (Bush Heritage, Australia), for reviewing the manuscript and making valuable comments; PhD researcher Stefania Ondei, University of Tasmania, for providing papers of her recent studies on Kimberley rainforests; Alex George AM, Murdoch University, for reviewing and commenting on the paper and Frank Köhler, Australian Museum, for advice and research papers on the biogeography of rainforest snails. Additional images were kindly provided by Brian Carter, Jiri Lochman (Lochman Transparencies) and Tim Willing.

I thank John Huisman (Curator) and staff of the Western Australian Herbarium for access to the plant collections housed there; my colleagues (past and present) at the Western Australian Museum for their advice, 
discussions and good company over many fieldtrips to the Kimberley and Karl-Heinz Wyrwoll (Senior Research Fellow, University of Western Australia) for advice on the climatic history of the Kimberley. I am indebted to Bernie Hyland (former rain forest botanist with Australian National Herbarium, CSIRO) for his willingness to share with me his vast knowledge of rainforest plants on Kimberley field trips as well as paying homage to his mastery of the brush-hook in creating ready access into rainforest patches. I also acknowledge his foresight in developing "Australian Tropical Rain Forest Plants," an interactive identification and information system which covers all the trees, shrubs and vines across northern Australia's rain forests.

I am also extremely indebted to my friends at Biota Environmental Sciences, particularly Paul Sawers (GIS/Spatial Data Manager) for his cartographic skills in producing several of the figures and maps that appear in this paper and Michi Maier (Principal Botanist/Director), for reviewing the manuscript and making valuable comments. Mike Donaldson (Wildrock Publications) kindly gave permission to reproduce his geology map of the Kimberley.

The paper has furthermore improved considerably because of suggestions from Professor Jeremy RussellSmith and another anonymous reviewer. I am extremely grateful for the support and encouragement I have received from Barney L. Lipscomb, Editor-in-Chief, Botanical Research Institute of Texas (BRIT). I thank my wife Irene Ioannakis for her patience and assistance in putting this paper together. I would like to sincerely thank Biota Environmental Sciences, Western Australian Naturalists' Club, and Western Australian Gould League at Herdsman Lake Wildlife Centre for financial support of this publication.

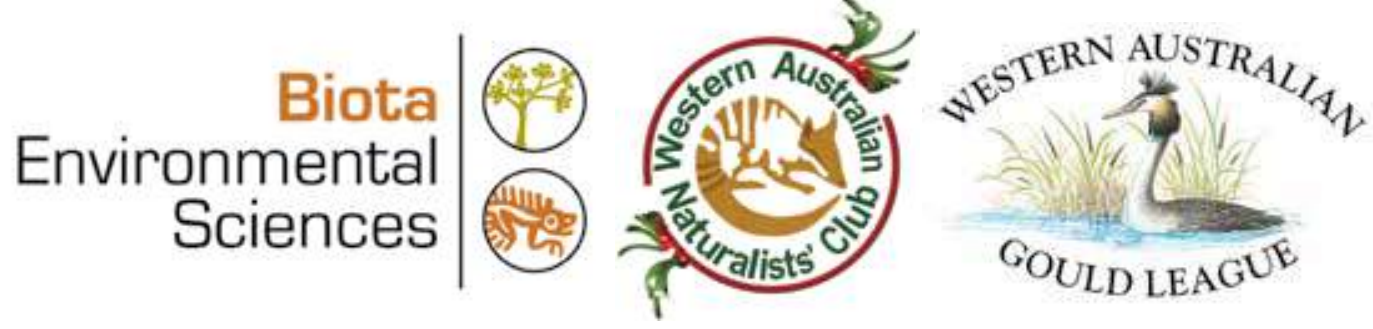

REFERENCES

Allen, A.D. 1966. Geology of the Montague Sound 1:250,000 area (SD/51-12), Western Australia. Bureau of Mineral resources, Australian Record 1966/20.

AlLen, A.D. 1971. Explanatory notes of the Montague Sound geological sheet area. Bureau of Mineral resources, Canberra.

Amax Exploration Company. nd. Report on evaluation of the Cape Bougainville area. Unpublished report.

Australian Government. 1999. Environment Protection and Biodiversity Conservation Act 1999 (EPBC Act). Department of Environment and Heritage. Canberra, ACT, Australia.

AustRALIAN Government. 2012a. Background: Threat abatement plan to reduce the impacts on northern Australia's biodiversity by the five listed grasses: Department of Sustainability, Environment, Water, Population and Communities, Canberra, ACT, Australia.

Australian Government. 2012b. West Kimberley National Heritage Place. A draft guide for landholders. Department of Sustainability, Environment, Water, Population and Communities, Canberra, ACT, Australia.

Australian Government. 2015a. Our North, Our Future; White Paper on developing Northern Australia, Canberra, ACT, Australia.

Australian Government. 2015b. Emissions reduction fund method: Savannah fire management. Department of Environment, Canberra, ACT, Australia. (http://environment.gov.au/emission-reduction-fuel).

Australian Government. 2017. Aristolochia fact sheet. Department of Health. Therapeutic Goods Administration, Canberra, $A C T$, Australia.

Baccini, A., W. Walker, L. Carvalho, M. Farina, D. Sulla-Menashe, \& R.A. Houghton. 2017. Tropical forests are a net carbon source on above ground measurements of gain and loss. Science 357:Issue (6358). doi.10.1126/science.aam5962.

BALME, J. 2000. Excavations revealing 40,000 years of occupation at Mimbi caves, south central Kimberley, Western Australia. Austral. Archaeol. 5(1):1-5. http://dx.doi.org/10.1080/03122417.2000.11681674 
Barlow, B.A. \& B.P.M. Hyland. 1988. The origins of the flora of Australia's wet tropics. In: R. Kitching ed. Ecology of Australia's wet tropics. Proc. Ecol. Soc. Austral. 15:1-17.

BARRETT, R.L. 2015. Fifty new species of vascular plants from Western Australia-celebrating fifty years of the Western Australian Botanic Garden at Kings Park. Nuytsia 26:3-20.

Beames, L. 2013. Valuable \& threatened, monsoon vine thickets of the Dampier Peninsula. A summary of key findings. Environs Kimberley West Kimberley Nature Project 2011-2013. Environs Kimberley, Broome, Australia.

BeARD, J.S. \& K.F. KenNeally. 1993. Dry coastal ecosystems of Northern Australia. In: E. Van der Maarel, ed. Ecosystems of the World 2B. Dry Coastal Ecosystems: Africa, America, Asia and Oceania. Amsterdam, Elsevier, Netherlands. Pp. 239-258.

BEARD, J.S. 1976. The monsoon forests of the Admiralty Gulf, Western Australia. Vegetatio 31:177-92.

BEARD, J.S. 1979. The vegetation of the Kimberley area. Explanatory notes to map sheet 1 of Vegetation Survey of Western Australia: Kimberley. University of Western Australia Press (UWAP), Nedlands, Australia.

Beard, J.S., K.A. Clayton-Green, \& K.F. Kenneally. 1984. Notes on the vegetation of the Bougainville Peninsula, Osborn and Institute Islands, Northern Kimberley District, Western Australia. Vegetatio 57:3-13.

Belfield, E., L. Beames, \& S. Black. 2013. Valuable \& threatened, monsoon vine thickets of the Dampier Peninsula. A summary of key findings from the Broome Botanical Society. Environs Kimberley, Broome, Australia.

Black, S.J., T. Willing, \& D. DuREAu. 2010. A comprehensive survey of the flora, extent and condition of vine thickets on coastal sand dunes of Dampier Peninsula, West Kimberley 2000-2002. Unpublished report Broome Botanical Society. (www.environskimberley.org.au/wp-content/uploads/2013/01/Vine-Thicket-Report-20-sept-2010_publicversion2.pdf). Accessed December 2016.

BoWmAN, D.M.J.S. \& J.C.Z. WoINARSKI. 1994. Australian monsoon rainforest mammals: Implications for the conservation of rainforest animals. Pacific Cons. Biol. 1(2):98-106.

BowmAn, D.M.J.S., B.A. WILSON, \& L. MCDONOUGH. 1991. Monsoon forests in north Western Australia 1. Vegetation classification and the environmental control of tree species. J. Biogeogr. 18:679-686.

Bradley, A.J., C.M. Kemper, D.J. KitcheneR, W.F. Humphreys, \& R.A. How. 1987. Small mammals of the Mitchell Plateau Region, Kimberley, Western Australia. Austral. Wildlife Res. 14:397-413.

BRADSTOCK, R.A. 2008. Effects of large fires on biodiversity in south-eastern Australia: Disaster or template for diversity. Int. J. Wildland Fire 17:809-22.

BrockmAN, J.G. 1880. Journal of an exploring trip from Beagle Bay to the Fitzroy River and back again. The West Australian, 28 May, 1880.

BurbidGE, A.A. \& N.L. McKenzIE. 1978. The Islands of the north-west Kimberley. Wildl. Res. Bull. Western Australia 7:1-47.

Burbidge, A.A., N.L. Mckenzie, K.E.C. Brennan, J.C.Z. Woinarski, C.R. Dickman, A. Baynes, G. Gordon, P.W. MenkHorst, \& A.C. Robinson. 2008. Conservation status and biogeography of Australia's terrestrial mammals. Austral. J. Zool. 56:411-422.

Bureau of Meteorology (BOM). 2016. Available http://www.bom.gov.au (accessed December 2016).

BYRNE, M. 2008. Birth of a biome: Insights into the assembly and maintenance of the Australian arid zone biota. Molec. Ecol. 17:4398-4417.

Carwardine, J., T. O'connor, S. LegGe, B. Mackey, H.P. Possingham, \& T.G. Martin. 2011. Priority threat management to protect Kimberley wildlife. CSIRO Ecosystem Sciences, Brisbane, Australia.

ChappeLL, J. \& B.G. Thom. 1977. Sea levels and coasts. In: Allen, J., Godson, J., Jones, R. eds. Sunda and Sahul: Prehistoric studies in south-east Asia, Melanesia and Australia. Academic Press, London, U.K. Pp. 275-291.

CHRISTIAN, C.S. \& G.A. SteWART. 1953. General report on a survey of Katherine-Darwin region, 1946. CSIRO Austral. Land Res. Ser. No. 1. Melbourne, Australia.

CLARKSON, J.R. \& K.F. KENNEALLY. 1988. The floras of Cape York and the Kimberley: A preliminary comparative analysis. Proc. Ecol. Soc. Australia 15:259-66.

Clayton-Green, K.A. \& J.S. BeARD. 1985. The fire factor in vine thicket and woodland vegetation of the Admiralty Gulf region, north-west Kimberley, Western Australia. In: M.G. Ridpath \& L.K. Corbett. eds. Ecology of the wet-dry tropics. Ecological Society of Australia.

Coluns, B. 2012. The mysteries and magic of fog in Broome. ABC Kimberley, Western Australia.

ComRIE-Greig, J. \& L. AbDo. EDs. 2014. Ecological studies of the Bonaparte Archipelago and Browse Basin. INPEX Operations Australia Pty Ltd. Perth, Western Australia.

Commonwealth Of Australia Gazette. 2011. Inclusion of a place in the National Heritage List. The West Kimberley. No. S132, Wednesday, 31 August.

Convention On Biological Diversity. 1993. Article 8j Traditional knowledge, innovations and practices. United Nations, Geneva. https://www.cbd.int/undb/media/factsheets/undb-factsheet-cbd-en.pdf (Accessed 10 February 2017) 
CoWIE, R.H. \& B.S. HolLAND. 2006. Dispersal is fundamental to biogeography and the evolution of biodiversity on oceanic islands. J. Biogeogr. 33(2):193-198.

CRAWFORD, I.M. 1982. Traditional Aboriginal plant resources in the Kalumburu area: Aspects in ethno-economics. Rec. W. Austral. Mus. Suppl. No. 15.

CRISP, M., L. Cook, \& D. TEAne. 2004. Radiation of the Australian flora: What can comparisons of molecular phylogenies across multiple taxa tell us about the evolution of diversity in present-day communities? Philos. Trans. Royal Soc. B: Biol. Sci. 359:1551-1571.

DAVIS, L.D. 1984. The fragmented forest. Island biogeography theory and the preservation of biotic diversity. The University of Chicago Press, Chicago, U.S.A.

Denniston, R.F., K-H. Wyrwoll, V.J. Polyak, J.R. Brown, Y. Asmerom, A.D. Wanamaker. Z. Lapointe, R. Ellerbroek, M. Bathelmes, D. Cleary, J. Cugley, D. Woods, \& W.F. Humphreys. 2013b. A Stalagmite record of Holocene Indonesian-Australian summer monsoon variability from the Australian tropics. Quat. Sci. Rev. 78:155-168.

Denniston, R.F., G. Villarini, A.N. Gonzales, K-H. Wyrwoll, V.J. Polyak, C.C. Ummenhofer, M.S. Lachniet, A.D. Wanamaker, W.F. HumphreYs, D. Woods, \& J. Cugley. 2015. Extreme rainfall activity in the Australian tropics reflects changes in the El Nino/ Southern Oscillation over the last two millennia. Proc. Natl. Acad. Sci. 112(15):4576-4581.

Department Of Parks And Wildlife, Western Australia. 2014. Cane toad strategy for Western Australia 2014-2019. Perth, Western Australia.

Department Of Parks And Wildife. 2014. Kimberley science and conservation strategy. Key achievements of the landscape conservation initiative. Government of Western Australia, Perth, Western Australia.

Department Of The Environment. 2015. Australia's 15 National Biodiversity Hotspots. Australian Government, Canberra, Australia.

Department Of Water And Environmental Regulation. 2017. Groundwater-dependent ecosystems of the Dampier Peninsula. Environm. Water Rep. Ser. Rep. 29 (August 2017).

DIAMOND, J.M. 1976. Island biogeography and conservation: Strategy and limitations. Science (New Series) 193:1027-1029.

Dixon, K.W. 2002. Orchids of Kimberley. Boab Bull. 48:4-5. Kimberley Society, Perth, Western Australia.

DonALDSON, M. 2012. Kimberley rock art - Volume 1: Mitchell Plateau area. Wildrock Publications, Perth, Western Australia.

EAston, W.R. 1923. Report on north Kimberley District of Western Australia. Department of the Northwest Publication 3. Perth, Western Australia.

Environmental Protection Authority, Western Australia. 2001. Guidance for the assessment of environmental factors. Guidance statement for protection of tropical arid zone mangroves along the Pilbara coastline. No.1, Perth, Western Australia.

Fisher, J., L. Beames, Bardi Jawi Rangers, Nyul Nyul Rangers, J. Majer, \& B. Heterick. 2014. Using ants to monitor changes within and surrounding endangered monsoon vine thickets of the tropical Dampier Peninsula, north Western Australia. Forest Ecol. Managem. 318:78-90.

FLoYd, A.G. 1990. Australian rainforests in New South Wales. Surrey Beatty and Sons, Sydney, Australia.

Fryxell, P.A. 1987. Three new species (from Australia and Venezuela) and three new names (of Mexican plants) in the Malvaceae. Syst. Bot. 12(2):274-80.

GaRdner, C.A. 1923. Botanical notes, Kimberley Division of Western Australia, Kimberley exploring expedition 1921. Bull. W. Australia For. Dept. 32:1-105.

Gardner, C.A. 1944. The vegetation of Western Australia. Presidential Address. J. Roy. Soc. W. Australia 28:11-87.

GeORGE, A.S. 1999. William Dampier in New Holland: Australia's first natural historian. Blooming Books Pty Ltd, Hawthorn, Victoria.

Gibson, L.A., S. YATES, \& P. Doughty. EDS. 2014. Biodiversity values on selected Kimberley Islands, Australia. Rec. W. Australia Mus. Suppl. 81.

Giesen, W., S. Wulffraat, M. Zieren, \& L. Scholten. 2007. Mangrove guidebook for Southeast Asia. FAO \& Wetlands International, 2006. Printed by Dharmasarn Co., Ltd., Thailand.

Grainger, A. 1980. The state of the world's tropical forests. Ecologist 10:6-54.

Grant-RICHARDS, E. 1906. Dampier's voyages by Captain William Dampier. Vol. 1. E. Grant-Richards, London, U.K.

Harrington, M.G., B.R. Jackes, M.D. Barrett, L.A. Craven, \& R.L. Barrett. 2012. Phylogenetic revision of Backhousieae (Myrtaceae): Neogene divergence, a revised circumscription of Backhousia and two new species. Austral. Syst. Bot. 25(6):404-417.

HARRIS, A. 1983a. Tropical centre needed. The West Australian; Saturday October 1, p.13. 
HARRIS, A. 1983b. Scientists want rain-forest centre. The West Australian. Monday December 19, p.66.

HILL, E. 1933. The legion of the lost ones. Chronical (Adelaide, SA) 29 June, p. 57.

HILL, G. 1911. Field notes on the birds of the Kimberley, north-west Australia. Emu 10:258-90.

Hnatiuk, R.J. \& K.F. Kenneally. 1981. A survey of the vegetation and flora of Mitchell Plateau and Admiralty Gulf. In: Biological Survey of Mitchell Plateau and Admiralty Gulf, Kimberley, Western Australia. W. Austral. Mus. Special Publ. Perth.

HOOKER, J.D. 1860. Introductory essay. Flora Tasmaniae. Vol.1, Lovell Reeve, London, U.K.

Hyland, B.P.M., T. Whifin, D.C. CRistophel, B. Gray, \& R.W. Elick. 2003. Australian tropical rain forest plants-trees, shrubs and vines. CSIRO Publishing, Collingwood, Victoria, Australia.

JACKSON, W. 2017. Five-yearly environmental stocktake highlights the conflict between economy and nature. The Conversation. March 7, 2017. (https://theconversation.com/five-yearly-environmental-stocktake-highlights-theconflict-between-economy-and-nature-73964?utm_medium=email\&utm_campaign). Accessed 7 March 2017.

$\mathrm{J}_{\mathrm{ACOB}}$ A. 2014. Biodiversity surveys assist Kimberley land management. Government Media Statements. Monday

27, October 2014. (https://www.mediastatements.wa.gov.au/Pages/Barnett/2014/10/Biodiversity-surveys-assistKimberley-land-management-.aspx). Accessed 20 August 2016.

JENNINGS, J.N. 1975. Desert dunes and estuarine fill in the Fitzroy estuary (North Western Australia). Catena 2 (C):215-262.

Johnstone, R.E. 1981. Notes on the distribution, ecology and taxonomy of the red-crowned pigeon (Ptilinopus regina) and Torres Strait Pigeon (Ducula bicolor) in Western Australia. Rec. W. Australia Mus. 9(1):7-22.

JONES, N. 2016. Kimberley seed bank: Traditional knowledge used to protect biodiversity. ABC News. First posted Sunday 27 March 2016.

KabAy, E.D. \& A.A. BuRbidge. eds. 1977. A biological survey of the Drysdale National Park, North Kimberley, Western Australia. Wildlife Res. Bull. 6:1-133.

Karadada, J., L. Karada, W. Goonak, C. Mangolamara, W. Bunjuck, B. Duanghara, S. Mangolomara, J. Oobagooma, A. Charles, D. Williams, R. Karadada, T. Saunders, \& G. Whitman. 2011. Uunguu plants and animals: Aboriginal biological knowledge from Wunambal Gaambera country in the north-west Kimberley, Australia. Wunambal Gaambera Aboriginal Corporation, Wyndham, Western Australia.

KeEnAn, T.D., B.R. Morton, M.J. Manton, \& G.J. Holland. 1989. The Island thunderstorm experiment (ITEX) - a study of tropical thunderstorms in the maritime continent. Bull. Amer. Meteorol. Soc. 7:152-159.

Keenan, T.D., S.A. Rutledge, R.E. Carbone, J.W. Wilson, T. Takahashi, M.W. Moncrieff, G.J. Holland, N.J. Tapper, C.M.R. Platt, J.M. HACKER, K. SAITO, \& T. CROOK. 2000. The maritime continent thunderstorm experiment [MCTEX]: Overview and some results. Bull. Amer. Meteorol. Soc. 81(10):2433-2455.

Keane, R.E., J.K. Agee, P. Fule, J.E, Keely, C. Key, S.G. Kitchen, R. Miller, \& L.A. Schulte. 2008. Ecological effects of large fires on US landscapes: Benefit or catastrophe? Int. J. Wildland Fire 17:696-712.

KEIGHERY, G.J. 2014. Protecting our Kimberley's unique flora. Landscope 29(4):9-13.

KEIGHERY, G.J. 2015. Weeding out Kimberley weeds. Landscope 31(1):41-45.

KENDRICK, P.G. \& J.K. RolfE. 1991. The reptiles and amphibians of Kimberley rainforest. In: McKenzie, N.L., Johnston, R.B., Kendrick, P.G. eds. Kimberley Rainforests of Australia. Surrey Beatty \& Sons Pty Ltd., Australia. Pp. 347-59.

KenneAlly, K.F. 1983. Kalenchoe crenata (Andr.) Haw (Crassulaceae) a new record for Australia. Austral. Syst. Bot. Soc. Newslett. 34:4-5.

Kenneally, K.F., D. Edinger, K. Coate, B. Hyland, R. How, L. Schmitt, M. Cowan, T. Willing, \& C. Done. 2003. The last great wilderness-Exploring the Mitchell Plateau 2002. Landscope Expeditions Report No. 49, Western Australian Department of Conservation and Land Management, Perth.

Kenneally, K.F., D.C. Edinger, \& T. Willing. 1986. Broome and Beyond. Plants and people of the Dampier Peninsula, Kimberley, Western Australia. Western Australian Department of Conservation and Land Management, Perth.

Kenneally, K.F., G.J. KeigherY, \& B.P.M. HyLAND. 1991. Floristics and phytogeography of Kimberley rainforests, Western Australia. In: McKenzie, N.L., Johnston, R.B., Kendrick, P.G. eds. Kimberley Rainforests of Australia. Surrey Beatty \& Sons Pty Ltd., Australia.

Kenneally, K.F. \& N.L. MckenZiE. 1991. Companion to Kimberley rainforest Australia. Surrey Beatty \& Sons Pty Ltd., Australia. KERINS, S. 2016. Kimberley conservation threatens to take a step back on indigenous rights. Austral. Environm. Rev. Aug 186-189.

KERSHAW, A.P. 1988. The late Cainozoic history of Australasia: 20 million to 20 thousand years B.P. In: Huntly, B. and T. Webb eds. Vegetation History. Kluwer, Dordrecht, Netherlands. Pp. 237-301. 
KING, P.P. 1827. Narrative of a survey of the intertropical and western coast performed between the years 1818 and 1822. Volumes 1 \& 2. John Murray, London, U.K.

KINNAIRD, M. 2000. Big on figs (https://www.nwf.org/News-and-magazines/NationalWildlife/Animals/Archive/2000Bigon-Figs.aspx) Accessed December 2016.

KöHLER, F. 2011. Biodiversity hotspot and treasures of the Kimberley. Australian Museum, Sydney (https://australianmuseum.net.au/featured-project-treasures-of-the-kimberley).

KöHLeR, F. \& F. CRISCIONE. 2013. Plio-Pleistocene out-of-Australia dispersal in a camaenid land snail. J. Biogeogr. 40:1971-1982.

KöHLER, F. \& F. CRISCIONE. 2014. Molecular phylogenetics and comparative anatomy of Kimberleytrachia Köhler, 2011a genus of land snails endemic to the coastal Kimberley, Western Australia with description of new taxa (Gastropoda, Camaenidae). Contr. Zool. 83(4):245-267.

LAURIE, V. 2010. The Kimberley. Australia's last great wilderness. UWA Publishing; Crawley.

LethLEAN, J. 2017. Best of the bush. The Australian. February 14, p. 16. (https://www.the australian.com.au/life). Accessed 14 February 2017.

MaCarthuR, R.H. \& E.O. Wilson. 1967. The theory of island biogeography. Princeton University Press, New Haven, Connecticut, U.S.A.

MangglamarRa, G., A.A. Burbidge, \& P.J. Fuller. 1991. Wunumbal words for rainforest and other Kimberley plants and animals. In: McKenzie, N.L., Johnston, R.B., Kendrick, P.G. eds. Kimberley Rainforests of Australia. Surrey Beatty \& Sons Pty Ltd., Australia. Pp. 413-21.

Mckenzie, N.L., A.A. Burbidge, A. Baynes, R. Breeton, C.R. Dickman, L.A. Gibson, G. Gordon, R.W. Menkhorst, A.C. Robinson, M.R. WILLAMS, \& J.C.Z. WoINARSKI. 2007. Analysis of factors implicated in the recent decline of Australia's mammalian fauna. J. Biogeogr. 34:597-611.

McKenzie, N.L. \& K.F. Kenneally. 1983. Wildlife of the Dampier Peninsula, Part 1, Background and Environment. Wildl. Res. Bull. W. Austral. No.11:5-23.

McKenZIE, N.L., R.B. Johnston, \& P.G. KendRICK. EDS. 1991. Kimberley Rainforest of Australia. Surrey Beatty \& Sons Pty Ltd., Australia.

McKenzie, N.L., A.N. Start, A.A. Burbidge, K.F. Kenneally, \& N.D. Burrows. 2009. Protecting the Kimberley. A synthesis of scientific knowledge to support conservation management in the Kimberley region of Western Australia. Part B: Terrestrial Environments. Department of Environment and Conservation, Western Australia.

MACPHAlL, M.K. 2007. Australian palaeoclimates: Cretaceous to Tertiary. A review of palaeobotanical and related evidence to the year 2000. CRC LEME Special Volume Open File Report 151, Bentley, Western Australia.

MEDHI, D.M. \& B.S. BHAU. 2013. The genus Zanthoxylum-A stockpile of biological and ethnomedicinal properties. Open Access Sci. Rep. 2(3):1-8. (http.//dx.doi.org/10.4172/scientific reports697).

MiLES, J.M. \& A.A. BuRBIDGE. EDS. 1975. A biological survey of the Prince Regent reserve, North-West Kimberley, Western Australia. Wildl. Res. Bull. Western Australia 3:1-114

MILLS, V. 2015. Favourite Kimberley bush foods and medicine targeted by bio-pirate. ABC Kimberley; Broome: 5 February. Naumann, I.D., T.A. WeiR, \& E.D. Edwards. 1991. Insects of Kimberley rainforests. In: McKenzie, N.L., Johnston, R.B., Kendrick, P.G. eds. Kimberley Rainforests of Australia. Surrey Beatty \& Sons Pty Ltd., Australia. Pp. 299-332.

NIX, H. 1982. Environmental determinants of biogeography and evolution in Terra Australis. In: Barker, W.R. \& P.J.M. Greenslade. Evolution of the flora and fauna of arid Australia. Peacock Press, Frewville, South Australia. Pp. 47-66.

Онва, H. 2003. Taxonomic studies on the Asian species of the genus Kalanchoe (Crassulaceae) 1. Kalanchoe spathulata and its allied species. Jap. J. Bot. 78:247-256.

O'CONNOR, S. \& P. VETH. 2006. Revisiting the past: Changing interpretations of Pleistocene settlement subsistence and demography in northern Australia. In: I. Lilley, ed. Archaeology of Oceania: Australia and the Pacific Islands. Blackwell, Oxford, U.K. Pp. 31-47.

O'CONNOR, S. 1995. Carpenters Gap Rockshelter1:40,000 years of Aboriginal occupation in the Napier Ranges, Kimberley, WA. Austral. Archaeol. 40:58-59.

OndeI, S., L.D. PrioR, T. VIGILANTE, \& D.M.J.S. Bowman. 2016a. Post-fire resprouting strategies of rainforest and savanna saplings along the rainforest-savanna boundary in the Australian monsoon tropics. PI. Ecol. 217:711-724.

ONDEl, S., L.D. PrIOR, G.J. WILLIAMson, \&T. VIGILANTE. 2016b. Water, land, fire and forest: Multi-scale determinants of rainforests in the Australian monsoon tropics. In: Ecology \& Evolution. John Wiley \& Sons Ltd., London, U.K.

ONDEI, S., L.D. PRIOR, T. VIGILANTE, \& D.M.J.S. BowmAn. 2017. Fire and cattle disturbance affects vegetation structure and rain forest expansion into savanna in the Australian monsoon tropics. J. Biogeogr. 44(10):2331-2342. 
Ouzman, S., P. Veth, C. Myers, P. Heaney, \& K. Kenneally. 2017. Plants before animals?: Aboriginal rock art as evidence of ecoscaping in Australia's Kimberley. In: David, B. \& I. McNiven. The Oxford handbook of the archaeology and anthropology of rock art. Oxford University Press, Oxford, UK. (10.1093/oxfordhb/9780190607357.013.31).

PEPPER, M. \& J.S. KEOGH. 2014. Biogeography of the Kimberley, Western Australia: A review of landscape evolution and biotic response in an ancient refugium. J. Biogeogr. 41(8):1443-1455.

PoweLL, R. \& L. Murdoch. 2010. Patent erupts over Kakadu plum. The Sydney Morning Herald. Dec. 4, 2010.

PRICE, O.F., J.C.Z WoINARSKI, \& D. ROBINSON. 1999. Very large area requirements for frugivorous birds in monsoon rainforests of the Northern Territory, Austral. Biol. Cons. 91:169-80.

Proske, U., D. Heslop, \& S. Haberle. 2014. A Holocene record of coastal landscape dynamics in the eastern Kimberley region, Australia. J. Quat. Sci. 29(2):163-174.

Radford, I. C., Thomson-Dans, R. Fairman, \& E. Hatherley. 2013. Kimberley mammals bouncing back. Landscope 28(3):32-38.

RICHARDS, P.W. 1952. The tropical rainforest: An ecological study. Cambridge University Press, London.

RoBinson, D. \& M. RAven. 2016. Identifying and preventing biopiracy in Australia: Patent trends for plants with Aboriginal uses. Austral. Geog. Pp. 1-21. Published online 20 Sep 2016. http://dx.dol.org/10.1080/00049182.2016.1229240 accessed 9 Feb 2017.

RusSELL-SMith, J. \& D.M.J.S. Bowman 1992a. Conservation of monsoon rainforest isolates in the Northern Territory, Austral. Biol. Cons. 59:51-63.

Russel-Smith, J., G.D. Cook, P.M. Cooke, A.C. EdWARds, M. LendRum, C.P. Meyer, \& P.J. WhiteheAd. 2013. Managing fire regimes in north Australia savannas: Applying Aboriginal approaches to contemporary global problems. Front. Ecol. Environ. (online issue 1):e55-e63, (http://dx.doi.org/10.1890/120251)

Russel-Smith, J. \& A.H. LeE. 1992b. Plant populations and monsoon rain forest in the Northern Territory. Biotropica 24(4):471-487.

RuSSELL-SMith, J., N.L. MCKENZIE, \& J.C.Z. WoInARSKI. 1992c. Conserving vulnerable habitat in northern and north-western Australia: The rainforest archipelago. In: Moffatt, I. \& A. Webb, eds. Conservation and development issues in north Australia. Australian National University, North Australia Research Unit workshop, Darwin, September 1991.

Russel-Smith, J., B.P. Murphy, C.P. Meyer, G.D. Cook, J. Maier, A.C. Edwards, J. Schatz, \& P. Brocklehurst. 2009. Improving estimates of savanna burning emissions for greenhouse accounting in northern Australia: limitations, challenges, applications. Int. J. Wildland Fire 18(1):1-18 (http://doi.org/10.1071/WF08009)

RusselL-SMith, J. \& P. StANTON. 2002. Fire regimes and fire management of rainforest communities across northern Australia. In: Bradstock, R.A., J.E. Williams \& A.M. Gill. Flammable Australia: The fire regimes and biodiversity of a continent. Cambridge University Press, Cambridge, UK. Pp. 239-350.

SCHIMPER, A.F.W. 1903. Plant-geography upon a physiological basis. Trans. By W.R. Fisher. Revised \& edited by P. Groom \& I.B. Balfour. Clarendon Press, Oxford, U.K.

Shanahan, M., S. So, S. G. Compton, \& R. Corlett. 2001. Fig-eating by vertebrate frugivores: A global review. Biol. Rev. Cambridge Philos. Soc. 76(4):529-572.

Shanyengana, E.S., J.T. Henschel, M.K. Seely, \& R.D. Sanderson. 2002. Exploring fog as a supplementary water sources in Namibia. Atmos. Res. 64:251-259.

SLATER, C. 2003. In search of the rain forest. Duke University Press, Durham, North Carolina, U.S.A.

SNIDERMAN, J.M.K. \& G.J. JORDAN. 2011. Extent and timing of floristic exchange between Australian and Asian rain forests. J. Biogeogr. 38:1445-1455.

SPECK, N.H. 1960. Vegetation of the North Kimberley area, Western Australia. CSIRO Austral. Land Res. Ser. 4:41-63.

STOUTJESDIK, P. 2013. Plant genetic resources for food and agriculture: Second national report-Australia, Technical Report 13.11. Canberra, December. CC BY 3.0. 2013. Tropical Forests (http://www4,vwep.edu/geo/faculty/ritter/geog101/ textbooks/biomes/biomes_tropical_forests_page_1.html). Accessed December 2016.

SuppIAH, R. 1992. The Australian summer monsoon: A review. Prog. Phys. Geogr. 16(3):283-318.

THOM, B.G., L.D. WRIGHT, \& J.M. Coleman. 1975. Mangrove ecology and deltaic estuarine geomorphology: Cambridge GulfOrd River, Western Austral. J. Ecol. 63(1):203-232.

TRUSWELL, E.M. \& W.K. HARRIS. 1982. The Cainozoic palaeobotanical record in arid Australia: Fossil evidence for the origin of an arid adapted flora. In: Barker, W.R. \& P.J.M. Greenslade, Evolution of the fauna and flora of arid Australia. Peacock, Frewville, South Australia. Pp.67-76.

TRUSWELL, E.M. 1993. Vegetation changes in the Australian Tertiary in response to climatic and phytogeographic forcing factors. Austral. Syst. Bot. 6:533-557. 
TYLER, I.M., R.M. HoCKING, \& P.W. HAINES. 2012. Geological evolution of the Kimberley region of Western Australia. Episodes. J. Int. Geosci. 35:298-306.

Van Damme, P. 1991. Plant ecology of the Namib Desert. Africa Focus 4:355-400.

Veth, P., C. Myers, P. Heaney, \& S. Ouzman. 2016. Plants before farming: The deep history of plant-use and representation in the rock art of Australia's Kimberley region. Quatern. Int. 30:1-20.

Vigilante, T., J. Toohey, A. Gorring, V. Blundell, T. Saunders, S. Mangolamara, K. George, J. Oobagooma, M. Waina, K. Morgan, \& K. DoOHAN. 2014. Island country: Aboriginal connections, values and knowledge of the Western Australian Kimberley islands in the context of an island biological survey. In: Gibson, L.A., Yates, S., Doughty, P., eds. Biodiversity values on selected Kimberley Islands, Australia. Rec. W. Austral. Mus., Suppl. 81:2012-2014.

Vigilante, T., S. Ondei, C. Goonak, D. Williams, P. Young, \& D.M.J.S. Bowman. 2017. Collaborative research on the ecology and management of the 'Wulo' monsoon rainforest in Wunambul Gaambera country, North Kimberley, Australia. Land 6(4)68:1-20. doi: 10.3390/land6040068.

Vogel, E., C. Meyer, \& R. Eckard. 2017. Severe heatwaves show the need to adapt livestock management for climate. The Conversation. (https://theconversation.com/severe-heatwaves-show-the-need-to-adapt-livestock-managementfor-climate-73447?utm) Accessed 28 February 2017.

WarRen, J.M., D.Z. EmAmdie, \& D.Z. Kalal. 1997. Reproductive allocation and pollinator distribution in cauliflorous trees in Trinidad. J. Trop. Ecol. 3:337-345.

WATTS, J. 2017. Alarm as study reveals world's tropical forests are huge carbon emission source. The Guardian, Friday 29 September 2017. https://www.theguardian.com/environment/2017/sep/28.

WeBB, L.J. \& J.G. TraceY. 1981. Australian Rain forests: Pattern of change. In: A. Keast, ed. Ecological biogeography of Australia. Junk bv Publishers, The Hague, Netherlands. Pp. 605-94.

WEBB, L.J. 1959. A physiognomic classification of Australian rainforests. J. Ecol. 47:551-70.

Western Australian Museum. 1981. Biological Survey of Mitchell Plateau and Admiralty Gulf, Kimberley, Western Australia. W. Austral. Mus. Special Publ. Perth, Western Australia.

WhitMore, T.C. 1984. Tropical rainforests of the Far East. Clarendon Press, Oxford, U.K.

Zimmermann, F. 2011. The jungle and the aroma of meats: An ecological theme in Hindu medicine. Motilal Barnarsidass, Delhi, India. 